\title{
Interventions to improve water quality for preventing diarrhoea (Review)
}

\author{
Clasen TF, Roberts IG, Rabie T, Schmidt WP, Cairncross S
}

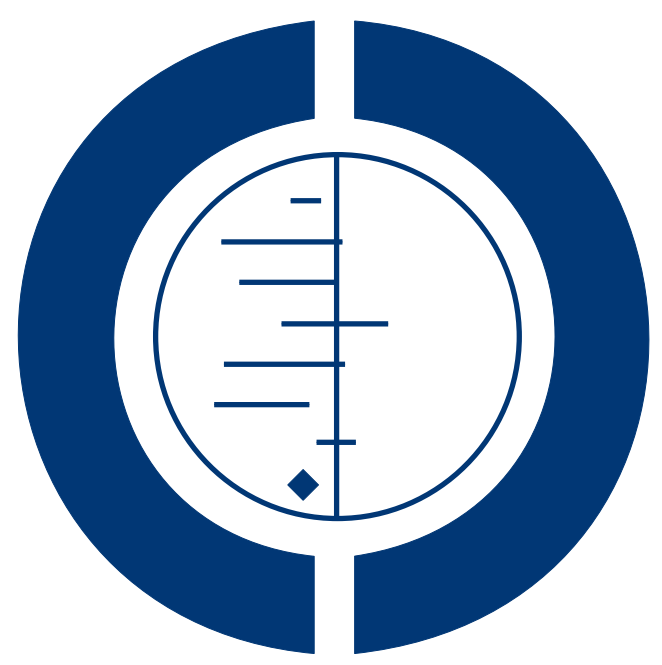

\section{THE COCHRANE COLLABORATION $^{\circledR}$}

This is a reprint of a Cochrane review, prepared and maintained by The Cochrane Collaboration and published in The Cochrane Library 2006, Issue 3

http://www.thecochranelibrary.com

\section{WILEY}

Interventions to improve water quality for preventing diarrhoea (Review)

Copyright @ 2009 The Cochrane Collaboration. Published by John Wiley \& Sons, Ltd. 
TABLE OF CONTENTS

HEADER . . . . . . . . . . . . . . . . . . . . . . . . . . . . . . . . . . . . . . . . . . . . . . . . .

ABSTRACT . . . . . . . . . . . . . . . . . . . . . . . . . . . . . . . . . . . . . . . . . . . . . . . . 1

PLAIN LANGUAGE SUMMARY . . . . . . . . . . . . . . . . . . . . . . . . . . . . . . . . . . . . . 2

BACKGROUND . . . . . . . . . . . . . . . . . . . . . . . . . . . . . . . . . . . . . . . .

OBJECTIVES . . . . . . . . . . . . . . . . . . . . . . . . . . . . . . . . . . . . . . . . . . . . . . . . .

METHODS . . . . . . . . . . . . . . . . . . . . . . . . . . . . . . . . . . . . . . . . .

RESULTS . . . . . . . . . . . . . . . . . . . . . . . . . . . . . . . . . . . . . . . . . . . .

Figure 1. . . . . . . . . . . . . . . . . . . . . . . . . . . . . . . . . . . . . . . . . . .

DISCUSSION . . . . . . . . . . . . . . . . . . . . . . . . . . . . . . . . . . . . . . 14

AUTHORS' CONCLUSIONS . . . . . . . . . . . . . . . . . . . . . . . . . . . . . . . . . . . 17

ACKNOWLEDGEMENTS . . . . . . . . . . . . . . . . . . . . . . . . . . . . . . . . . . . . . . 17

REFERENCES . . . . . . . . . . . . . . . . . . . . . . . . . . . . . . . . . . . . . . . . 17

CHARACTERISTICS OF STUDIES . . . . . . . . . . . . . . . . . . . . . . . . . . . . . . . . . . . . . . . . .

DATA AND ANALYSES . . . . . . . . . . . . . . . . . . . . . . . . . . . . . . . . . . . . . . . . . . . . . . . . . . . . .

Analysis 1.1. Comparison 1 Water quality intervention versus control: point and type of intervention (rate ratios), Outcome

1 Diarrhoea: all ages. . . . . . . . . . . . . . . . . . . . . . . . . . . . . . . . 5

Analysis 1.2. Comparison 1 Water quality intervention versus control: point and type of intervention (rate ratios), Outcome

2 Diarrhoea: children $<5$ years. . . . . . . . . . . . . . . . . . . . . . . . . . . . . . . . 53

Analysis 2.1. Comparison 2 Water quality intervention versus control: point of intervention (risk ratios), Outcome 1

Diarrhoea: all ages. . . . . . . . . . . . . . . . . . . . . . . . . . . . . . . . .

Analysis 2.2. Comparison 2 Water quality intervention versus control: point of intervention (risk ratios), Outcome 2 Diarrhoea: children $<5$ years.

Analysis 3.1. Comparison 3 Water quality intervention versus control: point and type of intervention (longitudinal prevalence ratios), Outcome 1 Diarrhoea: all ages. $\quad . \quad$. . . . . . . . . . . . . . . . . . . . . . . . . . .

Analysis 3.2. Comparison 3 Water quality intervention versus control: point and type of intervention (longitudinal prevalence ratios), Outcome 2 Diarrhoea: children $<5$ years. .

Analysis 4.1. Comparison 4 Water quality intervention versus control: point and type of intervention (odds ratios), Outcome 1 Diarrhoea: all ages. . . . . . . . . . . . . . . . . . . . . . . . . . . . .

Analysis 4.2. Comparison 4 Water quality intervention versus control: point and type of intervention (odds ratios),

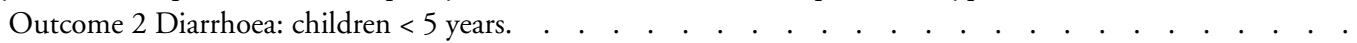

Analysis 5.1. Comparison 5 Water quality intervention versus control: point and type of intervention (means ratios), Outcome 1 Diarrhoea: all ages. 1

Analysis 5.2. Comparison 5 Water quality intervention versus control: point and type of intervention (means ratios), Outcome 2 Diarrhoea: children $<5$ years.

Analysis 6.1. Comparison 6 Water quantity intervention versus control: by compliance with intervention (risk ratios), Outcome 1 Diarrhoea: all ages. . . . . . . . . . . . . . . . . . . . . . . . . . . . .

Analysis 7.1. Comparison 7 Water quality intervention versus control: by compliance with intervention (odds ratios), Outcome 1 Diarrhoea: all ages. . . . . . . . . . . . . . . . . . . . . . . . . . . . . . .

Analysis 8.1. Comparison 8 Water quality intervention versus control: by ambient water quality (rate ratios), Outcome 1 Diarrhoea: all ages.

Analysis 9.1. Comparison 9 Water quality intervention versus control: by ambient water quality (risk ratios), Outcome 1 Diarrhoea: all ages.

Analysis 10.1. Comparison 10 Water quality intervention versus control: by ambient water quality (longitudinal prevalence ratios), Outcome 1 Diarrhoea: all ages.

Analysis 11.1. Comparison 11 Water quality intervention versus control: by ambient water quality (odds ratios), Outcome 1 Diarrhoea: all ages.

Analysis 12.1. Comparison 12 Water quality intervention versus control: by sufficiency of water quantity (long. prev. ratios), Outcome 1 Diarrhoea: all ages. . . . . . . . . . . . . . . . . . . . . . . . . . . . . . .

Analysis 13.1. Comparison 13 Water quality intervention versus control: by water supply level (rate ratios), Outcome 1 Diarrhoea: all ages.

Interventions to improve water quality for preventing diarrhoea (Review)

Copyright $\odot 2009$ The Cochrane Collaboration. Published by John Wiley \& Sons, Ltd. 
Analysis 14.1. Comparison 14 Water quality intervention versus control: by water supply level (risk ratios), Outcome 1 Diarrhoea: all ages. . . . . . . . . . . . . . . . . . . . . . . . . . . . . . . . .

Analysis 15.1. Comparison 15 Water quality intervention versus control: by water supply level (longitudinal prevalence ratios), Outcome 1 Diarrhoea: all ages.

Analysis 16.1. Comparison 16 Water quality intervention versus control: by water supply level (odds ratios), Outcome 1 Diarrhoea: all ages. . . . . . . . . . . . . . . . . . . . . . . . . . . . . . . . .

Analysis 17.1. Comparison 17 Water quality intervention versus control: by sanitation level (rate ratios), Outcome 1 Diarrhoea: all ages. . . . . . . . . . . . . . . . . . . . . . . . . . . . . . . . . . . .

Analysis 18.1. Comparison 18 Water quality intervention versus control: by sanitation level (risk ratios), Outcome 1 Diarrhoea: all ages. . . . . . . . . . . . . . . . . . . . . . . . . . . . . . . . .

Analysis 19.1. Comparison 19 Water quality intervention versus control: by sanitation level (longitudinal prevalence ratios), Outcome 1 Diarrhoea: all ages. . . . . . . . . . . . . . . . . . . . . . . . . . . . . . . . . . . . .

Analysis 20.1. Comparison 20 Water quality intervention versus control: simple and compound interventions (rate ratios), Outcome 1 Diarrhoea: all ages. . . . . . . . . . . . . . . . . . . . . . . . . . . . . . . . . . .

Analysis 21.1. Comparison 21 Water quality intervention versus control: simple and compound interventions (risk ratios), Outcome 1 Diarrhoea: all ages. . . . . . . . . . . . . . . . . . . . . . . . . . . . . . . . . .

Analysis 22.1. Comparison 22 Water quality intervention versus control: simple and compound interventions (longitudinal prevalence ratios), Outcome 1 Diarrhoea: all ages.

Analysis 23.1. Comparison 23 Water quality intervention versus control: simple and compound interventions (odds ratios), Outcome 1 Diarrhoea: all ages.

Analysis 24.1. Comparison 24 Water quality intervention versus control for RCTs: by methodological quality (rate ratios), Outcome 1 Diarrhoea: by allocation sequence. . . . . . . . . . . . . . . . . . . . . . . . . . .

Analysis 24.2. Comparison 24 Water quality intervention versus control for RCTs: by methodological quality (rate ratios), Outcome 2 Diarrhoea: by allocation concealment. . . . . . . . . . . . . . . . . . . . . . .

Analysis 24.3. Comparison 24 Water quality intervention versus control for RCTs: by methodological quality (rate ratios), Outcome 3 Diarrhoea: by follow up.

Analysis 24.4. Comparison 24 Water quality intervention versus control for RCTs: by methodological quality (rate ratios), Outcome 4 Diarrhoea: by blinding.

Analysis 25.1. Comparison 25 Water quality intervention versus control for RCTs: by methodological quality (risk ratios),

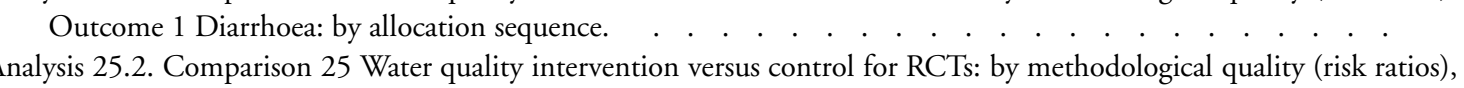
Outcome 2 Diarrhoea: by allocation concealment. . . . . . . . . . . . . . . . . . . . . . . .

Analysis 25.3. Comparison 25 Water quality intervention versus control for RCTs: by methodological quality (risk ratios), Outcome 3 Diarrhoea: by follow up. . . . . . . . . . . . . . . . . . . . . . . . . . . .

Analysis 25.4. Comparison 25 Water quality intervention versus control for RCTs: by methodological quality (risk ratios), Outcome 4 Diarrhoea: by blinding. . . . . . . . . . . . . . . . . . . . . . . . . . . . .

Analysis 26.1. Comparison 26 Water quality intervention versus control for RCTs: by methodological quality (longitudinal prevalence ratios), Outcome 1 Diarrhoea: allocation sequence. . . . . . . . . . . . . . . . . . . . . . .

Analysis 26.2. Comparison 26 Water quality intervention versus control for RCTs: by methodological quality (longitudinal prevalence ratios), Outcome 2 Diarrhoea: by allocation concealment. . . . . . . . . . . . . . . . . . . .

Analysis 26.3. Comparison 26 Water quality intervention versus control for RCTs: by methodological quality (longitudinal prevalence ratios), Outcome 3 Diarrhoea: by follow up. . . . . . . . . . . . . . . . . . . . . . . .

Analysis 26.4. Comparison 26 Water quality intervention versus control for RCTs: by methodological quality (longitudinal prevalence ratios), Outcome 4 Diarrhoea: by blinding. . . . . . . . . . . . . . . . . . . . .

Analysis 27.1. Comparison 27 Water quality intervention versus control for RCTs: by methodological quality (odds ratios), Outcome 1 Diarrhoea: by allocation sequence.

Analysis 27.2. Comparison 27 Water quality intervention versus control for RCTs: by methodological quality (odds ratios), Outcome 2 Diarrhoea: by allocation concealment. . . . . . . . . .

Analysis 27.3. Comparison 27 Water quality intervention versus control for RCTs: by methodological quality (odds ratios), Outcome 3 Diarrhoea: by follow up. . . . . . . . . . . . . . . . . . . . . . . . . . . . . . 100

Analysis 27.4. Comparison 27 Water quality intervention versus control for RCTs: by methodological quality (odds ratios),

Outcome 4 Diarrhoea: by blinding. . . . . . . . . . . . . . . . . . . . . . . . . . . . . 101 
Analysis 28.1. Comparison 28 Water quality intervention versus control for quasi-RCTs: by methodological quality (rate ratios), Outcome 1 Diarrhoea: by comparability of characteristics.

Analysis 28.2. Comparison 28 Water quality intervention versus control for quasi-RCTs: by methodological quality (rate ratios), Outcome 2 Diarrhoea: by contemporaneous of data collection. . . . . . . . . . . . . . . . . .

Analysis 29.1. Comparison 29 Water quality intervention versus control for quasi-RCTs: by methodological quality (risk ratios), Outcome 1 Diarrhoea: by comparability of characteristics. . . . . . . . . . . . . . . . . . . . .

Analysis 29.2. Comparison 29 Water quality intervention versus control for quasi-RCTs: by methodological quality (risk ratios), Outcome 2 Diarrhoea: by contemporaneous of data collection. . . . . . . . . . . . . . . 105

APPENDICES . . . . . . . . . . . . . . . . . . . . . . . . . . . . . . . . . . . . . 105

WHAT'S NEW . . . . . . . . . . . . . . . . . . . . . . . . . . . . . . . . . . . . . . . . 116

HISTORY . . . . . . . . . . . . . . . . . . . . . . . . . . . . . . . . . . . . . . . . 116

CONTRIBUTIONS OF AUTHORS . . . . . . . . . . . . . . . . . . . . . . . . . . . . . . . . . . . 116

DECLARATIONS OF INTEREST . . . . . . . . . . . . . . . . . . . . . . . . . . . . . . . . . . . 116

DIFFERENCES BETWEEN PROTOCOL AND REVIEW . . . . . . . . . . . . . . . . . . . . . . . . . 116

INDEX TERMS . . . . . . . . . . . . . . . . . . . . . . . . . . . . . . . . . . . . 117

Interventions to improve water quality for preventing diarrhoea (Review) 


\title{
[Intervention Review] \\ Interventions to improve water quality for preventing diarrhoea
}

\author{
Thomas F Clasen ${ }^{1}$, Ian G Roberts ${ }^{2}$, Taber Rabie ${ }^{3}$, Wolf-Peter Schmidt ${ }^{1}$, Sandy Cairncross ${ }^{3}$ \\ ${ }^{1}$ Department of Infectious and Tropical Diseases, London School of Hygiene \& Tropical Medicine, London, UK. ${ }^{2}$ Cochrane Injuries \\ Group, London School of Hygiene \& Tropical Medicine, London, UK. ${ }^{3}$ Department of Infectious and Tropical Diseases, Disease \\ Control and Vector Biology Unit, London School of Hygiene \& Tropical Medicine, London, UK \\ Contact address: Thomas F Clasen, Department of Infectious and Tropical Diseases, London School of Hygiene \& Tropical Medicine, \\ Keppel Street, London, WC1E 7HT, UK. thomas.clasen@1shtm.ac.uk.
}

Editorial group: Cochrane Infectious Diseases Group.

Publication status and date: Edited (no change to conclusions), published in Issue 1, 2009.

Review content assessed as up-to-date: 21 January 2006.

Citation: Clasen TF, Roberts IG, Rabie T, Schmidt WP, Cairncross S. Interventions to improve water quality for preventing diarrhoea. Cochrane Database of Systematic Reviews 2006, Issue 3. Art. No.: CD004794. DOI: 10.1002/14651858.CD004794.pub2.

Copyright (C) 2009 The Cochrane Collaboration. Published by John Wiley \& Sons, Ltd.

\begin{abstract}
A B S T R ACT
Background

Diarrhoeal diseases are a leading cause of mortality and morbidity, especially among young children in developing countries. While many of the infectious agents associated with diarrhoeal disease are potentially waterborne, the evidence for reducing diarrhoea in settings where it is endemic by improving the microbiological quality of drinking water has been equivocal.
\end{abstract}

\section{Objectives}

To assess the effectiveness of interventions to improve water quality for preventing diarrhoea.

\section{Search methods}

We searched the Cochrane Infectious Diseases Group Specialized Register (December 2005), CENTRAL (The Cochrane Library 2005, Issue 4), MEDLINE (December 2005), EMBASE (December 2005), and LILACS (December 2005). We also handsearched relevant conference proceedings, contacted researchers and organizations working in the field, and checked references from identified studies.

\section{Selection criteria}

Randomized and quasi-randomized controlled trials comparing interventions aimed at improving the microbiological quality of drinking water with no intervention in children and adults living in settings where diarrhoeal disease is endemic.

\section{Data collection and analysis}

Two authors independently assessed trial quality and extracted data. We used meta-analyses to estimate pooled measures of effect, where appropriate, and investigated potential sources of heterogeneity using subgroup analyses.

\section{Main results}

Thirty trials (including 38 independent comparisons) covering over 53,000 participants met the inclusion criteria. Differences between the trials limited the comparability of results and pooling by meta-analysis. In general, the evidence suggests that interventions to improve the microbiological quality of drinking water are effective in preventing diarrhoea both for populations of all ages and children less than five years old. Subgroup analyses suggest that household interventions are more effective in preventing diarrhoea than interventions 
at the water source. Effectiveness was positively associated with compliance. Effectiveness was not conditioned on the presence of improved water supplies or sanitation in the study setting, and was not enhanced by combining the intervention to improve water quality with other common environmental interventions intended to prevent diarrhoea.

\section{Authors' conclusions}

Interventions to improve water quality are generally effective in preventing diarrhoea, and interventions to improve water quality at the household level are more effective than those at the source. Significant heterogeneity among the trials suggests that the actual level of effectiveness may depend on a variety of conditions that research to date cannot fully explain. Rigorous, blinded, multi-arm randomized controlled trials conducted over a longer duration in a variety if settings may help clarify the potential effectiveness.

\section{PLAIN LANGUAGE SUMMARY}

Interventions to improve water quality, particularly when implemented at the household level, are effective in preventing diarrhoea in settings where it is endemic

Diarrhoea is a major cause of death and disease, especially among young children in low-income countries. Loss of fluid (dehydration) is the major threat, though diarrhoea also reduces the absorption of the nutrients, causing poor growth in children, reduced resistance to infection, and potentially long-term gut disorders. This review examined trials of interventions to improve the microbiological quality of drinking water. These include conventional improvements at the water source (eg protected wells, bore holes, and stand posts) and point-of-use interventions at the household level (eg chlorination, filtration, solar disinfection, and combined flocculation and disinfection). The review covered 38 independent comparisons from 30 trials that involved more than 53,000 people. In general, such interventions were effective in reducing episodes of diarrhoea. Household interventions were more effective in preventing diarrhoea than those at the source. However, differences in the interventions and the settings in which they were introduced, as well as the methods and measurements of effect, limit the extent to which generalizations can be made. Further research, including blinded trials and longer-term assessments, is necessary to understand the full impact of these interventions.

\section{B A C K G R O U N D}

\section{Diarrhoeal disease, disease agents, and pathways}

Diarrhoeal diseases kill an estimated 1.8 million people each year (WHO 2005). Among infectious diseases, diarrhoea ranks as the third leading cause of both mortality and morbidity (after respiratory infections and HIV/AIDS), placing it above tuberculosis and malaria. Young children are especially vulnerable, bearing $68 \%$ of the total burden of diarrhoeal disease (Bartram 2003). Among children less than five years, diarrhoea accounts for $17 \%$ of all deaths (United Nations 2005). For those infected with the human immunodeficiency virus (HIV) or who have developed acquired immunodeficiency syndrome (AIDS), diarrhoea can be prolonged, severe, and life-threatening (Hayes 2003).

Diarrhoea is a symptom complex characterized by stools of decreased consistency and increased number. The clinical symptoms and course of the disease vary greatly with the age, nutritional status, and immunocompetence of the patient, and the aetiological agent infecting the intestinal system and interfering with normal adsorption. Most cases resolve within a week, though a small percentage continue for two weeks or more and are characterized as 'persistent' diarrhoea. Dysentery is a diarrhoeal disease defined by the presence of blood in the liquid stools (Blaser 1995). About $35 \%$ of the deaths from diarrhoea in children less than five years old are believed to be attributable to acute non-dysenteric diarrhoea, with $45 \%$ from persistent diarrhoea and $20 \%$ from dysentery (Black 1993). Though epidemic diarrhoea such as cholera and shigellosis (bacillary dysentery) are well-known risks, particularly in emergency settings, their global health significance is small compared to endemic diarrhoea (Hunter 1997).

The immediate threat from diarrhoea is dehydration - a loss of fluids and electrolytes. Thus, the widespread promotion of oral rehydration therapy (ORT) has significantly reduced the case-fatality rate associated with the disease. Such improvements in case management, however, have not reduced morbidity, which is estimated at four billion cases annually (Kosek 2003). And since diarrhoeal diseases inhibit normal ingestion of foods and adsorp- 
tion of nutrients, continued high morbidity is an important cause of malnutrition, leading to impaired physical growth and cognitive function (Guerrant 1999), reduced resistance to infection (Baqui 1993), and potentially long-term gastrointestinal disorders (Schneider 1978).

The infectious agents associated with diarrhoeal disease are transmitted chiefly through the faecal-oral route (Byers 2001). A wide variety of bacterial, viral, and protozoan pathogens excreted in the faeces of humans and animals are known to cause diarrhoea. Among the most important of these are Escherichia coli, Salmonella sp., Shigella sp., Campylobacter jejuni, Vibrio cholerae, rotavirus, norovirus, Giardia lamblia, Cryptosporidium sp., and Entamoeba histolytica (Leclerc 2002). The importance of individual pathogens varies between settings, seasons, and conditions. While bacterial agents as a group are believed to cause a majority of diarrhoeal disease in developing countries, viral and protozoan agents tend to cause more cases in developed countries (Hunter 1997).

Many of these diarrhoegenic agents are potentially waterborne transmitted through the ingestion of contaminated water. However, most of the same pathogens are also transmitted by ingestion of contaminated food and other beverages, by person-to-person contact, and by direct or indirect contact with infected faeces. Because of this variety of pathways, interventions for the prevention of diarrhoeal disease not only include enhanced water quality but also steps to improve the proper disposal of human faeces (sanitation), increase the quantity and improve access to water (water supply), and promote hand washing and other hygiene practices within domestic and community settings (hygiene).

While water quality is also adversely impacted by chemical contaminants, the level of disease associated with metals, nitrates, organics, and other chemicals is usually small relative to infectious diarrhoea (WHO 2002). Other important diseases associated with drinking water, such as hepatitis A and E, poliomyelitis, gastroenteritis and typhoid fever, may not cause diarrhoea but are nevertheless associated with potentially waterborne microbes of faecal origin. For this reason, efforts to assess drinking water quality focus primarily on faecal pathogens (WHO 1993).

Because of the difficulty of monitoring water for the presence of all such agents, an indirect approach has been adopted where water is examined for indicator bacteria whose presence implies some degree of contamination. While there is controversy over the preferred indicator (Gleeson 1997), even those that accept the use of the coliform group use different target indicators (total coliforms, thermotolerant coliforms, E. coli) and different methods for assaying the level of indicator present (membrane filtration, multiple tube/most probable number) (Clesceri 1998).

\section{Water quality and diarrhoea}

Health authorities generally accept that microbiologically safe water plays an important role in preventing outbreaks of waterborne diseases (Hunter 1997). Accordingly, the most widely accepted guidelines for water quality allow no detectable level of harmful pathogens at the point of distribution (WHO 2004).

However, an estimated 1.1 billion people lack access to improved water supplies (WHO/UNICEF 2000). In settings that are not served by reliable water treatment and distribution systems, diarrhoeal disease is often endemic, that is, present or usually prevalent in the population at all times. In such settings much of the epidemiological evidence for increased health benefits following improvements in the quality of drinking water has been equivocal (Esrey 1986; Lindskog 1987; Cairncross 1989). Because of the multiple pathways of diarrheogenic infection, improvements in water quality alone may not necessarily interrupt transmission (Briscoe 1984). There are also questions about the methods and validity of studies designed to assess the health impact of such interventions (Blum 1983; Briscoe 1986; Imo State Team 1989).

As part of a larger evaluation of interventions for the control of diarrhoeal disease (Feachem 1983), in 1985, Esrey and colleagues reviewed studies to determine the health impact from improvements in water supplies and excreta disposal facilities (Esrey 1985). They updated the review in 1991 and expanded it to include studies addressing a variety of specific pathogens associated with poor water and sanitation (Esrey 1991a). For almost two decades, these reviews have provided guidance on the relative reduction in diarrhoeal disease that was believed to be possible through improvements in water quality, water quantity, sanitation, and hygiene. Important as these reviews have been, there are reasons to consider anew the extent to which interventions to improve water quality impact diarrhoeal disease. This is largely the result of new evidence from interventions at the household level (Clasen 2004a). However, even the league tables in Esrey's reviews comparing the relative impact of various types of environmental interventions, enticingly simple as they are, may obscure the potentially more important finding - the wide range among the studies in the measure of effect. In the case of water quality improvements, for example, Esrey and colleagues cited a median reduction in diarrhoea disease from nine studies of $16 \%$, but a range in effect from $0 \%$ to $90 \%$. Because Esrey and colleagues had a relatively small number of studies on water quality interventions, they could not use subgroup analysis to explore some of the potential reasons for this wide range of effect (Mintz 2001; Clasen 2004a).

An update of Esrey's reviews addresses some of these shortcomings (Fewtrell 2005). By using subgroup analysis, for example, Fewtrell and colleagues found important differences in effectiveness of the intervention based on the point of treatment (source versus household). They also observed that interventions were effective even in the absence of improved sanitation (a new finding that challenged the view expressed by Esrey 1986 and VanDerslice 1995), as well as the apparent absence of a cumulative effect from multiple environmental interventions. At the same time, with respect to interventions to improve water quality, the review omitted a number of studies that would seem to have met the inclusion criteria. Moreover, the review presented certain methodological issues, 
such as the inclusion of observational studies (Ghannoum 1981; Sathe 1996; Iijima 2001), studies where the outcome was other than endemic diarrhoea (Ghannoum 1981; lijima 2001; Colwell 2003), and the homologous treatment of studies with different measures of effect in their meta-analysis.

\section{Water treatment}

A number of interventions have been developed to improve the microbiological quality of water and can be grouped into four main categories.

- Physical removal of pathogens (eg filtration, adsorption, or sedimentation).

- Chemically treating water to kill or deactivate pathogens, most commonly with chlorine.

- Disinfection by heat (eg boiling or pasteurization) and ultraviolet (UV) radiation, either using the sun (solar disinfection) or an artificial UV lamp.

- Combination of these approaches (eg filtration or flocculation combined with disinfection).

Water quality can also be enhanced by protecting it from recontamination, for example, by residual disinfection, piped distribution, and safe storage. A combination approach is also common in conventional systems since individual approaches are not effective against the full range of microbial pathogens under all water conditions. Mechanical removal of viruses, for example, presents a challenge to most filters due to their submicron size. Similarly, certain encysted protozoa are resistant to chemical disinfection. The microbiological performance of these approaches may also be impacted by the temperature, $\mathrm{pH}$, turbidity, chemical content, and other characteristics of the water.

In higher income countries, and in many urban settings worldwide, drinking water is treated centrally at the source of supply and is distributed to consumers through a network of pipes and household taps. However, such conventional systems involve significant upfront investment and continued maintenance. In remote and low-income settings, water quality may nevertheless be improved at the source by, for example, providing protected groundwater (springs, wells, and bore holes) or harvested rainwater as an alternative to surface sources (rivers and lakes) that are more susceptible to faecal contamination. Microbial water quality may also be improved at the source or other point in the distribution system by chlorination, filtration, and other means. Improving water at the source is also frequently accompanied by improvements in quantity or access to water by increasing the volume or frequency of water delivery or reducing the time spent in collecting water. This may result in significant benefits not only in health but also in economic and social welfare (Hutton 2004). For purposes of this review, any form of treatment at the water source or otherwise prior to the point of use will be referred to collectively as 'source' water treatment.
For those who have access to sufficient quantities of water but whose water is of poor microbiological quality, an alternative is to treat water at the household or other point of use. Such household treatment may minimize recontamination in the home, a wellknown cause of water quality degradation (Wright 2004). At the same time, certain household water filters have been associated with adverse health impacts (Payment 1991a). A review commissioned by the World Health Organization (WHO) identified a wide variety of options for household-based water treatment and assessed the available evidence on their microbiological effectiveness, health impact, acceptability, affordability, sustainability, and scalability (Sobsey 2002). Research on the economics of such interventions also suggests that where adequate quantities of water are already available, household-based water treatment is among the most cost-beneficial and cost-effective approaches in preventing diarrhoeal disease (WHO 2002; Hutton 2004). There is also evidence that the vulnerable population to whom such householdbased interventions have been targeted will pay all or a portion of the cost of household water treatment products (Clasen 2004c).

\section{O B J E C T I VES}

To assess the effectiveness of interventions to improve water quality for preventing diarrhoea.

\section{METHODS}

\section{Criteria for considering studies for this review}

\section{Types of studies}

Randomized and quasi-randomized controlled trials. The unit of randomization may include individuals, families, households, communities, or other clusters.

\section{Types of participants}

Children and adults from settings where diarrhoeal disease is endemic.

\section{Types of interventions}

\section{Intervention}


Interventions aimed at improving the microbiological quality of drinking water, including steps to improve water quality by removing or inactivating microbiological pathogens (eg filtration, sedimentation, chemical treatment, heat, or UV radiation) and protecting the microbiological integrity of water prior to consumption (eg residual disinfection, protected distribution, or improved storage). An intervention that has shown elsewhere to reduce the quantity or pathogenicity of waterborne microbes is deemed, for purposes of the review, as an intervention to improve water quality, even if the particular study did not record such an improvement by microbiological examination.

We include interventions that combine improvements in water quality with other components such as improvements in water quantity or access, sanitation or hygiene. We have excluded studies of interventions designed to reduce diarrhoea through improvements in sanitation, hygiene, water quantity or water access, but which do not include a water quality improvement.

\section{Control}

People who are following their usual practices with respect to drinking water rather than the prescribed intervention, or who have received a different type of intervention. For example, where a protected well or borehole is introduced, controls may be consuming water that is obtained from the previously available sources, often untreated surface waters. In trials involving household water treatment, controls normally procure their water from the same source as the intervention group but have not received the intervention to treat water in the home. Appendix 3 provides details on the control groups for each study.

\section{Types of outcome measures}

\section{Primary}

- Diarrhoea episodes among individuals, whether or not confirmed by microbiological examination.

The WHO definition of diarrhoea is three or more loose or fluid stools (that take the shape of the container) in a 24-hour period (WHO 1993). We defined diarrhoea and an episode in accordance with the case definitions used in each trial.

\section{Secondary}

- Death

- Adverse events.

Note: We excluded trials that had no clinical outcomes; for example, trials that only report on microbiological pathogens in the stool.

\section{Search methods for identification of studies}

We attempted to identify all relevant trials regardless of language or publication status (published, unpublished, in press, and in progress).

\section{Databases}

We searched the following databases using the search terms and strategy described in Appendix 1: Cochrane Infectious Diseases Group Specialized Register (December 2005); Cochrane Central Register of Controlled Trials (CENTRAL), published in The Cochrane Library (2005, Issue 4); MEDLINE (1966 to December 2005); EMBASE (1974 to December 2005); and LILACS (1982 to December 2005).

\section{Conference proceedings}

We searched the following conference proceedings of the following organizations for relevant abstracts: International Water Association (IWA) (1990 to December 2005); and Water, Engineering and Development Centre, Loughborough University, UK (WEDC) (1973 to December 2005).

\section{Researchers and organizations}

We contacted individual researchers working in the field and the following organizations for unpublished and ongoing trials: Water, Sanitation and Health Programme of the World Health Organization; World Bank Water and Sanitation Program; UNICEF Water, Environment and Sanitation (WES); and IRC International Water and Sanitation Centre; Foodborne and Diarrhoeal Diseases Branch, Division of Bacterial and Mycotic Diseases, Centers for Disease Control and Prevention (CDC); US Agency for International Development (USAID), including its Environmental Health Project (EHP); and the UK Department for International Development (DFID).

\section{Reference lists}

We checked the reference lists of all studies identified by the above methods.

\section{Data collection and analysis}

\section{Selection of studies}

Thomas Clasen (TC) and Tamer Rabie (TR) independently reviewed the titles and abstracts located in the searches and selected all potentially relevant studies. After obtaining the full articles, we 
independently determined whether they met the inclusion criteria. Where we were unable to agree, we consulted Sandy Cairncross (SC) and arrived at a consensus. Those potentially relevant studies that were ultimately excluded are listed together with the reason for exclusion in the 'Characteristics of excluded studies'. the control group. Because this review is largely descriptive, we elected to include all trial arms but to note this problem. We note, however, that this has occurred and the meta-analysis result will be artificially precise.

\section{Data extraction and management}

TC and TR used a pre-piloted form to extract and record the data described in Appendix 2, and TC attempted to contact authors to supply missing data. TC entered the extracted data into Review Manager 4.2.

TC and TR or Wolf-Peter Schmidt (WS) independently extracted, and where necessary calculated, the measure of effect of the intervention on diarrhoea. We extracted and reported the measure of effect as reported by the authors of each trial, whether it be risk ratios, rate ratios, odds ratios, longitudinal prevalence ratios, or means ratios. In this context, longitudinal prevalence is the number of days with diarrhoea divided by the number of days under observation (Morris 1996). In using these various measures of effect, we note the design effect in treating all such measures of effect as equivalent for common outcomes such as diarrhoea and the debate about methodologies for converting such measures of effect into a single measure (Zhang 1998; McNutt 2003). While it would be possible to calculate a single measure of effect for most trials based on the raw study data, we elected not to do so for the following reasons. Although all trials included in the review assess outcomes on an individual level, the unit of randomization is not the individual but a household, group of households, neighbourhood, or village. As described below, most included trials correct for this design effect by adjusting for the inter-cluster variance. Studies of diarrhoeal disease also frequently adjust for other common covariates, including age and repeated episodes within the same participant. Because these adjustments are generally deemed appropriate, a re-calculation of a measure of effect based on raw data would ignore these important adjustments. In order to avoid the homologous treatment of these different measures of effect, we include the pooled measures of effect in the comparisons only across trials reporting the same measure of effect. In the subgroup analyses, when there were too few trials with the same measure of effect, the comparisons show the forest plots only, with no calculation of pooled measures of effect.

As discussed more fully below, a number of the included trials had multiple intervention arms (eg treating water with bleach or with a flocculant and disinfectant) and compared two or more intervention groups against a single control group. In such cases, a metaanalysis that treats each intervention arm as a separate trial results in counting the control group once for each arm. This violates the important principle in the methodology of meta-analysis that each individual be included only once. However, for the reasons noted in the preceding paragraph, it was not possible to return to the raw data from the trials and thus correct for this by dividing

\section{Assessment of risk of bias in included studies}

TC and TR independently assessed the risk of bias in the trials. We classified the generation of allocation sequence - the process used to generate the randomization list - as 'adequate' if the method used is described and the resulting sequences are unpredictable (eg computer-generated random numbers, table of random numbers, coin toss, drawing lots); 'unclear' if stated that the trial is randomized, but the method is not described; or 'inadequate' if sequences could be related to outcomes (eg according to case record number, date of birth, alternation). We classified allocation concealment - the process used to prevent foreknowledge of group assignment - as 'adequate' if the participants or the investigators enrolling participants cannot foresee assignment; 'unclear' if method is not described; or 'inadequate' if participants and investigators enrolling the participants can foresee their upcoming assignment. We classified blinding - whether the participant or outcome assessor is blind to the intervention group - as 'double blind' if the trial uses a placebo or double-dummy technique such that neither the participants nor the assessor knows whether or not the participants receive the intervention; 'single blind' if the participant or the assessor knows whether or not the participant receives the intervention; or 'open' if both participant and assessor know whether or not the participant receives the intervention. We classified the inclusion of randomized participants in the analysis as 'adequate' if $90 \%$ or more of all participants randomized to the trial were included in the analysis; 'unclear' if it is not clear what portion of participants randomized to the trial were included in the analysis; or 'inadequate' if less than $90 \%$ of all participants randomized to the trial were included in the analysis.

Additionally, we assessed quasi-randomized controlled trials using the following criteria:

1. Comparability of characteristics between intervention and control groups with respect to relevant baseline characteristics such as water quality, diarrhoeal morbidity, age, socioeconomic status, access to water, hygiene practices, and sanitation facilities. We classified this as 'adequate' if no substantial differences were present, 'unclear' if not reported or not known whether substantial differences exist, or 'inadequate' if one or more substantial difference exists.

2. Data collection for intervention and control groups at the same time. We classified this as 'adequate' if data were collected at similar points in time, 'unclear' if the relative timing was not reported or not clear from trial, or 'inadequate' if data were not collected at similar points in time. 


\section{Data synthesis}

We entered the estimates of effect using the generic inverse variance method on the log scale (Higgins 2005a), and analysed the data using Review Manager 4.2.

We performed tests for heterogeneity by visually examining the forest plots and by using the chi-squared test for heterogeneity with a $10 \%$ level of statistical significance (Egger 2001) and the $I^{2}$ test for consistency (Higgins 2003). In accordance with our protocol, where there was evidence of heterogeneity we performed the following subgroup analyses: age (all ages versus children less than five years old); intervention point (source versus household); intervention type; water quality only versus compound interventions (ie with hygiene message, vessel, improved sanitation, improved supply); ambient water quality (ie water testing results at pre-intervention or of control group based on log scale levels of thermotolerant coliform per $100 \mathrm{~mL}$ ); compliance with intervention $(<50 \%$ versus $\geq 50 \%)$, and effectiveness under various water supply, sanitation, and water access conditions. In the subgroup analyses based on water supply, we followed terminology used by the WHO/UNICEF Global Assessment (WHO/UNICEF 2000), using 'unimproved' to extend to unprotected wells or springs, vendor- or tanker-provided water or bottled water, and 'improved' to extend to household connections, public standpipes, boreholes, protected dug wells or springs, or rainwater collection; we categorized trials as 'unclear' with respect to water supply if they contained insufficient information. We used the same definitions from the WHO/UNICEF Global Assessment to classify sanitation conditions as 'improved' (connection to a public sewer or septic system, pour-flush latrine, simple pit latrine, ventilated improved pit latrine) or 'unimproved' (service or bucket latrines, public latrines, open latrines ); where the necessary information was unclear or unreported, we categorized the sanitation facilities as 'unclear'. To subgroup trials based on access to water source, we used the classifications defined by The Sphere Project 2004, classifying access as 'sufficient' if a consistently available source was located within 500 metres, with queuing no more than 15 minutes and filling time for a 20 litres container no more than three minutes, 'insufficient' if any access failed any such criteria, and 'unclear' if such criteria was unreported or unclear. The quantity of water available to study participants was considered 'sufficient' if consisting of a minimum of 15 litres per person per day. We also used subgroup analyses to compare effectiveness based on methodological quality of the trials.

Where appropriate, we used meta-analyses to derive pooled estimates of effect. Because of the substantial heterogeneity in study results, we used the random-effects model (rather than the fixedeffect model) in such pooling. However, because of important differences in trial methodology, settings, and intervention types, we caution that such pooling of results may be misleading.

Finally, we produced a funnel plot to explore publication bias. We chose not to present results from statistical analysis of publication bias since they are not yet fully accepted as clear evidence of pub- lication bias (Egger 2001).

\section{R E S U L T S}

\section{Description of studies}

See: Characteristics of included studies; Characteristics of excluded studies; Characteristics of studies awaiting classification.

\section{Search results}

Execution of the search strategy elicited 976 titles and abstracts, 939 from the databases and 37 from the other sources. These titles and abstracts were screened, and the full text articles of 68 studies were obtained for further assessment. Of these 68 studies, 30 met the review's inclusion criteria (see 'Characteristics of included studies'), 34 were excluded for the reasons given in the 'Characteristics of excluded studies', and four studies were identified after this review was prepared and are awaiting assesssment (see 'Characteristics of studies awaiting classification'). One of the trials that met the inclusion criteria had inadequate information on disease morbidity to include in the analysis (Torun 1982); we were unable to contact the trial authors and therefore only provide a description of this trial. Four of the included trials had two relevant intervention arms, one had three arms and one had four arms (described as i to iv), making a total of 38 discrete comparisons (excluding Torun 1982) from the 30 included trials.

Of the 30 included trials, 18 were published in journals, one in a book, two were included in $\mathrm{PhD}$ dissertations, and nine were unpublished as of 31 December 2004. All but three trials were reported in English; we worked from the original French and Spanish text for Messou 1997 and URL 1995-i, and from a translation for Xiao 1997. Most of the trials were conducted recently: 10 were completed or published in 2004 alone, and 16 since 2000; only three are from the 1980s and none before 1982.

\section{Study design and length}

Nineteen trials were randomized and 11 were quasi-randomized. Study design varied with the type of intervention: 19 of 23 trials of household interventions were randomized controlled trials; and the all seven trials of interventions at the water source or other point prior to distribution used quasi-randomization. Most randomized controlled trials used households as the unit of randomization, while some used neighbourhoods or other clusters of households (Chiller 2004; Doocy 2004; Luby 2004b-i), or villages or other communities (Austin 1993-i).

The intervention period ranged from 9.5 weeks to 3 years. The duration of the randomized controlled trials (median 5 months, range 9.5 weeks to 12 months) tended to be shorter than in the 
quasi-randomized controlled trials (median 12 months, range 3 to 60 months). Trials of interventions at the point of distribution (used mainly in the quasi-randomized controlled trials) were also longer (median 36 months, range 12 months to 60 months) than those of point-of-use interventions (median 5 months, range 9.5 weeks to 12 months).

Most of the trials were undertaken to investigate the effectiveness of the intervention and not as an assessment of an ongoing programme.

\section{Participants and settings}

The 30 trials included at least 53,476 participants (the number of participants in Garrett 2004 was not reported). The 19 randomized controlled trials included at least 29,920 participants (median 607 , range 112 to 6650), and the 11 quasi-randomized controlled trials included 23,556 participants (median 972, range 150 to 9600 ). The seven trials of point-of-distribution interventions included 18,336 participants (median 804, range 150 to 9600), while the 23 trials of point-of-use interventions included at least 35,140 participants (median 875, range 112 to 6650).

Fifteen trials enrolled and presented results for all ages of participants, and nine trials included only children under five years or a subgroup thereof (Alam 1989; Austin 1993-i; Mahfouz 1995; URL 1995-i; Handzel 1998; Gasana 2002; Jensen 2003; du Preez 2004; Garrett 2004). The other trials used alternative age criteria for participants, but we extracted data on children less than five years old where available.

Except for one trial that took place in the USA (Colford 2002), all trials were undertaken in developing countries: Bangladesh (Alam 1989; Aziz 1990; Handzel 1998), Bolivia (Quick 1999; Clasen 2004b; Clasen 2004c), Brazil (Kirchhoff 1985), China (Xiao 1997), Guatemala (Torun 1982; URL 1995-i; Reller 2003-i; Chiller 2004), Gambia (Austin 1993-i), Ivory Coast (Messou 1997), Liberia (Doocy 2004), Kenya (Conroy 1996; Conroy 1999; Crump 2004-i; Garrett 2004), Malawi (Roberts 2001), Pakistan (Jensen 2003; Luby 2004a-i; Luby 2004b-i), Rwanda (Gasana 2002), Saudi Arabia (Mahfouz 1995), South Africa/Zimbabwe (du Preez 2004), Uganda (Lule 2005), Uzbekistan (Semenza 1998), and Zambia (Quick 2002). Two trials took place in urban settings (Semenza 1998; Colford 2002), two in peri-urban settings (Quick 1999; Quick 2002), three in urban informal or squatter settlements (Handzel 1998; Luby 2004a-i; Luby 2004b-i), two in camps for refugees or displaced persons (Roberts 2001; Doocy 2004), one in multiple settings (URL 1995-i), and the others in villages or other rural settings.

\section{Primary drinking water supply and sanitation facilities (Appendix 3)}

The primary drinking water supply before the intervention, and which was continued as the control in the trials, was 'unimproved' in 18 trials, 'improved' in 8 trials, and 'unclear' or not reported in three trials. Sanitation facilities in trial settings were 'improved' in eight trials, 'unimproved' in nine trials, and 'unclear' or unreported in 13 trials. Access to a water source was deemed 'sufficient' in eight trials and 'unclear' or unreported in the remainder; no trials reported a setting that provided insufficient access to a water source. The quantity of water available to study participants was considered 'sufficient' in seven trials, 'insufficient' in three trials, and 'unclear' in 20 trials.

Twenty-three of the trials measured the microbial contamination of the drinking water before the introduction of the intervention as an indication of the ambient risk and the microbiological quality of the water consumed by the control group. Eighteen measured colony-forming units (CFU) of thermotolerant coliforms, faecal coliforms, or E. coli. Other trials measured the frequency of samples containing such bacteria, or the CFU of total coliforms or other indicators of microbial contamination. None continually measured the microbiological performance of their interventions against the full range of bacterial, viral, and protozoan pathogens known to cause diarrhoea.

\section{Interventions (Appendix 4)}

Each trial investigated an intervention to improve the microbial quality of drinking water, either at the source or at the household level. The source-based interventions were improved wells or bore holes (Alam 1989; Aziz 1990; Xiao 1997), improved sources and distribution to public tap stands (Torun 1982; Gasana 2002; Jensen 2003), and one an unspecified improvement leading to a public tap stand (Messou 1997); none involved piped-in (reticulated) household connections. We grouped the point-of-use interventions around improved storage (Roberts 2001) or one of four basic technologies for treating water in the home: chlorination (Kirchhoff 1985; Austin 1993-i; Mahfouz 1995; Handzel 1998; Semenza 1998; Quick 1999; Quick 2002; Reller 2003-i; Crump 2004-i; Garrett 2004; Luby 2004a-i; Luby 2004b-i; Lule 2005); solar disinfection (Conroy 1996; Conroy 1999); filtration (URL 1995-i; Colford 2002; Clasen 2004b; Clasen 2004c; du Preez 2004); and combination flocculation-disinfection using the Procter \& Gamble PUR(r) product (Reller 2003-i; Chiller 2004; Crump 2004-ii; Luby 2004b-i). It must be noted, however, that apart from singular interventions such as solar disinfection and PUR, these groups are not homologous; for example, filtration interventions varied by filter medium and pore size, and chlorination varied by chlorine source, dose, and contact time.

Many trials also used other interventions, such as some type of supplemental hygiene education or instruction beyond the use of the intervention itself (Alam 1989; Chiller 2004; Crump 2004-i; Luby 2004b-ii), in some cases combined with an improvement in sanitation facilities (Aziz 1990; Messou 1997; Xiao 1997) and oral rehydration therapy (Messou 1997). Among point-of-use interventions, household-based water treatment was often combined 
with some form of improved storage (Doocy 2004; Luby 2004a-i; Luby 2004b-i; Lule 2005), hygiene support for the intervention (URL 1995-ii; Chiller 2004), or both (Handzel 1998; Semenza 1998; Quick 1999; Quick 2002); and in one case together with improved supply and sanitation (Garrett 2004). In only one multiple-intervention arm trial did investigators establish different intervention groups with and without hygiene or other non-water improvement steps in order to isolate the impact of water quality (URL 1995-i; URL 1995-ii). The remaining 14 trials did not use other material interventions, although the ceramic filters (Clasen 2004b; Clasen 2004c; du Preez 2004) and solar disinfection (Conroy 1996; Conroy 1999) used in some may have also improved storage.

Seven trials did not report actually having measured microbial water quality (Alam 1989; Aziz 1990; Conroy 1999; Garrett 2004; Luby 2004b-i; Messou 1997; Xiao 1997). Thus, it cannot be concluded definitively that the interventions investigated in these trials actually resulted in an improvement in drinking water quality. Nevertheless, in accordance with the decision expressed in the protocol for this review - that interventions such as protection of wells or springs that have generally been shown to improve water quality will be included even without measuring the same - they are included in this review. Among the seven trials investigating interventions to improve water quality at the point of distribution, only three tested microbial water quality (Torun 1982; Gasana 2002; Jensen 2003). Because these tests were at the source or point of distribution and not the point of use, their results do not reflect possible post-collection contamination.

Compliance with the intervention (ie consumption of the improved quality water) is an important factor in assessing potential impact of the intervention. Nevertheless, none of the trials assessed this directly. Trials of source water interventions tended to assume compliance based on the fact that the primary water supply had been improved. Some trials of household water treatment undertook indirect assessments of compliance by measuring residual chlorine levels in stored household water (Austin 1993-i; Mahfouz 1995; Handzel 1998; Semenza 1998; Quick 1999; Quick 2002; Reller 2003-i; Chiller 2004; Crump 2004-i; Doocy 2004; Garrett 2004), comparing microbial water quality of intervention and control households (Kirchhoff 1985; Chiller 2004; Clasen 2004b; Clasen 2004c; Crump 2004-i), conducting periodic or post-study surveys (Reller 2003-i; Chiller 2004; Doocy 2004), or counting the amount of intervention product used (Reller 2003-i). Most other trials measured compliance only by occasional observation, while seven did not report on compliance (Torun 1982; Alam 1989; Xiao 1997; Conroy 1999; Gasana 2002; Luby 2004a-i; Lule 2005). The trials of chorine residuals reported compliance ranging from a high of $95 \%$ (Doocy 2004) to a low of 27\% (Reller 2003-i). Even among these trials, however, investigators acknowledged that it was not possible to know to what extent intervention group participants actually consumed treated water or avoided consuming untreated water. None of the trials reported on differences in out- come based on level of compliance within that trial's population itself.

Most interventions at the point of distribution also involved improvements in supply that probably also increased water quantity or access, or both, though none of these trials reported any measurements. Such improvements may be a separate and possibly more significant contributor to health than water quality.

Generally the controls continued to use their pre-trial water supply and treatment practices. In the two trials of solar disinfection (Conroy 1996; Conroy 1999), however, both intervention and control households received plastic bottles for storing their drinking water. The intervention group was instructed to place the bottles on roofs to expose them to the sun, while the control group was told to keep the filled bottles indoors. The investigator did not explain whether this was designed to assist in blinding, to comply with ethics conditions, or had some other objective. It is important to note that since improved storage even in the absence of treatment has been shown to improve microbial water quality (Wright 2004) and prevent diarrhoea (Roberts 2001), the comparison between the intervention and control in these trials may understate the effectiveness of the intervention when compared to the controls following customary water handling practices.

\section{Outcome measures}

The trials' main outcome measure was diarrhoeal disease, but different methods were used to define, assess, and report it. Eighteen trials used the WHO's definition of diarrhoea, while the other trials used the mother's or other respondent's definition (Austin 1993-i; Messou 1997; Gasana 2002; Reller 2003-i; Chiller 2004; Crump 2004-i), watery diarrhoea as a component of gastroenteritis (Colford 2002), the local term (Conroy 1996; Conroy 1999), or a "significant change in bowel habits towards decreased consistency or increased frequency" (Kirchhoff 1985). Two trials did not report the case definition used for diarrhoea (Torun 1982; Xiao 1997).

The method of diarrhoea surveillance and assessment also varied. In most cases, participants were visited on a periodic basis, either weekly (13 trials), biweekly (five trials), or more infrequently (four trials), and were asked to recall and report on cases of diarrhoea during a previous period, usually seven days (16 trials) or 14 days (six trials). The other trials asked each participant or a designated householder to keep a log or record to indicate days with or without diarrhoea (Austin 1993-i; Colford 2002; du Preez 2004), procured data on diarrhoea from family records and disease registries (Mahfouz 1995), or used paediatricians to assess the participants during regular medical checkups (Gasana 2002). Only one trial did not report the method (Xiao 1997).

Using these data, investigators reported diarrhoeal disease using one or more of the following epidemiological measures of disease frequency: incidence (19 trials); period prevalence (six trials); and longitudinal prevalence (six trials). The trials also reported other 
measures of disease, including incidence of persistent diarrhoea (Chiller 2004), gastrointestinal illness, including specific symptoms thereof (Colford 2002), incidence or prevalence of bloody diarrhoea (Doocy 2004; du Preez 2004), and days of work or school lost due to diarrhoea (Lule 2005). Two trials also reported on death associated with diarrhoea (Messou 1997; Crump 2004-i). None reported on other adverse outcomes.

\section{Data presentation}

The different means of assessing and reporting diarrhoea led to a variety of effect measures, including risk ratios (10 trials), rate ratios (5 trials), longitudinal prevalence ratios (seven trials), odds ratios (six trials), and a ratio of means (Quick 1999). As noted above, Torun 1982 did not include sufficient information on diarrhoea to estimate the measure of effect.

Results were presented for the different age groups: 10 trials presented results both for children under five years (or a subgroup thereof) and for all ages or older age groups (Kirchhoff 1985; Semenza 1998; Quick 1999; Roberts 2001; Reller 2003-i; Chiller 2004; Clasen 2004b; Clasen 2004c; Crump 2004-i; Doocy 2004); nine presented results only for all ages or older age groups (Aziz 1990; Conroy 1996; Xiao 1997; Conroy 1999; Colford 2002; Quick 2002; Luby 2004a-i; Luby 2004b-i; Lule 2005); and 10 presented results only for children under five years (or a subgroup thereof) (Alam 1989; Austin 1993-i; Mahfouz 1995; URL 1995-i; Messou 1997; Handzel 1998; Gasana 2002; Jensen 2003; du Preez 2004; Garrett 2004).

Most of the trials adjusted raw data to account for possible covariates, including age (Conroy 1996; Handzel 1998; Conroy 1999; Reller 2003-i; Clasen 2004b; Clasen 2004c; Luby 2004a-i; Lule 2005), seasonality (Aziz 1990; Messou 1997; Jensen 2003; Reller 2003-i), sex (Conroy 1996; Conroy 1999; Reller 2003-i), sanitation or hygiene practices (Alam 1989; Jensen 2003; Lule 2005), area of residence (Conroy 1996; Conroy 1999), household income or proxies thereof (Handzel 1998; Reller 2003-i), education (Alam 1989), age and occupation of the head of household (Alam 1989; Handzel 1998), maternal literacy (Reller 2003-i), number of participants in the household (Semenza 1998) or absent there from (Aziz 1990), or other variables associated with the household environment and participant behaviour (Roberts 2001). Most trials of interventions at the household level also used statistical methods to adjust their results for repeated episodes of diarrhoea by the same participant (Quick 1999; Quick 2002; Clasen 2004b; Clasen 2004c; Lule 2005) or for clustering within the household - the four trials that did not adjust for clustering may receive excess weight in meta-analysis due to artificial precision (Kirchhoff 1985; Austin 1993-i; Mahfouz 1995; URL 1995-i).

\section{Randomized controlled trials (Table I)}

The allocation sequence was generated using an 'adequate' method in 12 of the 19 trials, 'inadequate' in four, and 'unclear' in three. The method of allocation concealment was 'adequate' in 15 trials and 'inadequate' in the other four. Only three trials used blinding (Kirchhoff 1985; Austin 1993-i; Colford 2002;); the others followed an open design. One of the principal objectives of Colford 2002 was to assess the effectiveness of its blinding methodology; it therefore provides the most comprehensive analysis of these issues. Colford 2002 used a sham water filter that even the installer could not know was not effective. Austin 1993-i and Kirchhoff 1985, which were assessing the effectiveness of home-based chlorination, provided placebos to control households. While one trial suggests ethical and other reasons for its decision not to blind the trial (Clasen 2004c), it is not clear why so few of the householdbased interventions failed to use a placebo control.

Twelve of the trials used 'adequate' methods to generate the allocation sequence and conceal allocation, and eight of these were also 'adequate' for the inclusion of all randomized participants. Only Colford 2002 met all criteria for methodological quality including blinding, though Austin 1993-i failed only by falling 0.6\% short of the follow-up criterion.

\section{Quasi-randomized controlled trials (Table 2)}

Of the 11 trials, eight were 'adequate' for the comparability of characteristics between intervention and control groups, two were 'inadequate', and one was 'unclear'. Except for Gasana 2002, which was 'unclear', all the trials met the contemporaneousness of data collection criterion.

\section{Note regarding comparisons of randomized and quasi-randomized controlled trials}

The methods of this review established separate and customary criteria for assessing the risk of bias in trials. While these criteria may be used for purposes of comparing the risk of bias in trials of the same design, we urge caution with respect to comparing randomized with quasi-randomized controlled trials. A randomized controlled trial that fails to meet certain quality criteria may nevertheless be of greater methodological rigour than one using quasi-randomization that meets its applicable criteria.

\section{Effects of interventions}

\section{Note regarding meta-analysis}

Some of the meta-analyses include the following trials, which, by comparing multiple intervention groups with a single control

\section{Risk of bias in included studies}


group, count the controls more than once in violation of the principles of meta-analysis and provide overly precise confidence intervals widths around pooled estimates: URL 1995-i; Reller 2003-i; Crump 2004-i; Luby 2004a-i; and Luby 2004b-i.

\section{Diarrhoea episodes}

\section{I.I. Overall effectiveness}

The data suggest that interventions to improve the microbial quality of water are effective in preventing diarrhoea among people of all ages and young children. However, not all pooled measures of effect are statistically meaningful, and most results are characterized by substantial heterogeneity. None of the 38 trials found a statistically significant increase in diarrhoea with the intervention. There were statistically significantly fewer diarrhoea episodes with the intervention when the data were pooled using rate ratios (all ages $0.73,95 \%$ CI 0.63 to $0.85,10$ trials, Analysis 1.1.1; under fives $0.78,95 \%$ CI 0.65 to $0.94,6$ trials, Analysis 1.2.1) and risk ratios (all ages $0.45,95 \%$ CI 0.33 to $0.62,7$ trials, Analysis 2.1.1; under fives $0.54,95 \%$ CI 0.43 to 0.69, 5 trials, Analysis 2.2.1). Both analyses included a comparison of a single control arm against two interventions from one trial, Luby 2004a-i in Analysis 1.1 (all ages) and URL 1995-i in Analysis 2.1 and Analysis 2.2 (all ages and children under five, respectively), which means that the statistical significance of these analyses must be interpreted with caution.

There was no statistically significant difference in the pooled longitudinal prevalence ratios between the water treatments and the controls for the trials reporting data for all ages (11 trials, Analysis 3.1.1) or children less than five years old (11 trials, Analysis 3.2.1). However, excluding Doocy 2004, which reported a very large and statistically significant effect for both age groups and is a possible outlier, the results favoured the intervention both for all ages (0.68, $95 \%$ CI 0.55 to $0.84,10$ trials) and the under fives $(0.74$, $95 \%$ CI 0.65 to $0.85,10$ trials).

The pooled odds ratios were statistically significantly in favour of the water treatment (at the household level; no trials using this statistical outcome investigated treatment at source) for nine trials reporting data for all ages $(0.68,95 \%$ CI 0.59 to 0.79 , Analysis 4.1.1) and the six trials reporting data for children under five years $(0.70,95 \%$ CI 0.50 to 0.99 , Analysis 4.2.1). Caution should be taken when interpreting the statistical significance of both results because a single control arm from one trial, Reller 2003-i, is compared against four interventions.

Only one trial reported means ratios. It reported statistically significant results in favour of household water treatment for people of all ages $(0.57,95 \%$ CI 0.52 to 0.62 , Analysis 5.1) and for children under five years $(0.75,95 \%$ CI 0.65 to 0.86 , Analysis 5.2$)$.

\section{I.2. Exploration of heterogeneity: subgroup analyses}

\subsubsection{Interventions at the water source}

The six trials reporting on interventions at the water source used three different effect measures. There was no difference in diarrhoea episodes when measured using rate ratios (all ages, 4 trials, Analysis 1.1.2; under fives, 3 trials, Analysis 1.2.2). The interventions were favoured in the trials that reported a risk ratio (all ages $0.45,95 \%$ CI 0.43 to $0.47,1$ trial, Analysis 2.1 .2 ) or a longitudinal prevalence ratio (all ages $0.56,95 \%$ CI 0.37 to $0.84,1$ trial, Analysis 3.1.2; under fives 0.63 , $95 \%$ CI 0.49 to $0.81,1$ trial, Analysis 3.2.2).

\subsubsection{Interventions in the household}

Thirty-two trials reported on household-based interventions, which included chlorination, filtration, solar disinfection, combined flocculation and disinfection, and improved storage. Overall, the household interventions significantly reduced diarrhoea episodes amongst people of all ages and in children under five years as measured with rate ratios (all ages $0.56,95 \%$ CI 0.42 to $0.74,6$ trials, Analysis 1.1.3; under fives $0.42,95 \%$ CI 0.19 to $0.95,3$ trials, Analysis 1.2.3), risk ratios (all ages $0.43,95 \%$ CI 0.27 to 0.70 , 6 trials, Analysis 2.1.3; under fives $0.54,95 \%$ CI 0.43 to $0.69,5$ trials, Analysis 2.2.2), odds ratios (all ages $0.68,95 \%$ CI 0.59 to 0.79 , 9 trials, Analysis 4.1.2; under fives $0.70,95 \%$ CI 0.50 to $0.99,6$ trials, Analysis 4.2.2), and means ratios (all ages 0.57, $95 \%$ CI 0.52 to $0.62,1$ trial, Analysis 5.1; under fives $0.75,95 \% \mathrm{CI}$ 0.65 to $0.86,1$ trial, Analysis 5.2). The longitudinal prevalence ratios (Analysis 3.1.3 and Analysis 3.2.3) only reached statistical significance when a possible outlier, Doocy 2004, was excluded from the analysis for all age groups $(0.70,95 \%$ CI 0.56 to 0.88 , 9 trials) and for the under fives $(0.76,95 \%$ CI 0.66 to $0.88,9$ trials). As mentioned above, caution must be taken when interpreting these results because some of the analyses use the control arms more than once (URL 1995-i; Reller 2003-i; Luby 2004a-i).

\section{Household chlorination}

Sixteen trials reported on household-based chlorination, and the overall results varied with the measure of effect and age group. Chlorination was statistically significantly better than the control among all age groups when measured using rate ratios ( 4 trials, Analysis 1.1.4), though this pooled estimate uses the control arm of one trial twice (Luby 2004a-i), risk ratios (3 trials, Analysis 2.1.4), and means ratio (1 trial, Analysis 5.1.3); and children under five using risk ratios (2 trials, Analysis 2.2.3) and means ratio (1 trial, Analysis 5.2.3). There was no statistically significant advantage for people all ages when measured with longitudinal prevalence ratios (5 trials, Analysis 3.1.4) and odds ratios (3 trials, Analysis 4.1.3); 
or for children under five as measured with rate ratios (2 trials, Analysis 1.2.4), longitudinal prevalence ratios (5 trials, Analysis 3.2.4), and odds ratios (2 trials, Analysis 4.2.3).

\section{Household filtration}

Of the six trials that reported on household-based filtration, two used rate ratios (Analysis 1.1.5 and Analysis 1.2.5), two arms of a single trial used risk ratios (single control group used twice in Analysis 2.1.5 and Analysis 2.2.4; URL 1995-i), and two used odds ratios (Analysis 4.1.4 and Analysis 4.2.4). All estimates for people of all ages and children under five were statistically significantly in favour of the intervention.

\section{Household solar disinfection}

Solar disinfection was statistically significantly better than the control for reducing diarrhoea episodes in people of all ages ( 2 trials, odds ratios, Analysis 4.1.5). Since the controls also received bottles that may have provided some protection against diarrhoea by means of improved storage, the measure of effect in these trials may understate the effectiveness of the intervention.

\section{Household combined flocculation and disinfection}

Seven trials reported on the effectiveness of combined flocculation and disinfection. Pooled estimates of the five trials reporting longitudinal prevalence ratios found no statistically significant difference in the number of diarrhoea episodes compared with the control, either for people of all ages (Analysis 3.1.5) or for children under five (Analysis 3.2.5). Excluding Doocy 2004, which has been identified as a possible outlier, changes the effect to become statistically significantly in favour of the intervention, both for all ages $(0.60,95 \%$ CI 0.43 to 0.83$)$ and for the under fives $(0.66,95 \%$ CI 0.43 to 0.76 ), though the meta-analyses use the control arm of Luby $2004 \mathrm{~b}-\mathrm{i}$ twice. The two trials using odds ratios reported a statistically significant reduction in diarrhoea episodes for people of all ages (Analysis 4.1.6) and not the under fives (Analysis 4.2.5), though these estimates must once again be interpreted with caution as they are arms of a single trial with only one control group (Reller 2003-i).

\section{Household improved storage}

The one trial that involved improved storage found no significant difference in diarrhoea episodes, measured with risk ratios, for people of all ages (Analysis 2.1.6) or the under fives (Analysis 2.2.5) (Roberts 2001).

\subsubsection{Compliance with household interventions}

We divided the trials reporting on compliance between those reporting compliance of less than $50 \%$ and $50 \%$ or greater. In both the trials reporting risk ratios (Analysis 6.1) and those reporting odds ratios (Analysis 7.1), the effect of the intervention was stronger in the group with higher compliance. This was especially true for trials reporting odds ratios $(<50 \% 0.80,95 \%$ CI 0.71 to $0.89,4$ trials, Analysis $7.1 .1 ; \geq 50 \% 0.40,95 \%$ CI 0.28 to $0.57,3$ trials, Analysis 7.1.2). This must be interpreted with caution since the Reller 2003 trial compares a single control arm against four interventions.

Compliance could help explain the disparity in results between the same interventions in different circumstances. For example, for the combined flocculant and disinfectant product, Doocy 2004 reported a longitudinal prevalence ratio of 0.12 (95\% CI 0.11 to 0.13 ) in a programme where compliance was $95 \%$, while Reller 2003-i reported an odds ratio of 0.79 (95\% CI 0.63 to 0.99) from a programme where compliance reached only $27 \%$. At the same time, it cannot be the only explanation: Crump 2004-i reported a longitudinal prevalence ratio of 0.83 (95\% CI 0.67 to 1.03 ) from an intervention in which compliance was also fairly high (86\%).

\subsubsection{Ambient water quality}

In these comparisons (Analysis 8.1 to Analysis 11.1), we treated each of the indicators of microbial water quality (coliforms or a subset thereof) homologously and grouped them on a log scale that corresponds to the WHO risk category (WHO 1993) that ranges from 'complying' (0 CFU/100 mL) to 'high or very high risk' (> $100 \mathrm{CFU} / 100 \mathrm{~mL}$ ). The results provide little evidence that the effectiveness of the interventions is associated with ambient water quality.

\subsubsection{Water quantity and access}

Few trials used the same measure of effect for reporting on water quantity. Using longitudinal prevalence ratios (Analysis 12.1), there was no statistically significant difference in the effectiveness of the interventions based where water was reported to be 'sufficient' ( 1 trial) or 'insufficient' ( 4 trials) according to established criteria (Sphere Project 2004). No trials reported access to a water source to be 'insufficient'.

\subsubsection{Water supply}

Pooling of results based on 'improved' or 'unimproved' water supply levels, according to established criteria (WHO/UNICEF 2000), was possible for nine trials reporting rate ratios (Analysis 13.1), six trials reporting risk ratios (Analysis 14.1), 11 trials reporting longitudinal prevalence ratios (Analysis 15.1), and nine trials reporting odds ratios (Analysis 16.1). Overall, these results provide little evidence that the effectiveness of the interventions 
is associated with water supply level, particularly when excluding Doocy 2004, the possible outlier. It is noteworthy, however, that the pooled estimates show a statistically significant effect in favour of the interventions even in settings without improved water supply.

\subsubsection{Sanitation}

Some trials reported on sanitation levels as 'improved' or 'unimproved' using the established criteria (WHO/UNICEF 2000). We were able to pool these results for seven trials reporting rate ratios (Analysis 17.1), four trials reporting risk ratios (Analysis 18.1), and seven trials reporting longitudinal prevalence ratios (Analysis 19.1). These results provide little evidence that the effectiveness of the interventions is associated with sanitation level. At the same time, they suggest that the interventions are effective in preventing diarrhoeal disease even in settings in which sanitation has not yet been improved, even when excluding Doocy 2004, a possible outlier that is responsible for much of the heterogeneity in the results of trials reporting longitudinal prevalence ratios.

\subsubsection{Water quality only versus compound environmental interventions}

In general, there is no clear evidence that water quality interventions are more effective in preventing diarrhoea when combined with any of the additional interventions: hygiene promotion; separate vessel for water treatment or storage, or both; or improvements in sanitation or water supply (Analyses 20 to 23).

\subsubsection{Trial methodological quality (risk of bias)}

In the randomized controlled trials (Analysis 24 to Analysis 27), the interventions were generally more effective among the higher quality trials with respect to allocation sequence, allocation concealment, and inclusion of randomized participants in the analysis. Only four trials used double blinding (Kirchhoff 1985; Austin 1993-i; Austin 1993-ii; Colford 2002), and, significantly, none of them (and hence, none of the pooled estimates thereof) found a statistically significant protective effect from the water quality intervention.

In the quasi-randomized controlled trials (Analyses 28 and 29), the interventions appear more effective amongst those that met the review's criteria for methodological quality. However, since few trials actually failed such criteria, these subgroup analyses did not suggest that study quality is an explanation of the heterogeneity of results.

\subsubsection{Potential outlier}

Forest plots of the measures of effect from all 38 trials suggest at least one possible outlier. By definition, an outlier is an observation that differs so widely from the rest of the data as to suggest a possible error or that the observation comes from a differently population (Last 2001). Doocy 2004, a randomized controlled trial that lasted 12 weeks, studied a combined flocculant and disinfectant water treatment for displaced persons living in temporary shelters in a Liberian camp. The intervention was exceptionally protective (RR $0.12,95 \%$ CI 0.11 to 0.13 ). While data supplied suggest the trial to be well designed and to meet this review's quality criteria, it has not yet been published and thus subjected to peer review. It seems possible that the population and conditions presented in the camp may not be strictly comparable with those of the other studies comprising this review.

\section{Death}

Two trials reported on death. Crump 2004-i reported a risk ratio of $0.53(\mathrm{P}=0.052)$ for the flocculant and disinfectant arm of a household-based water treatment and $0.61(\mathrm{P}=0.108)$ for the disinfectant-only arm. No physical or verbal autopsies were performed, and no association between deaths and diarrhoea was established. Messou 1997, which involved a combination of source water improvement with an oral rehydration intervention and hygiene instruction, reported an $85 \%$ reduction (from $27 \%$ to $4 \%$ ) in the proportion of deaths related to diarrhoea in the villages with the intervention $(\mathrm{P}=0.04)$ compared with no reduction in control villages. That trial also reported an $85 \%$ reduction (from $5.3 \%$ to $0.8 \%)$ in the death rate associated with diarrhoea morbidity among intervention villages $(\mathrm{P}=0.04$ ) with no correspondingly decline in control villages. We emphasize that neither trial was primarily designed to investigate the impact of the intervention on death, and that such studies may require important differences in study design, sample size, and other parameters.

\section{Adverse events}

No trial reported adverse events from the interventions.

\section{Publication bias}

Figure 1 presents a funnel plot of the estimate of effect of the trials and the standard error of such estimate of effect (reflecting the study size). The asymmetrical shape of such funnel plot is suggestive of publication bias. It is noted, however, that funnel plot asymmetry may also be due to clinical and methodological heterogeneity. Since we found substantial evidence of such heterogeneity, we cannot conclude that the funnel plot demonstrates evidence of publication bias in this case. 
Figure I. Funnel plot to explore publication bias

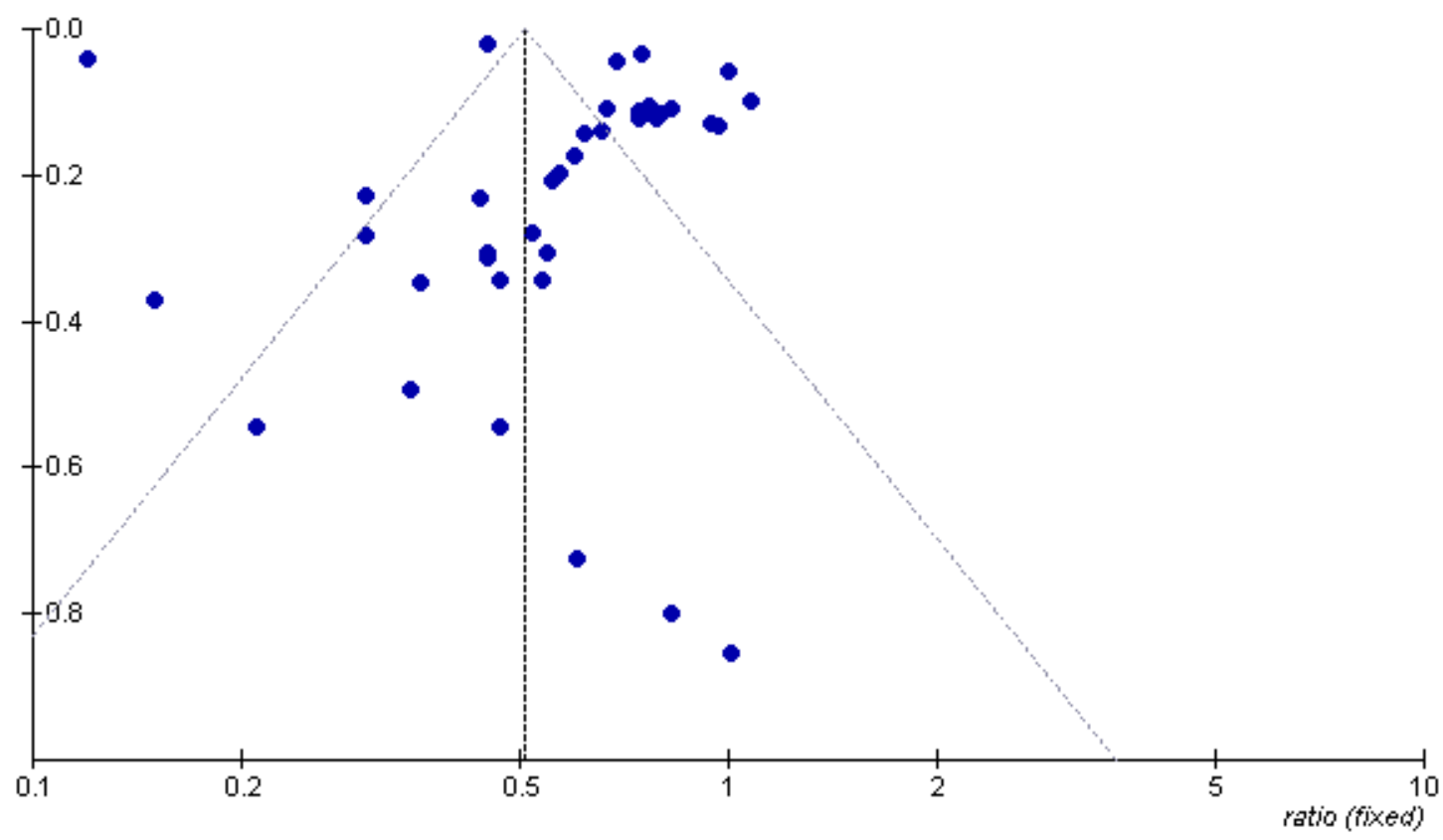

\section{Sensitivity analysis}

We endeavoured to conduct a sensitivity analysis to explore the effect of combining randomized controlled trials and quasi-randomized controlled trials in a meta-analysis and to investigate the effect of including trials that were not adjusted for clustering. However, as all source-based interventions were investigated in the quasirandomized controlled trials, it was not possible to compare the trials on the basis of point of intervention or type of intervention if the quasi-randomized controlled trials are excluded. Comparisons based on subgroups do not include pooled estimates. Similarly, while 19 of 24 trials involving household-based interventions adjusted for clustering, none of the six trials with analysable data from source interventions did so. Accordingly, no comparison on this criterion was possible.

\section{DISCUSSION}

This review assesses the impact of interventions to improve microbial water quality on diarrhoeal disease. Thirty trials covering 38 interventions and more than 53,000 participants met the review's inclusion criteria. Substantial clinical and methodological heterogeneity among the trials allowed only limited pooling of the results in meta-analyses. Our focus, therefore, has been largely descriptive. Where appropriate, however, we have tried to interpret the evidence, while at the same time noting some of the issues that necessarily limit this.

\section{Effectiveness}

Interventions to improve the microbiological quality of drinking water are protective against diarrhoea, both for people of all ages and for the vulnerable population of children less than five years old. But the evidence is not absolute and the actual level of effectiveness of such interventions varies considerably. Underlying clinical heterogeneity appears to be responsible for the heterogeneity. The aetiology and epidemiology of diarrhoea is complex and variable, and even the portion of diarrhoea that is waterborne is probably different at different times and places (Luby 2004). Nevertheless, the subgroup analyses provide possible explanations for the differences.

First, household interventions, though also varying considerably in results, are considerably more effective at preventing diarrhoea than interventions at the water source. The reviews from Esrey and colleagues (Esrey 1985; Esrey 1991a) included only studies investigating improvements of water quality at the source, not at the household level. The $15 \%$ to $17 \%$ median reduction in diarrhoea that they reported is within the range of our findings for source-based interventions. The effectiveness of household-based interventions, on the other hand, is significantly greater than those at the source, and is comparable to certain other environmental 
interventions to prevent diarrhoea, such as improved sanitation, hygiene (hand washing with soap), and improved water supply (Curtis 2003; Fewtrell 2005). Among household interventions, there is some evidence that filtration offers the most consistent and effective results. It is important to note, however, that none of the source-based interventions included in this review involved pipedin household connections. Thus, the effectiveness of the source systems described herein should not be generalized to reticulated systems.

Second, there is some evidence that effectiveness is enhanced by compliance with the intervention. While this may appear intuitive, it suggests a dose-response association between compliance and results that provides additional evidence of a causal relationship. It also implies the need to address compliance as part of any intervention to improve water quality. This may involve both the inherent acceptability and appeal of the hardware components of the intervention as well as programmatic support to increase utilization. To the extent that interventions are deployed at the household rather than community level, this also implies the need to address compliance during routine activities outside the home such as school and work.

Third, the evidence does not suggest that an 'improved' supply of water (ie household connection, public standpipe, borehole, protected dug well, protected spring, rainwater collection) is essential for water quality interventions to prevent diarrhoea. This finding affirms the WHO's strategy to pursue household water treatment and safe storage as a means of accelerating the health gains of safe drinking water, even though it may not reduce the 1.1 billion currently without access to improved water supplies.

Fourth, water quality interventions appear to be effective in preventing diarrhoea regardless of whether they are deployed in settings where sanitation is 'improved' (ie connection to a public sewer or septic system, pour-flush latrine, simple pit latrine, or ventilated improved pit latrine) or 'unimproved'. This is in contrast to conclusions that interventions to improve water quality are effective only where sanitation has already been addressed (Esrey 1986; VanDerslice 1995).

The subgroup analyses did not demonstrate that the effectiveness of a water quality intervention to prevent diarrhoea is enhanced by adding hygiene instruction, a separate vessel to treat or store water, or by improving sanitation or water supply. This is consistent with our finding that the effectiveness of a water quality intervention does not depend on the baseline conditions in regard to other environmental parameters that are associated with diarrhoea. At the same time, it implies that the cost and effort of combining the water quality intervention with improved hygiene, water storage, water supply, or sanitation may not be justified on the basis of the a synergistic effect on diarrhoeal disease.

Ultimately, the value of water quality interventions in preventing diarrhoeal disease depends not only on their effectiveness but also on their affordability, acceptability, sustainability and scalability within a vulnerable population. Comprehensive cost-effectiveness and cost-benefit analyses will help establish the priority that should be attached to water quality interventions by the public sector and non-governmental organizations. Finally, since household interventions appear especially effective, the private sector, which has particular capacity for addressing the needs of householders, should be explored as a potential source for developing effective, low-cost water treatment interventions on a wide scale.

\section{Trial methodological quality (risk of bias)}

The trials with good methodological quality show a greater overall level of effectiveness than those that do not. However, this review included both randomized and quasi-randomized controlled trials, and by necessity, employed different quality criteria for each. Because household-based interventions tended to be randomized controlled trials design while source-based interventions exclusively used quasi-randomization, there is an important bias that may affect the comparison. If, as suggested, the criteria for methodological quality for the two trial designs are not strictly comparable, this bias would affect the comparison of household versus source water interventions. With four criteria for assessing the quality of randomized controlled trials, conclusions about methodological quality could also lead to an unintentional bias. For example, among the three trials that used blinding, only one was deemed adequate on even two other quality criteria. The application of these criteria would thus skew the results against blinded trials.

Only three of 19 randomized controlled trials were blinded, and in each case the intervention had no statistically significant protective effect. This must give pause to any definitive conclusion about the potential value of water quality interventions in the prevention of diarrhoea. The authors of each of these trials suggested possible explanations for their findings. Colford 2002 was the only trial conducted in a developed country setting, and the water there already complied with US standards. Kirchhoff 1985, though a pioneering trial of a potentially important household intervention, had a study population of only 112 persons (smallest of all the included trials) and was rated low on three other criteria of methodological quality. Austin 1993-i also suggested possible methodological issues and used dilute sodium hypochlorite in the control group, an approach that probably improved their water quality thus resulting in an understatement of the intervention's effectiveness. While one trial, Clasen 2004c, cited ethical and other reasons for the decision not to blind the trial, it is not clear why so few of the household-based interventions failed to use placebo controls. Future trials should take steps to address this issue by using blinding design wherever possible.

\section{Trial design and methodology}

Subgroup analyses suggest that there are clinical sources of heterogeneity based on the intervention point and also among the dif- 
ferent household interventions. However, given the heterogeneity within most of these subgroups, we cannot rule out the possibility that it may be due to differences in the trials' design and methodology.

The design of the trials is not independent of the type of intervention. All six trials involving interventions at the source used quasi-randomization, while 19 of 23 point-of-use interventions were randomized controlled trials. Although this mainly reflects the difficulty in randomizing users of source water interventions, the skewing of design between the two types of interventions could possibly account for differences in the results observed.

The length of the trials was not independent of the point of intervention. The median duration of trials of interventions at the source was more than six times longer than those involving interventions at the household level. Four of six such source-based intervention trials were of three years' duration or longer, while only three of the 32 household-based interventions lasted even one year. Seasonality plays a major role in diarrhoea incidence (Blum 1983), and failure to include at least 12 months' data on diarrhoea may overstate or understate the annual burden of disease in the underlying population and correspondingly influence the measure of effect.

Compliance with the intervention was probably not independent of the point of intervention. Household-based interventions all require some effort on the part of the participants to treat their water, to have treated water consistently available, to avoid recontamination, and to refrain from drinking from untreated sources. Each of these conditions creates an opportunity for non-compliance. Most source-based interventions, on the other hand, extended to the household's entire water supply without any additional compliance steps on the part of the intervention population. Thus, compliance was probably higher among groups using source-based rather than household-based interventions. If compliance is naturally lower among household-based interventions, than this bias may be a natural concomitant. But if compliance can be improved (as it apparently was in some trials), then the higher natural compliance with source interventions may overstate their effectiveness compared to interventions at home.

Participants are more conscious of interventions carried out in their home than those at a distant water source or treatment works. This could lead to bias in trials that are not blinded. Courtesy bias (the tendency of participants who know they are in the intervention group to overstate the effect to please the investigator) and Hawthorne effect (the effect, usually positive, of being under investigation generally) may conspire to overstate or understate the effectiveness of the interventions covered by this review. This is particularly true for the non-blinded trials of household-based interventions that were often research-driven with perhaps more intensive investigator presence.

The availability of water is also an important factor. Interventions at the source are frequently designed primarily to improve the water quantity and availability rather than quality. On the other hand, such improvements in water supply may be a separate and possibly more significant contributor to health than water quality. In the case of the household-based interventions, most appeared to have been conducted in settings with sufficient water, which may mean that these results cannot be generalized to locations where water supplies are inadequate.

The interventions have varying levels of microbiological performance against different types of diarrhoegenic organisms, particularly under different water conditions. In a setting in which diarrhoea was mainly viral, ceramic filters would be only marginally protective. Similarly, where Cryptosporidium or another chlorineresistant agent is an important cause of diarrhoea, chlorination may provide little if any protection. Even within these categories of interventions, there are important differences in microbiological performance. For example, the filtration subgroup includes ceramic filters that are not generally effective against viruses, and reverseosmosis filters that are. Similarly, while the sodium hypochlorite used in most chlorination studies has certain antimicrobial capacity, other chlorine studies used mixed oxidants (Quick 1999) that have been shown to have broader biocidal effect (Venczel 1997). Since none of the trials continuously monitored the full range of diarrhoea-causing pathogens present in the drinking water of the study population and few trials attempted to determine clinically the apparent causes of diarrhoea in such population, it is difficult to compare the interventions based on their microbiological performance. This difference in field performance also illustrates another potential flaw in pooling for analysis seemingly similar interventions such filtration and chlorination.

Many of the trials reported results on selected age groups, and not on all ages of persons who would have been affected by the intervention. It is common for research on diarrhoeal disease to specifically target children less than five years of age, a group that is particularly vulnerable to diarrhoea, and many of the trials did provide data for this group. Many others, however, reported results only for a subset of this group, or for some other segment of the population. In most cases, it appears that results were reported for the full population on which data were collected. It is possible, that by omitting a portion of the population affected by the intervention, the design or reporting of results is a source of bias. Finally, it appears that many if not most of the trials were undertaken primarily for the purpose of investigating the effectiveness of the intervention, and not as an assessment of an ongoing programme. This seems particularly true of the household interventions. While investigators often took special steps to minimize the effect that such a research focus may have had on the study results, the continuous onsite participation of investigators, many of whom were foreign to the study settings, in implementing and assessing the intervention could be a source of possible bias. It may also raise questions about whether the results obtained would be representative of the effectiveness of the interventions outside a research context. Future trials should include assessments of ongoing programmes implemented outside a research context. 


\section{AUTHORS' CONCLUSIONS}

\section{Implications for practice}

Interventions to improve the microbiological quality of drinking water, particularly at the household level, are more effective in preventing diarrhoea in endemic settings than previously reported. Household interventions may be as effective at preventing diarrhoea as other environmental approaches, such as improved sanitation, hygiene (hand washing with soap), and improved water supply. Thus they should be strongly encouraged, particularly because of evidence that they are cost-effective and that the target population may in fact be willing to pay for all or a portion of their cost.

Our results also make clear, however, that single estimates of the effectiveness of water quality interventions against endemic diarrhoea, appealing as they may be to policy makers, donors, and programme implementers, are not warranted by the evidence. Studies have shown a wide range of results, including a number of trials where no statistically significant protective effect was observed.

\section{Implications for research}

Rigorously conducted randomized controlled trials that compare various approaches to improving drinking water quality will help clarify the potential for water quality interventions to prevent endemic diarrhoea. It is particularly important that such trials be blinded, if possible, not only for the methodological reasons that favour blinded trials generally but also because of the mixed effectiveness achieved in blinded studies of water quality interventions to date. There is also a need for longer-term studies in programmatic (non-research driven) settings, especially on householdbased interventions. The suggestion, first observed by Fewtrell 2005 , that water quality interventions are effective even in the absence of improved sanitation, and that water quality interventions are not materially enhanced by compounding them with improved hygiene, sanitation, water supply or storage, should also be verified in a rigorous trial since they also challenge previous conclusions. Our results also demonstrate a need for more trials on the extent to which these water quality interventions affect mortality and not just morbidity. The difference in results between source and household interventions, and the range of results among the various core household approaches themselves, suggest the need to understand better how water quality interventions with similar microbiological performance nevertheless may result in different levels of effectiveness in preventing diarrhoea. This also implies the need to explore and assess the extent to which new technologies for improving water quality may be suitable for use among remote and low-income settings where the burden of diarrhoeal disease is highest. Differences in programmatic approaches to optimize the adoption and long-term utilization of these interventions should also be investigated.

\section{ACKNOWLEDGEMENTS}

We gratefully acknowledge the following people for their research, advice, assistance and other valuable contributions: Greg Allgood, Jamie Bartram, Joseph Brown, Jack Colford, John Crump, Tom Chiller, Val Curtis, Shannon Doocy, Lorna Fewtrell, Carrol Gamble, Bruce Gordon, Stephen Gundry, Bruce Keswick, Steve Luby, Rob Quick, Mark Sobsey, Sara Thomas, and James Wright. We also appreciate the assistance and help provided by other members of the Cochrane Infectious Diseases Group, and by the referees of both this review and the protocol.

The editorial base for the Cochrane Infectious Diseases Group is funded by the UK Department for International Development (DFID) for the benefit of developing countries.

\section{R E F E R E N C E S}

\section{References to studies included in this review}

Alam 1989 \{published data only\}

Alam N, Wojtyniak B, Henry FJ, Rahaman MM. Mothers' personal and domestic hygiene and diarrhoea incidence in young children in rural Bangladesh. International Journal of Epidemiology 1989;18(1):242-7.

Austin 1993-i \{unpublished data only\}

Austin CJ. Investigation of in-house water chlorination and its effectiveness for rural areas of the Gambia [dissertation]. New Orleans: Tulane University School of Public Health and Tropical Medicine, 1993.

Austin 1993-ii \{unpublished data only\}

Austin CJ. Investigation of in-house water chlorination and its effectiveness for rural areas of the Gambia [dissertation]. New
Orleans: Tulane University School of Public Health and Topical Medicine, 1993.

\section{Aziz 1990 \{published data only\}}

* Aziz KM, Hoque BA, Hasan KZ, Patwary MY, Huttly SR, Rhaman MM, et al.Reduction in diarrhoeal diseases in children in rural Bangladesh by environmental and behavioural modifications. Transactions of the Royal Society of Tropical Medicine and Hygiene 1990;84(3):433-8. Hasan KZ, Briend A, Aziz KM, Hoque BA, Patwary MY, Huttly SR. Lack of impact of a water and sanitation intervention on the nutritional status of children in rural Bangladesh. European Journal of Clinical Nutrition 1989;43 (12):837-43.

Henry FJ, Huttly SR, Patwary Y, Aziz KM. Environmental sanitation, food and water contamination and diarrhoea in 
rural Bangladesh. Epidemiology and Infection 1990;104(2): 253-9.

Chiller 2004 \{published and unpublished data\}

* Chiller TM, Mendoza CE, Lopez MB, Alvarez M, Hoekstra RM, Keswick BH, et al.Reducing diarrhea in Guatemalan children: a randomized controlled trial of a flocculant-disinfectant for drinking water. Data on file. Chiller TM, Mendoza CE, Lopez MB, Alvarez M, Hoekstra RM, Keswick BH, et al.Reducing diarrhoea in Guatemalan children: randomized controlled trial of flocculantdisinfectant for drinking-water. Bulletin of the World Health Organization 2006;84(1):28-35.

Clasen 2004b \{published and unpublished data\} * Clasen T, Brown J, Collin S. Preventing diarrhoea with household ceramic water filters: an assessment of a pilot intervention in rural Bolivia. Data on file.

Clasen TF, Brown J, Collin SM. Preventing diarrhoea with household ceramic water filters: Assessment of a pilot project in Bolivia. International Journal of Environmental Health Research 2006;16(3):231-9.

\section{Clasen 2004c \{published data only\}}

Clasen TF, Brown J, Collin S, Suntura O, Cairncross S. Reducing diarrhea through the use of household-based ceramic water filters: a randomized, controlled trial in rural Bolivia. American Journal of Tropical Medicine and Hygiene 2004;70(6):651-7.

\section{Colford 2002 \{published data only\}}

Colford JM Jr, Rees JR, Wade TJ, Khalakdina A, Hilton

JF, Ergas IJ, et al.Participant blinding and gastrointestinal illness in a randomized, controlled trial of an in-home drinking water intervention. Emerging Infectous Diseases 2002;8(1):29-36.

Conroy 1996 \{published data only\}

Conroy RM, Elmore-Meegan M, Joyce T, McGuigan KG, Barnes J. Solar disinfecion of drinking water and diarrhoea in Maasai children: a controlled field trial. Lancet 1996;348 (9043):1695-7.

Conroy 1999 \{published data only\} Conroy RM, Meegan ME, Joyce T, McGuigan K, Barnes J. Solar disinfection of water reduces diarrhoeal disease: an update. Archives of Disease in Childhood 1999;81(4):337-8.

Crump 2004-i \{published and unpublished data\}

* Crump JA, Otieno PO, Slutsker L, Keswick BH, Rosen DH, Hoekstra RM, et al.A cluster randomized controlled trial of household-based flocculant-disinfectant drinking water treatment for diarrhea prevention in the setting of highly turbid source water in rural western Kenya. Data on file.

Crump JA, Otieno PO, Slutsker L, Keswick BH, Rosen $\mathrm{DH}$, Hoekstra RM, et al.Household based treatment of drinking water with flocculant-disinfectant for preventing diarrhoea in areas with turbid source water in rural western Kenya: cluster randomised controlled trial. BMJ 2005;331 (7515):478-83.

\section{Crump 2004-ii \{unpublished data only\}}

Crump JA, Otieno PO, Slutsker L, Keswick BH, Rosen $\mathrm{DH}$, Hoekstra RM, et al.A cluster randomized controlled trial of household-based flocculant-disinfectant drinking water treatment for diarrhea prevention in the setting of highly turbid source water in rural western Kenya. Data on file.

Doocy 2004 \{unpublished data only\}

Doocy S. Point of use water treatment in the emergency context: a randomized intervention trial in Liberia. Data on file.

du Preez 2004 \{unpublished data only\} du Preez M, Moyo S. AQUAPOL--South African filter trial. Data on file.

\section{Garrett 2004 \{unpublished data only\}}

Garrett V. Preventing diarrhoea in a high-risk rural Kenyan population with an inexpensive point-of-use water quality intervention. Data on file.

\section{Gasana 2002 \{published data only\}} Gasana J, Morin J, Ndikuyeze A, Kamoso P. Impact of water supply and sanitation on diarrheal morbidity among young children in the socioeconomic and cultural context of Rwanda (Africa). Environmental Research 2002;90(2): $76-88$.

Handzel 1998 \{published and unpublished data\}

* Handzel T. The effect of improved drinking water quality on the risk of diarrhoeal disease in an urban slum of Dhakar, Bangladesh: a home chlorination intervention trial [dissertation]. Chapel Hill (NC): University of North Carolina at Chapel Hill, 1998.

Sobsey MD, Handzel T, Venczel L. Chlorination and safe storage of household drinking water in developing countries to reduce waterborne disease. Water Science and Technology 2003;47(3):221-8.

\section{Jensen 2003 \{published data only\}}

Jensen PK, Ensink JH, Jayasinghe G, van der Hoek W, Cairncross S, Dalsgaard A. Effect of chlorination of drinking-water on water quality and childhood diarrhoea in a village in Pakistan. Journal of Health, Population, and Nutrition 2003;21(1):26-31.

\section{Kirchhoff 1985 \{published data only\}}

Kirchhoff LV, McClelland KE, Do Carmo Pinho M, Araujo JG, De Sousa MA, Guerrant RL. Feasibility and efficacy of in-home water chlorination in rural North-eastern Brazil. Journal of Hygiene 1985;94(2):173-80.

Luby 2004a-i \{published data only\} Luby SP, Agboatwalla M, Hoekstra RM, Rahbar MH, Billhimer W, Keswick BH. Delayed effectiveness of homebased interventions in reducing childhood diarrhea, Karachi, Pakistan. American Journal of Tropical Medicine and Hygiene 2004;71(4):420-7.

Luby 2004a-ii \{published data only\} Luby SP, Agboatwalla M, Hoekstra RM, Rahbar MH, Billhimer W, Keswick BH. Delayed effectiveness of homebased interventions in reducing childhood diarrhea, 
Karachi, Pakistan. American Journal of Tropical Medicine and Hygiene 2004;71(4):420-7.

Luby 2004b-i \{published and unpublished data\}

Luby SP, Agboatwalla M, Painter J, Billhimer W, Keswick

B, Hoekstra RM. Combining drinking water treatment and hand washing for diarrhoea prevention, a cluster randomised controlled trial. Tropical Medicine \& International Health 2006;11(4):479-89.

* Luby SP, Agboatwalla M, Painter J, Keswick B, Billhimer W, Altaf A, et al.Effect of a novel water treatment and handwashing promotion on childhood diarrhea in Pakistan: a randomized controlled trial. Data on file.

Luby 2004b-ii \{unpublished data only\} Luby SP, Agboatwalla M, Painter J, Keswick B, Billhimer W, Altaf A, et al.Effect of a novel water treatment and handwashing promotion on childhood diarrhea in Pakistan: a randomized controlled trial. Data on file.

Luby 2004b-iii \{unpublished data only\} Luby SP, Agboatwalla M, Painter J, Keswick B, Billhimer W, Altaf A, et al.Effect of a novel water treatment and handwashing promotion on childhood diarrhea in Pakistan: a randomized controlled trial. Data on file.

Lule 2005 \{published data only\}

Lule JR, Mermin J, Ekwaru JP, Malamba S, Downing R, Ransom R, et al.Effect of home-based water chlorination and safe storage on diarrhea among persons with human immunodeficiency virus in Uganda. American Journal of Tropical Medicine and Hygiene 2005;73(5):926-33.

Mahfouz 1995 \{published data only\} Mahfouz AA, Abdel-Moneim M, al-Erian RA, al-Amari OM. Impact of chlorination of water in domestic storage tanks on childhood diarrhoea: a commuity trial in the rural areas of Saudi Arabia. American Journal of Tropical Medicine and Hygiene 1995;98(2):126-30.

Messou 1997 \{published data only\}

Messou E, Sangare SV, Josseran R, Le Corre C, Guelain $\mathrm{J}$. Effect of hygiene measures, water, sanitation and oral rehydration therapy on diarrhea in children less than five years old in the south of Ivory Coast [Effet de l'observance des mesures d'hygiene, d'approisionnement en eau et de la therapie par voie orale sur les diarrhees chez les enfants de moins de 5 ans dans le sud de la Cote D'Ivoire]. Bulletin de la Société de Pathologie Exotique (1990) 1997;90(1):44-7.

Quick 1999 \{published and unpublished data\}

* Quick RE, Venczel LV, Mintz ED, Soleto L, Aparicio J, Gironaz M, et al.Diarrhoea prevention in Bolivia through point-of-use water treatment and safe storage: a promising new strategy. Epidemiology and Infection 1999;122(1): 83-90.

Venczel L. Evaluation and application of a mixed oxidant disinfection system for waterborne disease prevention [dissertation]. Chapel Hill (NC): University of North Carolina at Chapel Hill, 1997.

Quick 2002 \{published data only\}

Quick RE, Kimura A, Thevos A, Tembo M, Shamputa I, Hutwagner L, et al.Diarrhea prevention through household- level water disinfection and safe storage in Zambia. American Journal of Tropical Medicine and Hygiene 2002;66 (5):584-9.

\section{Reller 2003-i \{published data only\}}

Reller ME, Mendoza CE, Lopez MB, Alvarez M, Hoekstra AR, Olson CA, et al.A randomized controlled trial of household-based flocculant-disinfectant drinking water treatment for diarrhoea prevention in rural Guatemala. American Journal of Tropical Medicine and Hygiene 2003;69 (4):411-9.

Reller 2003-ii \{published data only\}

Reller ME, Mendoza CE, Lopez MB, Alvarez M, Hoekstra $\mathrm{AR}$, Olson CA, et al.A randomized controlled trial of household-based flocculant-disinfectant drinking water treatment for diarrhoea prevention in rural Guatemala. American Journal of Tropical Medicine and Hygiene 2003;69 (4):411-9.

Reller 2003-iii \{published data only\} Reller ME, Mendoza CE, Lopez MB, Alvarez M, Hoekstra $\mathrm{AR}$, Olson CA, et al.A randomized controlled trial of household-based flocculant-disinfectant drinking water treatment for diarrhoea prevention in rural Guatemala. American Journal of Tropical Medicine and Hygiene 2003;69 (4):411-9.

Reller 2003-iv \{published data only\} Reller ME, Mendoza CE, Lopez MB, Alvarez M, Hoekstra $\mathrm{AR}$, Olson CA, et al.A randomized controlled trial of household-based flocculant-disinfectant drinking water treatment for diarrhoea prevention in rural Guatemala. American Journal of Tropical Medicine and Hygiene 2003;69 (4):411-9.

Roberts 2001 \{published data only\} Roberts L, Chartier Y, Chartier O, Malenga G, Toole M, Rodka H. Keeping clean water clean in a Malawi refugee camp: a randomized intervention trial. Bulletin of the World Health Organization 2001;79(4):280-7.

Semenza 1998 \{published data only\} Semenza JC, Roberts L, Henderson A, Bogan J, Rubin $\mathrm{CH}$. Water distribution system and diarrheal disease transmission: a case study in Uzbekistan. American Journal of Tropical Medicine and Hygiene 1998;59(6):941-6.

Torun 1982 \{published data only\}

Torun B. Environmental and educational interventions against diarrhea in Guatemala. In: Chen LC, Scrimshaw NS editor(s). Diarrhea and malnutrition: interactions, mechanisms and interventions. New York: Plenum Press, 1982:235-66.

URL 1995-i \{published data only\}

Universidad Rafael Landivar. Preventing infant morbidity: artisanal filters and education [Contra la morbilidad infantil: filtros artesanales y education]. Revista de Estudios Sociales 1995;IV(53):1-66.

URL 1995-ii \{published data only\}

Universidad Rafael Landivar. Preventing infant morbidity: artisanal filters and education [Contra la morbilidad infantil: 
filtros artesanales y education]. Revista de Estudios Sociales 1995;IV(53):1-66.

Xiao 1997 \{published data only\}

Xiao S, Lin C, Chen K. Evaluation of effectiveness of comprehensive control for diarrhea diseases in rural areas of east Fujian and analysis of its cost-benefit. Zhonghua $Y u$ Fang Yi Xue Za Zhi [Chinese Journal of Preventive Medicine] 1997;31(1):40-1.

\section{References to studies excluded from this review}

Asaolu 2002 \{published data only\}

Asaolu SO, Ofoezie IE, Odumuyiwa PA, Sowemimo OA, Ogunniyi TA. Effect of water supply and sanitation on the prevalence and intensity of Ascarias lumbricoides among pre-school-age children in Ajebandele and Ifewara, Osun State, Nigeria. Transactions of the Royal Society of Tropical Medicine and Hygiene 2002;96(6):600-4.

Azurin 1974 \{published data only\} Azurin JC, Alvero M. Field evaluation of environmental sanitation measures against cholera. Bulletin of the World Health Organization 1974;51(1):19-26.

Bahl 1976 \{published data only\} Bahl MR. Impact of piped water supply on the incidence of typhoid fever and diarrhoeal diseases in Lusaka. Medical Journal of Zambia 1976;10(4):98-9.

Bersh 1985 \{published data only\} Bersh D, Osorio MM. Studies of diarrhoea in Quindio (Colombia): problems related to water treatment. Social Science \& Medicine 1985;21(1):31-9.

Chongsuvivatwong 94 \{published data only\} Chongsuvivatwong V, Mo-suwan L, Chompikul J, Vitsupakorn K, McNeil D. Effects of piped water supply on the incidence of diarrhoeal diseases in children in southern Thailand. Southeast Asian Journal of Tropical Medicine and Public Health 1994;25(4):628-32.

Colwell 2003 \{published data only\} Colwell RR, Huq A, Islam MS, Aziz K, Yunus M, Khan $\mathrm{NH}$, et al.Reduction of cholera in Bangladeshi villages by simple filtration. Proceedings of the National Academy of Sciences of the United States of America 2003;100(3):1051-5.

Conroy 2001 \{published data only\}

Conroy RM, Meegan ME, Joyce T, McGuigan K, Barnes J. Solar disinfection of drinking water protects against cholera in children under 6 years of age. Archives of Disease in Childhood 2001;85(4):293-5.

Deb 1986 \{published data only\}

Deb BC, Sircar BK, Sengupta PG, De SP, Mondal SK, Gupta DN, et al.Studies on interventions to prevent eltor cholera transmission in urban slums. Bulletin of the World Health Organization 1986;64(1):127-31.

Esrey 1991b \{published data only\}

Esrey SA, Habicht JJP, Latham MC, Sisler DG, Casella G. Drinking water source, diarrhoeal morbidity, and child growth in villages with both traditional and improved water supplies in rural Lesotho, southern Africa. American Journal of Public Health 1988;78(11):1451-5.

Fewtrell 1994 \{published data only\}

Fewtrell L, Kay D, Dunlop J, O'Neill G, Wyer M. Infectious diseases and water-supply disconnections. Lancet 1994;343 (8909): 1370 .

Fewtrell 1997 \{published data only\} Fewtrell L, Kay D, Wyer M, O’Neill G. An investigation into the possible links between shigellosis and hepatitis A and public water supply disconnections. Public Health 1997;111(3):179-81.

Ghannoum 1981 \{published data only\} Ghannoum MA, Moore KE, Al-Dulaimi M, Nasr M. The incidence of water-related diseases in the Brak area, Libya from 1977 to 1979 , before and after the installation of water treatment plants. Zentralblatt für Bakteriologie, Mikrobiologie und Hygiene. 1. Abt. Originale B, Hygiene 1981;173(6):501-8.

Hellard 2001 \{published data only\} Hellard ME, Sinclair MI, Forbes AB, Fairley CK. A randomized, blinded, controlled trial investigating the gastrointestinal health effects of drinking water quality. Environmental Health Perspectives 2001;109(8):773-8.

Hoque 1996 \{published data only\}

Hoque BA, Juncker T, Sack RB, Ali M, Aziz KM. Sustainability of a water, sanitation and hygiene education project in rural Bangladesh: a 5-year follow-up. Bulletin of the World Health Organization 1996;74(4):431-7.

Iijima 2001 \{published data only\} Iijima Y, Karama M, Oundo JO, Honda T. Prevention of bacterial diarrhea by pasteurization of drinking water in Kenya. Microbiology and Immunology 2001;45(6):413-6.

Jensen 2002 \{published data only\}

Jensen PK, Ensink JH, Jayasinghe G, van der Hoek W, Cairncross S, Dalsgaard A. Domestic transmission routes of pathogens: the problem of in-house contamination of drinking water during storage in developing countries. Tropical Medicine \& International Health 2002;7(7):604-9.

Khan 1984 \{published data only\} Khan MU, Khan MR, Hossan B, Ahmed QS. Alum potash in water to prevent cholera. Lancet 1984;2 2(8410): 1032.

Macy 1998 \{published data only\} Macy JT, Quick RE. Evaluation of a novel drinking water treatment and storage intervention in Nicaragua. Revista Panamericana de Salud Pública [Pan American Journal of Public Health] 1998;3(2):135-6.

Maeusezahl 2003 \{unpublished data only\} Maeusezahl D, Tanner M, Hobbins M. The SODIS health impact study. Data on file.

McCabe 1957 \{published data only\} McCabe LJ, Haines TW. Diarrheal disease control by improved human excreta disposal. Public Health Reports 1957;72(10):921-8. 
Mertens 1990 \{published data only\}

Mertens TE, Cousens SN, Fernando MA, Kirkwood BR, Merkle F, Korte R, et al.Health impact evaluation of improved water supplies and hygiene practices in Sri Lanka: background and methodology. Tropical Medicine and Parasitology 1990;41(1):79-88.

Nanan 2003 \{published data only\}

Nanan D, White F, Azam I, Afsar H, Hozhari S. Evaluation of a water, sanitation, and hygiene education intervention on diarrhoea in northern Pakistan. Bulletin of the World Health Organization 2003;81(3):160-5.

Payment 1991a \{published data only\}

Payment P, Franco E, Richardson L, Siemiatycki J. Gastrointestinal health effects associated with the consumption of drinking water produced by point-ofuse domestic reverse-osmosis filtration units. Applied and Environmental Microbiology 1991;57(4):945-8.

Payment 1991b \{published data only\}

Payment P, Richardson L, Siemiatycki J, Dewar R, Edwardes $\mathrm{M}$, Franco E. A randomized trial to evaluate the risk of gastrointestinal disease due to consumption of drinking water meeting current microbiological standards. American Journal of Public Health 1991;81(6):703-8.

Pinfold 1990 \{published data only\}

Pinfold JV. Faecal contamination of water and fingertiprinses as a method for evaluating the effect of low-cost water supply and sanitation activities on faeco-oral disease transmission. II. A hygiene intervention study in rural north-east Thailand. Epidemiology and Infection 1990;105 (2):377-89.

Rubenstein 1969 \{published data only\}

Rubenstein A, Boyle J, Odoroff CL, Kunitz SJ. Effect of improved sanitary facilities on infant diarrhea in a Hopi village. Public Health Reports 1969;84(12):1093-7.

Sathe 1996 \{published data only\}

Sathe AA, Hinge DV, Watve MG. Water treatment and diarrhoea. Lancet 1996;348(9023):335-6.

Shiffman 1978 \{published data only\}

Shiffman MA, Schneider R, Faigenblum JM, Helms R, Turner A. Field studies on water, sanitation and health education in relation to health status in Central America. Progress in Water Technology 1978;11:143-50.

Shum 1971 \{published data only\}

Shum H, Sum CY, Chan-Teo CH. Water-borne dysentery due to Shigella sonnei in Hong Kong. Southeast Asian Journal of Tropical Medicine and Public Health 1971;2(2): $180-5$.

Sorvillo 1994 \{published data only\} Sorvillo FJ, Lieb LE, Nahlen B, Miller J, Mascola L, Ash LR. Municipal drinking water and cryptosporidiosis among persons with AIDS in Los Angeles County. Epidemiology and Infection 1994;113(2):313-20.
Tonglet 1992 \{published data only\}

Tonglet R, Isu K, Mpese M, Dramaix M, Hennart P. Can improvements in water supply reduce childhood diarrhoea? Health Policy and Planning 1992;7(3):260-8.

Trivedi 1971 \{published data only\}

Trivedi BK, Gandhi HS, Shukla NK. Bacteriological water quality and incidence of water borne diseases in a rural population. Indian Journal of Medical Sciences 1971;25(11): 795-801.

VanDerslice 1995 \{published data only\}

VanDerslice J, Briscoe J. Environmental interventions in developing countries: interactions and their implications. American Journal of Epidemiology 1995;141(2):135-44.

Varghese 2002 \{unpublished data only\}

Varghese A. Point-of-use water treatment systems in rural Haiti: human health and water quality impact assessment [dissertation]. Cambridge (MA): Massachusetts Institute of Technology, 2002.

\section{References to studies awaiting assessment}

\section{Clasen 2005 \{published data only\}}

Clasen T, Garcia Parra G, Boisson S, Collin S. Householdbased ceramic water filters for the prevention of diarrhea: a randomized, controlled trial of a pilot program in Colombia. American Journal of Tropical Medicine and Hygiene 2005;73 (4):790-5.

\section{Colford 2005a \{published data only\}}

Colford JM, Wade TJ, Sandhu SK, Wright CC, Lee S, Shaw $S$, et al.A randomized, controlled trial of in-home drinking water interventions to reduce gastrointestinal illness. American Journal of Epidemiology 2005;161(5):472-82.

Colford 2005b \{published data only\} Colford JM, Saha SR, Wade TJ, Wright CC, Vu M, Charles $S$, et al.A pilot randomized, controlled trial of an in-home drinking water intervention among HIV + persons. Journal of Water and Health 2005;3(2):173-84.

Rose 2006 \{published data only\} Rose A, Roy S, Abraham V, Homgren G, George K, Balraj $\mathrm{V}$, et al.Solar disinfection of water for diarrhoeal prevention in Southern. Archives of Disease in Childhood 2006;91(2): $139-41$.

\section{Additional references}

\section{Baqui 1993}

Baqui AH, Black RE, Sack RB, Chowdhury HR, Yunus M, Siddique AK. Malnutrition, cell-mediated immune deficiency, and diarrhea: a community-based longitudinal study in rural Bangladeshi children. American Journal of Epidemiology 1993;137(3):355-65.

Bartram 2003

Bartram J. New water forum will repeat old message. Bulletin of the World Health Organization 2003;83(3):158. 
Black 1993

Black RE. Persistent diarrhea in children of developing countries. Pediatric Infectious Disease Journal 1993;12(9): 751-61.

Blaser 1995

Blaser MJ, Smith PD, Ravdin JI, Greenberg HB, Guerrant RL. Infections of the gastrointestinal tract. New York: Raven Press, 1995.

Blum 1983

Blum D, Feachem RG. Measuring the impact of water supply and sanitation investments on diarrhoeal diseases: problems in methodology. International Journal of Epidemiology 1983;12(3):357-65.

Briscoe 1984

Briscoe J. Intervention studies and the definition of dominant transmission routes. American Journal of Epidemiology 1984;120(3):449-55.

\section{Briscoe 1986}

Briscoe J, Feachem RG, Rahaman MM. Evaluating health impact: Water supply, sanitation, and hygiene education. Ottawa: International Development Research Centre, 1986.

\section{Byers 2001}

Byers KE, Guerrant RL, Farr BM. Fecal-oral transmission. In: Thomas JC, Webber DJ editor(s). Epidemiologic methods for the study of infectious diseases. Oxford: Oxford University Press, 2001:228-48.

Cairncross 1989

Cairncross S. Water supply and sanitation: an agenda for research. Journal of Tropical Medicine and Hygiene 1989;92 (5):301-14.

\section{Clasen 2004a}

Clasen TF, Cairncross S. Household water treatment: refining the dominant paradigm. Tropical Medicine and International Health 2004;9(2):187-91.

\section{Clesceri 1998}

Clesceri LS, Greenberg AE, Eaton AD, editors. Standard methods for the examination of water and wastewater. 20th Edition. Washington, DC: American Public Health Association and American Water Works Association, 1998.

\section{Curtis 2003}

Curtis V, Cairncross S. Effect of washing hands with soap on diarrhoea risk in the community: a systematic review. Lancet Infectious Diseases 2003;3(5):275-81.

\section{Egger 2001}

Egger M, Davey Smith G. Principles of and procedures for systematic reviews. In: Egger M, Davey Smith G, Altman DG editor(s). Systematic reviews in health care: Meta-analysis in context. 2nd Edition. London: BMJ Books, 2001:23-42.

\section{Esrey 1985}

Esrey SA, Feachem RG, Hughes JM. Interventions for control of diarrhoeal diseases among young children: improving water supplies and excreta disposal facilities. Bulletin of the World Health Organization 1985;63(4): 757-72.

\section{Esrey 1986}

Esrey SA, Habicht JP. Epidemiologic evidence for health benefits from improved water and sanitation in developing countries. Epidemiologic Reviews 1986;8:117-28.

\section{Esrey 1991a}

Esrey SA, Potash JB, Roberts L, Shiff C. Effects of improved water supply and sanitation on ascariasis, diarrhoea, dracunculiasis, hookworm infection, schistosomiasis, and tracoma. Bulletin of the World Health Organization 1991;69 (5):609-21.

\section{Feachem 1983}

Feachem RG, Hogan RC, Merson MH. Diarrhoeal disease control: reviews of potential interventions. Bulletin of the World Health Organization 1983;61(4):637-40.

\section{Fewtrell 2005}

Fewtrell L, Kaufmann RB, Kay D, Enanoria W, Haller L, Colford JM. Water, sanitation, and hygiene interventions to reduce diarrhoea in less developed countries: a systematic review and meta-analysis. Lancet Infectious Diseases 2005;5 (1):42-52.

\section{Gleeson 1997}

Gleeson C, Gray N. The coliform index and waterborne disease: problems of microbial drinking water assessment. London: Spon Press, 1997.

\section{Guerrant 1999}

Guerrant DI, Moore SR, Lima AA, Patrick PD, Schorling JB, Guerrant RL. Association of early childhood diarrhea and cryptosporidiosis with impaired physical fitness and cognitive function four-seven years later in a poor urban community in northeast Brazil. American Journal of Tropical Medicine and Hygiene 1999;61(5):707-13.

\section{Hayes 2003}

Hayes C, Elliot E, Krales E, Downer G. Food and water safety for persons infected with human immunodeficiency virus. Clinical Infectious Diseases 2003;36 Suppl 2:106-9.

\section{Higgins 2003}

Higgins JPT, Thompson SG, Deeks JJ, Altman DG. Measuring inconsistency in meta-analysis. BMJ 2003;327 (7414):557-60.

\section{Higgins 2005a}

Higgins JPT, Green S, editors. Analysing and presenting results. Cochrane Handbook for Systematic Reviews of Interventions 4.2.5 [updated May 2005]; Section 8. www.cochrane.org/resources/handbook/hbook.htm (accessed 1 January 2006).

\section{Higgins 2005b}

Higgins J, Green S, editors. Highly sensitive search strategies for identifying reports of randomized controlled trials in MEDLINE. Cochrane Handbook for Systematic Reviews of Interventions 4.2.5 [updated May 2005]; Appendix 5b. www.cochrane.org/resources/handbook/ hbook.htm (accessed 1 January 2006).

\section{Hunter 1997}

Hunter PR. Waterborne disease epidemiology and ecology. Chichester: John Wiley \& Sons, 1997. 


\section{Hutton 2004}

Hutton G, Haller L. Evaluation of the costs and benefits of water and sanitation improvements at the global level. Geneva: World Health Organization, 2004.

\section{Imo State Team 1989}

Imo State Evaluation Team. Evaluating water and sanitation projects: lessons from Imo State, Nigeria. Health Policy and Planning 1989;4(1):40-9.

\section{Kosek 2003}

Kosek M, Bern C, Guerrant RL. The global burden of diarrhoeal disease, as estimated from studies published between 1992 and 2000. Bulletin of the World Health Organization 2003;81(3):197-204.

\section{Last 2001}

Last JM. A dictionary of epidemiology. 4th Edition. Oxford: Oxford University Press, 2001.

\section{Leclerc 2002}

Leclerc H, Schwartzbrod L, Dei-Cas E. Microbial agents associated with waterborne diseases. Critical Reviews in Microbiology 2002;28(4):371-409.

\section{Lindskog 1987}

Lindskog U, Lindskog P, Wall S. Water supply, sanitation and health education programmes in developing countries: problems of evaluation. Scandinavian Journal of Social Medicine 1987;15(3):123-30.

Luby 2004

Luby S. Health outcome evaluation of point of use water treatment. Proceedings of the IWA 4th World Water Congress; 19 to 24 September 2004; Marrakech, Morocco. 2004.

\section{McNutt 2003}

McNutt LA, Wu C, Xue X, Hafner JP. Estimating the relative risk in cohort studies and clinical trials of common outcomes. American Journal of Epidemiology 2003;157(10): $940-3$.

\section{Mintz 2001}

Mintz E, Bartram J, Lochery P, Wegelin M. Not just a drop in the bucket: expanding access to point-of-use water treatment systems. American Journal of Public Health 2001; 91(10):1565-70.

\section{Morris 1996}

Morris SS, Cousens SN, Kirkwood BR, Arthur P, Ross DA. Is prevalence of diarrhoea a better predictor of subsequent mortality and weight gain than diarrhea incidence?. American Journal of Epidemiology 1996;144(6):582-8.

\section{Review Manager 4.2}

The Nordic Cochrane Centre, The Cochrane Collaboration. Review Manager (RevMan). 4.2 for Windows. Copenhagen: The Nordic Cochrane Centre, The Cochrane Collaboration, 2002.

\section{Schneider 1978}

Schneider RE, Shiffman M, Faigenblum J. The potential effect of water on gastrointestinal infections prevalent in developing countries. American Journal of Clinical Nutrition 1978;31(11):2089-99.

Sobsey 2002

Sobsey MD. Managing water in the home: accelerated health gains from improved water supply [WHO/SDE/WSH/02.07]. Geneva: World Health Organization, 2002.

\section{Sphere Project 2004}

The Sphere Project. Humanitarian charter and minimum standards in disaster response. Oxford: Oxfam Publishing, 2004.

United Nations 2005

United Nations Statistics Division. Progress towards the Millennium Development Goals, 1990-2005: Goal 4. Reduce child mortality. unstats/un.org/unsd/mi/ goals 2005/goal 4.pdf (accessed 15 November 2005).

\section{Venczel 1997}

Venczel LA, Arrowood M, Hurd M, Sobsey MD. Inactivation of Cryptosporidium parvum oocysts and Clostridium perfringes spores by a mixed-oxidant disinfectant and by free chlorine. Applied and Environmental Microbiology 1997;63(4):1598-601.

\section{WHO 1993}

World Health Organization. The management and prevention of diarrhoea: practical guidelines. 3rd Edition. Geneva: World Health Organization, 1993.

\section{WHO 2002}

World Health Organization. The World health report: 2002 $:$ Reducing the risks, promoting healthy life [WHO/WHR]

02.1]. Geneva: World Health Organization, 2002.

\section{WHO 2004}

World Health Organization. Guidelines for drinking-water quality. Vol. 1, Recommendations. 3rd Edition. Vol. 1, Geneva: World Health Organization, 2004.

\section{WHO 2005}

World Health Organization. The World health report: 2005 : make every mother and child count. Geneva: World Health Organization, 2005.

\section{WHO/UNICEF 2000}

WHO/UNICEF Joint Monitoring Programme for Water Supply and Sanitation. Global water supply and sanitation assessment 2000 report. Geneva: World Health Organization, 2000.

\section{Wright 2004}

Wright J, Gundry S, Conroy R. Household drinking water in developing countries: a systematic review of microbiological contamination between source and pointof-use. Tropical Medicine and International Health 2004;9 (1):106-17.

Zhang 1998

Zhang J, Yu KF. What's the relative risk? A method of correcting the odds ratio in cohort studies of common outcomes. JAMA 1998;280(19):1690-1.

* Indicates the major publication for the study 


\section{CHARACTERISTICS OF STUDIES}

\section{Characteristics of included studies [ordered by study ID]}

\begin{tabular}{ll} 
Alam 1989 & \\
\hline Methods & Quasi-randomized controlled trial \\
\hline Participants & $\begin{array}{l}\text { Number: } 623 \text { children } \\
\text { Inclusion criteria: aged } 6 \text { to } 23 \text { months }\end{array}$ \\
\hline Interventions & $\begin{array}{l}\text { 1. Improved water supply }+ \text { hygiene education }(3 \text { subunits }) \\
\text { 2. Primary drinking supply }(2 \text { subunits })\end{array}$ \\
\hline Outcomes & $\begin{array}{l}\text { 1. Incidence of diarrhoea among children aged } 6 \text { to } 23 \text { months by water source, hygiene practices, and household } \\
\text { socioeconomic characteristics }\end{array}$ \\
\hline Notes & $\begin{array}{l}\text { Location: } 5 \text { political subunits in a village in rural Bangladesh } \\
\text { Length: } 3 \text { years } \\
\text { Publication status: journal }\end{array}$ \\
\hline
\end{tabular}

Austin 1993-i

\begin{tabular}{ll}
\hline Methods & Randomized controlled trial \\
\hline Participants & $\begin{array}{l}\text { Number: } 287 \text { children } \\
\text { Inclusion criteria: aged } 25 \text { to } 60 \text { months (group B) from villages primarily using open, shallow wells for drinking } \\
\text { water }\end{array}$ \\
\hline Interventions & $\begin{array}{l}\text { 1. Sodium hypochlorite solution used at household level (11 villages) } \\
\text { 2. Primary drinking supply (11 villages) }\end{array}$ \\
\hline Outcomes & $\begin{array}{l}\text { 1. Longitudinal prevalence of diarrhoea } \\
\text { 2. Change in nutritional status using weight-for-height Z-score }\end{array}$ \\
\hline Notes & $\begin{array}{l}\text { Location: } 22 \text { rural villages in The Gambia } \\
\text { Length: } 20 \text { weeks } \\
\text { Publication status: PhD dissertation }\end{array}$ \\
\hline
\end{tabular}

Austin 1993-ii

\begin{tabular}{l|l}
\hline Methods & As above \\
\hline Participants & Number: 144 children between 6 and 24 months \\
\hline Interventions & As above \\
\hline Outcomes & As above
\end{tabular}




\section{Austin 1993-ii (Continued)}

\begin{tabular}{l|l}
\hline Notes & As above \\
\hline Aziz 1990 & Quasi-randomized controlled trial \\
\hline Methods & \begin{tabular}{l} 
Number: about 9600 people of all ages from 1570 households \\
\hline Participants
\end{tabular} \\
\hline Interventions & $\begin{array}{l}\text { 1. Improved water supply }+ \text { sanitation }+ \text { hygiene education } \\
\text { 2. Primary drinking supply }\end{array}$ \\
\hline Outcomes & $\begin{array}{l}\text { 1. Longitudinal prevalence of diarrhoea: } \\
\text { - portion of among children }<5 \text { years } \\
\text { - odds ratios of frequent diarrhoea } \\
\text { - related to environmental factors }\end{array}$ \\
\hline Notes & $\begin{array}{l}\text { Location: } 2 \text { villages in rural Bangladesh } \\
\text { Length: } 3 \text { years } \\
\text { Publication status: journal }\end{array}$ \\
\hline
\end{tabular}

\section{Chiller 2004}

Methods Randomized controlled trial

\begin{tabular}{ll}
\hline Participants & $\begin{array}{l}\text { Number: } 3401 \text { persons } \\
\text { Inclusion criteria: all ages from } 514 \text { households with at least one child under } 1 \text { year }\end{array}$ \\
\hline Interventions & $\begin{array}{l}\text { 1. Flocculant-disinfectant sachets used at household level + hygiene education } \\
\text { 2. Primary drinking supply }\end{array}$ \\
\hline Outcomes & $\begin{array}{l}\text { 1. Longitudinal prevalence of diarrhoea (portion of total days of diarrhoea out of total days of observation) among } \\
\text { all ages } \\
\text { 2. Incidence of persistent diarrhoea }\end{array}$ \\
\hline Notes & $\begin{array}{l}\text { Location: } 42 \text { neighbourhood clusters in } 12 \text { rural villages in Guatemala } \\
\text { Length: } 13 \text { weeks } \\
\text { Publication status: unpublished }\end{array}$ \\
\hline
\end{tabular}


Clasen 2004b

\begin{tabular}{|c|c|}
\hline Methods & Randomized controlled trial \\
\hline Participants & 324 persons of all ages from 60 households \\
\hline Interventions & $\begin{array}{l}\text { 1. Household gravity water filter system using imported ceramic filter elements } \\
\text { 2. Primary drinking supply }\end{array}$ \\
\hline Outcomes & $\begin{array}{l}\text { 1. Period prevalence of diarrhoea ( } 7 \text {-day recall) among all ages } \\
\text { 2. Microbial water quality }\end{array}$ \\
\hline Notes & $\begin{array}{l}\text { Location: rural Bolivian community } \\
\text { Length: } 5 \text { months } \\
\text { Publication status: unpublished }\end{array}$ \\
\hline \multicolumn{2}{|l|}{ Clasen 2004c } \\
\hline Methods & Randomized controlled trial \\
\hline Participants & Number: 50 households with 280 persons, of which $32(11 \%)$ were under age 5 \\
\hline Interventions & $\begin{array}{l}\text { 1. Household gravity water filter system using imported ceramic filter elements } \\
\text { 2. Primary drinking supply }\end{array}$ \\
\hline Outcomes & 1. Period prevalence of diarrhoea (7-day recall) among householders assessed at approximately 6 -week intervals \\
\hline Notes & $\begin{array}{l}\text { Location: rural Bolivia } \\
\text { Length: } 6 \text { months } \\
\text { Publication status: journal }\end{array}$ \\
\hline
\end{tabular}

Colford 2002

\begin{tabular}{ll}
\hline Methods & Randomized controlled trial \\
\hline Participants & 236 children 12 years or older from 77 households \\
\hline Interventions & $\begin{array}{l}\text { 1. Household reverse osmosis filters } \\
\text { 2. Primary drinking supply }\end{array}$ \\
\hline Outcomes & $\begin{array}{l}\text { 1. Incidence of watery diarrhoea } \\
\text { 2. Gastrointestinal illness and various other symptoms }\end{array}$ \\
\hline $\begin{array}{l}\text { 3. Water consumption } \\
\text { 4. Effectiveness of blinding }\end{array}$ \\
\hline Notes & $\begin{array}{l}\text { Location: urban community in California, USA } \\
\text { Length: } 4 \text { months }\end{array}$ \\
\hline
\end{tabular}


Conroy 1996

\begin{tabular}{|c|c|}
\hline Methods & Randomized controlled trial \\
\hline Participants & 206 Maasai children aged 5 to 16 years in 3 adjoining areas of single province \\
\hline Interventions & $\begin{array}{l}\text { 1. Solar disinfection in plastic bottles at household level } \\
\text { 2. Primary drinking supply }\end{array}$ \\
\hline Outcomes & 1. Period prevalence of diarrhoea \\
\hline Notes & $\begin{array}{l}\text { Location: single province of rural Kenya } \\
\text { Length: } 12 \text { weeks } \\
\text { Publication status: journal }\end{array}$ \\
\hline
\end{tabular}

Conroy 1999

\begin{tabular}{|c|c|}
\hline Methods & Randomized controlled trial \\
\hline Participants & 349 Maasai children $<6$ years in 140 households \\
\hline Interventions & $\begin{array}{l}\text { 1. Solar disinfection in plastic bottles at household level } \\
\text { 2. Primary drinking supply }\end{array}$ \\
\hline Outcomes & 1. Period prevalence of diarrhoea \\
\hline Notes & $\begin{array}{l}\text { Location: rural Kenya } \\
\text { Length: } 1 \text { year } \\
\text { Publication status: journal }\end{array}$ \\
\hline
\end{tabular}

Crump 2004-i

\begin{tabular}{ll}
\hline Methods & Randomized controlled trial \\
\hline Participants & $\begin{array}{l}6650 \text { persons of all ages in } 604 \text { family compounds; participation limited to family compounds with at least } 1 \text { child } \\
<2 \text { years and likely to be using highly turbid source water }\end{array}$ \\
\hline Interventions & $\begin{array}{l}\text { 1. Sodium hypochlorite used at household level + hygiene education } \\
\text { 2. Primary drinking supply }\end{array}$ \\
\hline Outcomes & $\begin{array}{l}\text { 1. Longitudinal prevalence (weeks with diarrhoea/weeks of observation) among all ages } \\
\text { 2. Breastfeeding and consumption of food and water for children }<2 \text { years } \\
\text { 3. Deaths } \\
\text { 4. Use of intervention } \\
\text { 5. Mothers' knowledge of and acceptance of intervention (weeks } 5 \text { and 15) } \\
\text { 6. Microbial water quality and turbidity } \\
\text { 7. Mothers' knowledge of and attitudes to intervention }\end{array}$
\end{tabular}




\section{Crump 2004-i (Continued)}

Notes Location: 49 rural villages in western Kenya

Length: 20 weeks

Publication status: unpublished

Crump 2004-ii

\begin{tabular}{ll}
\hline Methods & See Crump 2004-i \\
\hline Participants & As above \\
\hline Interventions & $\begin{array}{l}\text { 1. Flocculant-disinfectant sachets used at household level + hygiene } \\
\text { 2. Primary drinking supply }\end{array}$ \\
\hline Outcomes & As above \\
\hline Notes & As above \\
\hline
\end{tabular}

Doocy 2004

\begin{tabular}{ll}
\hline Methods & Randomized controlled trial \\
\hline Participants & $\begin{array}{l}\text { 2191 persons of all ages (1138 intervention, } 1053 \text { controls), of which } 735 \text { are children }<5(395 \text { intervention, } 340 \\
\text { controls) from households in settlement area not using treated water for drinking }\end{array}$ \\
\hline Interventions & $\begin{array}{l}\text { 1. Flocculant-disinfectant sachets used at household level, plus water storage vessel } \\
\text { 2. Primary drinking supply; also received vessel }\end{array}$ \\
\hline Outcomes & $\begin{array}{l}\text { 1. Longitudinal prevalence (days with diarrhoea/total days of observation) } \\
\text { 2. Prevalence of bloody diarrhoea } \\
\text { 3. Utilization and acceptability data from exit survey }\end{array}$ \\
\hline Notes & $\begin{array}{l}\text { Location: Liberian camp for displaced persons } \\
\text { Length: } 12 \text { weeks } \\
\text { Publication status: unpublished }\end{array}$ \\
\hline
\end{tabular}

\section{du Preez 2004}

\begin{tabular}{ll} 
Methods & Randomized controlled trial \\
\hline Participants & 115 children $<5$ years \\
\hline Interventions & $\begin{array}{l}\text { 1. Household commercial ceramic filter using imported components }(60 \text { children }) \\
\text { 2. Primary drinking supply }(55 \text { children })\end{array}$
\end{tabular}


du Preez 2004 (Continued)

\begin{tabular}{ll}
\hline Outcomes & $\begin{array}{l}\text { 1. Incidence of diarrhoea } \\
\text { 2. Incidence of bloody diarrhoea and non-bloody diarrhoea } \\
\text { 3. Microbiological water quality }\end{array}$ \\
\hline Notes & $\begin{array}{l}\text { Location: rural South Africa and Zimbabwe } \\
\text { Length: } 6 \text { months } \\
\text { Publication status: unpublished }\end{array}$ \\
\hline
\end{tabular}

\section{Garrett 2004}

\begin{tabular}{|c|c|}
\hline Methods & Quasi-randomized controlled trial \\
\hline Participants & 960 children $<5$ years \\
\hline Interventions & $\begin{array}{l}\text { 1. Household chlorination using sodium hypochlorite solution }+ \text { improved water supply }+ \text { sanitation }+ \text { hygiene } \\
\text { education }+ \text { improved storage }(618 \text { children }) \\
\text { 2. Primary drinking supply }(342 \text { children })\end{array}$ \\
\hline Outcomes & 1. Incidence of diarrhoea \\
\hline Notes & $\begin{array}{l}\text { Location: rural Kenya } \\
\text { Length: not reported } \\
\text { Publication status: unpublished }\end{array}$ \\
\hline
\end{tabular}

Gasana 2002

\begin{tabular}{|c|c|}
\hline Methods & Quasi-randomized controlled trial \\
\hline Participants & 150 children $<5$ years (in intervention group, controls) \\
\hline Interventions & $\begin{array}{l}\text { 1. Improved source: pipes to stand post; sedimentation tank; ceramic filter; storage tank; and communal tap (95 } \\
\text { children) } \\
\text { 2. Primary drinking supply ( } 55 \text { children) }\end{array}$ \\
\hline Outcomes & 1. Incidence of diarrhoea \\
\hline Notes & $\begin{array}{l}\text { Location: rural Rwanda } \\
\text { Length: } 1 \text { year } \\
\text { Publication status: journal }\end{array}$ \\
\hline
\end{tabular}


Handzel 1998

\begin{tabular}{ll}
\hline Methods & Randomized controlled trial \\
\hline Participants & $\begin{array}{l}447 \text { children aged } 3 \text { to } 60 \text { months from } 276 \text { households using municipal water (household taps) as primary source } \\
\text { of drinking water which had tested positive at baseline for Escherichia coli }\end{array}$ \\
\hline Interventions & $\begin{array}{l}\text { 1. Household chlorination using sodium hypochlorite solution, special storage vessel and hygiene instruction about } \\
\text { why and how to treat water (140 households) }\end{array}$ \\
\hline 2. Primary drinking supply (136 households)
\end{tabular}

Jensen 2003

\begin{tabular}{ll}
\hline Methods & Quasi-randomized controlled trial \\
\hline Participants & 226 children $<5$ years \\
\hline Interventions & $\begin{array}{l}\text { 1. Village level chlorination of water supply using calcium hypochlorite (82 children) } \\
\text { 2. Primary drinking supply (144 children) }\end{array}$ \\
\hline Outcomes & $\begin{array}{l}\text { 1. Incidence of diarrhoea } \\
\text { 2. Microbial water quality }\end{array}$ \\
\hline Notes & $\begin{array}{l}\text { Location: } 2 \text { villages in Pakistan } \\
\text { Length: } 6 \text { months } \\
\text { Publication status: journal } \\
\text { Controlled for sanitation and water storage status of households, and for seasonality }\end{array}$ \\
\hline
\end{tabular}

\section{Kirchhoff 1985}

\begin{tabular}{l|l}
\hline Methods & Randomized controlled trial \\
\hline Participants & 112 persons (all ages) from 20 families with at least 2 children living at home and using water from pond exclusively \\
\hline Interventions & $\begin{array}{l}\text { 1. Household level chlorination with sodium hypochlorite } \\
\text { 2. Primary drinking supply }\end{array}$ \\
\hline Outcomes & $\begin{array}{l}\text { 1. Longitudinal prevalence of diarrhoea } \\
\text { 2. Microbial water quality } \\
\text { 3. Acceptability of intervention to study population }\end{array}$
\end{tabular}




\section{Kirchhoff 1985 (Continued)}

\begin{tabular}{ll}
\hline Notes & Location: rural Brazil \\
& Length: 18 weeks \\
& Publication status: journal \\
\hline
\end{tabular}

Luby 2004a-i

\begin{tabular}{|c|c|}
\hline Methods & Quasi-randomized controlled trial \\
\hline Participants & 2365 persons $<15$ years from 285 households \\
\hline Interventions & $\begin{array}{l}\text { 1. Bleach }+ \text { regular vessel }(640 \text { people }) \\
\text { 2. Primary drinking supply ( } 1027 \text { people })\end{array}$ \\
\hline Outcomes & $\begin{array}{l}\text { 1. Longitudinal prevalence of diarrhoea } \\
\text { 2. Use of intervention by certain household characteristics }\end{array}$ \\
\hline Notes & $\begin{array}{l}\text { Location: } 3 \text { neighbourhoods in squatter settlements in Karachi, Pakistan } \\
\text { Length: } 6 \text { months } \\
\text { Publication status: journal }\end{array}$ \\
\hline
\end{tabular}

Luby 2004a-ii

\begin{tabular}{ll}
\hline Methods & See Luby 2004a-i \\
\hline Participants & See Luby 2004a-i \\
\hline Interventions & $\begin{array}{l}\text { 1. Bleach }+ \text { insulated vessel (697 people) } \\
\text { 2. Primary drinking supply (1027 people })\end{array}$ \\
\hline Outcomes & See Luby 2004a-i \\
\hline Notes & See Luby 2004a-i \\
\hline
\end{tabular}

\section{Luby 2004b-i}

\begin{tabular}{ll}
\hline Methods & Randomized controlled trial \\
\hline Participants & 5520 persons of all ages \\
\hline Interventions & $\begin{array}{l}\text { 1. Dilute bleach + vessel (1747 people) } \\
\text { 2. Primary drinking supply (1852 people) }\end{array}$ \\
\hline Outcomes & 1. Incidence and longitudinal prevalence of diarrhoea
\end{tabular}




\section{Luby 2004b-i (Continued)}

$\begin{array}{ll}\text { Notes } & \text { Location: } 47 \text { squatter settlements of Karachi, Pakistan } \\ & \text { Length: } 8 \text { months } \\ & \text { Publication status: unpublished }\end{array}$

Luby 2004b-ii

\begin{tabular}{ll}
\hline Methods & See Luby $2004 \mathrm{~b}-\mathrm{i}$ \\
\hline Participants & See Luby $2004 \mathrm{~b}-\mathrm{i}$ \\
\hline $\begin{array}{l}\text { Interventions } \\
\text { 1. Flocculant-disinfectant + soap (1806 in flocculant-disinfection group) } \\
\text { 2. Primary drinking supply (1852 people) }\end{array}$ \\
\hline Outcomes & See Luby 2004b-i \\
\hline Notes & See Luby 2004b-i \\
\hline
\end{tabular}

\section{Luby 2004b-iii}

\begin{tabular}{ll}
\hline Methods & See Luby $2004 \mathrm{~b}-\mathrm{i}$ \\
\hline Participants & See Luby $2004 \mathrm{~b}-\mathrm{i}$ \\
\hline Interventions & $\begin{array}{l}\text { 1. Flocculant-disinfectant }+ \text { vessel }(1833 \text { in flocculant-disinfection group }) \\
\text { 2. Primary drinking supply (1852 people, } 40.0 \%)\end{array}$ \\
\hline Outcomes & See Luby $2004 \mathrm{~b}-\mathrm{i}$ \\
\hline Notes & See Luby $2004 \mathrm{~b}-\mathrm{i}$ \\
\hline
\end{tabular}

Lule 2005

\begin{tabular}{ll}
\hline Methods & Randomized controlled trial \\
\hline Participants & $\begin{array}{l}\text { 2201 persons of all ages among } 458 \text { households without access to chlorinated municipal water; at least } 1 \text { resident of } \\
\text { each household was HIV+ }\end{array}$ \\
\hline Interventions & $\begin{array}{l}\text { 1. Household level chlorination using sodium hypochlorite + special vessel (1097 people) } \\
\text { 2. Primary drinking supply (1104 people) }\end{array}$ \\
\hline $\begin{array}{l}\text { Note: hygiene education was provided to both groups } \\
\text { Outcomes }\end{array}$ & $\begin{array}{l}\text { 1. Incidence of diarrhoea } \\
\text { 2. Days with diarrhoea (longitudinal prevalence) } \\
\text { 3. Days lost from work or school } \\
\text { 4. Aetiology of diarrhoea } \\
\text { 5. Frequency of clinic visits and hospitalization }\end{array}$
\end{tabular}


Lule 2005 (Continued)

6. Mortality

Location: households in rural Uganda
Length: 5 months
Publication status: unpublished
Succeeded by 18 -month Randomized controlled trial that included cotrimoxazole prophylaxis

\section{Mahfouz 1995}

\begin{tabular}{|c|c|}
\hline Methods & Quasi-randomized controlled trial \\
\hline Participants & 311 children $<5$ years (among intervention households, among controls) among 171 families \\
\hline Interventions & $\begin{array}{l}\text { 1. Household level chlorination using calcium hypochlorite ( } 159 \text { children) } \\
\text { 2. Primary drinking supply ( } 152 \text { children) }\end{array}$ \\
\hline Outcomes & 1. Reported cases of diarrhoea in intervention year compared with previous year \\
\hline Notes & $\begin{array}{l}\text { Location: } 9 \text { villages in rural Saudi Arabia } \\
\text { Length: } 6 \text { months } \\
\text { Publication status: journal }\end{array}$ \\
\hline
\end{tabular}

\section{Messou 1997}

\begin{tabular}{ll}
\hline Methods & Quasi-randomized controlled trial \\
\hline Participants & Approximately 985 to 1260 (depending on study year) children $<5$ years \\
\hline Interventions & $\begin{array}{l}\text { 1. Improved water supply }+ \text { sanitation }+ \text { hygiene education }+ \text { oral rehydration therapy for those suffering from } \\
\text { diarrhoea (2 villages) } \\
\text { 2. Primary drinking supply (2 villages) }\end{array}$ \\
\hline Outcomes & $\begin{array}{l}\text { 1. Incidence of diarrhoea } \\
\text { 2. Reduction in deaths attributable to diarrhoea } \\
\text { 3. Utilization of oral rehydration solution }\end{array}$ \\
\hline Notes & $\begin{array}{l}\text { Location: } 4 \text { villages in rural Ivory Coast } \\
\text { Length: } 5 \text { years } \\
\text { Publication status: journal }\end{array}$ \\
\hline
\end{tabular}


Quick 1999

\begin{tabular}{ll}
\hline Methods & Randomized controlled trial \\
\hline Participants & 791 persons of all ages from 127 households \\
\hline Interventions & $\begin{array}{l}\text { 1. Household level chlorination + vessel + hygiene education ( } 400 \text { people, } 64 \text { households) } \\
\text { 2. Primary drinking supply }(391 \text { people, } 63 \text { households) }\end{array}$ \\
\hline Outcomes & $\begin{array}{l}\text { 1. Mean episodes of diarrhoea per person } \\
\text { 2. Microbiological water quality }\end{array}$ \\
\hline Notes & $\begin{array}{l}\text { Location: } 2 \text { peri-urban communities in Bolivia } \\
\text { Length: } 5 \text { months } \\
\text { Publication status: journal }\end{array}$ \\
\hline
\end{tabular}

Quick 2002

\begin{tabular}{ll}
\hline Methods & Quasi-randomized controlled trial \\
\hline Participants & 1584 persons of all ages from 260 households \\
\hline Interventions & $\begin{array}{l}\text { 1. Household level chlorination + vessel + hygiene education (166 households) } \\
\text { 2. Primary drinking supply (94 households) }\end{array}$ \\
\hline Outcomes & $\begin{array}{l}\text { 1. Incidence of diarrhoea } \\
\text { 2. Microbiological water quality }\end{array}$ \\
\hline Notes & $\begin{array}{l}\text { Location: } 2 \text { peri-urban communities in Zambia } \\
\text { Length: } 3 \text { months } \\
\text { Publication status: journal }\end{array}$ \\
\hline
\end{tabular}

Reller 2003-i

\begin{tabular}{ll}
\hline Methods & Randomized controlled trial \\
\hline Participants & \begin{tabular}{l}
492 households each with a child $<12$ months or mother in last trimester of pregnancy \\
\hline Interventions
\end{tabular} \\
\hline $\begin{array}{l}\text { 1. Flocculant-disinfectant }(102 \text { households }) \\
\text { 2. Primary drinking supply }(96 \text { households })\end{array}$ \\
\hline Outcomes & $\begin{array}{l}\text { 1. Incidence of diarrhoea } \\
\text { 2. Intervention knowledge and acceptability } \\
\text { 3. Microbiological water quality } \\
\text { 4. Intervention utilization }\end{array}$ \\
\hline Notes & $\begin{array}{l}\text { Location: } 12 \text { villages in rural Guatemala } \\
\text { Length: } 12 \text { months } \\
\text { Publication status: journal }\end{array}$ \\
\hline
\end{tabular}


Reller 2003-ii

\begin{tabular}{|c|c|}
\hline Methods & See Reller 2003-i \\
\hline Participants & See Reller 2003-i \\
\hline Interventions & $\begin{array}{l}\text { 1. Bleach only ( } 97 \text { households) } \\
\text { 2. Primary drinking supply (as above) }\end{array}$ \\
\hline Outcomes & See Reller 2003-i \\
\hline Notes & See Reller 2003-i \\
\hline \multicolumn{2}{|l|}{ Reller 2003-iii } \\
\hline Methods & See Reller 2003-i \\
\hline Participants & See Reller 2003-i \\
\hline Interventions & $\begin{array}{l}\text { 1. Bleach }+ \text { vessel ( } 97 \text { households) } \\
\text { 2. Primary drinking supply (as above) }\end{array}$ \\
\hline Outcomes & See Reller 2003-i \\
\hline Notes & See Reller 2003-i \\
\hline
\end{tabular}

Reller 2003-iv

\begin{tabular}{ll}
\hline Methods & See Reller 2003-i \\
\hline Participants & See Reller 2003-i \\
\hline Interventions & $\begin{array}{l}\text { 1. Flocculant-disinfectant + vessel (100 households) } \\
\text { 2. Primary drinking supply (as above) }\end{array}$ \\
\hline Outcomes & See Reller 2003-i \\
\hline Notes & See Reller 2003-i \\
\hline
\end{tabular}

Roberts 2001

\begin{tabular}{ll}
\hline Methods & Randomized controlled trial \\
\hline Participants & 1160 persons of all ages; of these, 208 were children $<5$ years \\
\hline Interventions & $\begin{array}{l}\text { 1. Improved storage: bucket with spout and narrow opening to limit hand entry (310 people including } 51 \text { children, } \\
100 \text { households) } \\
\text { 2. Primary drinking supply (850 people including } 157 \text { children, } 300 \text { households) }\end{array}$
\end{tabular}




\section{Roberts 2001 (Continued)}

\begin{tabular}{ll} 
Outcomes & $\begin{array}{l}\text { 1. Incidence of diarrhoea } \\
\text { 2. Microbiological water quality } \\
\text { 3. Incidence of diarrhoea by selected environmental factors }\end{array}$ \\
\hline Notes & $\begin{array}{l}\text { Location: Malawi refugee camp } \\
\text { Length: } 4 \text { months } \\
\text { Publication status: journal }\end{array}$ \\
\hline
\end{tabular}

Semenza 1998

\begin{tabular}{ll}
\hline Methods & Randomized controlled trial \\
\hline Participants & $\begin{array}{l}1583 \text { persons of all ages from } 240 \text { households, half with access to piped water (first control group) and half without } \\
\text { (of which } 62 \text { received intervention, and } 58 \text { served as a second control group); these included } 344 \text { children }<5 \text { (176 } \\
\text { from piped water households, } 88 \text { intervention and } 80 \text { no-chlorination) }\end{array}$ \\
\hline Interventions & $\begin{array}{l}\text { 1. Household level chlorination + vessel + hygiene education } \\
\text { 2. Primary drinking supply }\end{array}$ \\
\hline Outcomes & $\begin{array}{l}\text { 1. Incidence of diarrhoea } \\
\text { 2. Incidence of diarrhoea by selected household and water management practices }\end{array}$ \\
\hline Notes & $\begin{array}{l}\text { Location: urban Uzbekistan } \\
\text { Length: } 9.5 \text { weeks } \\
\text { Publication status: journal }\end{array}$ \\
\hline
\end{tabular}

\section{Torun 1982}

\begin{tabular}{|c|c|}
\hline Methods & Quasi-randomized controlled trial \\
\hline Participants & 2103 persons of all ages from 2 villages \\
\hline Interventions & $\begin{array}{l}\text { 1. Source protection (spring), chlorination facilities, "adequate storage", and water mains with faucets to yards of } \\
\text { intervention village ( } 1006 \text { people) } \\
\text { 2. Primary drinking supply ( } 1097 \text { people) }\end{array}$ \\
\hline Outcomes & 1. Incidence of diarrhoea \\
\hline Notes & $\begin{array}{l}\text { Location: } 2 \text { small villages in Guatemala } \\
\text { Length: } 12 \text { months } \\
\text { Publication status: book }\end{array}$ \\
\hline
\end{tabular}


URL 1995-i

\begin{tabular}{ll}
\hline Methods & Randomized controlled trial \\
\hline Participants & $\begin{array}{l}1120 \text { children }<5 \text { years }(265 \text { and } 289 \text { allocated to the water quality intervention arms, } 297 \text { to an education only } \\
\text { arm, and } 269 \text { to the control arm) from } 680 \text { families from three demographic regions }\end{array}$ \\
\hline Interventions & $\begin{array}{l}\text { 1. Locally fabricated ceramic filters (265 children or 23.6\%) } \\
\text { 2. Primary drinking supply (269 children) }\end{array}$ \\
\hline Outcomes & $\begin{array}{l}\text { 1. Incidence of diarrhoea } \\
\text { 2. Nutritional status (weight/age) }\end{array}$ \\
\hline Notes & $\begin{array}{l}\text { Location: } 3 \text { demographic regions of Guatemala } \\
\text { Length: } 12 \text { months } \\
\text { Publication status: unpublished }\end{array}$ \\
\hline
\end{tabular}

URL 1995-ii

\begin{tabular}{ll}
\hline Methods & See URL 1995-i \\
\hline Participants & See URL 1995-i \\
\hline Interventions & $\begin{array}{l}\text { 1. Locally fabricated ceramic filters + hygiene education } \\
\text { 2. Primary drinking supply (as above) }\end{array}$ \\
\hline Outcomes & See URL 1995-i \\
\hline Notes & See URL 1995-i \\
\hline
\end{tabular}

\section{Xiao 1997}

\begin{tabular}{ll}
\hline Methods & Quasi-randomized controlled trial \\
\hline Participants & 4649 persons of all ages \\
\hline Interventions & $\begin{array}{l}\text { 1. Improved water supply }+ \text { sanitation }+ \text { hygiene education (2363 people) } \\
\text { 2. Primary drinking supply }(2286 \text { people })\end{array}$ \\
\hline Outcomes & 1. Incidence of diarrhoea \\
\hline Notes & $\begin{array}{l}\text { Location: } 2 \text { villages in rural China } \\
\text { Length: } 3 \text { years } \\
\text { Publication status: journal }\end{array}$ \\
\hline
\end{tabular}

Interventions: details on controls and interventions in Appendix 3 and Appendix 4. 
Characteristics of excluded studies [ordered by study ID]

\begin{tabular}{|c|c|}
\hline Study & Reason for exclusion \\
\hline Asaolu 2002 & Study not RCT or quasi-RCT; outcome measures not include diarrhoea \\
\hline Azurin 1974 & Outcome measures not include diarrhoea \\
\hline Bahl 1976 & Study not RCT or quasi-RCT \\
\hline Bersh 1985 & Study not RCT or quasi-RCT \\
\hline Chongsuvivatwong 94 & Study not RCT or quasi-RCT \\
\hline Colwell 2003 & Outcome measures not include diarrhoea \\
\hline Conroy 2001 & Outcome measures not include diarrhoea \\
\hline Deb 1986 & Outcome measures not include diarrhoea \\
\hline Esrey $1991 \mathrm{~b}$ & Study not RCT or quasi-RCT \\
\hline Fewtrell 1994 & Study not RCT or quasi-RCT; outcome measures not include diarrhoea \\
\hline Fewtrell 1997 & Study not RCT or quasi-RCT; outcome measures not include diarrhoea \\
\hline Ghannoum 1981 & Study not RCT or quasi-RCT; outcome measures not include diarrhoea \\
\hline Hellard 2001 & Outcome measures not include diarrhoea \\
\hline Hoque 1996 & Study not RCT or quasi-RCT \\
\hline Iijima 2001 & Study not RCT or quasi-RCT \\
\hline Jensen 2002 & Outcome measures not include diarrhoea \\
\hline Khan 1984 & Outcome measures not include diarrhoea \\
\hline Macy 1998 & $\begin{array}{l}\text { Study not RCT or quasi-RCT; intervention not an improvement in water quality; outcome measures not } \\
\text { include diarrhoea }\end{array}$ \\
\hline Maeusezahl 2003 & Study not RCT or quasi-RCT \\
\hline McCabe 1957 & Intervention not an improvement in water quality \\
\hline Mertens 1990 & $\begin{array}{l}\text { Study not RCT or quasi-RCT; intervention not an improvement in water quality; outcome measures not } \\
\text { include diarrhoea }\end{array}$ \\
\hline Nanan 2003 & Study not RCT or quasi-RCT \\
\hline
\end{tabular}


(Continued)

\begin{tabular}{|c|c|}
\hline Payment 1991a & $\begin{array}{l}\text { Study not RCT or quasi-RCT } \\
\text { Outcome measures not include diarrhoea }\end{array}$ \\
\hline Payment 1991b & Outcome measures not include diarrhoea \\
\hline Pinfold 1990 & Intervention not an improvement in water quality; outcome measures not include diarrhoea \\
\hline Rubenstein 1969 & Study not RCT or quasi-RCT \\
\hline Sathe 1996 & Study not RCT or quasi-RCT \\
\hline Shiffman 1978 & Study not RCT or quasi-RCT \\
\hline Shum 1971 & $\begin{array}{l}\text { Study not RCT or quasi-RCT; intervention not an improvement in water quality; outcome measures not } \\
\text { include diarrhoea }\end{array}$ \\
\hline Sorvillo 1994 & Outcome measures not include diarrhoea \\
\hline Tonglet 1992 & Study not RCT or quasi-RCT \\
\hline Trivedi 1971 & Study not RCT or quasi-RCT \\
\hline VanDerslice 1995 & Study not RCT or quasi-RCT; intervention not an improvement in water quality \\
\hline Varghese 2002 & Study not RCT or quasi-RCT \\
\hline
\end{tabular}

RCT: randomized controlled trial

\section{Characteristics of studies awaiting assessment [ordered by study ID]}

\section{Clasen 2005}

Methods

Participants

Interventions

Outcomes

Notes 
Colford 2005a

Methods

Participants

Interventions

Outcomes

Notes

\section{Colford 2005b}

Methods

Participants

Interventions

Outcomes

Notes

Rose 2006

Methods

Participants

Interventions

Outcomes

Notes 
DATA ANDANALYSES

Comparison 1. Water quality intervention versus control: point and type of intervention (rate ratios)

\begin{tabular}{|c|c|c|c|c|}
\hline Outcome or subgroup title & $\begin{array}{l}\text { No. of } \\
\text { studies }\end{array}$ & $\begin{array}{c}\text { No. of } \\
\text { participants }\end{array}$ & Statistical method & Effect size \\
\hline 1 Diarrhoea: all ages & 10 & & Rate ratio (Random, 95\% CI) & Subtotals only \\
\hline $\begin{array}{l}\text { 1.1 Source or household } \\
\text { treatment }\end{array}$ & 10 & & Rate ratio (Random, 95\% CI) & $0.73[0.63,0.85]$ \\
\hline 1.2 Source treatment & 4 & & Rate ratio (Random, 95\% CI) & $0.87[0.74,1.02]$ \\
\hline 1.3 Household treatment & 6 & & Rate ratio (Random, 95\% CI) & $0.56[0.42,0.74]$ \\
\hline $\begin{array}{l}1.4 \text { Household treatment: } \\
\text { chlorination }\end{array}$ & 4 & & Rate ratio (Random, 95\% CI) & $0.61[0.46,0.81]$ \\
\hline $\begin{array}{l}1.5 \text { Household treatment: } \\
\text { filtration }\end{array}$ & 2 & & Rate ratio (Random, 95\% CI) & $0.37[0.15,0.92]$ \\
\hline 2 Diarrhoea: children $<5$ years & 6 & & Rate ratio (Random, 95\% CI) & Subtotals only \\
\hline $\begin{array}{l}2.1 \text { Source or household } \\
\text { treatment }\end{array}$ & 6 & & Rate ratio (Random, 95\% CI) & $0.78[0.65,0.94]$ \\
\hline 2.2 Source treatment & 3 & & Rate ratio (Random, 95\% CI) & $0.93[0.82,1.05]$ \\
\hline 2.3 Household treatment & 3 & & Rate ratio (Random, 95\% CI) & $0.42[0.19,0.95]$ \\
\hline $\begin{array}{l}2.4 \text { Household treatment: } \\
\text { chlorination }\end{array}$ & 2 & & Rate ratio (Random, 95\% CI) & $0.53[0.23,1.23]$ \\
\hline $\begin{array}{l}2.5 \text { Household treatment: } \\
\text { filtration }\end{array}$ & 1 & & Rate ratio (Random, 95\% CI) & $0.21[0.07,0.61]$ \\
\hline
\end{tabular}

Comparison 2. Water quality intervention versus control: point of intervention (risk ratios)

\begin{tabular}{|c|c|c|c|c|}
\hline Outcome or subgroup title & $\begin{array}{l}\text { No. of } \\
\text { studies }\end{array}$ & $\begin{array}{c}\text { No. of } \\
\text { participants }\end{array}$ & Statistical method & Effect size \\
\hline 1 Diarrhoea: all ages & 7 & & Risk ratio (Random, 95\% CI) & Subtotals only \\
\hline $\begin{array}{l}\text { 1.1 Source or household } \\
\text { treatment }\end{array}$ & 7 & & Risk ratio (Random, 95\% CI) & $0.45[0.33,0.62]$ \\
\hline 1.2 Source treatment & 1 & & Risk ratio (Random, 95\% CI) & $0.45[0.43,0.47]$ \\
\hline 1.3 Household treatment & 6 & & Risk ratio (Random, 95\% CI) & $0.43[0.27,0.70]$ \\
\hline $\begin{array}{l}1.4 \text { Household treatment: } \\
\text { chlorination }\end{array}$ & 3 & & Risk ratio (Random, 95\% CI) & $0.34[0.17,0.68]$ \\
\hline $\begin{array}{l}1.5 \text { Household treatment: } \\
\text { filtration }\end{array}$ & 2 & & Risk ratio (Random, 95\% CI) & $0.41[0.21,0.79]$ \\
\hline $\begin{array}{l}\text { 1.6 Household treatment: } \\
\text { improved storage }\end{array}$ & 1 & & Risk ratio (Random, 95\% CI) & $0.79[0.61,1.03]$ \\
\hline 2 Diarrhoea: children $<5$ years & 5 & & Risk ratio (Random, 95\% CI) & Subtotals only \\
\hline $\begin{array}{l}2.1 \text { Source or household } \\
\text { treatment }\end{array}$ & 5 & & Risk ratio (Random, 95\% CI) & $0.54[0.43,0.69]$ \\
\hline 2.2 Household treatment & 5 & & Risk ratio (Random, 95\% CI) & $0.54[0.43,0.69]$ \\
\hline
\end{tabular}


2.3 Household treatment: chlorination

2.4 Household treatment: filtration

2.5 Household treatment:

improved storage

Comparison 3. Water quality intervention versus control: point and type of intervention (longitudinal prevalence ratios)

\begin{tabular}{|c|c|c|c|c|}
\hline Outcome or subgroup title & $\begin{array}{l}\text { No. of } \\
\text { studies }\end{array}$ & $\begin{array}{c}\text { No. of } \\
\text { participants }\end{array}$ & Statistical method & Effect size \\
\hline 1 Diarrhoea: all ages & 11 & & Long. prev. ratio (Random, 95\% CI) & Subtotals only \\
\hline $\begin{array}{l}\text { 1.1 Source or household } \\
\text { treatment }\end{array}$ & 11 & & Long. prev. ratio (Random, 95\% CI) & $0.56[0.27,1.16]$ \\
\hline 1.2 Source treatment & 1 & & Long. prev. ratio (Random, 95\% CI) & $0.56[0.37,0.84]$ \\
\hline 1.3 Household treatment & 10 & & Long. prev. ratio (Random, 95\% CI) & $0.56[0.25,1.23]$ \\
\hline $\begin{array}{l}1.4 \text { Household treatment: } \\
\text { chlorination }\end{array}$ & 5 & & Long. prev. ratio (Random, 95\% CI) & $0.82[0.60,1.11]$ \\
\hline $\begin{array}{l}\text { 1.5 Household treatment: } \\
\text { flocculation and disinfection }\end{array}$ & 5 & & Long. prev. ratio (Random, 95\% CI) & $0.40[0.14,1.16]$ \\
\hline 2 Diarrhoea: children $<5$ years & 12 & & Long. prev. ratio (Random, 95\% CI) & Subtotals only \\
\hline $\begin{array}{l}2.1 \text { Source or household } \\
\text { treatment }\end{array}$ & 11 & & Long. prev. ratio (Random, 95\% CI) & $0.61[0.29,1.26]$ \\
\hline 2.2 Source treatment & 1 & & Long. prev. ratio (Random, 95\% CI) & $0.63[0.49,0.81]$ \\
\hline 2.3 Household treatment & 10 & & Long. prev. ratio (Random, 95\% CI) & $0.60[0.27,1.36]$ \\
\hline $\begin{array}{l}2.4 \text { Household treatment: } \\
\text { chlorination }\end{array}$ & 5 & & Long. prev. ratio (Random, 95\% CI) & $0.91[0.82,1.02]$ \\
\hline $\begin{array}{l}2.5 \text { Household treatment: } \\
\text { flocculation and disinfection }\end{array}$ & 5 & & Long. prev. ratio (Random, 95\% CI) & $0.42[0.13,1.37]$ \\
\hline
\end{tabular}

Comparison 4. Water quality intervention versus control: point and type of intervention (odds ratios)

\begin{tabular}{|c|c|c|c|c|}
\hline Outcome or subgroup title & $\begin{array}{l}\text { No. of } \\
\text { studies }\end{array}$ & $\begin{array}{c}\text { No. of } \\
\text { participants }\end{array}$ & Statistical method & Effect size \\
\hline 1 Diarrhoea: all ages & 9 & & Odds ratio (Random, 95\% CI) & Subtotals only \\
\hline $\begin{array}{l}1.1 \text { Source or household } \\
\text { treatment }\end{array}$ & 9 & & Odds ratio (Random, 95\% CI) & $0.68[0.59,0.79]$ \\
\hline 1.2 Household treatment & 9 & & Odds ratio (Random, 95\% CI) & $0.68[0.59,0.79]$ \\
\hline $\begin{array}{l}1.3 \text { Household treatment: } \\
\text { chlorination }\end{array}$ & 3 & & Odds ratio (Random, 95\% CI) & $0.77[0.58,1.02]$ \\
\hline $\begin{array}{l}1.4 \text { Household treatment: } \\
\text { filtration }\end{array}$ & 2 & & Odds ratio (Random, 95\% CI) & $0.35[0.23,0.53]$ \\
\hline
\end{tabular}




$\begin{array}{lllc}\begin{array}{c}1.5 \text { Household treatment: } \\ \text { solar disinfection }\end{array} & 2 & \text { Odds ratio (Random, 95\% CI) } & 0.69[0.63,0.74] \\ \begin{array}{c}1.6 \text { Household treatment: } \\ \text { flocculation and disinfection }\end{array} & 2 & \text { Odds ratio (Random, 95\% CI) } & 0.77[0.65,0.90] \\ \begin{array}{l}\text { Diarrhoea: children }<5 \text { years } \\ 2.1 \text { Source or household }\end{array} & 6 & \text { Odds ratio (Random, 95\% CI) } & \text { Subtotals only } \\ \begin{array}{l}\text { treatment } \\ 2.2 \text { Household treatment }\end{array} & 6 & \text { Odds ratio (Random, 95\% CI) } & 0.70[0.50,0.99] \\ 2.3 \text { Household treatment: } & 2 & \text { Odds ratio (Random, 95\% CI) } & 0.70[0.50,0.99] \\ \begin{array}{c}\text { chlorination } \\ 2.4 \text { Household treatment: }\end{array} & 2 & \text { Odds ratio (Random, 95\% CI) } & 0.90[0.65,1.25] \\ \text { filtration } & & \text { Odds ratio (Random, 95\% CI) } & 0.32[0.11,0.90] \\ 2.5 \text { Household treatment: } & 2 & \text { Odds ratio (Random, 95\% CI) } & 0.86[0.57,1.29] \\ \text { flocculation and disinfection } & & & \end{array}$

Comparison 5. Water quality intervention versus control: point and type of intervention (means ratios)

\begin{tabular}{|c|c|c|c|c|}
\hline Outcome or subgroup title & $\begin{array}{l}\text { No. of } \\
\text { studies }\end{array}$ & $\begin{array}{c}\text { No. of } \\
\text { participants }\end{array}$ & Statistical method & Effect size \\
\hline 1 Diarrhoea: all ages & 1 & & Means ratio (Random, 95\% CI) & Totals not selected \\
\hline $\begin{array}{l}\text { 1.1 Source or household } \\
\text { treatment }\end{array}$ & 1 & & Means ratio (Random, 95\% CI) & Not estimable \\
\hline 1.2 Household treatment & 1 & & Means ratio (Random, 95\% CI) & Not estimable \\
\hline $\begin{array}{l}1.3 \text { Household treatment: } \\
\text { chlorination }\end{array}$ & 1 & & Means ratio (Random, 95\% CI) & Not estimable \\
\hline 2 Diarrhoea: children $<5$ years & 1 & & Means ratio (Random, 95\% CI) & Totals not selected \\
\hline $\begin{array}{l}2.1 \text { Source or household } \\
\text { treatment }\end{array}$ & 1 & & Means ratio (Random, 95\% CI) & Not estimable \\
\hline 2.2 Household treatment & 1 & & Means ratio (Random, 95\% CI) & Not estimable \\
\hline $\begin{array}{l}2.3 \text { Household treatment: } \\
\text { chlorination }\end{array}$ & 1 & & Means ratio (Random, 95\% CI) & Not estimable \\
\hline
\end{tabular}

Comparison 6. Water quantity intervention versus control: by compliance with intervention (risk ratios)

\begin{tabular}{|c|c|c|c|c|}
\hline Outcome or subgroup title & $\begin{array}{l}\text { No. of } \\
\text { studies }\end{array}$ & $\begin{array}{c}\text { No. of } \\
\text { participants }\end{array}$ & Statistical method & Effect size \\
\hline 1 Diarrhoea: all ages & 4 & & Risk ratio (Random, 95\% CI) & Subtotals only \\
\hline $1.1<50 \%$ & 1 & & Risk ratio (Random, 95\% CI) & $0.44[0.28,0.69]$ \\
\hline $1.250 \%$ or $>$ & 3 & & Risk ratio (Random, 95\% CI) & $0.28[0.14,0.57]$ \\
\hline
\end{tabular}

Interventions to improve water quality for preventing diarrhoea (Review) 
Comparison 7. Water quality intervention versus control: by compliance with intervention (odds ratios)

\begin{tabular}{lcccc} 
Outcome or subgroup title & $\begin{array}{c}\text { No. of } \\
\text { studies }\end{array}$ & $\begin{array}{c}\text { No. of } \\
\text { participants }\end{array}$ & Statistical method & Effect size \\
\hline 1 Diarrhoea: all ages & 7 & Odds ratio (Random, 95\% CI) & Subtotals only \\
$1.1<50 \%$ & 4 & Odds ratio (Random, 95\% CI) & $0.80[0.71,0.89]$ \\
$1.250 \%$ or $>$ & 3 & Odds ratio (Random, 95\% CI) & $0.40[0.28,0.57]$ \\
\hline
\end{tabular}

Comparison 8. Water quality intervention versus control: by ambient water quality (rate ratios)

\begin{tabular}{|c|c|c|c|c|}
\hline Outcome or subgroup title & $\begin{array}{l}\text { No. of } \\
\text { studies }\end{array}$ & $\begin{array}{c}\text { No. of } \\
\text { participants }\end{array}$ & Statistical method & Effect size \\
\hline 1 Diarrhoea: all ages & 4 & & Rate ratio (Random, 95\% CI) & Subtotals only \\
\hline $\begin{array}{l}1.10 \text { colony-forming units } \\
\text { (CFU) }\end{array}$ & 1 & & Rate ratio (Random, 95\% CI) & $0.54[0.28,1.06]$ \\
\hline 1.210 to $99 \mathrm{CFU}$ & 3 & & Rate ratio (Random, 95\% CI) & $0.79[0.65,0.95]$ \\
\hline
\end{tabular}

Comparison 9. Water quality intervention versus control: by ambient water quality (risk ratios)

\begin{tabular}{|c|c|c|c|c|}
\hline Outcome or subgroup title & $\begin{array}{l}\text { No. of } \\
\text { studies }\end{array}$ & $\begin{array}{c}\text { No. of } \\
\text { participants }\end{array}$ & Statistical method & Effect size \\
\hline 1 Diarrhoea: all ages & 4 & & Risk ratio (Random, 95\% CI) & Subtotals only \\
\hline $\begin{array}{l}1.110 \text { to } 99 \text { colony-forming } \\
\text { units (CFU) }\end{array}$ & 2 & & Risk ratio (Random, 95\% CI) & $0.36[0.07,1.81]$ \\
\hline $1.2>99 \mathrm{CFU}$ & 2 & & Risk ratio (Random, 95\% CI) & $0.41[0.21,0.79]$ \\
\hline
\end{tabular}

Comparison 10. Water quality intervention versus control: by ambient water quality (longitudinal prevalence ratios)

\begin{tabular}{|c|c|c|c|c|}
\hline Outcome or subgroup title & $\begin{array}{l}\text { No. of } \\
\text { studies }\end{array}$ & $\begin{array}{c}\text { No. of } \\
\text { participants }\end{array}$ & Statistical method & Effect size \\
\hline 1 Diarrhoea: all ages & 5 & & Long. prev. ratio (Random, 95\% CI) & Subtotals only \\
\hline $\begin{array}{l}1.110 \text { to } 99 \text { colony-forming } \\
\text { units (CFU) }\end{array}$ & 2 & & Long. prev. ratio (Random, 95\% CI) & $0.80[0.69,0.93]$ \\
\hline $1.2>99 \mathrm{CFU}$ & 3 & & Long. prev. ratio (Random, 95\% CI) & $1.07[0.88,1.29]$ \\
\hline
\end{tabular}

Interventions to improve water quality for preventing diarrhoea (Review) 
Comparison 11. Water quality intervention versus control: by ambient water quality (odds ratios)

\begin{tabular}{lcccc} 
Outcome or subgroup title & $\begin{array}{c}\text { No. of } \\
\text { studies }\end{array}$ & $\begin{array}{c}\text { No. of } \\
\text { participants }\end{array}$ & Statistical method & Effect size \\
\hline 1 Diarrhoea: all ages & 22 & Odds ratio (Random, 95\% CI) & Subtotals only \\
1.10 colony-forming units & 1 & Odds ratio (Random, 95\% CI) & $0.54[0.28,1.06]$ \\
$(\mathrm{CFU})$ & 14 & & \\
1.210 to $99 \mathrm{CFU}$ & 7 & Odds ratio (Random, 95\% CI) & $0.70[0.60,0.80]$ \\
$1.3>99 \mathrm{CFU}$ & & Odds ratio (Random, 95\% CI) & $0.69[0.49,0.96]$ \\
\hline
\end{tabular}

Comparison 12. Water quality intervention versus control: by sufficiency of water quantity (long. prev. ratios)

\begin{tabular}{lcccc} 
Outcome or subgroup title & $\begin{array}{c}\text { No. of } \\
\text { studies }\end{array}$ & $\begin{array}{c}\text { No. of } \\
\text { participants }\end{array}$ & Statistical method & Effect size \\
\hline 1 Diarrhoea: all ages & 5 & Long. prev. ratio (Random, 95\% CI) & Subtotals only \\
1.1 Sufficient & 1 & Long. prev. ratio (Random, 95\% CI) & $0.62[0.47,0.82]$ \\
1.2 Insufficient & 4 & Long. prev. ratio (Random, 95\% CI) & $0.53[0.15,1.96]$ \\
\hline
\end{tabular}

Comparison 13. Water quality intervention versus control: by water supply level (rate ratios)

\begin{tabular}{|c|c|c|c|c|}
\hline Outcome or subgroup title & $\begin{array}{l}\text { No. of } \\
\text { studies }\end{array}$ & $\begin{array}{c}\text { No. of } \\
\text { participants }\end{array}$ & Statistical method & Effect size \\
\hline 1 Diarrhoea: all ages & 9 & & Rate ratio (Random, 95\% CI) & Subtotals only \\
\hline 1.1 Improved water supply & 3 & & Rate ratio (Random, 95\% CI) & $0.75[0.56,1.00]$ \\
\hline 1.2 Unimproved water supply & 6 & & Rate ratio (Random, 95\% CI) & $0.75[0.63,0.89]$ \\
\hline
\end{tabular}

Comparison 14. Water quality intervention versus control: by water supply level (risk ratios)

\begin{tabular}{|c|c|c|c|c|}
\hline Outcome or subgroup title & $\begin{array}{l}\text { No. of } \\
\text { studies }\end{array}$ & $\begin{array}{c}\text { No. of } \\
\text { participants }\end{array}$ & Statistical method & Effect size \\
\hline 1 Diarrhoea: all ages & 6 & & Risk ratio (Random, 95\% CI) & Subtotals only \\
\hline 1.1 Improved water supply & 3 & & Risk ratio (Random, 95\% CI) & $0.60[0.36,0.99]$ \\
\hline 1.2 Unimproved water supply & 3 & & Risk ratio (Random, 95\% CI) & $0.36[0.20,0.64]$ \\
\hline
\end{tabular}

Interventions to improve water quality for preventing diarrhoea (Review) 
Comparison 15. Water quality intervention versus control: by water supply level (longitudinal prevalence ratios)

\begin{tabular}{lcclc} 
Outcome or subgroup title & $\begin{array}{c}\text { No. of } \\
\text { studies }\end{array}$ & $\begin{array}{c}\text { No. of } \\
\text { participants }\end{array}$ & Statistical method & Effect size \\
\hline 1 Diarrhoea: all ages & 11 & Long. prev. ratio (Random, 95\% CI) & Subtotals only \\
1.1 Improved water supply & 4 & Long. prev. ratio (Random, 95\% CI) & $0.39[0.28,0.55]$ \\
1.2 Unimproved water supply & 7 & Long. prev. ratio (Random, 95\% CI) & $0.62[0.23,1.67]$ \\
\hline
\end{tabular}

Comparison 16. Water quality intervention versus control: by water supply level (odds ratios)

\begin{tabular}{|c|c|c|c|c|}
\hline Outcome or subgroup title & $\begin{array}{l}\text { No. of } \\
\text { studies }\end{array}$ & $\begin{array}{c}\text { No. of } \\
\text { participants }\end{array}$ & Statistical method & Effect size \\
\hline 1 Diarrhoea: all ages & 9 & & Odds ratio (Random, 95\% CI) & Subtotals only \\
\hline 1.1 Improved water supply & 1 & & Odds ratio (Random, 95\% CI) & $0.47[0.24,0.92]$ \\
\hline 1.2 Unimproved water supply & 8 & & Odds ratio (Random, 95\% CI) & $0.69[0.59,0.80]$ \\
\hline
\end{tabular}

Comparison 17. Water quality intervention versus control: by sanitation level (rate ratios)

\begin{tabular}{|c|c|c|c|c|}
\hline Outcome or subgroup title & $\begin{array}{l}\text { No. of } \\
\text { studies }\end{array}$ & $\begin{array}{c}\text { No. of } \\
\text { participants }\end{array}$ & Statistical method & Effect size \\
\hline 1 Diarrhoea: all ages & 7 & & Rate ratio (Random, 95\% CI) & Subtotals only \\
\hline 1.1 Improved sanitation & 4 & & Rate ratio (Random, 95\% CI) & $0.56[0.38,0.83]$ \\
\hline 1.2 Unimproved sanitation & 3 & & Rate ratio (Random, 95\% CI) & $0.80[0.64,1.00]$ \\
\hline
\end{tabular}

Comparison 18. Water quality intervention versus control: by sanitation level (risk ratios)

\begin{tabular}{lcll} 
Outcome or subgroup title & $\begin{array}{c}\text { No. of } \\
\text { studies }\end{array}$ & $\begin{array}{c}\text { No. of } \\
\text { participants }\end{array}$ & Statistical method \\
\hline 1 Diarrhoea: all ages & 4 & Risk ratio (Random, 95\% CI) & Subtotals only \\
1.1 Improved sanitation & 3 & Risk ratio (Random, 95\% CI) & $0.48[0.31,0.75]$ \\
1.2 Unimproved sanitation & 1 & Risk ratio (Random, 95\% CI) & $0.44[0.28,0.69]$ \\
\hline
\end{tabular}

Interventions to improve water quality for preventing diarrhoea (Review) 
Comparison 19. Water quality intervention versus control: by sanitation level (longitudinal prevalence ratios)

\begin{tabular}{lcccc} 
Outcome or subgroup title & $\begin{array}{c}\text { No. of } \\
\text { studies }\end{array}$ & $\begin{array}{c}\text { No. of } \\
\text { participants }\end{array}$ & Statistical method & Effect size \\
\hline 1 Diarrhoea: all ages & 7 & Long. prev. ratio (Random, 95\% CI) & Subtotals only \\
1.1 Improved sanitation & 4 & Long. prev. ratio (Random, 95\% CI) & $0.39[0.28,0.55]$ \\
1.2 Unimproved sanitation & 3 & Long. prev. ratio (Random, 95\% CI) & $0.43[0.09,2.09]$ \\
\hline
\end{tabular}

Comparison 20. Water quality intervention versus control: simple and compound interventions (rate ratios)

\begin{tabular}{|c|c|c|c|c|}
\hline Outcome or subgroup title & $\begin{array}{l}\text { No. of } \\
\text { studies }\end{array}$ & $\begin{array}{c}\text { No. of } \\
\text { participants }\end{array}$ & Statistical method & Effect size \\
\hline 1 Diarrhoea: all ages & 10 & & Risk ratio (Random, 95\% CI) & Subtotals only \\
\hline 1.1 Water quality only & 3 & & Risk ratio (Random, 95\% CI) & $0.55[0.26,1.17]$ \\
\hline $\begin{array}{l}1.2 \text { Water quality + hygiene } \\
\text { promotion }\end{array}$ & 3 & & Risk ratio (Random, 95\% CI) & $0.85[0.70,1.03]$ \\
\hline 1.3 Water quality + vessel & 4 & & Risk ratio (Random, 95\% CI) & $0.61[0.46,0.81]$ \\
\hline 1.4 Water quality + sanitation & 1 & & Risk ratio (Random, 95\% CI) & $0.75[0.70,0.80]$ \\
\hline $\begin{array}{l}1.5 \text { Water quality + improved } \\
\text { water supply }\end{array}$ & 2 & & Risk ratio (Random, 95\% CI) & $0.77[0.71,0.84]$ \\
\hline
\end{tabular}

Comparison 21. Water quality intervention versus control: simple and compound interventions (risk ratios)

\begin{tabular}{|c|c|c|c|c|}
\hline Outcome or subgroup title & $\begin{array}{l}\text { No. of } \\
\text { studies }\end{array}$ & $\begin{array}{c}\text { No. of } \\
\text { participants }\end{array}$ & Statistical method & Effect size \\
\hline 1 Diarrhoea: all ages & 6 & & Risk ratio (Random, 95\% CI) & Subtotals only \\
\hline 1.1 Water quality only & 2 & & Risk ratio (Random, 95\% CI) & $0.52[0.32,0.86]$ \\
\hline $\begin{array}{l}\text { 1.2 Water quality + hygiene } \\
\text { promotion }\end{array}$ & 3 & & Risk ratio (Random, 95\% CI) & $0.29[0.14,0.59]$ \\
\hline 1.3 Water quality + vessel & 2 & & Risk ratio (Random, 95\% CI) & $0.36[0.07,1.81]$ \\
\hline 1.4 Water quality + sanitation & 1 & & Risk ratio (Random, 95\% CI) & $0.44[0.28,0.69]$ \\
\hline $\begin{array}{l}1.5 \text { Water quality + improved } \\
\text { water supply }\end{array}$ & 1 & & Risk ratio (Random, 95\% CI) & $0.44[0.28,0.69]$ \\
\hline
\end{tabular}

Interventions to improve water quality for preventing diarrhoea (Review)

Copyright @ 2009 The Cochrane Collaboration. Published by John Wiley \& Sons, Ltd. 
Comparison 22. Water quality intervention versus control: simple and compound interventions (longitudinal prevalence ratios)

\begin{tabular}{lcccc} 
Outcome or subgroup title & $\begin{array}{c}\text { No. of } \\
\text { studies }\end{array}$ & $\begin{array}{c}\text { No. of } \\
\text { participants }\end{array}$ & Statistical method & Effect size \\
\hline 1 Diarrhoea: all ages & 11 & Long. prev. ratio (Random, 95\% CI) & Subtotals only \\
1.1 Water quality only & 3 & Long. prev. ratio (Random, 95\% CI) & $1.07[0.88,1.29]$ \\
1.2 Water quality + hygiene & 4 & Long. prev. ratio (Random, 95\% CI) & $0.71[0.59,0.86]$ \\
promotion & & & \\
1.3 Water quality + vessel & 3 & Long. prev. ratio (Random, 95\% CI) & $0.26[0.10,0.69]$ \\
1.4 Water quality + sanitation & 1 & Long. prev. ratio (Random, 95\% CI) & $0.56[0.37,0.84]$ \\
1.5 Water quality + improved & 1 & Long. prev. ratio (Random, 95\% CI) & $0.56[0.37,0.84]$ \\
water supply & & & \\
\hline
\end{tabular}

Comparison 23. Water quality intervention versus control: simple and compound interventions (odds ratios)

\begin{tabular}{lcccc} 
Outcome or subgroup title & $\begin{array}{c}\text { No. of } \\
\text { studies }\end{array}$ & $\begin{array}{c}\text { No. of } \\
\text { participants }\end{array}$ & Statistical method & Effect size \\
\hline 1 Diarrhoea: all ages & 13 & Odds ratio (Random, 95\% CI) & Subtotals only \\
1.1 Water quality only & 6 & Odds ratio (Random, 95\% CI) & $0.64[0.53,0.77]$ \\
1.2 Water quality + hygiene & 1 & Odds ratio (Random, 95\% CI) & $0.52[0.30,0.90]$ \\
promotion & & & \\
1.3 Water quality + vessel & 3 & Odds ratio (Random, 95\% CI) & $0.77[0.58,1.03]$ \\
1.4 Water quality + sanitation & 3 & Odds ratio (Random, 95\% CI) & $0.60[0.43,0.84]$ \\
1.5 Water quality + improved & 4 & Odds ratio (Random, 95\% CI) & $0.70[0.59,0.84]$ \\
water supply & & & \\
\hline
\end{tabular}

Comparison 24. Water quality intervention versus control for RCTs: by methodological quality (rate ratios)

\begin{tabular}{|c|c|c|c|c|}
\hline Outcome or subgroup title & $\begin{array}{l}\text { No. of } \\
\text { studies }\end{array}$ & $\begin{array}{c}\text { No. of } \\
\text { participants }\end{array}$ & Statistical method & Effect size \\
\hline $\begin{array}{l}1 \text { Diarrhoea: by allocation } \\
\text { sequence }\end{array}$ & 4 & & Rate ratio (Random, 95\% CI) & Subtotals only \\
\hline 1.1 Adequate & 2 & & Rate ratio (Random, 95\% CI) & $0.37[0.15,0.92]$ \\
\hline 1.2 Unclear & 2 & & Rate ratio (Random, 95\% CI) & $0.73[0.61,0.87]$ \\
\hline $\begin{array}{l}2 \text { Diarrhoea: by allocation } \\
\text { concealment }\end{array}$ & 8 & & Rate ratio (Random, 95\% CI) & Subtotals only \\
\hline 2.1 Adequate & 4 & & Rate ratio (Random, 95\% CI) & $0.65[0.49,0.86]$ \\
\hline 2.2 Inadequate & 4 & & Rate ratio (Random, 95\% CI) & $0.79[0.63,0.99]$ \\
\hline 3 Diarrhoea: by follow up & 18 & & Rate ratio (Random, 95\% CI) & Subtotals only \\
\hline 3.1 Adequate & 4 & & Rate ratio (Random, 95\% CI) & $0.65[0.49,0.86]$ \\
\hline 3.2 Unclear & 3 & & Rate ratio (Random, 95\% CI) & $0.28[0.14,0.57]$ \\
\hline 3.3 Inadequate & 11 & & Rate ratio (Random, 95\% CI) & $0.81[0.73,0.89]$ \\
\hline
\end{tabular}


4 Diarrhoea: by blinding 4.1 Double blind 4.2 Open
Rate ratio (Random, 95\% CI)

Rate ratio (Random, 95\% CI)

Rate ratio (Random, 95\% CI)
Subtotals only

$0.54[0.28,1.06]$

$0.66[0.47,0.92]$

Comparison 25. Water quality intervention versus control for RCTs: by methodological quality (risk ratios)

\begin{tabular}{|c|c|c|c|c|}
\hline Outcome or subgroup title & $\begin{array}{l}\text { No. of } \\
\text { studies }\end{array}$ & $\begin{array}{c}\text { No. of } \\
\text { participants }\end{array}$ & Statistical method & Effect size \\
\hline $\begin{array}{l}1 \text { Diarrhoea: by allocation } \\
\text { sequence }\end{array}$ & 4 & & Risk ratio (Random, 95\% CI) & Subtotals only \\
\hline 1.1 Adequate & 3 & & Risk ratio (Random, 95\% CI) & $0.28[0.14,0.57]$ \\
\hline 1.2 Inadequate & 1 & & Risk ratio (Random, 95\% CI) & $0.79[0.61,1.03]$ \\
\hline $\begin{array}{l}2 \text { Diarrhoea: by allocation } \\
\text { concealment }\end{array}$ & 4 & & Risk ratio (Random, 95\% CI) & Subtotals only \\
\hline 2.1 Adequate & 3 & & Risk ratio (Random, 95\% CI) & $0.28[0.14,0.57]$ \\
\hline 2.2 Inadequate & 1 & & Risk ratio (Random, 95\% CI) & $0.79[0.61,1.03]$ \\
\hline 3 Diarrhoea: by follow up & 4 & & Risk ratio (Random, 95\% CI) & Subtotals only \\
\hline 3.1 Unclear & 3 & & Risk ratio (Random, 95\% CI) & $0.28[0.14,0.57]$ \\
\hline 3.2 Inadequate & 1 & & Risk ratio (Random, 95\% CI) & $0.79[0.61,1.03]$ \\
\hline 4 Diarrhoea: by blinding & 4 & & Risk ratio (Random, 95\% CI) & Subtotals only \\
\hline 4.1 Open & 4 & & Risk ratio (Random, 95\% CI) & $0.39[0.17,0.90]$ \\
\hline
\end{tabular}

Comparison 26. Water quality intervention versus control for RCTs: by methodological quality (longitudinal prevalence ratios)

\begin{tabular}{|c|c|c|c|c|}
\hline Outcome or subgroup title & $\begin{array}{l}\text { No. of } \\
\text { studies }\end{array}$ & $\begin{array}{c}\text { No. of } \\
\text { participants }\end{array}$ & Statistical method & Effect size \\
\hline 1 Diarrhoea: allocation sequence & 10 & & Long. prev. ratio (Random, 95\% CI) & Subtotals only \\
\hline 1.1 Adequate & 9 & & Long. prev. ratio (Random, 95\% CI) & $0.51[0.23,1.14]$ \\
\hline 1.2 Inadequate & 1 & & Long. prev. ratio (Random, 95\% CI) & $1.07[0.88,1.30]$ \\
\hline $\begin{array}{l}2 \text { Diarrhoea: by allocation } \\
\text { concealment }\end{array}$ & 10 & & Long. prev. ratio (Random, 95\% CI) & Subtotals only \\
\hline 2.1 Adequate & 9 & & Long. prev. ratio (Random, 95\% CI) & $0.51[0.23,1.14]$ \\
\hline 2.2 Inadequate & 1 & & Long. prev. ratio (Random, 95\% CI) & $1.07[0.88,1.30]$ \\
\hline 3 Diarrhoea: by follow up & 9 & & Long. prev. ratio (Random, 95\% CI) & Subtotals only \\
\hline 3.1 Adequate & 4 & & Long. prev. ratio (Random, 95\% CI) & $0.54[0.43,0.67]$ \\
\hline 3.2 Inadequate & 5 & & Long. prev. ratio (Random, 95\% CI) & $0.89[0.76,1.04]$ \\
\hline 4 Diarrhoea: by blinding & 10 & & Long. prev. ratio (Random, 95\% CI) & Subtotals only \\
\hline 4.1 Double blind & 3 & & Long. prev. ratio (Random, 95\% CI) & $1.07[0.88,1.29]$ \\
\hline 4.2 Open & 7 & & Long. prev. ratio (Random, 95\% CI) & $0.45[0.18,1.08]$ \\
\hline
\end{tabular}




\begin{tabular}{|c|c|c|c|c|}
\hline Outcome or subgroup title & $\begin{array}{l}\text { No. of } \\
\text { studies }\end{array}$ & $\begin{array}{c}\text { No. of } \\
\text { participants }\end{array}$ & Statistical method & Effect size \\
\hline $\begin{array}{l}1 \text { Diarrhoea: by allocation } \\
\text { sequence }\end{array}$ & 9 & & Odds ratio (Random, 95\% CI) & Subtotals only \\
\hline 1.1 Adequate & 7 & & Odds ratio (Random, 95\% CI) & $0.66[0.52,0.83]$ \\
\hline 1.2 Inadequate & 2 & & Odds ratio (Random, 95\% CI) & $0.69[0.63,0.74]$ \\
\hline $\begin{array}{l}2 \text { Diarrhoea: by allocation } \\
\text { concealment }\end{array}$ & 9 & & Odds ratio (Random, 95\% CI) & Subtotals only \\
\hline 2.1 Adequate & 7 & & Odds ratio (Random, 95\% CI) & $0.66[0.52,0.83]$ \\
\hline 2.2 Inadequate & 2 & & Odds ratio (Random, 95\% CI) & $0.69[0.63,0.74]$ \\
\hline 3 Diarrhoea: by follow up & 9 & & Odds ratio (Random, 95\% CI) & Subtotals only \\
\hline 3.1 Adequate & 4 & & Odds ratio (Random, 95\% CI) & $0.48[0.32,0.71]$ \\
\hline 3.2 Inadequate & 5 & & Odds ratio (Random, 95\% CI) & $0.75[0.68,0.84]$ \\
\hline 4 Diarrhoea: by blinding & 9 & & Odds ratio (Random, 95\% CI) & Subtotals only \\
\hline 4.1 Open & 9 & & Odds ratio (Random, 95\% CI) & $0.68[0.59,0.79]$ \\
\hline
\end{tabular}

Comparison 28. Water quality intervention versus control for quasi-RCTs: by methodological quality (rate ratios)

\begin{tabular}{|c|c|c|c|c|}
\hline Outcome or subgroup title & $\begin{array}{l}\text { No. of } \\
\text { studies }\end{array}$ & $\begin{array}{c}\text { No. of } \\
\text { participants }\end{array}$ & Statistical method & Effect size \\
\hline $\begin{array}{l}1 \text { Diarrhoea: by comparability of } \\
\text { characteristics }\end{array}$ & 6 & & Rate ratio (Random, 95\% CI) & Subtotals only \\
\hline 1.1 Adequate & 4 & & Rate ratio (Random, 95\% CI) & $0.67[0.54,0.83]$ \\
\hline 1.2 Unclear & 1 & & Rate ratio (Random, 95\% CI) & $1.0[0.89,1.12]$ \\
\hline 1.3 Inadequate & 1 & & Rate ratio (Random, 95\% CI) & $0.94[0.73,1.21]$ \\
\hline $\begin{array}{l}2 \text { Diarrhoea: by contemporaneous } \\
\text { of data collection }\end{array}$ & 11 & & Rate ratio (Random, 95\% CI) & Subtotals only \\
\hline 2.1 Adequate & 10 & & Rate ratio (Random, 95\% CI) & $0.59[0.46,0.75]$ \\
\hline 2.2 Unclear & 1 & & Rate ratio (Random, 95\% CI) & $1.0[0.89,1.12]$ \\
\hline
\end{tabular}

Comparison 29. Water quality intervention versus control for quasi-RCTs: by methodological quality (risk ratios)

\begin{tabular}{|c|c|c|c|c|}
\hline Outcome or subgroup title & $\begin{array}{l}\text { No. of } \\
\text { studies }\end{array}$ & $\begin{array}{c}\text { No. of } \\
\text { participants }\end{array}$ & Statistical method & Effect size \\
\hline $\begin{array}{l}1 \text { Diarrhoea: by comparability of } \\
\text { characteristics }\end{array}$ & 3 & & Risk ratio (Random, 95\% CI) & Subtotals only \\
\hline 1.1 Adequate & 2 & & Risk ratio (Random, 95\% CI) & $0.45[0.43,0.47]$ \\
\hline 1.2 Inadequate & 1 & & Risk ratio (Random, 95\% CI) & $0.44[0.28,0.69]$ \\
\hline $\begin{array}{l}2 \text { Diarrhoea: by contemporaneous } \\
\text { of data collection }\end{array}$ & 11 & & Risk ratio (Random, 95\% CI) & Subtotals only \\
\hline 2.1 Adequate & 10 & & Risk ratio (Random, 95\% CI) & $0.59[0.46,0.75]$ \\
\hline
\end{tabular}

Interventions to improve water quality for preventing diarrhoea (Review) 
Analysis I.I. Comparison I Water quality intervention versus control: point and type of intervention (rate ratios), Outcome I Diarrhoea: all ages.

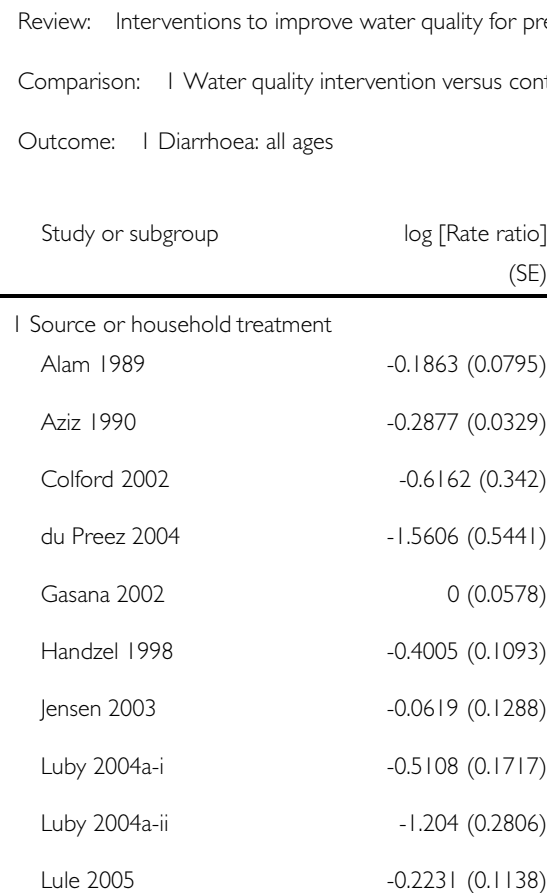

Subtotal $(95 \% \mathrm{CI})$

Heterogeneity: Tau $^{2}=0.03 ; \mathrm{Chi}^{2}=45.26, \mathrm{df}=9(\mathrm{P}<0.0000 \mathrm{I}) ; \mathrm{I}^{2}=80 \%$

Test for overall effect: $Z=4.14(P=0.000035)$

2 Source treatment

$\begin{array}{lr}\text { Alam } 1989 & -0.1863(0.0795) \\ \text { Aziz } 1990 & -0.2877(0.0329) \\ \text { Gasana } 2002 & 0(0.0578) \\ \text { Jensen } 2003 & -0.0619(0.1288)\end{array}$

Subtotal $(95 \% \mathrm{CI})$

Heterogeneity: $\mathrm{Tau}^{2}=0.02 ; \mathrm{Chi}^{2}=20.18, \mathrm{df}=3(\mathrm{P}=0.00016) ; \mathrm{I}^{2}=85 \%$

Test for overall effect: $Z=1.71(P=0.088)$

3 Household treatment

Colford 2002

$-0.6162(0.342)$

du Preez 2004

$-1.5606(0.544 \mid)$

Rate ratio IV,Random,95\% Cl

Weight

Rate ratio V,Random,95\% Cl

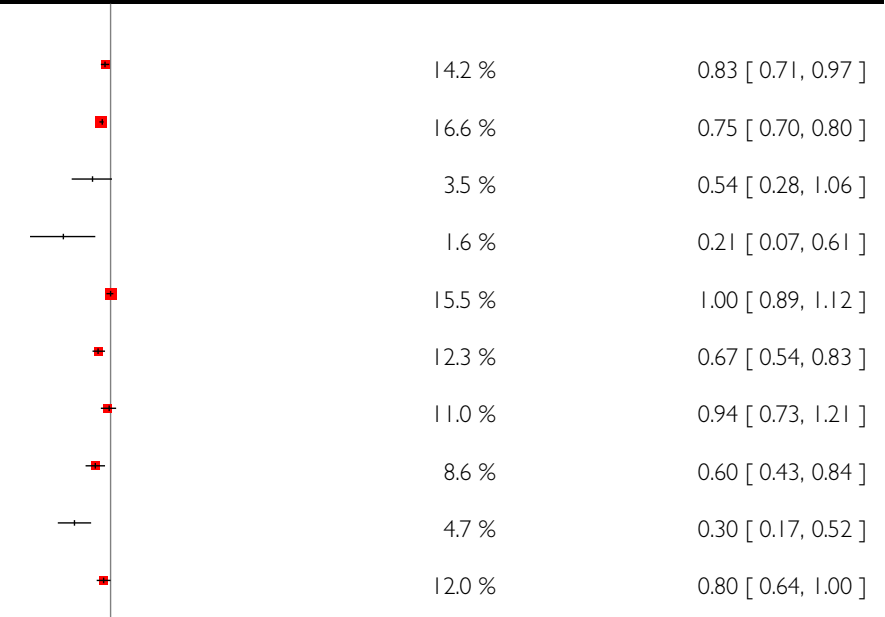

$100.0 \%$

$0.73[0.63,0.85]$

$\begin{array}{lr}24.8 \% & 0.83[0.71,0.97] \\ 29.0 \% & 0.75[0.70,0.80] \\ 27.0 \% & 1.00[0.89,1.12] \\ 19.3 \% & 0.94[0.73,1.21] \\ \mathbf{0 . 0} \% & \mathbf{0 . 8 7}[\mathbf{0 . 7 4 , \mathbf { 1 . 0 2 }}]\end{array}$

$100.0 \%$

$0.87[0.74,1.02]$ 


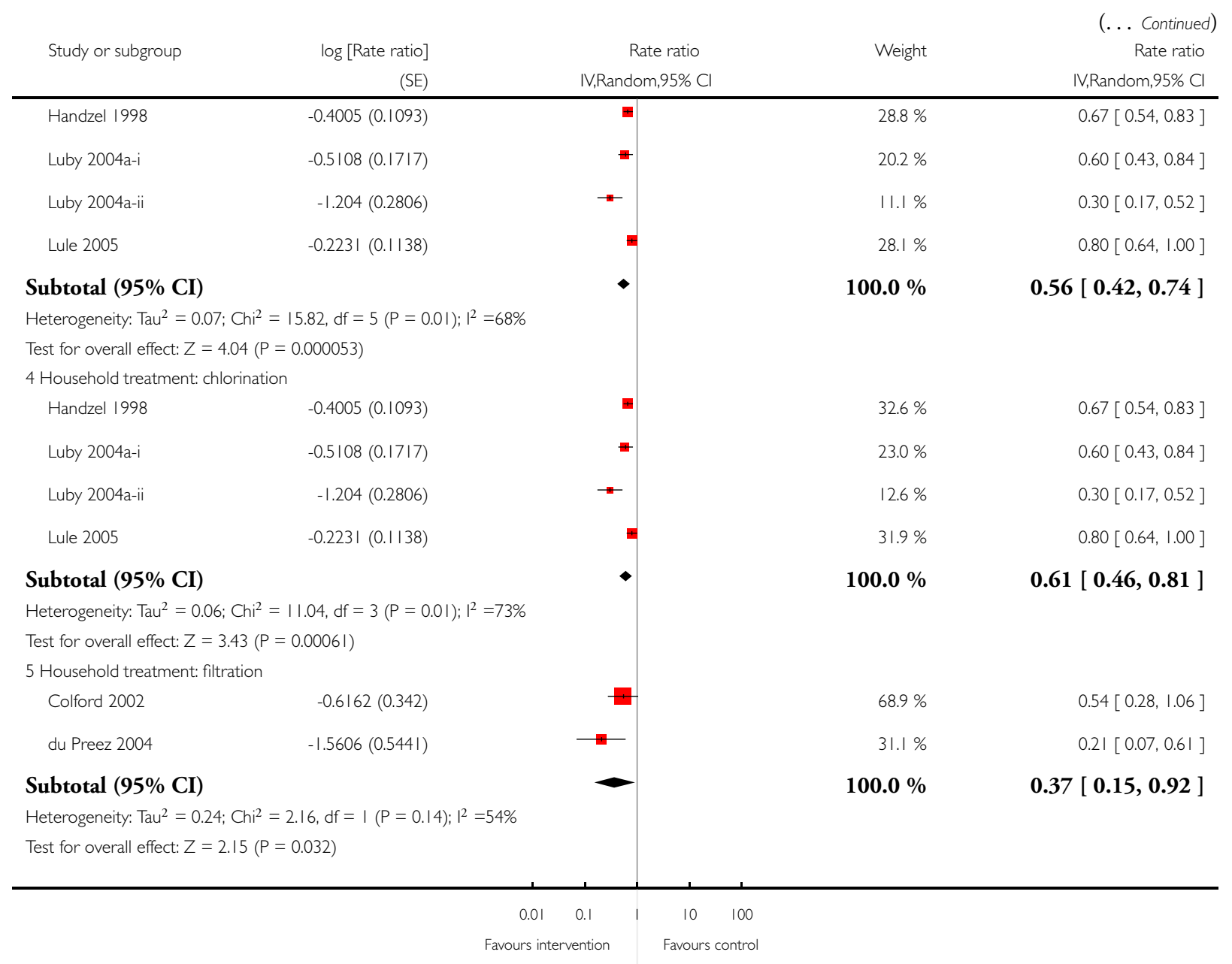


Analysis I.2. Comparison I Water quality intervention versus control: point and type of intervention (rate ratios), Outcome 2 Diarrhoea: children $<5$ years.

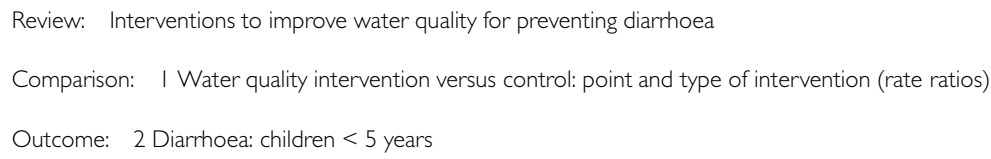

(

Subtotal $(95 \% \mathrm{CI})$

Heterogeneity: $\mathrm{Tau}^{2}=0.03 ; \mathrm{Chi}^{2}=32.35, \mathrm{df}=5(\mathrm{P}<0.0000 \mathrm{I}) ; \mathrm{I}^{2}=85 \%$ Test for overall effect: $Z=2.61(P=0.0091)$

2 Source treatment

$$
\begin{array}{lr}
\text { Alam } 1989 & -0.1863(0.0795) \\
\text { Gasana } 2002 & 0(0.0578) \\
\text { Jensen } 2003 & -0.0619(0.1288)
\end{array}
$$

\section{Subtotal $(95 \%$ CI $)$}

Heterogeneity: $\operatorname{Tau}^{2}=0.01 ; \mathrm{Chi}^{2}=3.59, \mathrm{df}=2(\mathrm{P}=0.17) ; \mathrm{I}^{2}=44 \%$

Test for overall effect: $Z=1.19(P=0.23)$

3 Household treatment

$\begin{array}{ll}\text { du Preez } 2004 & -1.5606(0.5441) \\ \text { Handzel } 1998 & -0.2485(0.0317) \\ \text { Semenza } 1998 & -1.1087(0.2788)\end{array}$

\section{Subtotal $(95 \% \mathrm{CI})$}

Heterogeneity: Tau $^{2}=0.41 ; \mathrm{Chi}^{2}=15.10, \mathrm{df}=2(\mathrm{P}=0.00053) ; \mathrm{I}^{2}=87 \%$ Test for overall effect: $Z=2.10(P=0.036)$

4 Household treatment: chlorination

$$
\begin{array}{ll}
\text { Handzel } 1998 & -0.2485(0.0317) \\
\text { Semenza } 1998 & -1.1087(0.2788)
\end{array}
$$

Subtotal $(\mathbf{9 5 \%} \mathrm{CI})$

Heterogeneity: $\mathrm{Tau}^{2}=0.33 ; \mathrm{Chi}^{2}=9.40, \mathrm{df}=\mathrm{I}(\mathrm{P}=0.002) ; \mathrm{I}^{2}=89 \%$

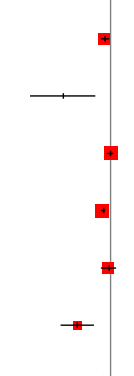

$22.5 \%$

$1.9 \%$

$25.2 \%$

$27.8 \%$

$16.3 \%$

$6.2 \%$

$100.0 \%$

$35.1 \%$

$39.4 \%$

$25.5 \%$

$100.0 \%$

$5.4 \%$

$77.3 \%$

$17.3 \%$

$100.0 \%$

$81.7 \%$

$18.3 \%$

$100.0 \%$
$0.83[0.71,0.97]$

$0.21[0.07,0.61]$

$1.00[0.89,1.12]$

$0.78[0.73,0.83]$

$0.94[0.73,1.21]$

$0.33[0.19,0.57]$

$0.78[0.65,0.94]$

$0.83[0.71,0.97]$

$1.00[0.89,1.12]$

$0.94[0.73,1.21]$

$0.93[0.82,1.05]$

$0.21[0.07,0.61]$

$0.78[0.73,0.83]$

$0.33[0.19,0.57]$

$0.42[0.19,0.95]$

$0.78[0.73,0.83]$

$0.33[0.19,0.57]$

$0.53[0.23,1.23]$

(Continued ....)

Interventions to improve water quality for preventing diarrhoea (Review)

Copyright @ 2009 The Cochrane Collaboration. Published by John Wiley \& Sons, Ltd. 
Study or subgroup log [Rate ratio]

(SE)

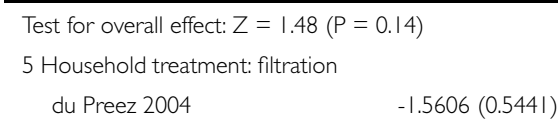

Subtotal (95\% CI)

Heterogeneity: not applicable

Test for overall effect: $Z=2.87(P=0.0041)$
(... Continued)

Rate ratio

IV,Random,95\% Cl

IV,Random,95\% Cl

$100.0 \%$

$0.21[0.07,0.61]$

$100.0 \%$

$0.21[0.07,0.61]$

\section{Analysis 2.I. Comparison 2 Water quality intervention versus control: point of intervention (risk ratios),}

Outcome I Diarrhoea: all ages.

Review: Interventions to improve water quality for preventing diarrhoea

Comparison: 2 Water quality intervention versus control: point of intervention (risk ratios)

Outcome: I Diarrhoea: all ages

Study or subgroup $\quad \log$ [Risk ratio] Risk ratio Reight ratio

(SE) IV,Random,95\% Cl
IV,Random,95\% Cl

I Source or household treatment

Garrett 2004

$-0.821(0.2295)$

Mahfouz 1995

$-0.5978(0.305)$

Roberts 2001

$-0.2357(0.1353)$

Semenza 1998

$-1.897 \mid(0.3704)$

URL 1995-i

$-0.755(0.4476)$

URL 1995-ii

$-1.0498(0.4931)$

Xiao 1997

$-0.7985(0.0222)$

\section{Subtotal $(\mathbf{9 5 \%}$ CI)}

Heterogeneity: $\mathrm{Tau}^{2}=0.1 \mathrm{I} ; \mathrm{Chi}^{2}=26.55, \mathrm{df}=6(\mathrm{P}=0.000 \mathrm{I}) ; \mathrm{I}^{2}=77 \%$

Test for overall effect: $Z=4.95(P<0.0000 \mathrm{I})$

2 Source treatment

N,Random, $95 \%$ Cl

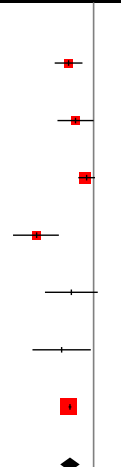

$\checkmark$
$13.0 \%$

$8.6 \%$

$23.5 \%$

$6.2 \%$

$4.5 \%$

$3.8 \%$

$40.4 \%$

$100.0 \%$
$0.44[0.28,0.69]$

$0.55[0.30,1.00]$

$0.79[0.61,1.03]$

$0.15[0.07,0.31]$

$0.47[0.20,1.13]$

$0.35[0.13,0.92]$

$0.45[0.43,0.47]$

0.45 [ $0.33,0.62$ ]
(Continued....) 


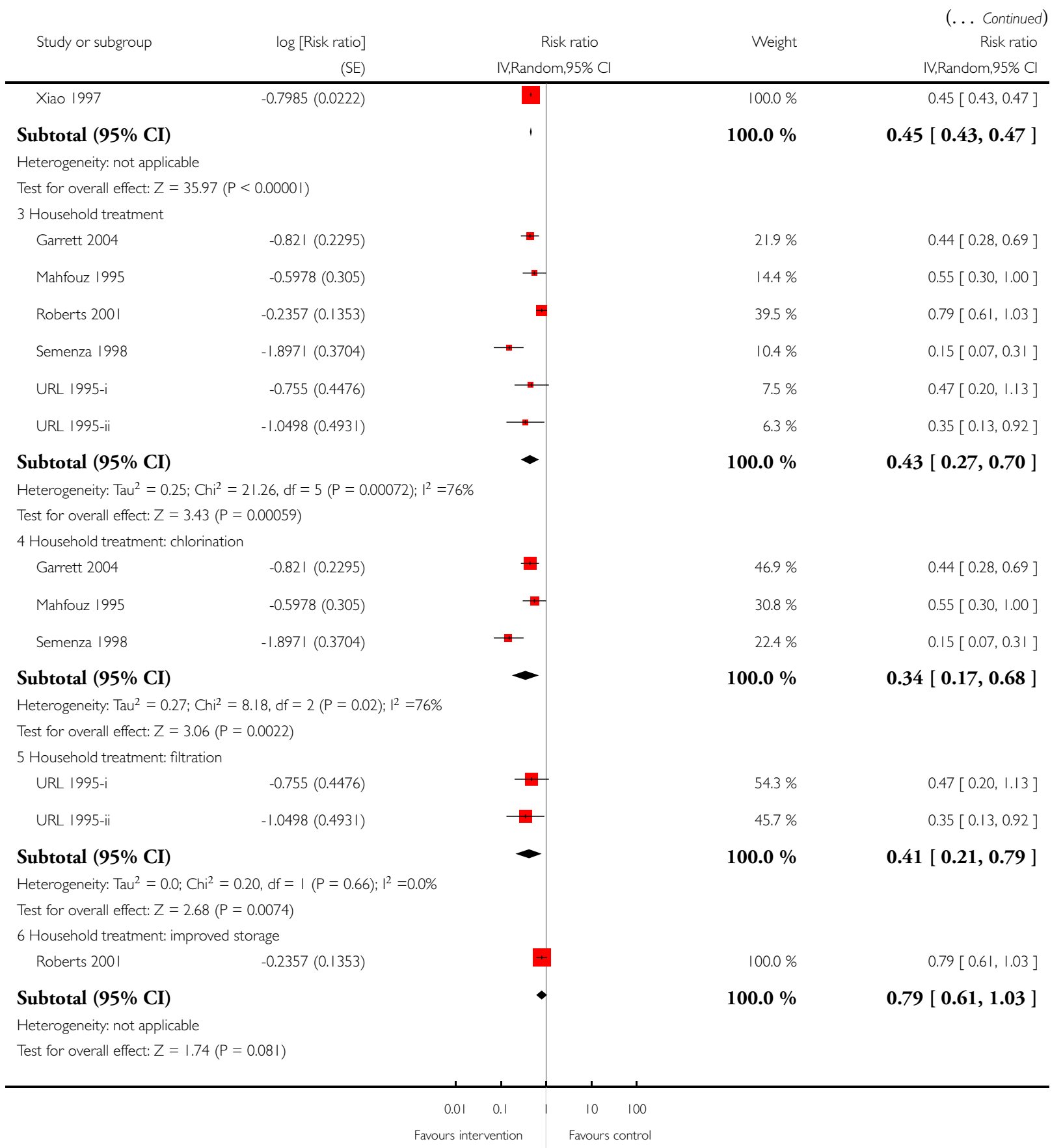




\section{Analysis 2.2. Comparison 2 Water quality intervention versus control: point of intervention (risk ratios), Outcome 2 Diarrhoea: children $<5$ years.}

Review: Interventions to improve water quality for preventing diarrhoea

Comparison: 2 Water quality intervention versus control: point of intervention (risk ratios)

Outcome: 2 Diarrhoea: children $<5$ years

Study or subgroup $\quad$ log [Risk ratio] Risk ratio Risk ratio

(SE) IV,Random,95\% Cl
$\mathrm{V}, \mathrm{Random}, 95 \% \mathrm{Cl}$

$\begin{array}{ll}\begin{array}{l}\text { I Source or household treatment } \\ \text { Garrett 2004 }\end{array} & -0.82 \text { | (0.2295) } \\ \text { Mahfouz I995 } & -0.5978(0.305) \\ \text { Roberts 200 I } & -0.37 \text { I I (0.1944) } \\ \text { URL 1995-i } & -0.755(0.4476) \\ \text { URL 1995-ii } & -1.0498(0.493 \text { I) }\end{array}$

Subtotal $(\mathbf{9 5 \%} \mathrm{CI})$

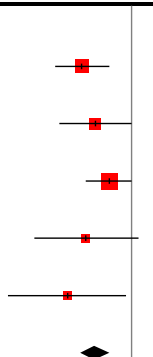

Heterogeneity: $\mathrm{Tau}^{2}=0.0 ; \mathrm{Chi}^{2}=3.26, \mathrm{df}=4(\mathrm{P}=0.52) ; \mathrm{I}^{2}=0.0 \%$

Test for overall effect: $Z=4.94(P<0.0000$ I)

2 Household treatment

$\begin{array}{lc}\text { Garrett } 2004 & -0.82 \text { I }(0.2295) \\ \text { Mahfouz I995 } & -0.5978(0.305) \\ \text { Roberts 200 I } & -0.37 \text { II }(0.1944) \\ \text { URL 1995-i } & -0.755(0.4476) \\ \text { URL 1995-ii } & -1.0498(0.493 \text { I) }\end{array}$

Subtotal $(95 \% \mathrm{CI})$

Heterogeneity: $\operatorname{Tau}^{2}=0.0 ; \mathrm{Chi}^{2}=3.26, \mathrm{df}=4(\mathrm{P}=0.52) ; \mathrm{I}^{2}=0.0 \%$

Test for overall effect: $Z=4.94(P<0.0000 \mathrm{I})$

3 Household treatment: chlorination

$\begin{array}{ll}\text { Garrett } 2004 & -0.821(0.2295) \\ \text { Mahfouz } 1995 & -0.5978(0.305)\end{array}$

Subtotal $(\mathbf{9 5 \%} \mathrm{CI})$

Heterogeneity: $\mathrm{Tau}^{2}=0.0 ; \mathrm{Chi}^{2}=0.34, \mathrm{df}=\mathrm{I}(\mathrm{P}=0.56) ; \mathrm{I}^{2}=0.0 \%$

Test for overall effect: $Z=4.04(P=0.000054)$

4 Household treatment: filtration
URL 1995-i
$-0.755(0.4476)$
URL 1995-ii
$-1.0498(0.4931)$

Subtotal $(\mathbf{9 5 \%}$ CI)

Heterogeneity: $\mathrm{Tau}^{2}=0.0 ; \mathrm{Chi}^{2}=0.20, \mathrm{df}=\mathrm{I}(\mathrm{P}=0.66) ; \mathrm{I}^{2}=0.0 \%$

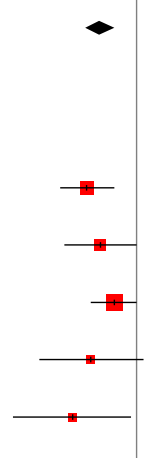

$\begin{array}{ll}29.1 \% & 0.44[0.28,0.69] \\ 16.5 \% & 0.55[0.30,1.00] \\ 40.5 \% & 0.69[0.47,1.01] \\ 7.6 \% & 0.47[0.20,1.13] \\ 6.3 \% & 0.35[0.13,0.92]\end{array}$

$100.0 \%$

$0.54[0.43,0.69]$

$29.1 \%$

$0.44[0.28,0.69]$

$16.5 \%$

$0.55[0.30,1.00]$

$40.5 \%$

$0.69[0.47,1.01]$

$7.6 \%$

$0.47[0.20,1.13]$

$6.3 \%$

$0.35[0.13,0.92]$

$100.0 \%$

0.54 [ $0.43,0.69$ ]

$63.8 \%$

$0.44[0.28,0.69]$

$36.2 \%$

$0.55[0.30,1.00]$

$100.0 \%$

$0.48[0.33,0.68$ ]

$54.8 \%$

$0.47[0.20,1.13]$

$45.2 \%$

$0.35[0.13,0.92]$

$100.0 \%$

$0.41[0.21,0.79$ ]

$\begin{array}{lllllll}0.1 & 0.2 & 0.5 & 1 & 2 & 5 & 10\end{array}$

Favours intervention Favours control

(Continued ... )

Interventions to improve water quality for preventing diarrhoea (Review) 
Test for overall effect: $Z=2.68(P=0.0074)$

5 Household treatment: improved storage

$$
\text { Roberts 200I } \quad-0.37 \text { II (0.1944) }
$$

Subtotal (95\% CI)

\section{Analysis 3.I. Comparison 3 Water quality intervention versus control: point and type of intervention} (longitudinal prevalence ratios), Outcome I Diarrhoea: all ages.

Review: Interventions to improve water quality for preventing diarrhoea

Comparison: 3 Water quality intervention versus control: point and type of intervention (longitudinal prevalence ratios)

Outcome: I Diarrhoea: all ages

$\begin{array}{llc}\text { Study or subgroup } & \log \text { [Long. prev. ratio] } & \text { Long. prev. } \\ \text { ratio } & \text { Woight }\end{array}$

(SE) IV,Random,95\% Cl

IV,Random,95\% Cl

I Source or household treatment

Austin 1993-i

$0.0513(0.7245)$

Austin 1993-ii

$0.01(0.8544)$

Chiller 2004

$-0.478(0.1426)$

Crump 2004-i

$-0.2614(0.1072)$

Crump 2004-ii

$-0.1863(0.1101)$

Doocy 2004

$-2.1203(0.0408)$

Kirchhoff 1985

$0.0677(0.0993)$

Luby 2004b-i

$-0.7985(0.3123)$

Luby 2004b-ii

$-0.7985(0.3062)$

Luby 2004b-iii

$-1.0217(0.3465)$

IVRandom, $95 \%$

$6.6 \%$

$5.8 \%$

$10.0 \%$

$10.0 \%$

$10.0 \%$

$10.1 \%$

$10.1 \%$

$9.2 \%$

$9.3 \%$

$9.1 \%$

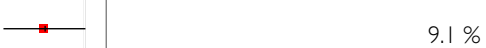

$\begin{array}{lllllll}0.1 & 0.2 & 0.5 & 1 & 2 & 5 & 10\end{array}$

Favours intervention Favours control

(Continued...) 


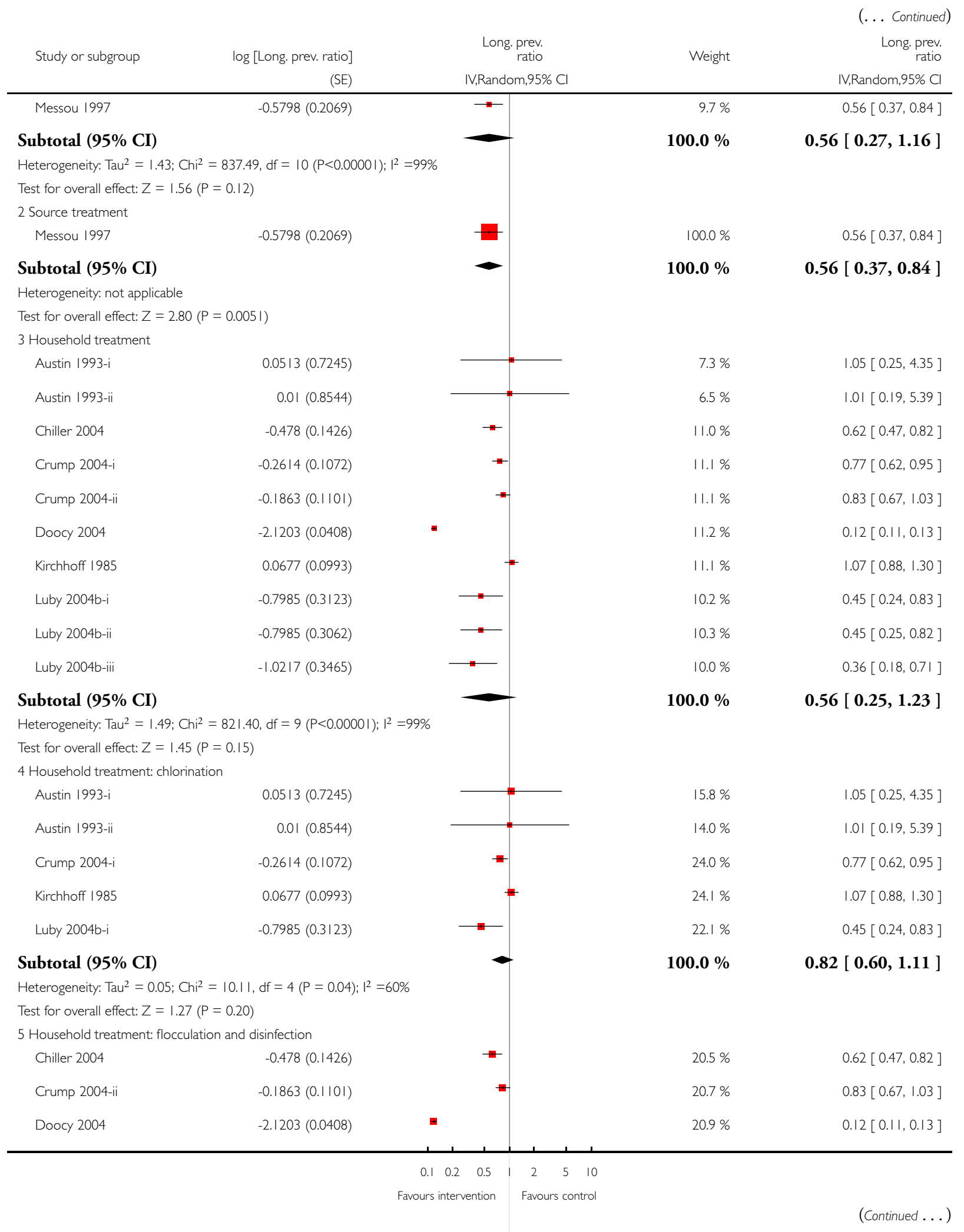

Interventions to improve water quality for preventing diarrhoea (Review) 


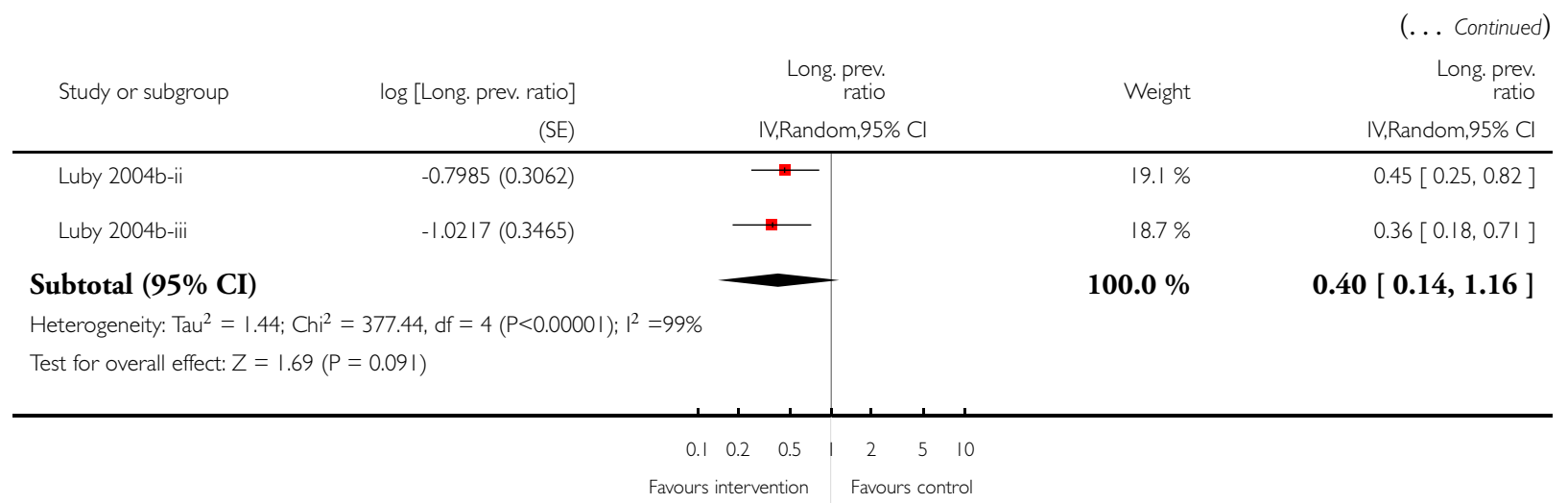

Analysis 3.2. Comparison 3 Water quality intervention versus control: point and type of intervention (longitudinal prevalence ratios), Outcome 2 Diarrhoea: children $<5$ years.

Review: Interventions to improve water quality for preventing diarrhoea

Comparison: 3 Water quality intervention versus control: point and type of intervention (longitudinal prevalence ratios)

Outcome: 2 Diarrhoea: children $<5$ years

$\begin{array}{lrr}\text { Study or subgroup } & \log [\text { Long. prev. ratio] } & \text { Long. prev. } \\ \text { ratio } & \text { Weight }\end{array}$

(SE) IV,Random,95\% Cl

IV,Random,95\% Cl

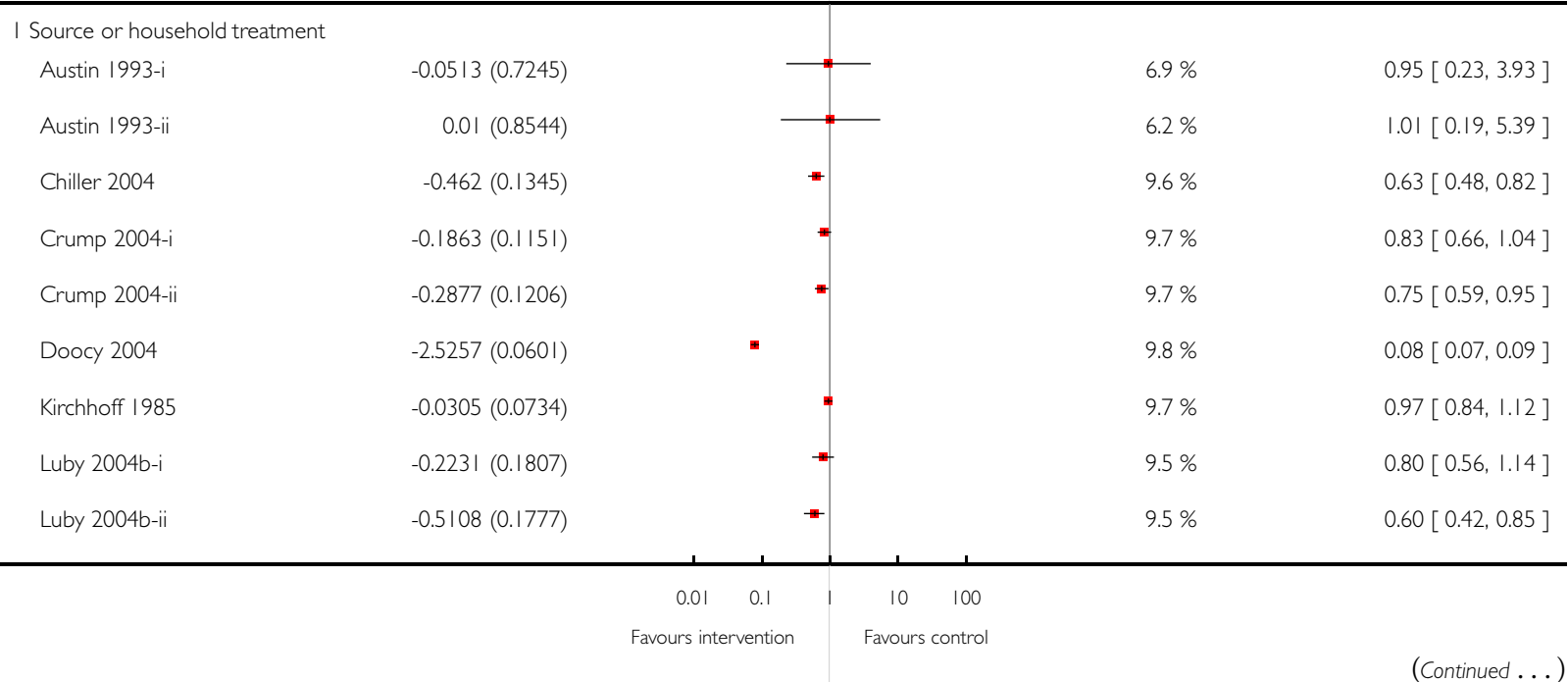

Interventions to improve water quality for preventing diarrhoea (Review)

Copyright @ 2009 The Cochrane Collaboration. Published by John Wiley \& Sons, Ltd. 


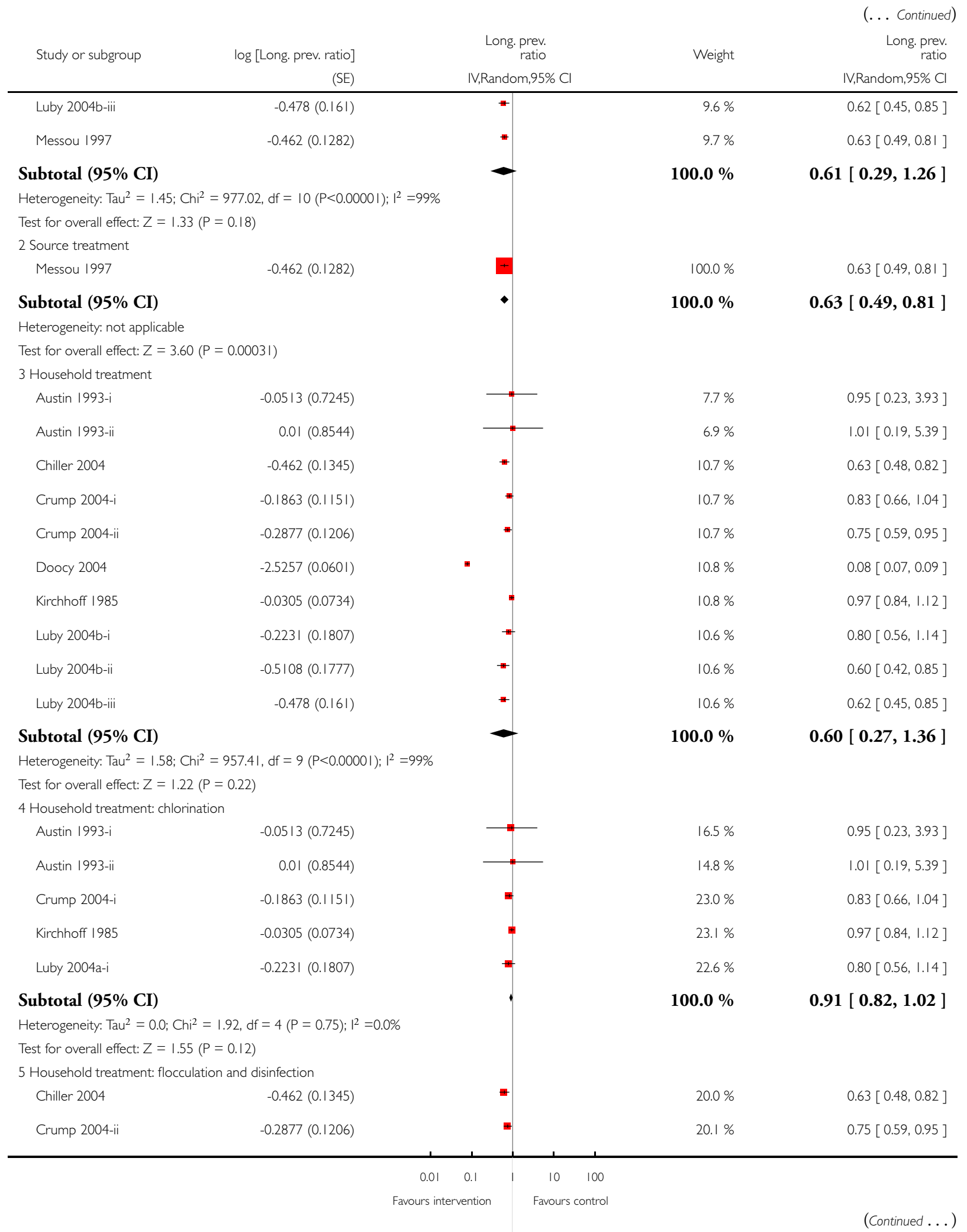

Interventions to improve water quality for preventing diarrhoea (Review) 


\begin{tabular}{|c|c|}
\hline \multicolumn{2}{|c|}{ Subtotal (95\% CI) } \\
\hline \multicolumn{2}{|c|}{ Heterogeneity: $\mathrm{Tau}^{2}=0.03 ; \mathrm{Chi}^{2}=23.98, \mathrm{df}=8(\mathrm{P}=0$} \\
\hline \multicolumn{2}{|c|}{ Test for overall effect: $Z=5.12(P<0.0000 I)$} \\
\hline \multicolumn{2}{|c|}{2 Household treatment } \\
\hline Clasen 2004b & $-0.755(0.3427)$ \\
\hline Clasen $2004 c$ & $-1.204(0.2291)$ \\
\hline Conroy 1996 & $-0.4155(0.1409)$ \\
\hline Conroy 1999 & $-0.37 \mid I(0.0425)$ \\
\hline Quick 2002 & $-0.6539(0.2799)$ \\
\hline Reller 2003-i & $-0.2357(0.1151)$ \\
\hline Reller 2003-ii & $-0.301 \mid(0.11|1|)$ \\
\hline Reller 2003-iii & $-0.0305(0.1335)$ \\
\hline Reller 2003-iv & $-0.3011(0.1221)$ \\
\hline
\end{tabular}

IV,Random,95\% Cl

\section{Subtotal $(\mathbf{9 5 \%} \mathrm{CI})$}

Heterogeneity: $\mathrm{Tau}^{2}=0.03 ; \mathrm{Chi}^{2}=23.98, \mathrm{df}=8(\mathrm{P}=0.002) ; \mathrm{I}^{2}=67 \%$ Test for overall effect: $Z=5.12(P<0.0000 \mathrm{I})$

3 Household treatment: chlorination

$\begin{array}{ll}\text { Quick } 2002 & -0.6539(0.2799) \\ \text { Reller 2003-ii } & -0.3011(0.1111) \\ \text { Reller 2003-iii } & -0.0305(0.1335)\end{array}$

Subtotal $(95 \% \mathrm{CI})$

Heterogeneity: $\mathrm{Tau}^{2}=0.03 ; \mathrm{Chi}^{2}=4.94, \mathrm{df}=2(\mathrm{P}=0.08) ; \mathrm{I}^{2}=59 \%$

Test for overall effect: $Z=1.82(P=0.069)$

4 Household treatment: filtration

$\begin{array}{lc}\text { Clasen 2004b } & -0.755(0.3427) \\ \text { Clasen 2004c } & -1.204(0.2291)\end{array}$

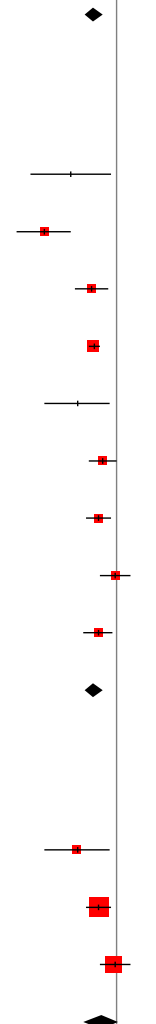

$100.0 \%$

$0.68[0.59,0.79]$

$002) ;\left.\right|^{2}=67 \%$

$3.3 \%$

$0.47[0.24,0.92]$

$6.2 \%$

$0.30[0.19,0.47]$

$11.4 \%$

$0.66[0.50,0.87]$

$21.4 \%$

$0.69[0.63,0.75]$

$4.6 \%$

$0.52[0.30,0.90]$

$13.8 \%$

$0.79[0.63,0.99]$

$14.2 \%$

$0.74[0.60,0.92]$

$12.1 \%$

$0.97[0.75,1.26]$

$13.1 \%$

$0.74[0.58,0.94]$

$100.0 \%$

$0.68[0.59,0.79]$

$14.8 \%$

$0.52[0.30,0.90]$

$46.0 \%$

$0.74[0.60,0.92]$

$39.2 \%$

$0.97[0.75,1.26]$

$100.0 \%$

$0.77[0.58,1.02]$

Subtotal $(\mathbf{9 5 \%} \mathrm{CI})$

Heterogeneity: Tau $^{2}=0.02 ; \mathrm{Chi}^{2}=1.19, \mathrm{df}=\mathrm{I}(\mathrm{P}=0.28) ; \mathrm{I}^{2}=16 \%$ Test for overall effect: $Z=4.95(P<0.0000 \mathrm{I})$

5 Household treatment: solar disinfection

$$
\begin{array}{ll}
\text { Conroy } 1996 & -0.4155(0.1409) \\
\text { Conroy } 1999 & -0.3711(0.0425)
\end{array}
$$

\section{Subtotal $(95 \% \mathrm{CI})$}

Heterogeneity: Tau $^{2}=0.0 ; \mathrm{Chi}^{2}=0.09, \mathrm{df}=\mathrm{I}(\mathrm{P}=0.76) ; \mathrm{I}^{2}=0.0 \%$ Test for overall effect: $Z=9.21(P<0.00001)$

6 Household treatment: flocculation and disinfection
Reller 2003-i
$-0.2357(0.1151)$

$34.4 \%$

$65.6 \%$

$100.0 \%$

$34.9 \%$

$65.1 \%$

$100.0 \%$

$$
\begin{aligned}
& 0.47[0.24,0.92] \\
& 0.30[0.19,0.47]
\end{aligned}
$$

$0.35[0.23,0.53]$

$0.66[0.50,0.87]$

$0.69[0.63,0.75]$

$0.69[0.63,0.74]$

$51.3 \%$ 


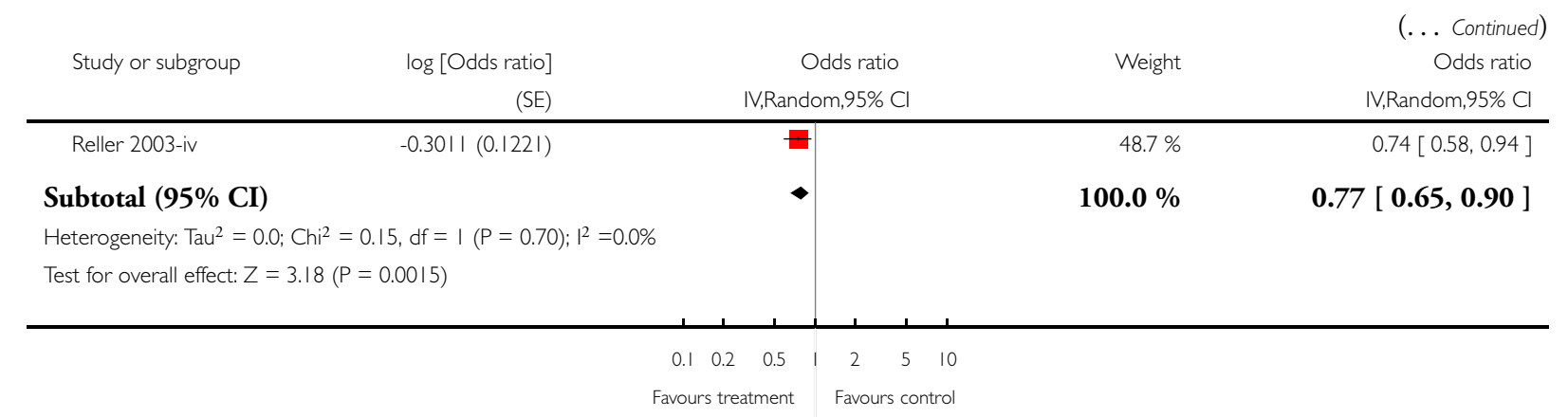

Analysis 4.2. Comparison 4 Water quality intervention versus control: point and type of intervention (odds ratios), Outcome 2 Diarrhoea: children $<5$ years.

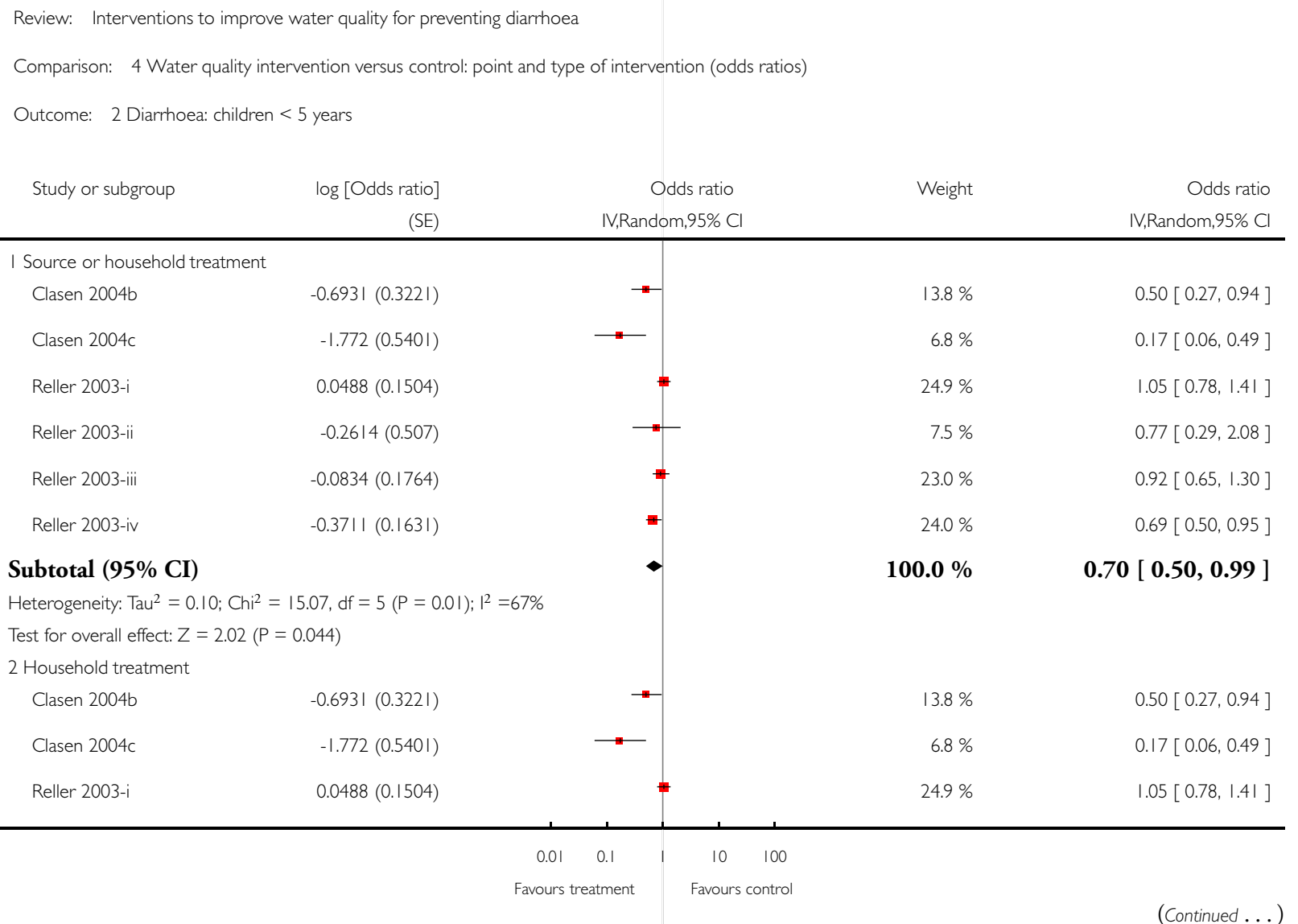




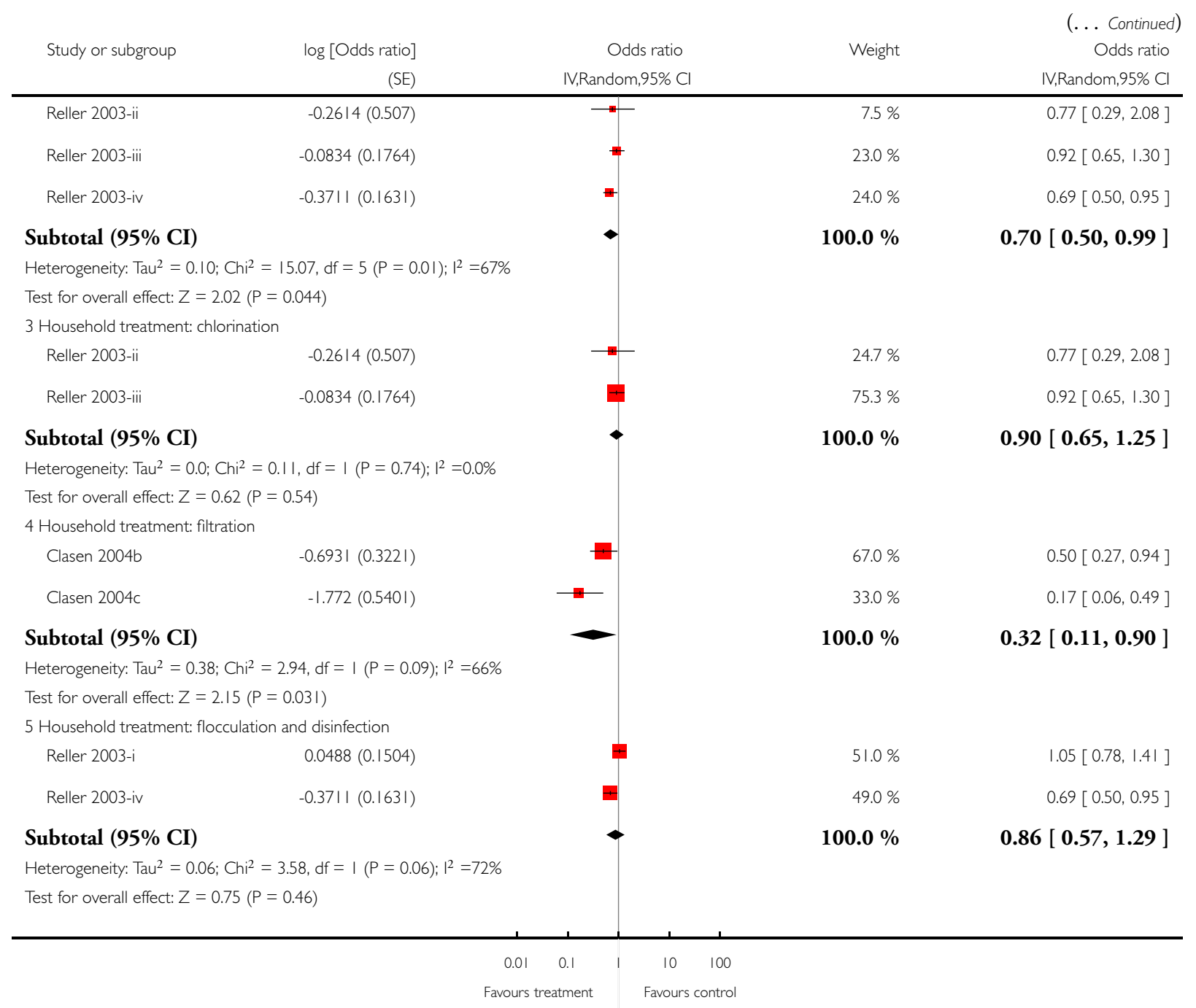


Analysis 5.I. Comparison 5 Water quality intervention versus control: point and type of intervention (means ratios), Outcome I Diarrhoea: all ages.

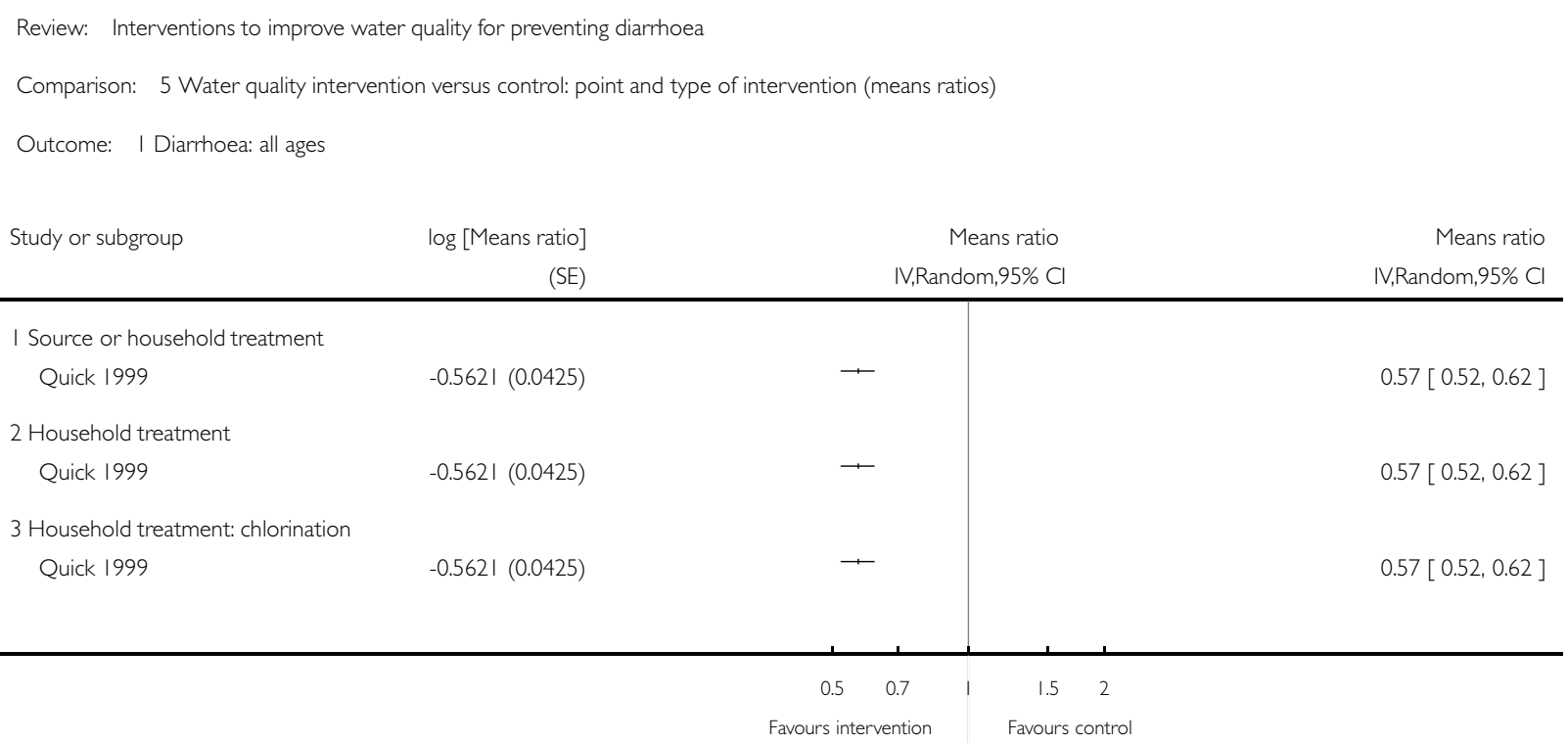

Analysis 5.2. Comparison 5 Water quality intervention versus control: point and type of intervention (means ratios), Outcome 2 Diarrhoea: children $<5$ years.

Review: Interventions to improve water quality for preventing diarrhoea

Comparison: 5 Water quality intervention versus control: point and type of intervention (means ratios)

Outcome: 2 Diarrhoea: children $<5$ years

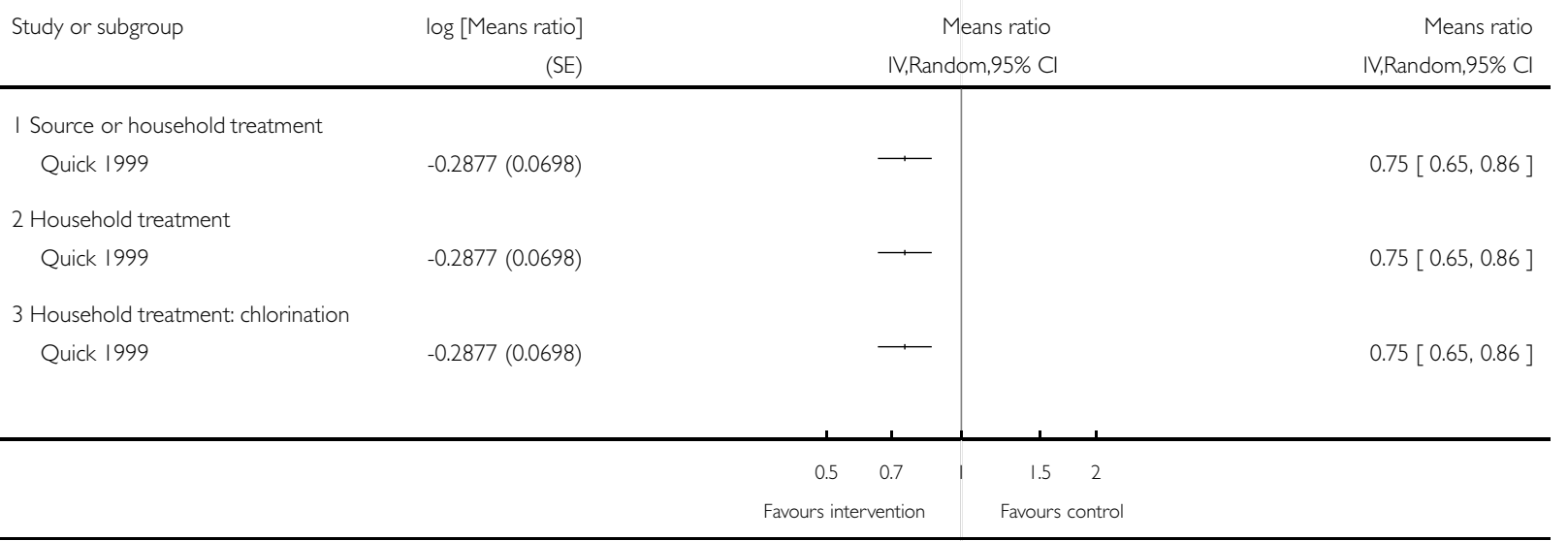

Interventions to improve water quality for preventing diarrhoea (Review)

Copyright @ 2009 The Cochrane Collaboration. Published by John Wiley \& Sons, Ltd. 
Analysis 6.I. Comparison 6 Water quantity intervention versus control: by compliance with intervention (risk ratios), Outcome I Diarrhoea: all ages.

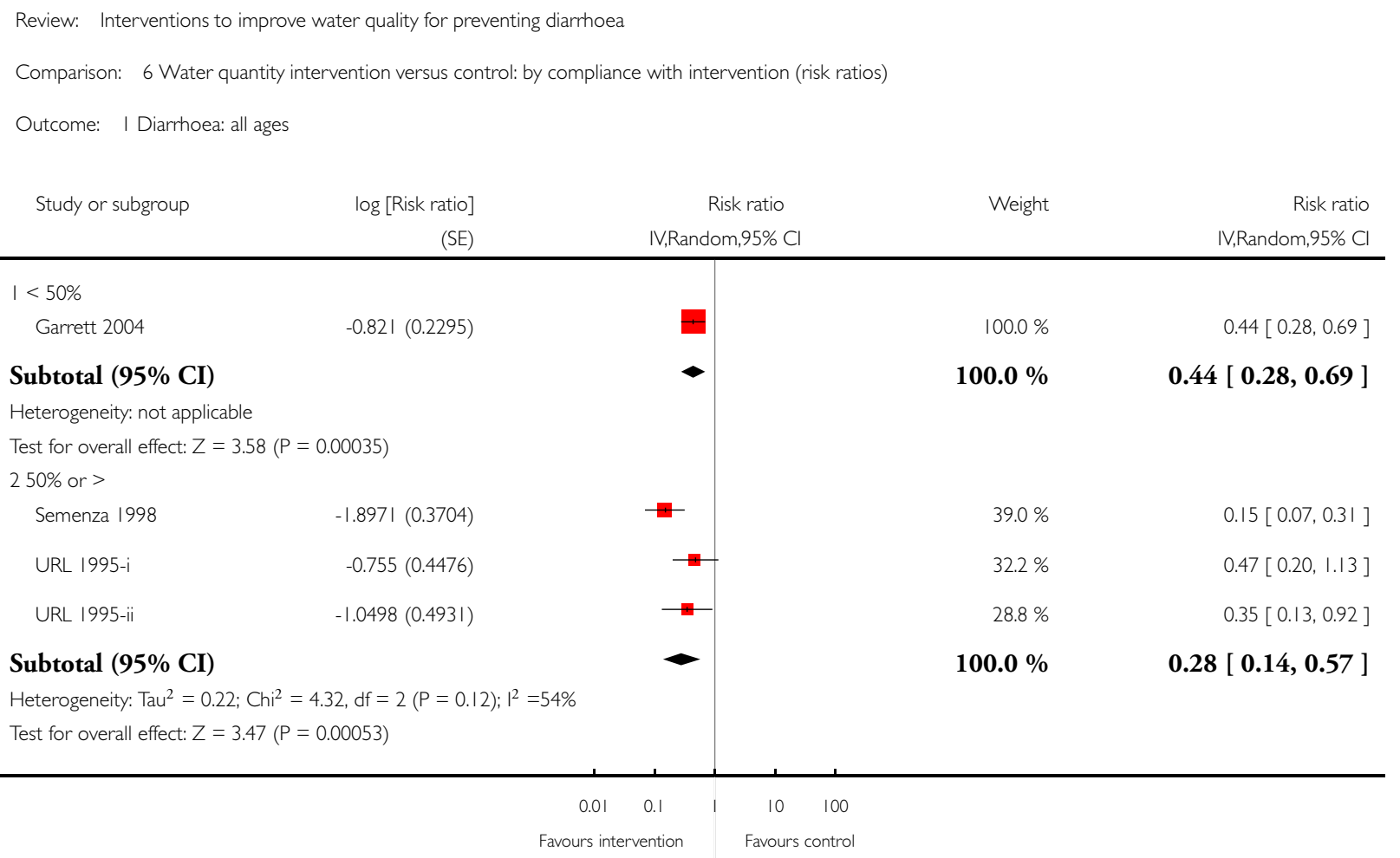


Analysis 7.I. Comparison 7 Water quality intervention versus control: by compliance with intervention (odds ratios), Outcome I Diarrhoea: all ages.

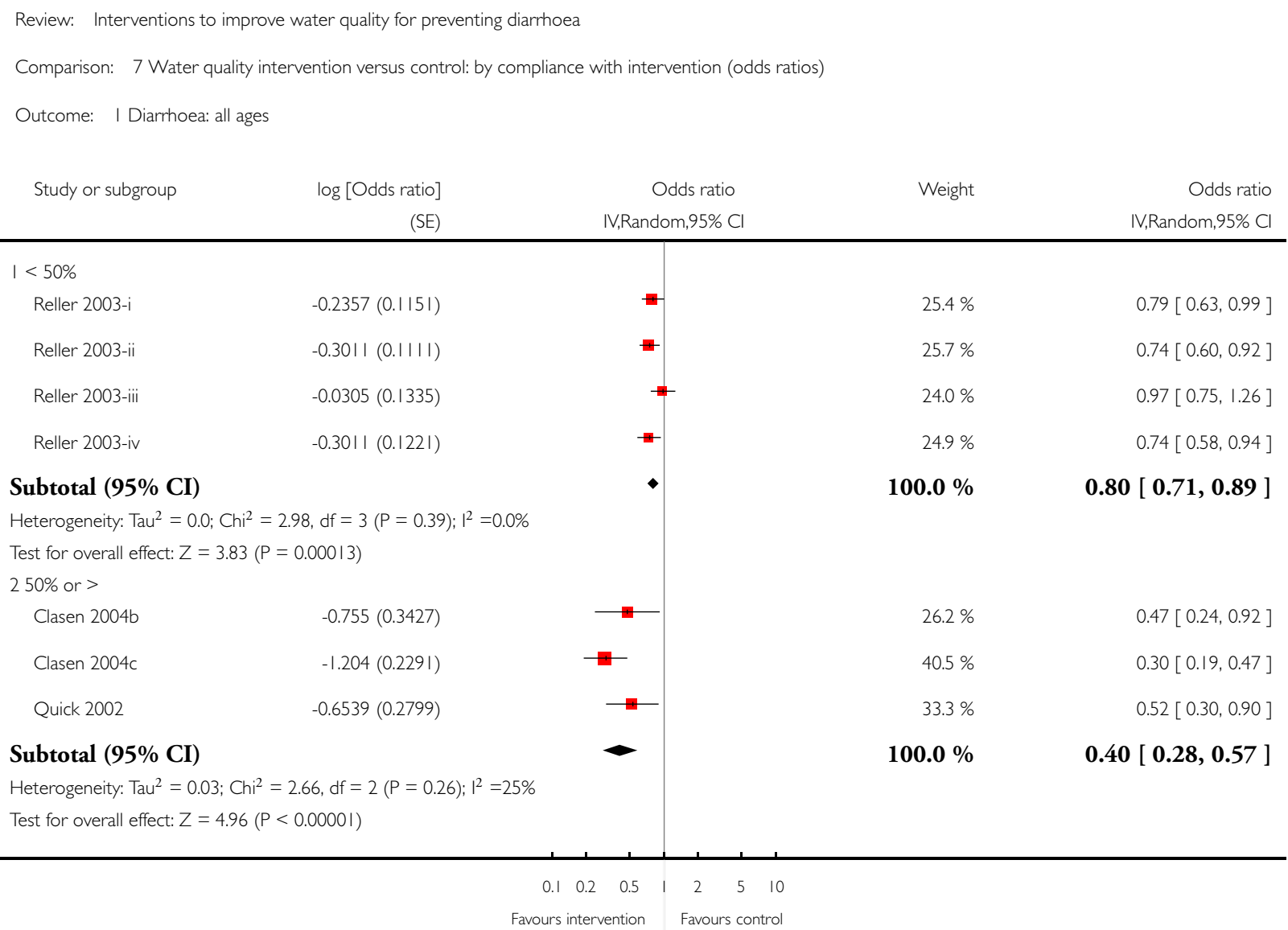


Analysis 8.I. Comparison 8 Water quality intervention versus control: by ambient water quality (rate ratios), Outcome I Diarrhoea: all ages.

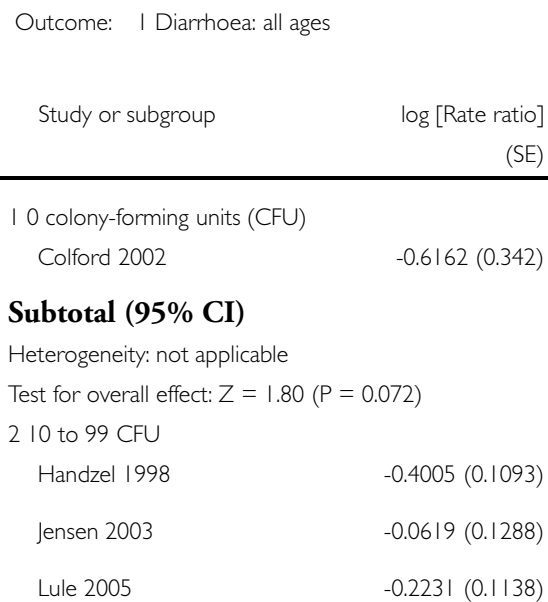

Subtotal (95\% CI)

Heterogeneity: not applicable

Test for overall effect: $Z=1.80(P=0.072)$

210 to 99 CFU

$\begin{array}{ll}\text { Handzel } 1998 & -0.4005(0.1093) \\ \text { Jensen } 2003 & -0.0619(0.1288) \\ \text { Lule } 2005 & -0.2231(0.1138)\end{array}$

\begin{tabular}{|c|c|c|}
\hline 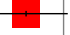 & $100.0 \%$ & $0.54[0.28,1.06]$ \\
\hline & $100.0 \%$ & $0.54[0.28,1.06]$ \\
\hline+7 & $35.6 \%$ & $0.67[0.54,0.83]$ \\
\hline & $30.2 \%$ & $0.94[0.73,1.21]$ \\
\hline+ & $34.2 \%$ & $0.80[0.64,1.00]$ \\
\hline
\end{tabular}

Subtotal (95\% CI)

Heterogeneity: Tau $^{2}=0.01 ; \mathrm{Chi}^{2}=4.08, \mathrm{df}=2(\mathrm{P}=0.13) ; 1^{2}=51 \%$

Test for overall effect: $Z=2.46(P=0.014)$

$\begin{array}{lllllll}0.1 & 0.2 & 0.5 & \mid & 2 & 5 & 10\end{array}$

Favours intervention Favours control 
Analysis 9.1. Comparison 9 Water quality intervention versus control: by ambient water quality (risk ratios), Outcome I Diarrhoea: all ages.

Review: Interventions to improve water quality for preventing diarrhoea

Comparison: 9 Water quality intervention versus control: by ambient water quality (risk ratios)

Outcome: I Diarrhoea: all ages

Study or subgroup $\quad \log$ [Risk ratio] Risk ratio Reight ratio

(SE) IV,Random,95\% Cl

IV,Random,95\% Cl

I 10 to 99 colony-forming units (CFU)

Roberts 2001

$-0.2357(0.1353)$

Semenza 1998

$-1.897 \mid(0.3704)$

$0.79[0.61,1.03]$

$54.4 \%$

$0.15[0.07,0.31]$

Subtotal (95\% CI)

Heterogeneity: $\mathrm{Tau}^{2}=1.30 ; \mathrm{Chi}^{2}=17.75, \mathrm{df}=\mathrm{I}(\mathrm{P}=0.00003) ; \mathrm{I}^{2}=94 \%$

Test for overall effect: $Z=1.24(P=0.21)$

$2>99 \mathrm{CFU}$
URL 1995-i
$-0.755(0.4476)$
URL 1995-ii
$-1.0498(0.4931)$

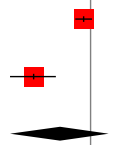

$45.6 \%$

$100.0 \%$

$0.36[0.07,1.81]$

Subtotal (95\% CI)

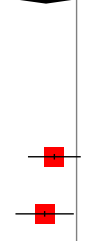

$51.3 \%$

$0.47[0.20,1.13]$

$48.7 \%$

$0.35[0.13,0.92]$

Heterogeneity: Tau $^{2}=0.0 ; \mathrm{Chi}^{2}=0.20, \mathrm{df}=\mathrm{I}(\mathrm{P}=0.66) ; \mathrm{I}^{2}=0.0 \%$

Test for overall effect: $Z=2.68(P=0.0074)$

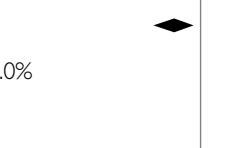

$100.0 \%$

$0.41[0.21,0.79$ ] 
Analysis 10.1. Comparison 10 Water quality intervention versus control: by ambient water quality (longitudinal prevalence ratios), Outcome I Diarrhoea: all ages.

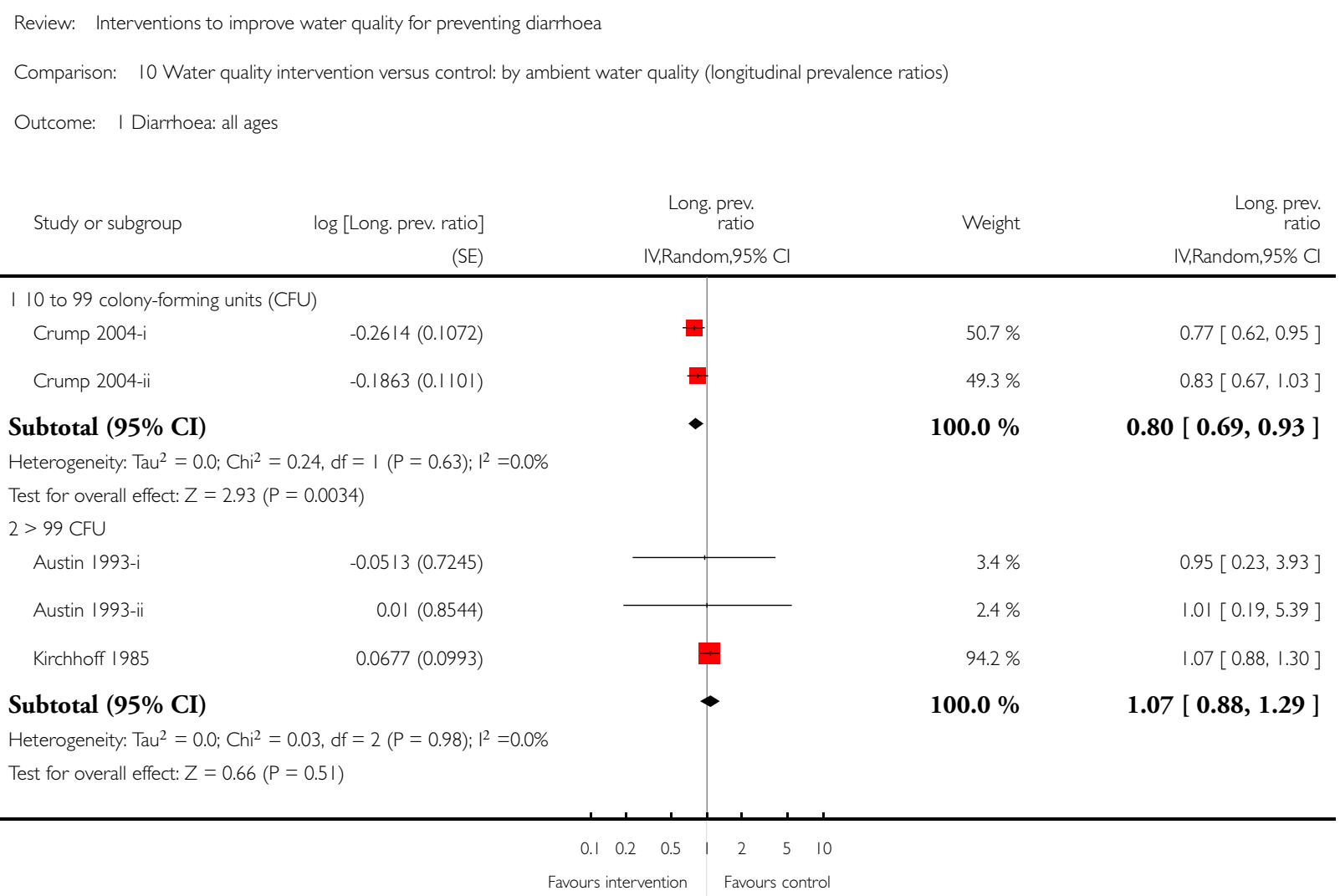


Analysis I I.I. Comparison I I Water quality intervention versus control: by ambient water quality (odds ratios), Outcome I Diarrhoea: all ages.

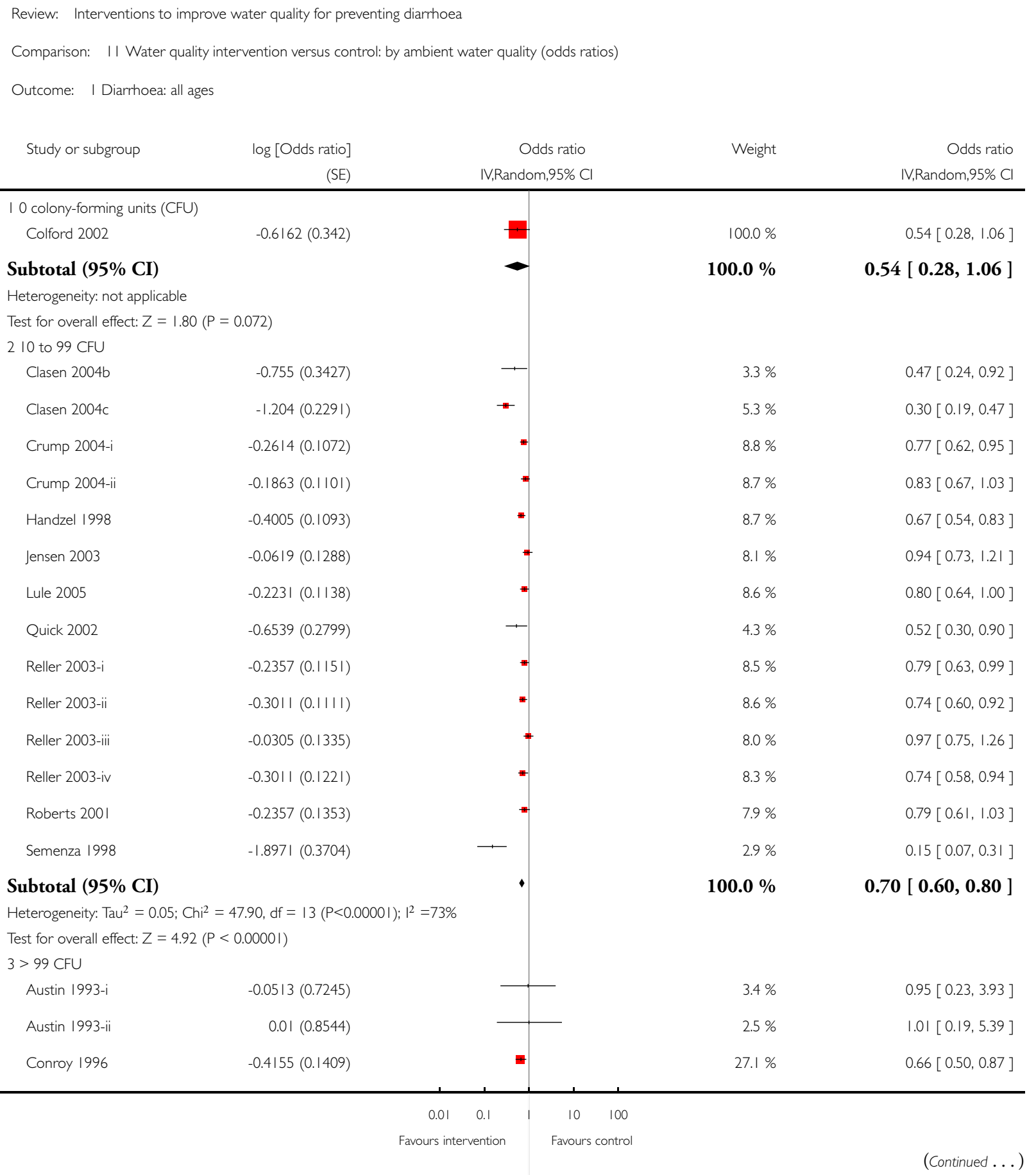




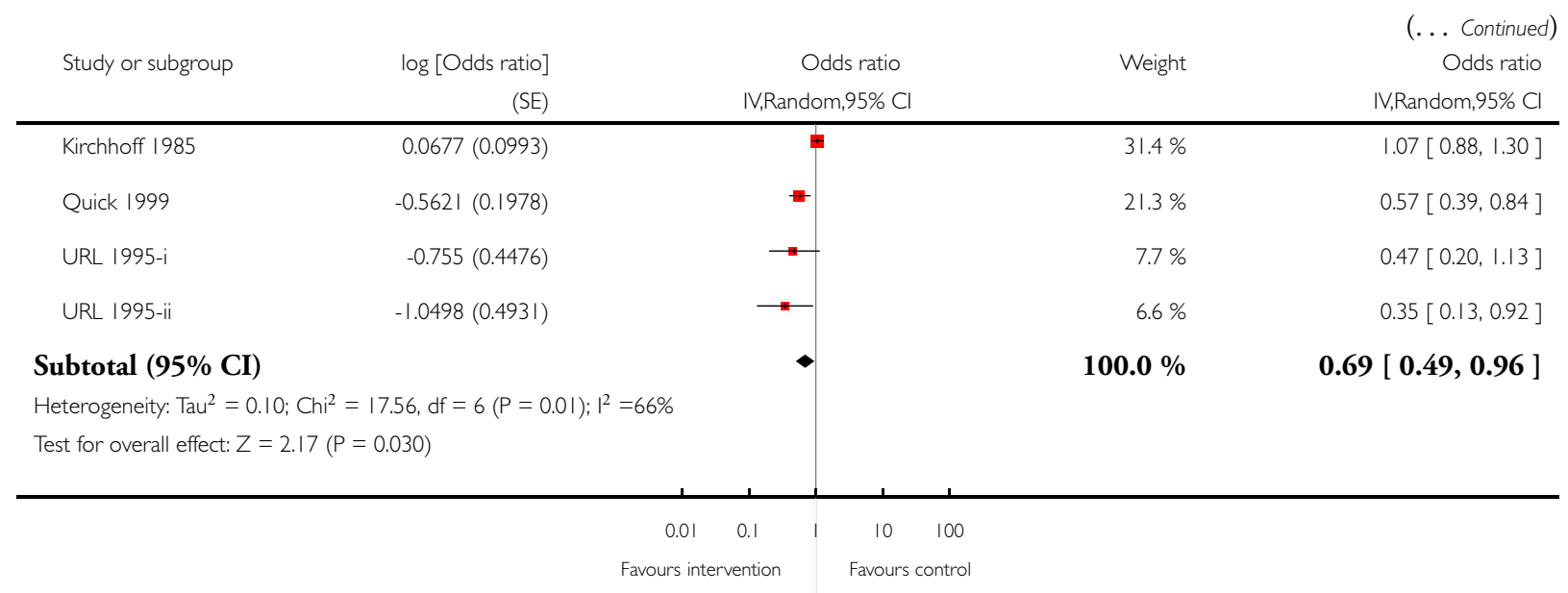

Analysis 12.1. Comparison 12 Water quality intervention versus control: by sufficiency of water quantity (long. prev. ratios), Outcome I Diarrhoea: all ages.

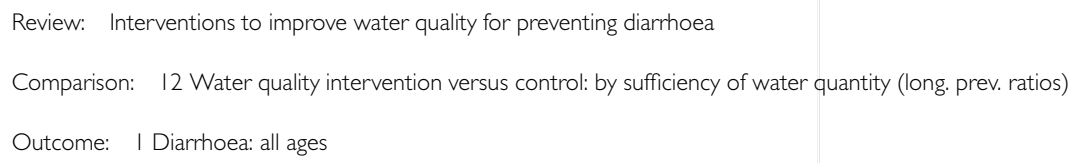




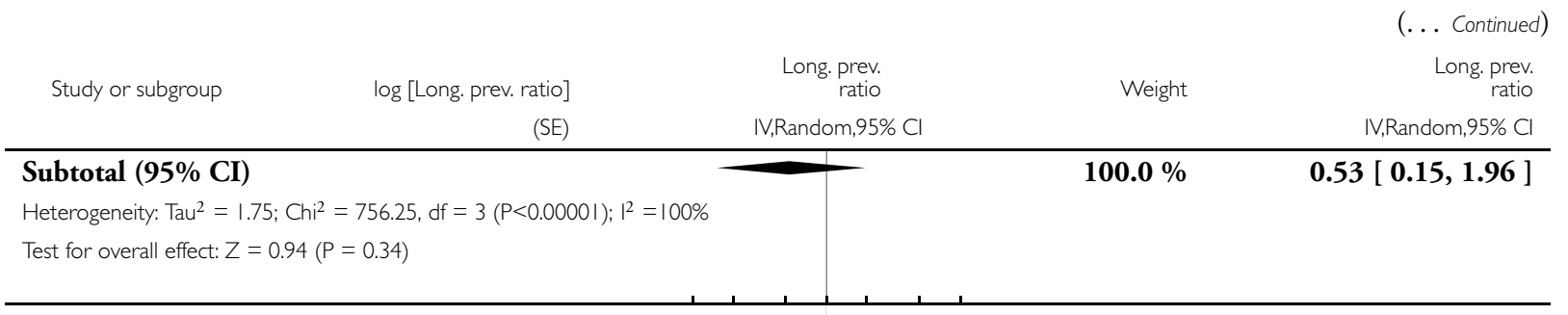

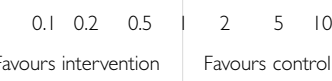

\section{Analysis 13.I. Comparison I3 Water quality intervention versus control: by water supply level (rate ratios), Outcome I Diarrhoea: all ages.}

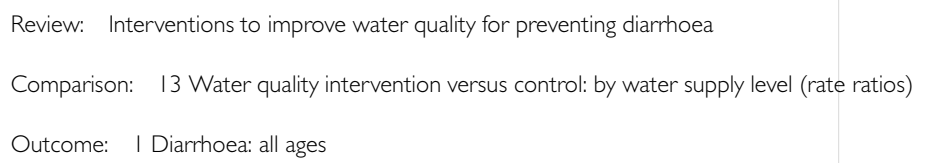

\begin{tabular}{ll}
\hline I Improved water supply & \\
Colford 2002 & $-0.6162(0.342)$ \\
Handzel 1998 & $-0.4005(0.1093)$ \\
Jensen 2003 & $-0.0619(0.1288)$
\end{tabular}

Subtotal $(95 \% \mathrm{CI})$

Heterogeneity: $\operatorname{Tau}^{2}=0.04 ; \mathrm{Chi}^{2}=5.05, \mathrm{df}=2(\mathrm{P}=0.08) ; \mathrm{I}^{2}=60 \%$

Test for overall effect: $Z=1.98(P=0.048)$

2 Unimproved water supply

$\begin{array}{lr}\text { Alam } 1989 & -0.1863(0.0795) \\ \text { Aziz 1990 } & -0.2877(0.0329) \\ \text { Gasana 2002 } & 0(0.0578) \\ \text { Luby 2004a-i } & -0.5108(0.1717) \\ \text { Luby 2004a-ii } & -1.204(0.2806) \\ \text { Lule 2005 } & -0.2231(0.1138)\end{array}$

$13.0 \%$
$75.8 \%$
$+71.2 \%$

$100.0 \%$

$0.75[0.56,1.00]$

\begin{tabular}{ll}
$19.8 \%$ & $0.83[0.71,0.97]$ \\
$23.2 \%$ & $0.75[0.70,0.80]$ \\
$21.6 \%$ & $1.00[0.89,1.12]$ \\
$12.0 \%$ & $0.60[0.43,0.84]$ \\
$6.6 \%$ & $0.30[0.17,0.52]$ \\
$16.7 \%$ & $0.80[0.64,1.00]$ \\
\hline & \\
& (Continued ...)
\end{tabular}




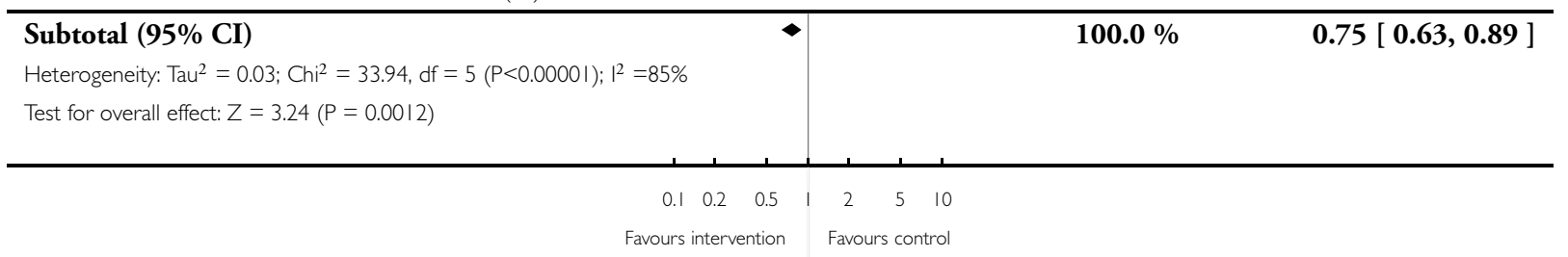

Analysis I4.I. Comparison I4 Water quality intervention versus control: by water supply level (risk ratios), Outcome I Diarrhoea: all ages.

Review: Interventions to improve water quality for preventing diarrhoea

Comparison: 14 Water quality intervention versus control: by water supply level (risk ratios)

Outcome: I Diarrhoea: all ages

Study or subgroup log [Risk ratio] Risk ratio Weight

IV,Random,95\% Cl

IV,Random,95\% Cl

$\begin{array}{ll}\text { I Improved water supply } & \\ \text { Roberts 200 I } & -0.2357(0.1353) \\ \text { URL 1995-i } & -0.755(0.4476) \\ \text { URL 1995-ii } & -1.0498(0.493 \text { I) }\end{array}$

Subtotal $(95 \% \mathrm{CI})$

Heterogeneity: $\mathrm{Tau}^{2}=0.09 ; \mathrm{Chi}^{2}=3.52, \mathrm{df}=2(\mathrm{P}=0.17) ; \mathrm{I}^{2}=43 \%$

Test for overall effect: $Z=1.99(P=0.046)$

2 Unimproved water supply

$\begin{array}{lr}\text { Mahfouz I995 } & -0.5978(0.305) \\ \text { Semenza |998 } & -1.897 \mid(0.3704) \\ \text { Xiao 1997 } & -0.7985(0.0222)\end{array}$

Subtotal $(95 \%$ CI $)$

Heterogeneity: Tau $^{2}=0.20 ; \mathrm{Chi}^{2}=9.2 \mathrm{I}, \mathrm{df}=2(\mathrm{P}=0.0 \mathrm{I}) ; \mathrm{I}^{2}=78 \%$

Test for overall effect: $Z=3.45(P=0.00057)$

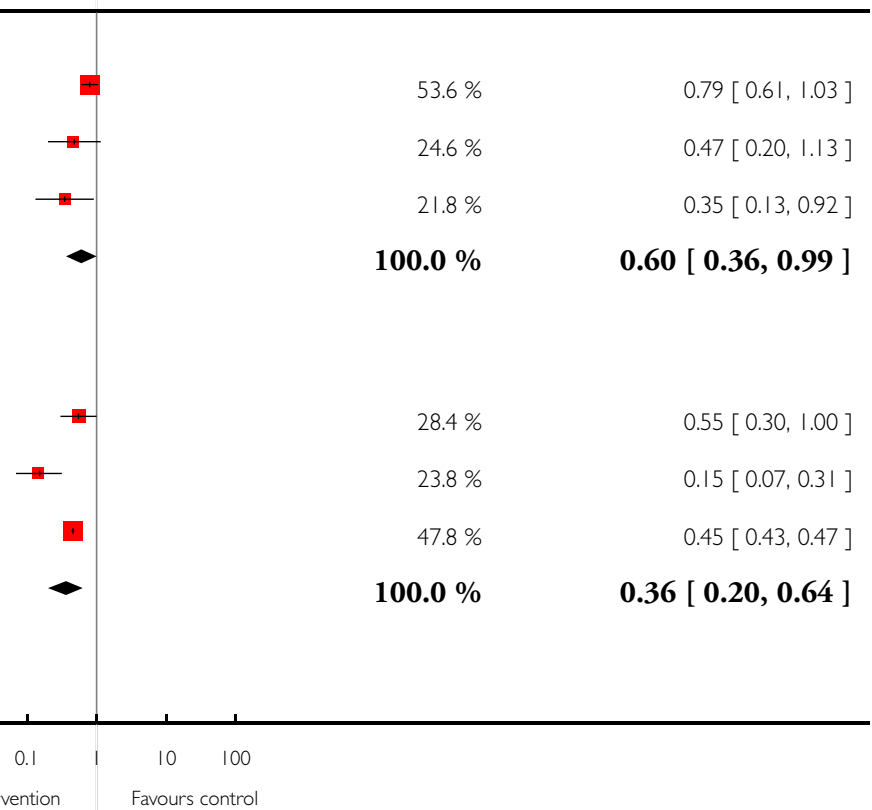


Analysis 15.I. Comparison I5 Water quality intervention versus control: by water supply level (longitudinal prevalence ratios), Outcome I Diarrhoea: all ages.

Review: Interventions to improve water quality for preventing diarrhoea

Comparison: 15 Water quality intervention versus control: by water supply level (longitudinal prevalence ratios)

Outcome: I Diarrhoea: all ages

Study or subgroup $\quad \log$ [Long. prev. ratio]

(SE)

\begin{tabular}{ll}
\hline $\begin{array}{l}\text { I Improved water supply } \\
\text { du Preez 2004 }\end{array}$ & $-1.5606(0.544$ I) \\
Luby 2004b-i & $-0.7985(0.3123)$ \\
Luby 2004b-ii & $-0.7985(0.3062)$ \\
Luby 2004b-iii & $-1.0217(0.3465)$
\end{tabular}

Subtotal $(\mathbf{9 5 \%}$ CI)

Heterogeneity: Tau $^{2}=0.0 ; \mathrm{Chi}^{2}=1.77, \mathrm{df}=3(\mathrm{P}=0.62) ; \mathrm{I}^{2}=0.0 \%$

Test for overall effect: $Z=5.34(P<0.0000$ I $)$

2 Unimproved water supply

$\begin{array}{lr}\text { Austin 1993-i } & -0.0513(0.7245) \\ \text { Austin 1993-ii } & 0.01(0.8544) \\ \text { Crump 2004-i } & -0.2614(0.1072) \\ \text { Crump 2004-ii } & -0.1863(0.1101) \\ \text { Doocy 2004 } & -2.1203(0.0408) \\ \text { Kirchhoff 1985 } & 0.0677(0.0993) \\ \text { Messou 1997 } & -0.5798(0.2069)\end{array}$

Messou 1997

Subtotal $(\mathbf{9 5 \%} \mathrm{CI})$

Heterogeneity: $\mathrm{Tau}^{2}=1.66 ; \mathrm{Chi}^{2}=782.23, \mathrm{df}=6(\mathrm{P}<0.0000 \mathrm{I}) ; \mathrm{I}^{2}=99 \%$

Test for overall effect: $Z=0.95(P=0.34)$

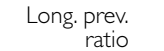

IV,Random,95\% Cl

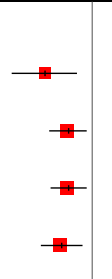

Weight

Long. prev.

IV,Random,95\% Cl

$\begin{array}{ll}23.0 \% & 0.21[0.07,0.61] \\ 25.8 \% & 0.45[0.24,0.83] \\ 25.8 \% & 0.45[0.25,0.82] \\ 25.4 \% & 0.36[0.18,0.71]\end{array}$

$100.0 \%$

$0.39[0.28,0.55]$

$11.7 \%$

$0.95[0.23,3.93]$

$10.6 \%$

$1.01[0.19,5.39]$

$15.6 \%$

$0.77[0.62,0.95]$

$15.6 \%$

$0.83[0.67,1.03]$

$15.7 \%$

$0.12[0.11,0.13]$

$15.6 \%$

$1.07[0.88,1.30]$

$15.3 \%$

$0.56[0.37,0.84]$

$100.0 \%$

$0.62[0.23,1.67]$

0.01

$10 \quad 100$

Favours intervention Favours control 
Analysis 16.1. Comparison 16 Water quality intervention versus control: by water supply level (odds ratios), Outcome I Diarrhoea: all ages.

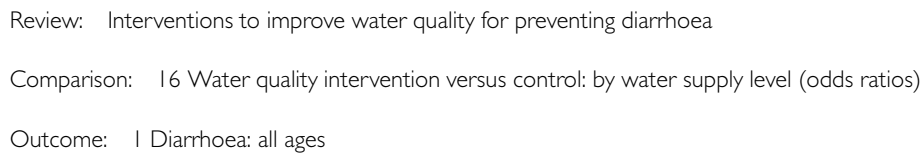

I Improved water supply

$$
\text { Clasen 2004b }
$$

$-0.755(0.3427)$

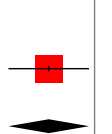

Subtotal (95\% CI)

Heterogeneity: not applicable

Test for overall effect: $Z=2.20(P=0.028)$

2 Unimproved water supply

Clasen 2004c

$-1.204(0.229 \mid)$

Conroy 1996

$-0.4155(0.1409)$

Conroy 1999

-0.37 II (0.0425)

Quick 2002

$-0.65(0.28)$

Reller 2003-i

$-0.2357(0.1|5|)$

Reller 2003-ii

$-0.3011(0.1111)$

Reller 2003-iii

$-0.0305(0.1335)$

Reller 2003-iv

$-0.3011(0.1221)$

Subtotal (95\% CI)

Heterogeneity: $\mathrm{Tau}^{2}=0.03 ; \mathrm{Chi}^{2}=22.57, \mathrm{df}=7(\mathrm{P}=0.002) ;\left.\right|^{2}=69 \%$

Test for overall effect: $Z=4.83(P<0.00001)$

$00.0 \%$

$100.0 \%$

$7.3 \%$

$12.3 \%$

$19.7 \%$

$5.5 \%$

$14.2 \%$

$14.5 \%$

$12.8 \%$

$13.7 \%$

$100.0 \%$
$0.47[0.24,0.92]$

$0.47[0.24,0.92]$

$0.30[0.19,0.47]$

$0.66[0.50,0.87]$

$0.69[0.63,0.75]$

$0.52[0.30,0.90]$

$0.79[0.63,0.99]$

$0.74[0.60,0.92]$

$0.97[0.75,1.26]$

$0.74[0.58,0.94]$

$0.69[0.59,0.80]$

$\begin{array}{lllllll}0.1 & 0.2 & 0.5 & 1 & 2 & 5 & 10\end{array}$

Favours intervention Favours control 
Analysis 17.I. Comparison 17 Water quality intervention versus control: by sanitation level (rate ratios), Outcome I Diarrhoea: all ages.

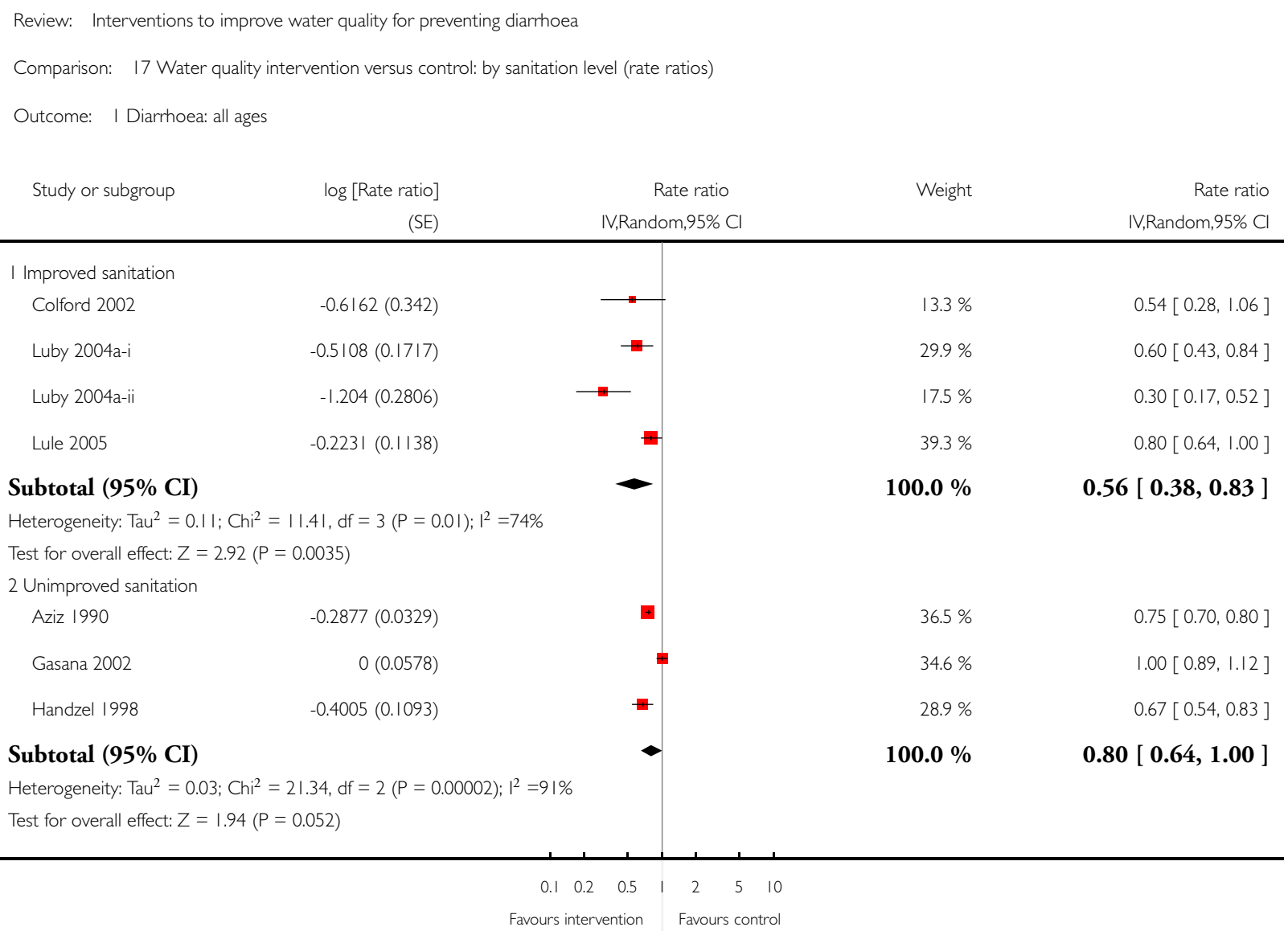


Analysis 18.I. Comparison 18 Water quality intervention versus control: by sanitation level (risk ratios), Outcome I Diarrhoea: all ages.

Review: Interventions to improve water quality for preventing diarrhoea

Comparison: 18 Water quality intervention versus control: by sanitation level (risk ratios)

Outcome: I Diarrhoea: all ages

Study or subgroup $\quad \log$ [Risk ratio] Risk ratio Risk ratio IV,Random,95\% Cl IV,Random,95\% Cl

I Improved sanitation

Mahfouz 1995

$-0.5978(0.305)$

URL 1995-i

$-0.755(0.4476)$

URL 1995-ii

$-1.0498(0.4931)$

Subtotal $(95 \%$ CI)

Heterogeneity: $\mathrm{Tau}^{2}=0.0 ; \mathrm{Chi}^{2}=0.6 \mathrm{l}, \mathrm{df}=2(\mathrm{P}=0.74) ; \mathrm{I}^{2}=0.0 \%$

Test for overall effect: $Z=3.26(P=0.0011)$

2 Unimproved sanitation

$$
\text { Garrett } 2004 \quad-0.821(0.2295)
$$

Subtotal (95\% CI)

Heterogeneity: not applicable

Test for overall effect: $Z=3.58(P=0.00035)$

\begin{tabular}{ccc}
$25.1 \%$ & $0.55[0.30,1.00]$ \\
\hdashline$-10.7 \%$ & $0.47[0.20,1.13]$ \\
\hline$-10.13,0.92]$
\end{tabular}

$\begin{array}{rrrrrrrr}0.1 & 0.2 & 0.5 & 1 & 2 & 5 & 10 & 10 \\ \text { Favours intervention } & \text { Favours control }\end{array}$


Analysis 19.1. Comparison 19 Water quality intervention versus control: by sanitation level (longitudinal prevalence ratios), Outcome I Diarrhoea: all ages.

Review: Interventions to improve water quality for preventing diarrhoea

Comparison: 19 Water quality intervention versus control: by sanitation level (longitudinal prevalence ratios)

Outcome: I Diarrhoea: all ages

Study or subgroup Long. prev. Long. prev.

(SE) IV,Random,95\% Cl IV,Random,95\% Cl

\begin{tabular}{ll}
\hline $\begin{array}{l}\text { I Improved sanitation } \\
\text { du Preez 2004 }\end{array}$ & $-1.5606(0.544$ I) \\
Luby 2004b-i & $-0.7985(0.3123)$ \\
Luby 2004b-ii & $-0.7985(0.3062)$ \\
Luby 2004b-iii & $-1.0217(0.3465)$
\end{tabular}

$0.21[0.07,0.61]$

$0.45[0.24,0.83]$

ubtotal (95\% CI)

Heterogeneity: $\operatorname{Tau}^{2}=0.0 ; \mathrm{Chi}^{2}=1.77, \mathrm{df}=3(\mathrm{P}=0.62) ; \mathrm{I}^{2}=0.0 \%$

Test for overall effect: $Z=5.34(P<0.0000$ I $)$

2 Unimproved sanitation

$\begin{array}{ll}\text { Chiller } 2004 & -0.478(0.1426) \\ \text { Doocy } 2004 & -2.1203(0.0408) \\ \text { Kirchhoff I } 985 & 0.0677(0.0993)\end{array}$

$23.1 \%$

$25.7 \%$

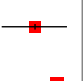

$\mp$

+
+

$\rightarrow$

$\checkmark$

$25.8 \%$

$25.4 \%$

$100.0 \%$

$33.1 \%$

$33.5 \%$

$33.3 \%$

$100.0 \%$
$0.45[0.25,0.82]$

$0.36[0.18,0.71]$

$0.39[0.28,0.55$ ]

$0.62[0.47,0.82]$

$0.12[0.11,0.13]$

$1.07[0.88,1.30]$

Subtotal $(95 \%$ CI)

Heterogeneity: $\mathrm{Tau}^{2}=1.95 ; \mathrm{Ch}^{2}=496.22, \mathrm{df}=2(\mathrm{P}<0.0000 \mathrm{I}) ; \mathrm{I}^{2}=100 \%$

Test for overall effect: $Z=1.05(P=0.29)$ 


\section{Analysis 20.1. Comparison 20 Water quality intervention versus control: simple and compound interventions (rate ratios), Outcome I Diarrhoea: all ages.}

Review: Interventions to improve water quality for preventing diarrhoea

Comparison: 20 Water quality intervention versus control: simple and compound interventions (rate ratios)

Outcome: I Diarrhoea: all ages

Study or subgroup $\quad$ log [Risk ratio] Risk ratio Risk ratio

(SE) IV,Random,95\% Cl
IV,Random,95\% Cl

I Water quality only

Colford 2002

$-0.6162(0.342)$

du Preez 2004

$-1.5606(0.544 \mid)$

Jensen 2003

$-0.0619(0.1288)$

$+$

Subtotal $(95 \% \mathrm{CI})$

Heterogeneity: $\mathrm{Tau}^{2}=0.33 ; \mathrm{Chi}^{2}=8.88, \mathrm{df}=2(\mathrm{P}=0.0 \mathrm{I}) ; \mathrm{I}^{2}=77 \%$

Test for overall effect: $Z=1.56(P=0.12)$

2 Water quality + hygiene promotion

$\begin{array}{lr}\text { Alam } 1989 & -0.1863(0.0795) \\ \text { Aziz } 1990 & -0.2877(0.0329) \\ \text { Gasana } 2002 & 0(0.0578)\end{array}$

Subtotal (95\% CI)

Heterogeneity: $\mathrm{Tau}^{2}=0.02 ; \mathrm{Chi}^{2}=18.85, \mathrm{df}=2(\mathrm{P}=0.00008) ; \mathrm{I}^{2}=89 \%$

Test for overall effect: $Z=1.66(P=0.097)$

3 Water quality + vessel

$\begin{array}{lc}\text { Handzel } 1998 & -0.4005(0.1093) \\ \text { Luby 2004a-i } & -0.5108(0.1717) \\ \text { Luby 2004a-ii } & -1.204(0.2806) \\ \text { Lule 2005 } & -0.2231(0.1138)\end{array}$

Subtotal (95\% CI)

Heterogeneity: $\mathrm{Tau}^{2}=0.06 ; \mathrm{Chi}^{2}=1 \mathrm{I} .04, \mathrm{df}=3(\mathrm{P}=0.0 \mathrm{I}) ; \mathrm{I}^{2}=73 \%$

Test for overall effect: $Z=3.43(P=0.0006 \mathrm{I})$

4 Water quality + sanitation

$$
\text { Aziz } 1990 \quad-0.2877(0.0329)
$$

Subtotal $(\mathbf{9 5} \% \mathrm{CI})$

Heterogeneity: not applicable

Test for overall effect: $Z=8.74(P<0.00001)$

5 Water quality + improved water supply

Alam 1989 


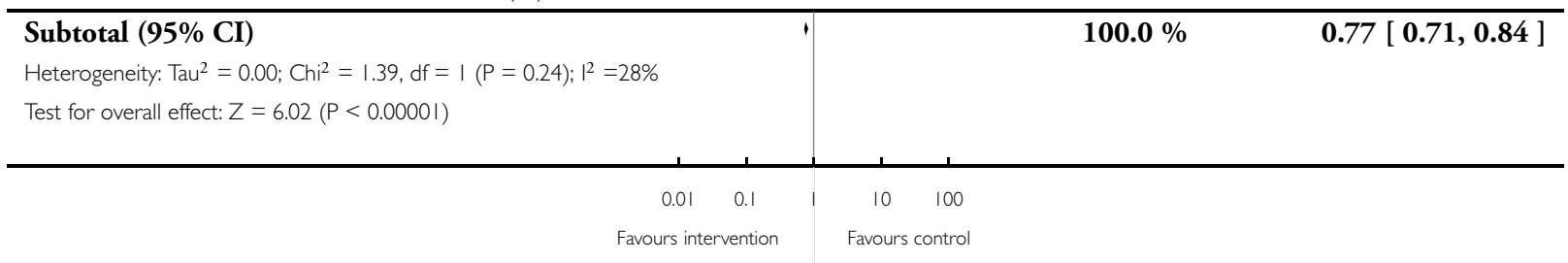

\section{Analysis 21.I. Comparison 21 Water quality intervention versus control: simple and compound interventions (risk ratios), Outcome I Diarrhoea: all ages.}

Review: Interventions to improve water quality for preventing diarrhoea

Comparison: 21 Water quality intervention versus control: simple and compound interventions (risk ratios)

Outcome: I Diarrhoea: all ages

Study or subgroup $\quad \log$ [Risk ratio] Risk ratio $\quad$ Weight ratio

IV,Random,95\% C

IV,Random,95\% Cl

$\begin{array}{ll}\text { I Water quality only } & \\ \text { Mahfouz I995 } & -0.5978(0.305) \\ \text { URL 1995-i } & -0.755(0.4476)\end{array}$

Subtotal (95\% CI)

Heterogeneity: $\operatorname{Tau}^{2}=0.0 ; \mathrm{Chi}^{2}=0.08, \mathrm{df}=\mathrm{I}(\mathrm{P}=0.77) ; \mathrm{I}^{2}=0.0 \%$

Test for overall effect: $Z=2.57(P=0.010)$

2 Water quality + hygiene promotion

Garrett $2004 \quad-0.821(0.2295)$

Semenza 1998

$-1.897 \mid(0.3704)$

URL 1995-ii

$-1.0498(0.4931)$

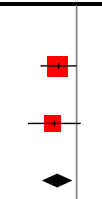

$57.2 \%$

$0.55[0.30,1.00]$

Subtotal $(95 \%$ CI $)$

(2)

Heterogeneity: $\mathrm{Tau}^{2}=0.25 ; \mathrm{Chi}^{2}=6.12, \mathrm{df}=2(\mathrm{P}=0.05) ; \mathrm{I}^{2}=67 \%$

Test for overall effect: $Z=3.45(P=0.00057)$

3 Water quality + vessel

Roberts 200I

$-0.2357(0.1353)$

Semenza 1998

$-1.897 \mid(0.3704)$

$59.8 \%$

$0.79[0.61,1.03]$

$40.2 \%$

$0.15[0.07,0.31]$

$\begin{array}{llllll}0.01 & 0.1 & 1 & 10 & 100\end{array}$

Favours intervention

Favours control

(Continued ... )

Interventions to improve water quality for preventing diarrhoea (Review)

Copyright (c) 2009 The Cochrane Collaboration. Published by John Wiley \& Sons, Ltd. 


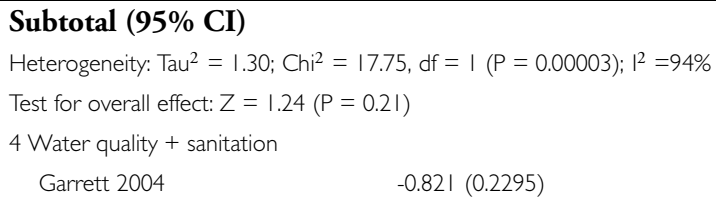

Heterogeneity: $\mathrm{Tau}^{2}=1.30 ; \mathrm{Chi}^{2}=17.75, \mathrm{df}=$ । $(\mathrm{P}=0.00003) ; \mathrm{I}^{2}=94 \%$

Test for overall effect: $Z=1.24(P=0.21)$

4 Water quality + sanitation
Garrett 2004

Subtotal (95\% CI)

Heterogeneity: not applicable

Test for overall effect: $Z=3.58(P=0.00035)$

5 Water quality + improved water supply
Garrett 2004
$-0.821(0.2295)$

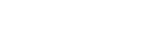

$+$

Subtotal (95\% CI)

$100.0 \%$

$0.44[0.28,0.69]$

Test for overall effect: $Z=3.58(P=0.00035)$

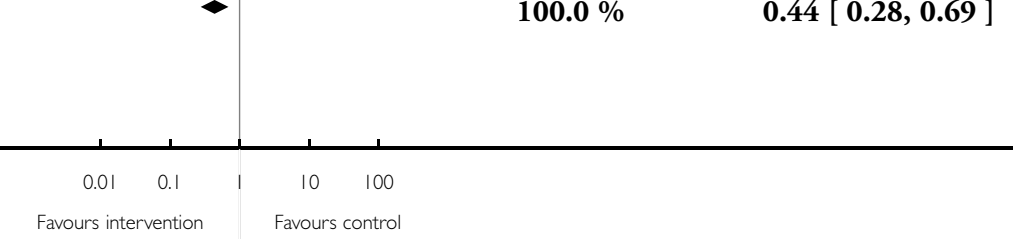


Analysis 22.1. Comparison 22 Water quality intervention versus control: simple and compound interventions (longitudinal prevalence ratios), Outcome I Diarrhoea: all ages.

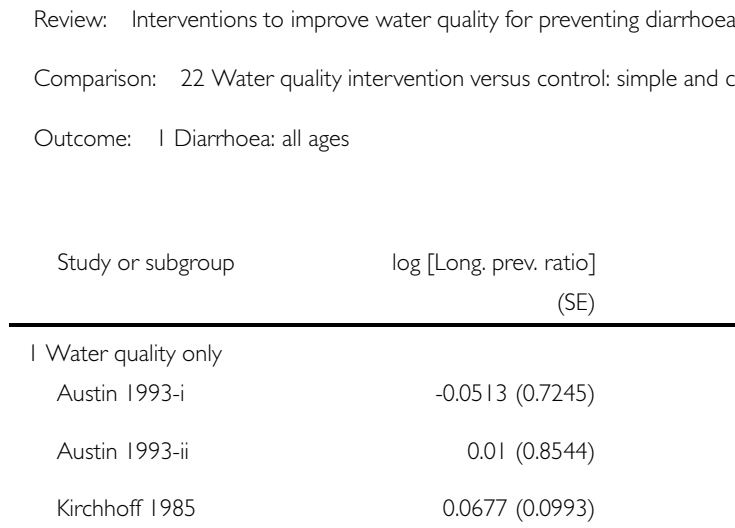

\begin{tabular}{lr}
\hline I Water quality only & \\
Austin 1993-i & $-0.0513(0.7245)$ \\
Austin 1993-ii & $0.01(0.8544)$ \\
Kirchhoff 1985 & $0.0677(0.0993)$
\end{tabular}

Subtotal $(95 \% \mathrm{CI})$

Heterogeneity: $\operatorname{Tau}^{2}=0.0 ; \mathrm{Chi}^{2}=0.03, \mathrm{df}=2(\mathrm{P}=0.98) ; \mathrm{I}^{2}=0.0 \%$

Test for overall effect: $Z=0.66(P=0.5 \mathrm{I})$

2 Water quality + hygiene promotion

$\begin{array}{lc}\text { Chiller 2004 } & -0.478(0.1426) \\ \text { Crump 2004-i } & -0.2614(0.1072) \\ \text { Crump 2004-ii } & -0.1863(0.1101) \\ \text { Luby 2004b-ii } & -0.7985(0.3062)\end{array}$

Subtotal (95\% CI)

Heterogeneity: $\operatorname{Tau}^{2}=0.02 ; \mathrm{Chi}^{2}=5.40, \mathrm{df}=3(\mathrm{P}=0.14) ; \mathrm{I}^{2}=44 \%$

Test for overall effect: $Z=3.53(P=0.0004 \mathrm{I})$

3 Water quality + vessel

$\begin{array}{ll}\text { Doocy } 2004 & -2.1203(0.0408) \\ \text { Luby 2004b-i } & -0.7985(0.3123) \\ \text { Luby 2004b-iii } & -1.0217(0.3465)\end{array}$

Subtotal (95\% CI)

Heterogeneity: $\mathrm{Tau}^{2}=0.69 ; \mathrm{Chi}^{2}=27 . \mathrm{I}, \mathrm{df}=2(\mathrm{P}<0.0000 \mathrm{I}) ; \mathrm{I}^{2}=93 \%$

Test for overall effect: $Z=2.68(P=0.0073)$

4 Water quality + sanitation

Messou 1997

$-0.5798(0.2069)$

Subtotal (95\% CI)

Heterogeneity: not applicable

Test for overall effect: $Z=2.80(P=0.005 \mathrm{I})$

5 Water quality + improved water supply

Messou 1997

$-0.5798(0.2069)$
$100.0 \%$

$100.0 \%$

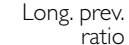

IV,Random,95\% Cl

Weight

Long. prev.

IV,Random,95\% Cl

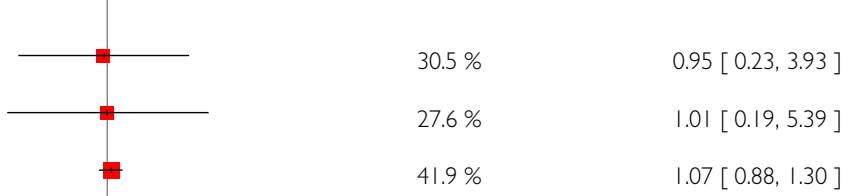

$100.0 \%$

$1.07[0.88,1.29]$

$25.2 \%$

$0.62[0.47,0.82]$

$25.4 \%$

$0.77[0.62,0.95$ ]

$25.4 \%$

$0.83[0.67,1.03]$

$24.0 \%$

$0.45[0.25,0.82]$

$100.0 \%$

$0.71[0.59,0.86$ ]

$35.0 \%$

$0.12[0.11,0.13]$

$32.7 \%$

$0.45[0.24,0.83]$

$32.2 \%$

$0.36[0.18,0.7 \mid]$

$100.0 \%$

$0.26[0.10,0.69]$

0.56 [0.37, 0.84$]$

$0.56[0.37,0.84]$

$100.0 \%$

$0.56[0.37,0.84]$

\begin{tabular}{lll|lll}
0.1 & 0.2 & 0.5 & 2 & 5 & 10
\end{tabular}

Favours intervention Favours control

(Continued... ) 


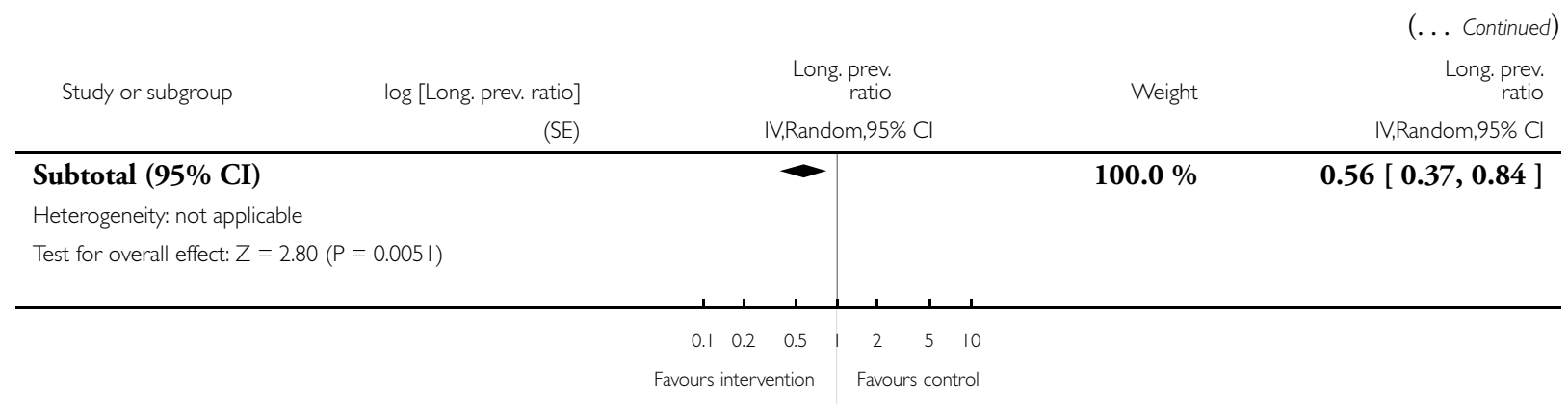

\section{Analysis 23.1. Comparison 23 Water quality intervention versus control: simple and compound interventions (odds ratios), Outcome I Diarrhoea: all ages.}

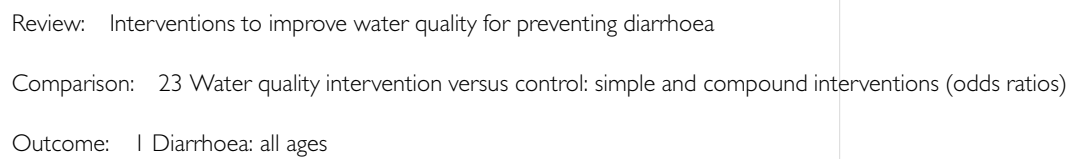

\begin{tabular}{ll}
\hline $\begin{array}{l}\text { I Water quality only } \\
\text { Clasen 2004b }\end{array}$ & $-0.755(0.3427)$ \\
Clasen 2004c & $-1.204(0.2291)$ \\
Conroy 1996 & $-0.4155(0.1409)$ \\
Conroy 1999 & -0.37 II (0.0425) \\
Reller 2003-i & $-0.2357(0.1$ I I I) \\
Reller 2003-ii & $-0.3011(0.11$ II)
\end{tabular}

Subtotal (95\% CI)

Heterogeneity: $\mathrm{Tau}^{2}=0.03 ; \mathrm{Chi}^{2}=16.31, \mathrm{df}=5(\mathrm{P}=0.0 \mathrm{I}) ; \mathrm{I}^{2}=69 \%$

Test for overall effect: $Z=4.84(P<0.0000 \mathrm{I})$

2 Water quality + hygiene promotion

Quick 2002

Subtotal (95\% CI) 


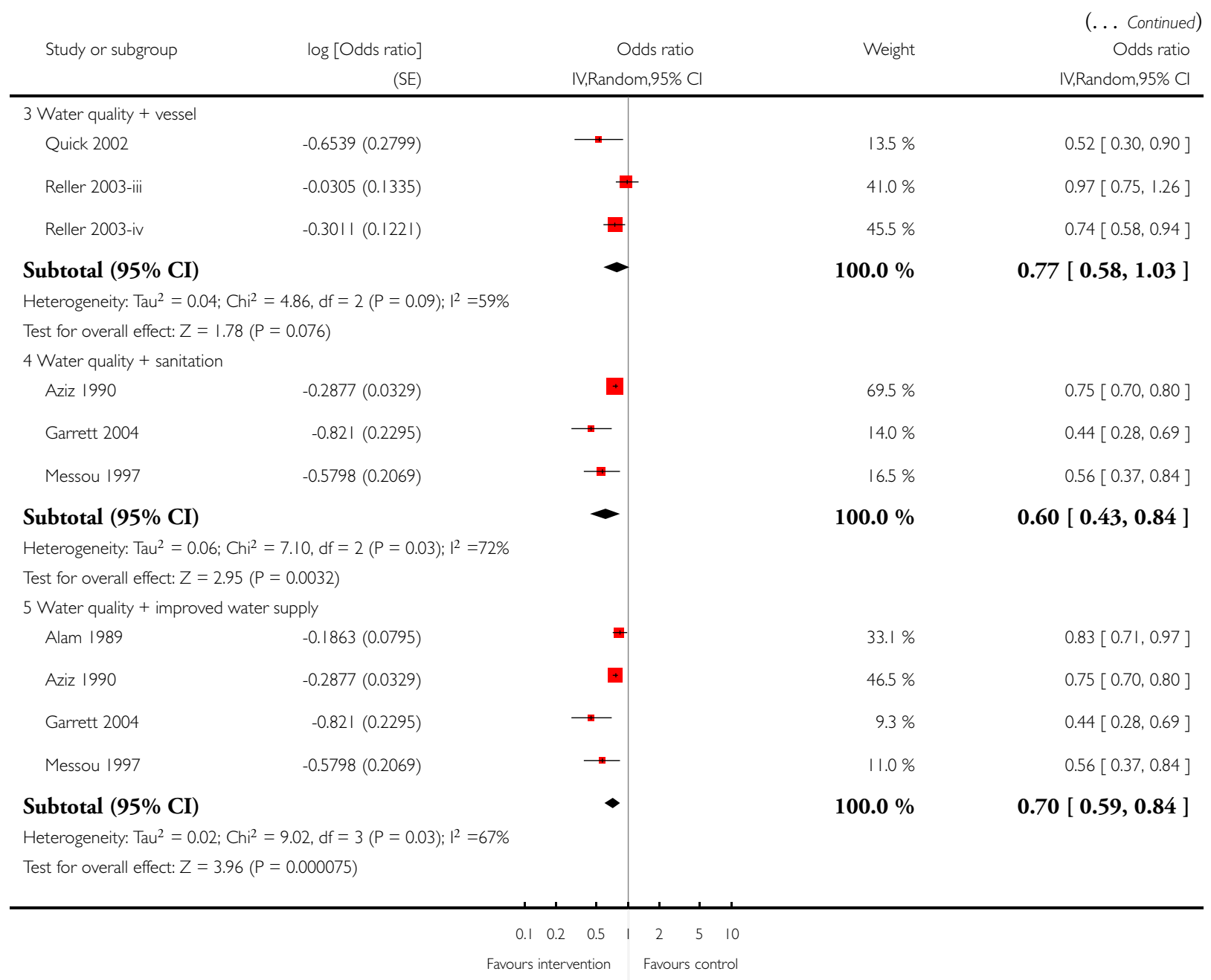


Analysis 24.I. Comparison 24 Water quality intervention versus control for RCTs: by methodological quality (rate ratios), Outcome I Diarrhoea: by allocation sequence.

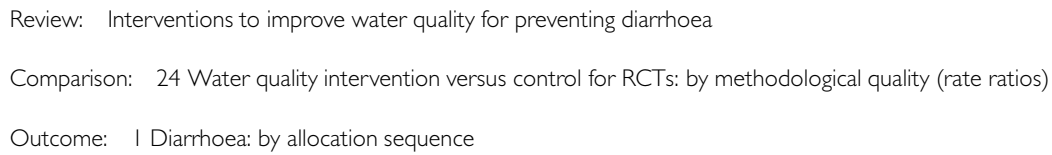

(1)

Subtotal (95\% CI)

$\longrightarrow$

Heterogeneity: Tau $^{2}=0.24 ; \mathrm{Chi}^{2}=2.16, \mathrm{df}=\mathrm{I}(\mathrm{P}=0.14) ; \mathrm{I}^{2}=54 \%$

Test for overall effect: $Z=2.15(P=0.032)$

2 Unclear

$$
\begin{array}{ll}
\text { Handzel } 1998 & -0.4005(0.1093) \\
\text { Lule } 2005 & -0.2231(0.1138)
\end{array}
$$

Subtotal (95\% CI)

Heterogeneity: $\mathrm{Tau}^{2}=0.00 ; \mathrm{Chi}^{2}=1.26, \mathrm{df}=\mathrm{I}(\mathrm{P}=0.26) ; \mathrm{I}^{2}=21 \%$

Test for overall effect: $Z=3.55(P=0.00039)$

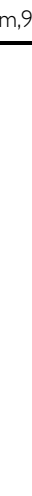

Weight

, Random, $95 \%$ CI

\section{$68.1 \%$}

$31.9 \%$

$100.0 \%$

$50.5 \%$

$49.5 \%$

$100.0 \%$
$0.54[0.28,1.06]$

$0.21[0.07,0.61]$

0.37 [ $0.15,0.92$ ]

$0.67[0.54,0.83]$

$0.80[0.64,1.00]$

$\begin{array}{lllllll}0.01 & 0.1 & 1 & 10 & 100 \\ \text { Favours intervention } & \text { Favours control }\end{array}$ 
Analysis 24.2. Comparison 24 Water quality intervention versus control for RCTs: by methodological quality (rate ratios), Outcome 2 Diarrhoea: by allocation concealment.

Review: Interventions to improve water quality for preventing diarrhoea

Comparison: 24 Water quality intervention versus control for RCTs: by methodological quality (rate ratios)

Outcome: 2 Diarrhoea: by allocation concealment

Study or subgroup $\quad \log$ [Rate ratio] Rate ratio Reight ratio

(SE) IV,Random,95\% Cl

IV,Random,95\% Cl

I Adequate

Colford 2002

$-0.6162(0.342)$

du Preez 2004

$-1.5606(0.544 \mid)$

Handzel 1998

$-0.4005(0.1093)$

Lule 2005

$-0.2231(0.1138)$

Subtotal (95\% CI)

Heterogeneity: $\mathrm{Tau}^{2}=0.04 ; \mathrm{Chi}^{2}=7.0 \mathrm{l}, \mathrm{df}=3(\mathrm{P}=0.07) ; \mathrm{I}^{2}=57 \%$

Test for overall effect: $Z=2.96(P=0.0031)$

2 Inadequate

$\begin{array}{ll}\text { Conroy 1996 } & -0.4155(0.1409) \\ \text { Conroy 1999 } & -0.3711(0.0425) \\ \text { Kirchhoff 1985 } & 0.0677(0.0993) \\ \text { Roberts 200 I } & -0.2357(0.1353)\end{array}$

Subtotal (95\% CI)

Heterogeneity: $\mathrm{Tau}^{2}=0.04 ; \mathrm{Chi}^{2}=17.38, \mathrm{df}=3(\mathrm{P}=0.00059) ; \mathrm{I}^{2}=83 \%$

Test for overall effect: $Z=2.04(P=0.04 I)$

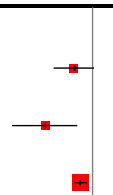

$+$

\section{$\bullet$}

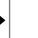

(1)

$+$

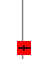

$\pm$

-
$12.1 \%$

$5.5 \%$

$41.7 \%$

$40.7 \%$

$100.0 \%$

$20.7 \%$

$32.1 \%$

$25.8 \%$

$21.4 \%$

$100.0 \%$
$0.54[0.28,1.06]$

$0.21[0.07,0.61]$

$0.67[0.54,0.83]$

$0.80[0.64,1.00]$

$0.65[0.49,0.86]$

$0.66[0.50,0.87]$

$0.69[0.63,0.75]$

$1.07[0.88,1.30]$

$0.79[0.61,1.03]$

$0.79[0.63,0.99]$

Favours intervention

$10 \quad 100$

Favours control 


\section{Analysis 24.3. Comparison 24 Water quality intervention versus control for RCTs: by methodological quality (rate ratios), Outcome 3 Diarrhoea: by follow up.}

Review: Interventions to improve water quality for preventing diarrhoea

Comparison: 24 Water quality intervention versus control for RCTs: by methodological quality (rate ratios)

Outcome: 3 Diarrhoea: by follow up

Study or subgroup $\quad \log$ [Rate ratio] Rate ratio Reight ratio

(SE) IV,Random,95\% Cl

IV,Random,95\% Cl

\begin{tabular}{|c|c|}
\hline \multicolumn{2}{|l|}{ I Adequate } \\
\hline Colford 2002 & $-0.6162(0.342)$ \\
\hline du Preez 2004 & $-1.5606(0.544 I)$ \\
\hline Handzel 1998 & $-0.4005(0.1093)$ \\
\hline Lule 2005 & $-0.2231(0.1138)$ \\
\hline
\end{tabular}

Subtotal (95\% CI)

Heterogeneity: Tau $^{2}=0.04 ; \mathrm{Chi}^{2}=7.0 \mathrm{l}, \mathrm{df}=3(\mathrm{P}=0.07) ; \mathrm{I}^{2}=57 \%$

Test for overall effect: $Z=2.96(P=0.0031)$

2 Unclear

$\begin{array}{lr}\text { Semenza I998 } & -1.897 \text { I }(0.3704) \\ \text { URL 1995-i } & -0.755(0.4476) \\ \text { URL 1995-ii } & -1.0498(0.493 \text { I) }\end{array}$

Subtotal (95\% CI)

Heterogeneity: Tau $^{2}=0.22 ; \mathrm{Chi}^{2}=4.32, \mathrm{df}=2(\mathrm{P}=0.12) ; \mathrm{I}^{2}=54 \%$

Test for overall effect: $Z=3.47(P=0.00053)$

3 Inadequate

\begin{tabular}{|c|c|}
\hline Austin 1993-i & $-0.0513(0.7245)$ \\
\hline Austin 1993-ii & $0.01(0.8544)$ \\
\hline Conroy 1999 & $-0.37 \mid I(0.0425)$ \\
\hline Crump 2004-i & $-0.2614(0.1072)$ \\
\hline Crump 2004-ii & $-0.1863(0.1101)$ \\
\hline Kirchhoff 1985 & $0.0677(0.0993)$ \\
\hline Reller 2003-i & $-0.2357(0.1|5|)$ \\
\hline Reller 2003-ii & $-0.301 \mid(0.11 \mid 1)$ \\
\hline Reller 2003-iii & $-0.0305(0.1335)$ \\
\hline Reller 2003-iv & $-0.3011(0.1221)$ \\
\hline Roberts 200I & $-0.2357(0.1353)$ \\
\hline
\end{tabular}

$0.54[0.28,1.06]$

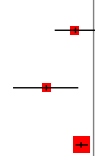

$12.3 \%$

$5.6 \%$

$41.5 \%$

$0.21[0.07,0.61]$ 
Analysis 24.4. Comparison 24 Water quality intervention versus control for RCTs: by methodological quality (rate ratios), Outcome 4 Diarrhoea: by blinding.

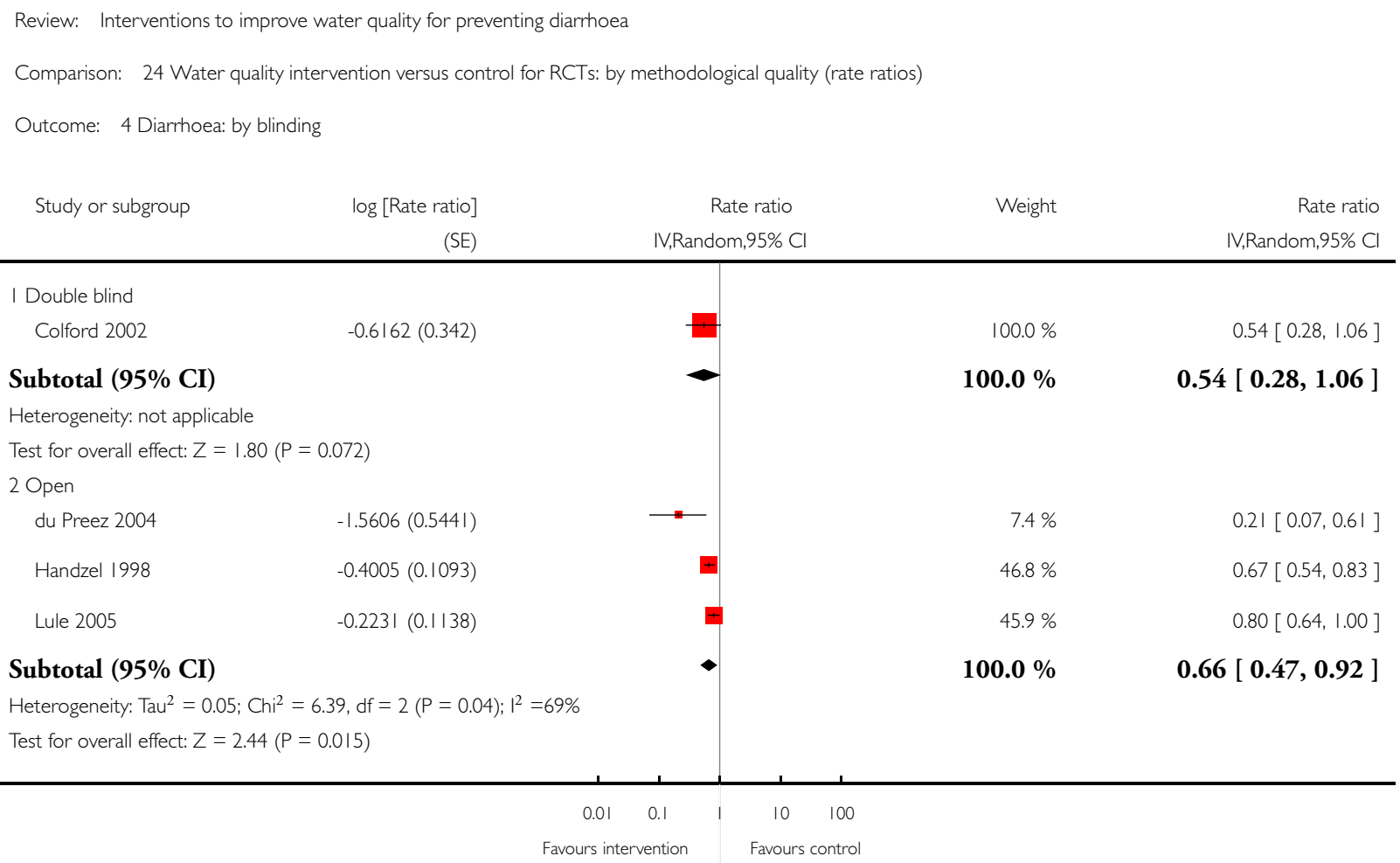


Analysis 25.I. Comparison 25 Water quality intervention versus control for RCTs: by methodological quality (risk ratios), Outcome I Diarrhoea: by allocation sequence.

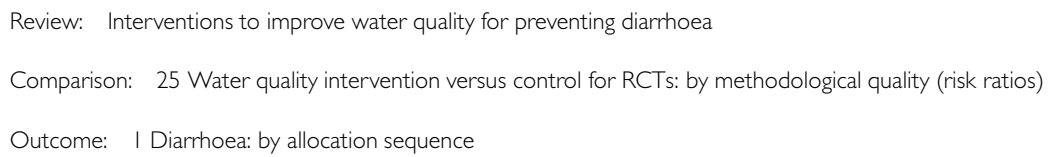

Subtotal (95\% CI)

Heterogeneity: $\mathrm{Tau}^{2}=0.22 ; \mathrm{Chi}^{2}=4.32, \mathrm{df}=2(\mathrm{P}=0.12) ; \mathrm{I}^{2}=54 \%$

Test for overall effect: $Z=3.47(P=0.00053)$

2 Inadequate

$$
\text { Roberts 2001 } \quad-0.2357(0.1353)
$$

Subtotal (95\% CI)

Heterogeneity: not applicable

Test for overall effect: $Z=1.74(P=0.081)$

$\begin{array}{llllll}0.01 & 0.1 & 1 & 10 & 100 \\ \text { Favours intervention } & \text { Favours control }\end{array}$


Analysis 25.2. Comparison 25 Water quality intervention versus control for RCTs: by methodological quality (risk ratios), Outcome 2 Diarrhoea: by allocation concealment.

Review: Interventions to improve water quality for preventing diarrhoea

Comparison: 25 Water quality intervention versus control for RCTs: by methodological quality (risk ratios)

Outcome: 2 Diarrhoea: by allocation concealment

Study or subgroup log [Risk ratio] Risk ratio Reight

(SE) IV,Random,95\% Cl

IV,Random,95\% Cl

\begin{tabular}{ll}
\hline I Adequate & \\
Semenza 1998 & -1.897 | (0.3704) \\
URL 1995-i & $-0.755(0.4476)$ \\
URL | 995-ii & $-1.0498(0.493$ ।)
\end{tabular}

Subtotal (95\% CI)

$-\quad+35.8 \%$

$0.15[0.07,0.31]$

$\rightarrow \quad 33.0 \%$

$31.3 \%$

$0.47[0.20,1.13]$

$\longrightarrow$

Heterogeneity: $\mathrm{Tau}^{2}=0.22 ; \mathrm{Chi}^{2}=4.32, \mathrm{df}=2(\mathrm{P}=0.12) ; \mathrm{I}^{2}=54 \%$

Test for overall effect: $Z=3.47(P=0.00053)$

2 Inadequate

Roberts 200

Subtotal (95\% CI)

$100.0 \%$

$0.79[0.61,1.03]$

Heterogeneity: not applicable

Test for overall effect: $Z=1.74(P=0.081)$

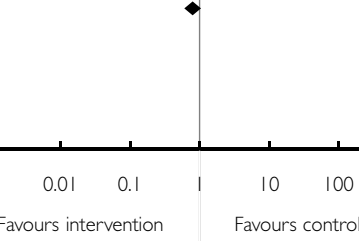


Analysis 25.3. Comparison 25 Water quality intervention versus control for RCTs: by methodological quality (risk ratios), Outcome 3 Diarrhoea: by follow up.

Review: Interventions to improve water quality for preventing diarrhoea

Comparison: 25 Water quality intervention versus control for RCTs: by methodological quality (risk ratios)

Outcome: 3 Diarrhoea: by follow up

Study or subgroup log [Risk ratio] Risk ratio Reight

(SE) IV,Random,95\% Cl

IV,Random,95\% Cl

I Unclear

Semenza $1998 \quad-1.8971(0.3704)$

URL 1995-i $\quad-0.755(0.4476)$

URL 1995-ii $\quad-1.0498(0.4931)$

Subtotal (95\% CI)

Heterogeneity: $\mathrm{Tau}^{2}=0.22 ; \mathrm{Chi}^{2}=4.32, \mathrm{df}=2(\mathrm{P}=0.12) ; \mathrm{I}^{2}=54 \%$

Test for overall effect: $Z=3.47(P=0.00053)$

2 Inadequate

$$
\text { Roberts 200I } \quad-0.2357(0.1353)
$$

(1)

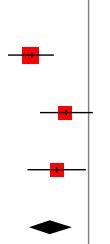

Subtotal (95\% CI)

Heterogeneity: not applicable

Test for overall effect: $Z=1.74(P=0.081)$

$\begin{array}{rr}35.8 \% & 0.15[0.07,0.31] \\ 33.0 \% & 0.47[0.20,1.13] \\ 31.3 \% & 0.35[0.13,0.92] \\ \mathbf{1 0 0 . 0} \% & \mathbf{0 . 2 8}[\mathbf{0 . 1 4}, \mathbf{0 . 5 7}]\end{array}$

$100.0 \%$

$0.79[0.61,1.03]$

$100.0 \%$

0.79 [ $0.61,1.03$ ] 
Analysis 25.4. Comparison 25 Water quality intervention versus control for RCTs: by methodological quality (risk ratios), Outcome 4 Diarrhoea: by blinding.

Review: Interventions to improve water quality for preventing diarrhoea

Comparison: 25 Water quality intervention versus control for RCTs: by methodological quality (risk ratios)

Outcome: 4 Diarrhoea: by blinding

Study or subgroup log [Risk ratio] Risk ratio Reight

(SE) IV,Random,95\% Cl

IV,Random,95\% Cl

I Open

Roberts 200I

$-0.2357(0.1353)$

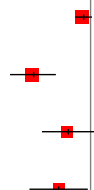

Semenza 1998

$-1.897 \mid(0.3704)$

URL 1995-i

$-0.755(0.4476)$

URL 1995-ii

$-1.0498(0.493 \mid)$

ren

Subtotal (95\% CI)

Heterogeneity: $\operatorname{Tau}^{2}=0.60 ; \mathrm{Chi}^{2}=19.60, \mathrm{df}=3(\mathrm{P}=0.0002 \mathrm{I}) ; \mathrm{I}^{2}=85 \%$

Test for overall effect: $Z=2.21(P=0.027)$

$0.01 \quad 0.1$

$10 \quad 100$

Favours intervention

Favours control

$\begin{array}{ll}29.9 \% & 0.79[0.61,1.03] \\ 25.1 \% & 0.15[0.07,0.31] \\ 23.1 \% & 0.47[0.20,1.13] \\ 21.9 \% & 0.35[0.13,0.92]\end{array}$

$100.0 \%$

$0.39[0.17,0.90]$ 
Analysis 26.I. Comparison 26 Water quality intervention versus control for RCTs: by methodological quality (longitudinal prevalence ratios), Outcome I Diarrhoea: allocation sequence.

Review: Interventions to improve water quality for preventing diarrhoea

Comparison: 26 Water quality intervention versus control for RCTs: by methodological quality (longitudinal prevalence ratios)

Outcome: I Diarrhoea: allocation sequence

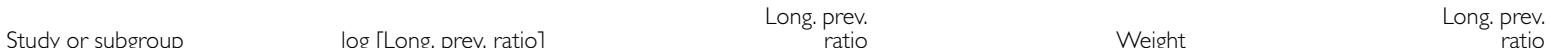

(SE) IV,Random,95\% Cl IV,Random,95\% Cl

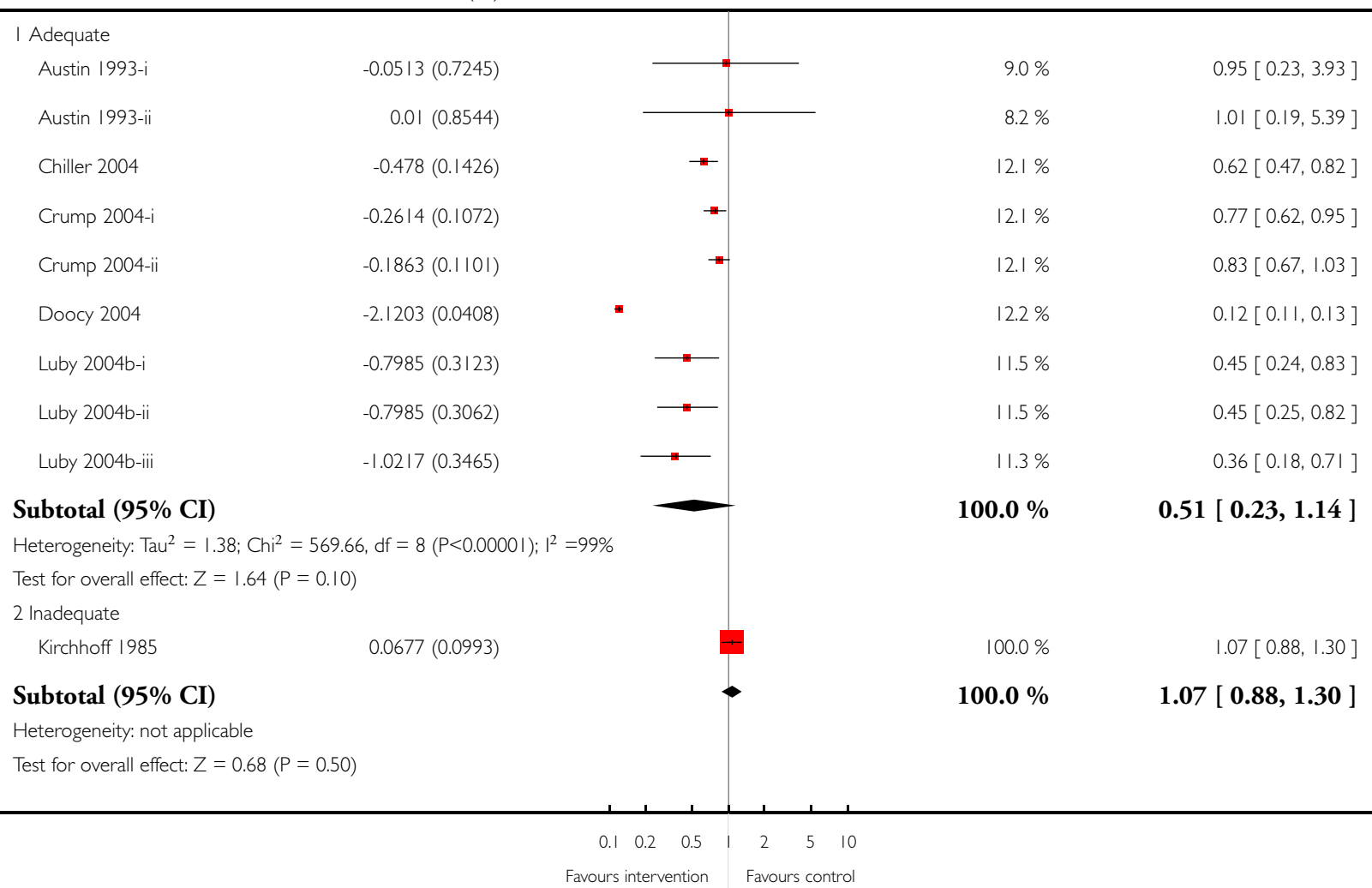

Interventions to improve water quality for preventing diarrhoea (Review) 
Analysis 26.2. Comparison 26 Water quality intervention versus control for RCTs: by methodological quality (longitudinal prevalence ratios), Outcome 2 Diarrhoea: by allocation concealment.

Review: Interventions to improve water quality for preventing diarrhoea

Comparison: 26 Water quality intervention versus control for RCTs: by methodological quality (longitudinal prevalence ratios)

Outcome: 2 Diarrhoea: by allocation concealment

Study or subgroup $\quad \log$ [Long. prev. ratio]

(SE)

\begin{tabular}{lr}
\hline I Adequate & \\
Austin 1993-i & $-0.0513(0.7245)$ \\
Austin 1993-ii & $0.01(0.8544)$ \\
Chiller 2004 & $-0.478(0.1426)$ \\
Crump 2004-i & $-0.2614(0.1072)$ \\
Crump 2004-ii & $-0.1863(0.1101)$ \\
Doocy 2004 & $-2.1203(0.0408)$ \\
Luby 2004b-i & $-0.7985(0.3123)$ \\
Luby 2004b-ii & $-0.7985(0.3062)$ \\
Luby 2004b-iii & $-1.0217(0.3465)$
\end{tabular}

Subtotal $(\mathbf{9 5 \%} \mathrm{CI})$

Heterogeneity: $\mathrm{Tau}^{2}=1.38 ; \mathrm{Chi}^{2}=569.66, \mathrm{df}=8(\mathrm{P}<0.0000 \mathrm{I}) ; \mathrm{I}^{2}=99 \%$

Test for overall effect: $Z=1.64(P=0.10)$

2 Inadequate

Kirchhoff 1985

$0.0677(0.0993)$

Subtotal $(95 \%$ CI $)$

Heterogeneity: not applicable

Test for overall effect: $Z=0.68(P=0.50)$
Long. prev.

Weight

Long. prev.

IV,Random,95\% Cl

IV,Random,95\% C

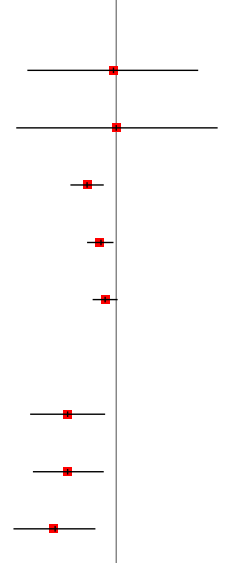

$9.0 \%$

$0.95[0.23,3.93]$

$8.2 \%$

$1.01[0.19,5.39]$

$12.1 \%$

$0.62[0.47,0.82]$

$12.1 \%$

$0.77[0.62,0.95]$

$12.1 \%$

$0.83[0.67,1.03]$

$12.2 \%$

$0.12[0.11,0.13]$

| $1.5 \%$

$0.45[0.24,0.83]$

$11.5 \%$

$0.45[0.25,0.82]$

$11.3 \%$

$0.36[0.18,0.7 \mid]$

$100.0 \%$

$0.51[0.23,1.14]$

$100.0 \%$

$1.07[0.88,1.30]$

$100.0 \%$

$1.07[0.88,1.30]$

$\begin{array}{lllllll}0.1 & 0.2 & 0.5 & 1 & 2 & 5 & 10\end{array}$

Favours intervention Favours control 
Analysis 26.3. Comparison 26 Water quality intervention versus control for RCTs: by methodological quality (longitudinal prevalence ratios), Outcome 3 Diarrhoea: by follow up.

Review: Interventions to improve water quality for preventing diarrhoea

Comparison: 26 Water quality intervention versus control for RCTs: by methodological quality (longitudinal prevalence ratios)

Outcome: 3 Diarrhoea: by follow up

Study or subgroup log [Long. prev. ratio]

(SE)

\begin{tabular}{ll}
\hline $\begin{array}{l}\text { Adequate } \\
\text { Chiller 2004 }\end{array}$ & $-0.478(0.1426)$ \\
Luby 2004b-i & $-0.7985(0.3123)$ \\
Luby 2004b-ii & $-0.7985(0.3062)$ \\
Luby 2004b-iii & $-1.0217(0.3465)$
\end{tabular}

Subtotal $(\mathbf{9 5 \%} \mathrm{CI})$

Heterogeneity: Tau $^{2}=0.00 ; \mathrm{Chi}^{2}=3.00, \mathrm{df}=3(\mathrm{P}=0.39) ; \mathrm{I}^{2}=0 \%$

Test for overall effect: $Z=5.50(P<0.0000$ I $)$

2 Inadequate

$$
\begin{array}{lr}
\text { Austin 1993-i } & -0.0513(0.7245) \\
\text { Austin 1993-ii } & 0.01(0.8544) \\
\text { Crump 2004-i } & -0.2614(0.1072) \\
\text { Crump 2004-ii } & -0.1863(0.1101) \\
\text { Kirchhoff 1985 } & 0.0677(0.0993)
\end{array}
$$

Subtotal $(95 \%$ CI)

Heterogeneity: $\mathrm{Tau}^{2}=0.01 ; \mathrm{Chi}^{2}=5.70, \mathrm{df}=4(\mathrm{P}=0.22) ; \mathrm{I}^{2}=30 \%$

Test for overall effect: $Z=1.46(P=0.15)$

$$
\begin{aligned}
& \text { Long. prev. } \\
& \text { ratio }
\end{aligned}
$$

Weight

IV,Random,95\% Cl
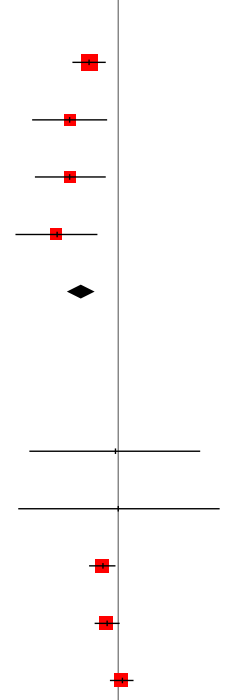

\section{$3.8 \%$}

$31.0 \%$

$30.7 \%$

$31.7 \%$

$100.0 \%$
$2.8 \%$

Long. prev.
ratio

IV,Random,95\% Cl

$\begin{array}{ll}40.4 \% & 0.62[0.47,0.82] \\ 20.6 \% & 0.45[0.24,0.83] \\ 21.1 \% & 0.45[0.25,0.82] \\ 8.0 \% & 0.36[0.18,0.71]\end{array}$

0.54 [ $0.43,0.67$ ]

$0.95[0.23,3.93]$

$1.01[0.19,5.39]$

$0.77[0.62,0.95]$

$0.83[0.67,1.03]$

$1.07[0.88,1.30]$ 
Analysis 26.4. Comparison 26 Water quality intervention versus control for RCTs: by methodological quality (longitudinal prevalence ratios), Outcome 4 Diarrhoea: by blinding.

Review: Interventions to improve water quality for preventing diarrhoea

Comparison: 26 Water quality intervention versus control for RCTs: by methodological quality (longitudinal prevalence ratios)

Outcome: 4 Diarrhoea: by blinding

Study or subgroup $\quad \log$ [Long. prev. ratio]

(SE)

\begin{tabular}{lr}
\hline | Double blind & \\
Austin 1993-i & $-0.0513(0.7245)$ \\
Austin 1993-ii & $0.01(0.8544)$ \\
Kirchhoff I985 & $0.0677(0.0993)$
\end{tabular}

Subtotal $(95 \% \mathrm{CI})$

Heterogeneity: $\mathrm{Tau}^{2}=0.0 ; \mathrm{Chi}^{2}=0.03, \mathrm{df}=2(\mathrm{P}=0.98) ; \mathrm{I}^{2}=0.0 \%$

Test for overall effect: $Z=0.66(P=0.5 \mathrm{I})$

2 Open

Chiller 2004

Crump 2004-i

Crump 2004-ii

Doocy 2004

Luby 2004b-i

Luby 2004b-ii

Luby 2004b-iii

Subtotal (95\% CI)

Heterogeneity: Tau $^{2}=1.38 ; \mathrm{Chi}^{2}=561.54, \mathrm{df}=6(\mathrm{P}<0.0000 \mathrm{I}) ; \mathrm{I}^{2}=99 \%$

Test for overall effect: $Z=1.79(P=0.073)$
$-0.478(0.1426)$

$-0.2614(0.1072)$

$-0.1863(0.1101)$

$-2.1203(0.0408)$

$-0.7985(0.3123)$

$-0.7985(0.3062)$

$-1.0217(0.3465)$

\#

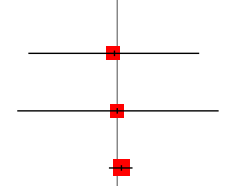

$30.8 \%$

$27.9 \%$

$41.3 \%$

$100.0 \%$

$14.6 \%$

$14.6 \%$

$14.6 \%$

$14.7 \%$

$13.9 \%$

$13.9 \%$

$13.7 \%$

$100.0 \%$
Long. prev. IV,Random,95\% Cl

$0.95[0.23,3.93]$

$1.01[0.19,5.39]$

$1.07[0.88,1.30]$

$1.07[0.88,1.29]$

$0.62[0.47,0.82]$

$0.77[0.62,0.95]$

$0.83[0.67,1.03]$

$0.12[0.11,0.13]$

$0.45[0.24,0.83]$

$0.45[0.25,0.82]$

$0.36[0.18,0.71]$

$0.45[0.18,1.08]$

$\begin{array}{lllllll}0.1 & 0.2 & 0.5 & 1 & 2 & 5 & 10\end{array}$

Favours intervention Favours control 
Analysis 27.I. Comparison 27 Water quality intervention versus control for RCTs: by methodological quality (odds ratios), Outcome I Diarrhoea: by allocation sequence.

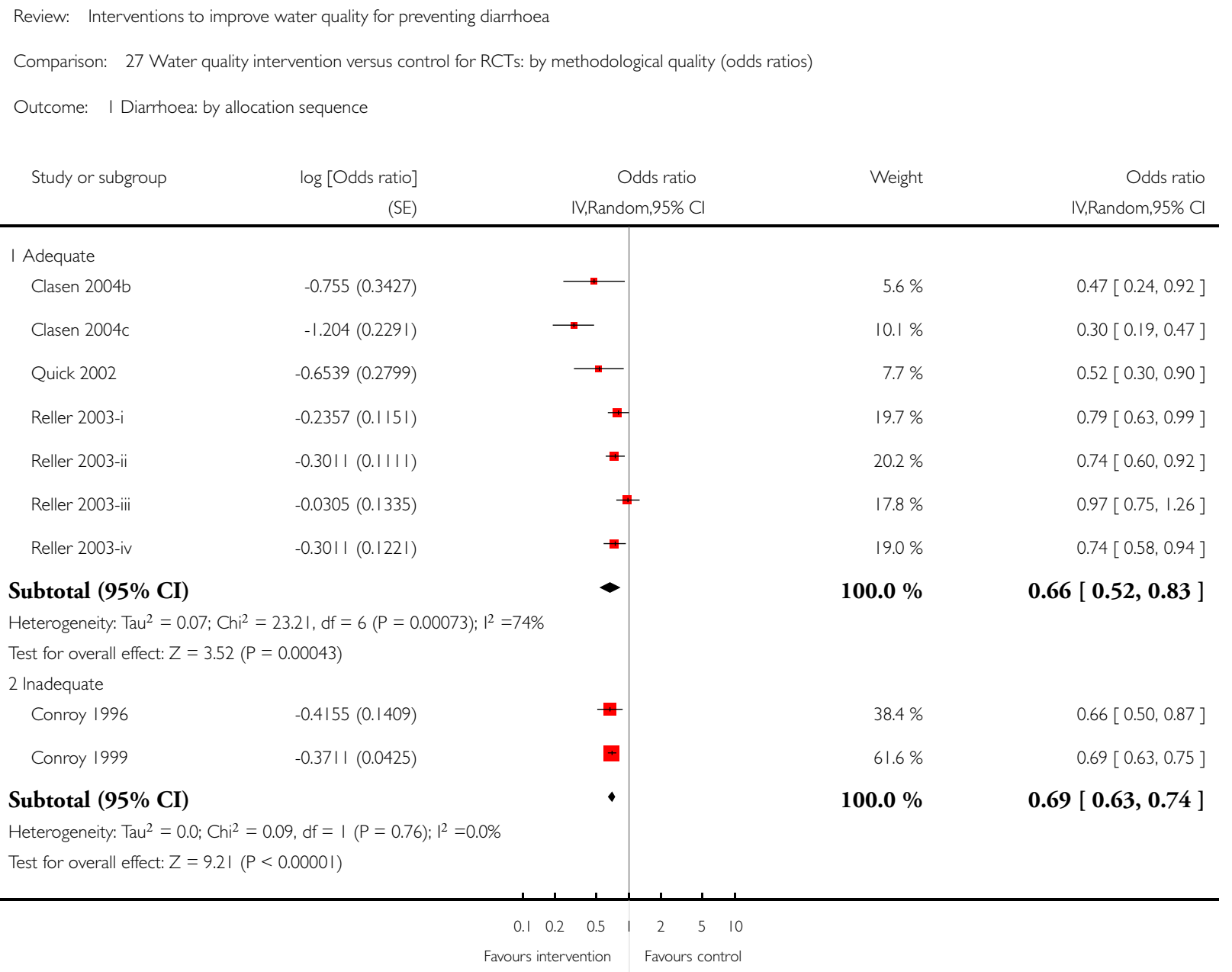


Analysis 27.2. Comparison 27 Water quality intervention versus control for RCTs: by methodological quality (odds ratios), Outcome 2 Diarrhoea: by allocation concealment.

Review: Interventions to improve water quality for preventing diarrhoea

Comparison: 27 Water quality intervention versus control for RCTs: by methodological quality (odds ratios)

Outcome: 2 Diarrhoea: by allocation concealment

Study or subgroup $\quad \log [$ Odds ratio] Odds ratio Odds ratio

IV,Random,95\% Cl

IV,Random,95\% Cl

$\begin{array}{ll}\begin{array}{l}\text { I Adequate } \\ \text { Clasen 2004b }\end{array} & -0.755(0.3427) \\ \text { Clasen 2004c } & -1.204(0.229 \text { I) } \\ \text { Quick 2002 } & -0.6539(0.2799) \\ \text { Reller 2003-i } & -0.2357(0.1 \text { I I I) } \\ \text { Reller 2003-ii } & -0.301 \text { I }(0.1 \text { I I I) } \\ \text { Reller 2003-iii } & -0.0305(0.1335) \\ \text { Reller 2003-iv } & -0.301 \text { I }(0.122 \text { I) }\end{array}$

Subtotal (95\% CI)

Heterogeneity: $\mathrm{Tau}^{2}=0.07 ; \mathrm{Chi}^{2}=23.21, \mathrm{df}=6(\mathrm{P}=0.00073) ; \mathrm{I}^{2}=74 \%$

Test for overall effect: $Z=3.52(P=0.00043)$

2 Inadequate

$\begin{array}{ll}\text { Conroy } 1996 & -0.4155(0.1409) \\ \text { Conroy } 1999 & -0.3711(0.0425)\end{array}$

Subtotal (95\% CI)

Heterogeneity: $\mathrm{Tau}^{2}=0.0 ; \mathrm{Chi}^{2}=0.09, \mathrm{df}=\mathrm{I}(\mathrm{P}=0.76) ; \mathrm{I}^{2}=0.0 \%$

Test for overall effect: $Z=9.21(P<0.0000 I)$

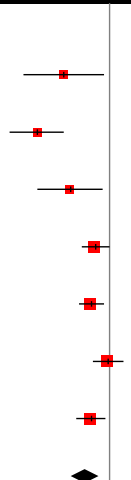

$5.6 \%$

$10.1 \%$

$7.7 \%$

$19.7 \%$

$20.2 \%$

$17.8 \%$

$19.0 \%$

$100.0 \%$

$38.4 \%$

$61.6 \%$

$100.0 \%$
$0.47[0.24,0.92]$

$0.30[0.19,0.47]$

$0.52[0.30,0.90]$

$0.79[0.63,0.99]$

$0.74[0.60,0.92]$

$0.97[0.75,1.26]$

$0.74[0.58,0.94]$

0.66 [ $0.52,0.83$ ]

$0.66[0.50,0.87]$

$0.69[0.63,0.75]$

$\checkmark$

$0.69[0.63,0.74]$

$\begin{array}{lllllll}0.1 & 0.2 & 0.5 & 1 & 2 & 5 & 10\end{array}$

Favours intervention Favours control 
Analysis 27.3. Comparison 27 Water quality intervention versus control for RCTs: by methodological quality (odds ratios), Outcome 3 Diarrhoea: by follow up.

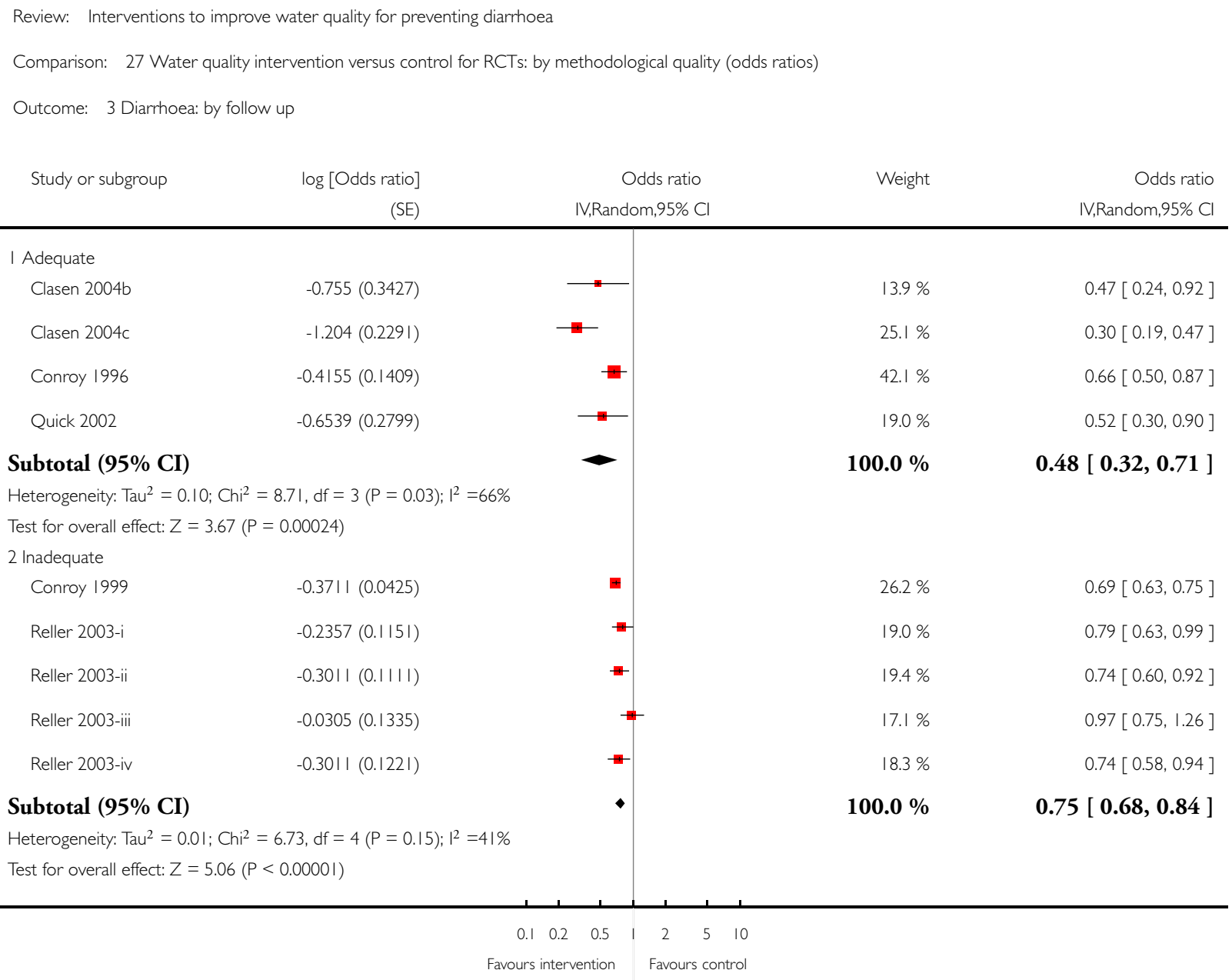


Analysis 27.4. Comparison 27 Water quality intervention versus control for RCTs: by methodological quality (odds ratios), Outcome 4 Diarrhoea: by blinding.

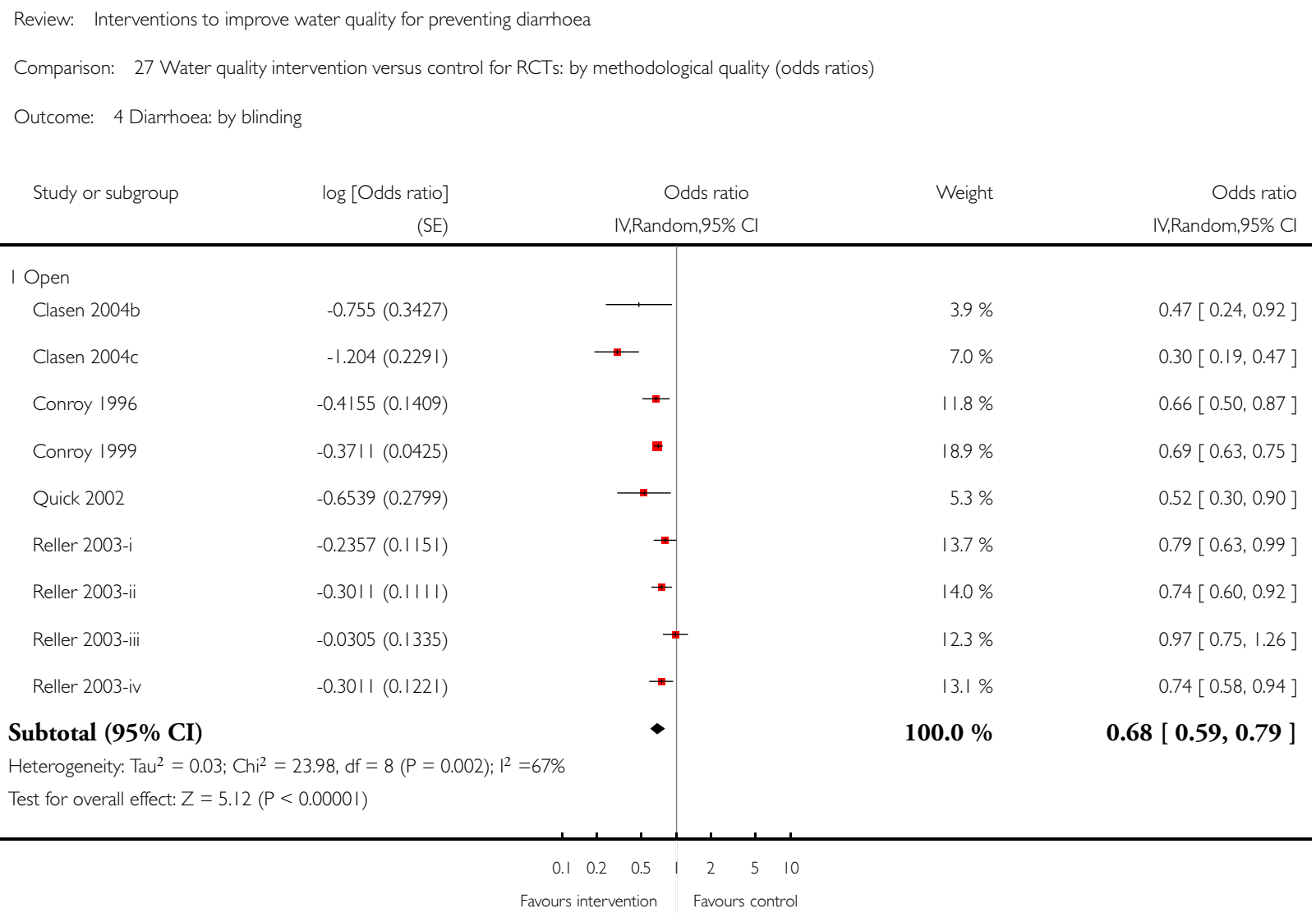


Analysis 28.I. Comparison 28 Water quality intervention versus control for quasi-RCTs: by methodological quality (rate ratios), Outcome I Diarrhoea: by comparability of characteristics.

Review: Interventions to improve water quality for preventing diarrhoea

Comparison: 28 Water quality intervention versus control for quasi-RCTs: by methodological quality (rate ratios)

Outcome: I Diarrhoea: by comparability of characteristics

Study or subgroup $\quad \log$ [Rate ratio] Rate ratio Reight

(SE) IV,Random,95\% Cl
IV,Random,95\% Cl

$\begin{array}{ll}\text { I Adequate } & \\ \text { Alam 1989 } & -0.1863(0.0795) \\ \text { Aziz 1990 } & -0.2877(0.0329) \\ \text { Luby 2004a-i } & -0.5108(0.1717) \\ \text { Luby 2004a-ii } & -1.204(0.2806)\end{array}$

Subtotal $(95 \% \mathrm{CI})$

Heterogeneity: Tau $^{2}=0.03 ; \mathrm{Chi}^{2}=13.97, \mathrm{df}=3(\mathrm{P}=0.003) ; \mathrm{I}^{2}=79 \%$

Test for overall effect: $Z=3.64(P=0.00027)$

2 Unclear

Gasana 2002

$0(0.0578)$

Rate ratio $95 \%$

$0.83[0.71,0.97]$

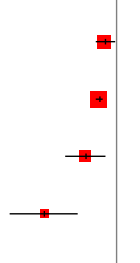

$31.6 \%$

$0.75[0.70,0.80]$

$36.0 \%$

$0.60[0.43,0.84]$

$20.6 \%$

$0.30[0.17,0.52]$

Subtotal (95\% CI)

Heterogeneity: not applicable

Test for overall effect: $Z=0.0(P=1.0)$

3 Inadequate

Jensen 2003

Subtotal $(95 \% \mathrm{CI})$

Heterogeneity: not applicable

Test for overall effect: $Z=0.48(P=0.63)$

$100.0 \%$

$100.0 \%$

$100.0 \%$

$100.0 \%$
$1.00[0.89,1.12]$

$1.00[0.89,1.12]$

$0.94[0.73,1.21]$

$0.94[0.73,1.21]$

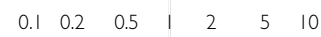

Favours intervention Favours control 
Analysis 28.2. Comparison 28 Water quality intervention versus control for quasi-RCTs: by methodological quality (rate ratios), Outcome 2 Diarrhoea: by contemporaneous of data collection.

Review: Interventions to improve water quality for preventing diarrhoea

Comparison: 28 Water quality intervention versus control for quasi-RCTs: by methodological quality (rate ratios)

Outcome: 2 Diarrhoea: by contemporaneous of data collection

Study or subgroup log [Rate ratio] Rate ratio Reight

(SE) IV,Random,95\% Cl IV,Random,95\% Cl

$\begin{array}{ll}\text { I Adequate } & \\ \text { Alam 1989 } & -0.1863(0.0795) \\ \text { Aziz 1990 } & -0.2877(0.0329) \\ \text { Garrett 2004 } & -0.821(0.2295) \\ \text { Jensen 2003 } & -0.0619(0.1288) \\ \text { Luby 2004a-i } & -0.5108(0.1717) \\ \text { Luby 2004a-ii } & -1.204(0.2806) \\ \text { Mahfouz 1995 } & -0.5978(0.305) \\ \text { Messou 1997 } & -0.5798(0.2069) \\ \text { Quick 2002 } & -0.6539(0.2799) \\ \text { Xiao 1997 } & -0.7985(0.0222)\end{array}$

Subtotal $(95 \% \mathrm{CI})$

Heterogeneity: Tau $^{2}=0.12 ; \mathrm{Chi}^{2}=220.27, \mathrm{df}=9(\mathrm{P}<0.0000 \mathrm{I}) ; \mathrm{I}^{2}=96 \%$

Test for overall effect: $Z=4.31(P=0.000016)$

2 Unclear

Gasana 2002

$0(0.0578)$

-

Subtotal (95\% CI)

Heterogeneity: not applicable

Test for overall effect: $Z=0.0(P=1.0)$

\begin{tabular}{|c|c|c|}
\hline 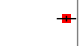 & $11.9 \%$ & $0.83[0.71,0.97]$ \\
\hline - & $12.3 \%$ & $0.75[0.70,0.80]$ \\
\hline 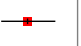 & $9.1 \%$ & $0.44[0.28,0.69]$ \\
\hline$\rightarrow$ & $11.1 \%$ & $0.94[0.73,1.21]$ \\
\hline$\rightarrow$ & $10.3 \%$ & $0.60[0.43,0.84]$ \\
\hline 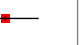 & $8.0 \%$ & $0.30[0.17,0.52]$ \\
\hline$\longrightarrow$ & $7.5 \%$ & $0.55[0.30,1.00]$ \\
\hline$\rightarrow$ & $9.5 \%$ & $0.56[0.37,0.84]$ \\
\hline$\longrightarrow$ & $8.0 \%$ & $0.52[0.30,0.90]$ \\
\hline $\mathbf{- 1}$ & $12.3 \%$ & $0.45[0.43,0.47]$ \\
\hline$<$ & $100.0 \%$ & $0.59[0.46,0.75]$ \\
\hline & $100.0 \%$ & $1.00[0.89,1.12]$ \\
\hline 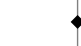 & $100.0 \%$ & $1.00[0.89,1.12]$ \\
\hline
\end{tabular}

$\begin{array}{lllllll}0.1 & 0.2 & 0.5 & 1 & 2 & 5 & 10\end{array}$

Favours intervention Favours control 
Analysis 29.1. Comparison 29 Water quality intervention versus control for quasi-RCTs: by methodological quality (risk ratios), Outcome I Diarrhoea: by comparability of characteristics.

Review: Interventions to improve water quality for preventing diarrhoea

Comparison: 29 Water quality intervention versus control for quasi-RCTs: by methodological quality (risk ratios)

Outcome: I Diarrhoea: by comparability of characteristics

Study or subgroup $\quad \log [$ Risk ratio $] \quad$ Risk ratio Reight

(SE) IV,Random,95\% Cl IV,Random,95\% Cl

I Adequate

Mahfouz 1995

$-0.5978(0.305)$

Xiao 1997

$-0.7985(0.0222)$

Subtotal (95\% CI)

Heterogeneity: Tau $^{2}=0.0 ; \mathrm{Chi}^{2}=0.43, \mathrm{df}=\mathrm{I}(\mathrm{P}=0.5 \mathrm{I}) ; \mathrm{I}^{2}=0.0 \%$

Test for overall effect: $Z=36.02(P<0.0000 I)$

2 Inadequate

Garrett 2004

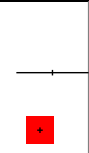

$+$

Subtotal (95\% CI)

Heterogeneity: not applicable

Test for overall effect: $Z=3.58(P=0.00035)$ $0.55[0.30,1.00]$

$\begin{array}{rr}0.5 \% & 0.55[0.30,1.00] \\ 99.5 \% & 0.45[0.43,0.47] \\ \mathbf{1 0 0 . 0} \% & \mathbf{0 . 4 5}[\mathbf{0 . 4 3}, \mathbf{0 . 4 7}] \\ & \\ 100.0 \% & 0.44[0.28,0.69]\end{array}$

$100.0 \%$

Favours intervention 
Analysis 29.2. Comparison 29 Water quality intervention versus control for quasi-RCTs: by methodological quality (risk ratios), Outcome 2 Diarrhoea: by contemporaneous of data collection.

Review: Interventions to improve water quality for preventing diarrhoea

Comparison: 29 Water quality intervention versus control for quasi-RCTs: by methodological quality (risk ratios)

Outcome: 2 Diarrhoea: by contemporaneous of data collection

Study or subgroup log [Risk ratio] Risk ratio Reight

(SE) IV,Random,95\% Cl

IV,Random,95\% Cl

I Adequate

Alam 1989

$-0.1863(0.0795)$

(

Aziz 1990

$-0.2877(0.0329)$

Garrett 2004

$-0.821(0.2295)$

Jensen 2003

$-0.0619(0.1288)$

Luby 2004a-i

$-0.5108(0.1717)$

Luby 2004a-ii

$-1.204(0.2806)$

Mahfouz 1995

$-0.5978(0.305)$

Messou 1997

$-0.5798(0.2069)$

Quick 2002

$-0.6539(0.2799)$

Xiao 1997

$-0.7985(0.0222)$

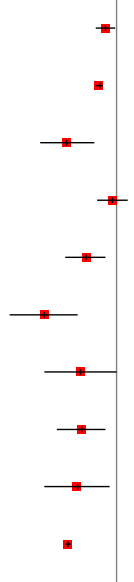

$11.9 \%$

$0.83[0.71,0.97]$

$12.3 \%$

$0.75[0.70,0.80]$

$9.1 \%$

$0.44[0.28,0.69]$

Subtotal $(\mathbf{9 5 \%} \mathrm{CI})$

Heterogeneity: $\mathrm{Tau}^{2}=0.12 ; \mathrm{Chi}^{2}=220.27, \mathrm{df}=9(\mathrm{P}<0.0000 \mathrm{I}) ; \mathrm{I}^{2}=96 \%$

Test for overall effect: $Z=4.31(P=0.000016)$

2 Unclear

Gasana 2002

Subtotal $(95 \% \mathrm{CI})$

Heterogeneity: not applicable

Test for overall effect: $Z=0.0(P=1.0)$ 
A P P E N D I CES

Appendix I. Search methods: detailed search strategies

\begin{tabular}{|c|c|c|c|c|c|}
\hline Search set & CIDG $\mathbf{S R}^{a}$ & CENTRAL & MEDLINE $^{b}$ & EMBASE $^{b}$ & LILACS $^{b}$ \\
\hline 1 & water & $\begin{array}{l}\text { WATER PURIFICA- } \\
\text { TION }\end{array}$ & $\begin{array}{l}\text { WATER PURIFICA- } \\
\text { TION }\end{array}$ & $\begin{array}{l}\text { WATER PURIFICA- } \\
\text { TION }\end{array}$ & water \\
\hline 2 & $\begin{array}{l}\text { purification OR treat- } \\
\text { ment OR chlorina- } \\
\text { tion OR decontami- } \\
\text { nation OR filtration } \\
\text { OR supply OR stor- } \\
\text { age OR consumption }\end{array}$ & $\begin{array}{l}\text { WATER MICROBI- } \\
\text { OLOGY }\end{array}$ & $\begin{array}{l}\text { WATER MICROBI- } \\
\text { OLOGY }\end{array}$ & $\begin{array}{l}\text { WATER MICROBI- } \\
\text { OLOGY }\end{array}$ & $\begin{array}{l}\text { purification OR treat- } \\
\text { ment OR chlorina- } \\
\text { tion OR decontami- } \\
\text { nation OR filtration } \\
\text { OR supply OR stor- } \\
\text { age OR consumption }\end{array}$ \\
\hline 3 & diarrhea & 1 OR 2 & 1 OR 2 & 1 OR 2 & diarrhea \\
\hline 4 & 1 AND 2 AND 3 & water & water & water & 1 AND 2 AND 3 \\
\hline 5 & - & $\begin{array}{l}\text { purification OR treat- } \\
\text { ment OR chlorina- } \\
\text { tion OR decontami- } \\
\text { nation OR filtration } \\
\text { OR supply OR stor- } \\
\text { age OR consumption } \\
\text { OR drink* }\end{array}$ & $\begin{array}{l}\text { purification OR treat- } \\
\text { ment OR chlorina- } \\
\text { tion OR decontami- } \\
\text { nation OR filtration } \\
\text { OR supply OR stor- } \\
\text { age OR consumption } \\
\text { OR drink* }\end{array}$ & $\begin{array}{l}\text { purification OR treat- } \\
\text { ment OR chlorina- } \\
\text { tion OR decontami- } \\
\text { nation OR filtration } \\
\text { OR supply OR stor- } \\
\text { age OR consumption } \\
\text { OR drink\$ }\end{array}$ & - \\
\hline 6 & - & 4 AND 5 & 4 AND 5 & 4 AND 5 & - \\
\hline 7 & - & 3 OR 6 & 3 OR 6 & 3 OR 6 & - \\
\hline 8 & - & $\begin{array}{l}\text { DIARRHEA/ } \\
\text { EPIDEMIOLOGY }\end{array}$ & $\begin{array}{l}\text { DIARRHEA/ } \\
\text { EPIDEMIOLOGY }\end{array}$ & $\begin{array}{l}\text { DIARRHEA/ } \\
\text { EPIDEMIOLOGY }\end{array}$ & - \\
\hline 9 & - & $\begin{array}{l}\text { DIARRHEA/ } \\
\text { MICROBIOLOGY }\end{array}$ & $\begin{array}{l}\text { DIARRHEA/ } \\
\text { MICROBIOLOGY }\end{array}$ & $\begin{array}{l}\text { DIARRHEA/ } \\
\text { PREVENTION }\end{array}$ & - \\
\hline 10 & - & $\begin{array}{l}\text { DIARRHEA/ } \\
\text { PREVENTION } \\
\text { AND CONTROL }\end{array}$ & $\begin{array}{l}\text { DIARRHEA/ } \\
\text { PREVENTION } \\
\text { AND CONTROL }\end{array}$ & $\begin{array}{l}\text { waterborne } \\
\text { infection } \$\end{array}$ & - \\
\hline 11 & - & waterborne infection* & waterborne infection* & $\begin{array}{l}\text { cholera OR shigell\$ } \\
\text { OR } \\
\text { dysenter\$ OR cryp- } \\
\text { tosporidi\$ OR giar- } \\
\text { dia } \$ \text { OR Escherichia } \\
\text { coli OR clostridium }\end{array}$ & - \\
\hline 12 & - & $\begin{array}{l}\text { INTESTINAL DIS- } \\
\text { EASES }\end{array}$ & $\begin{array}{l}\text { INTESTINAL DIS- } \\
\text { EASES }\end{array}$ & $\begin{array}{l}\text { ENTEROBACTE- } \\
\text { RIACEAE }\end{array}$ & - \\
\hline
\end{tabular}

Interventions to improve water quality for preventing diarrhoea (Review)

Copyright () 2009 The Cochrane Collaboration. Published by John Wiley \& Sons, Ltd. 


\begin{tabular}{|c|c|c|c|c|c|}
\hline 13 & - & $\begin{array}{l}\text { cholera OR shigell* } \\
\text { OR dysenter* OR } \\
\text { cryptosporidi* OR gi- } \\
\text { ardia* OR Escherichia } \\
\text { coli OR clostridium }\end{array}$ & $\begin{array}{l}\text { cholera OR shigell* } \\
\text { OR dysenter* OR } \\
\text { cryptosporidi* OR gi- } \\
\text { ardia* OR Escherichia } \\
\text { coli OR clostridium }\end{array}$ & $8-12 / \mathrm{OR}$ & - \\
\hline 14 & - & $\begin{array}{l}\text { ENTEROBACTE- } \\
\text { RIACEAE }\end{array}$ & $\begin{array}{l}\text { ENTEROBACTE- } \\
\text { RIACEAE }\end{array}$ & 7 AND 13 & - \\
\hline 15 & - & $8-14 / \mathrm{OR}$ & $8-14 / \mathrm{OR}$ & $\begin{array}{l}\text { LIMIT } 14 \text { TO HU- } \\
\text { MAN }\end{array}$ & - \\
\hline 16 & - & 7 AND 15 & 7 AND 15 & - & - \\
\hline 17 & - & - & $\begin{array}{l}\text { LIMIT } 16 \text { TO HU- } \\
\text { MAN }\end{array}$ & - & - \\
\hline
\end{tabular}

${ }^{a}$ Cochrane Infectious Diseases Group Specialized Register.

${ }^{b}$ Search terms used in combination with the search strategy for retrieving trials developed by The Cochrane Collaboration (Higgins 2005b); upper case: MeSH or EMTREE heading; lower case: free text term.

\section{Appendix 2. Data extracted from included studies}

\begin{tabular}{|c|c|}
\hline Type & Fields \\
\hline \multirow[t]{5}{*}{ Trial data } & Country and setting (urban, rural) \\
\hline & Number of participants/groups \\
\hline & $\begin{array}{l}\text { Unit of randomization, and whether measurement of effect adjusts for clustering where randomization } \\
\text { is other than individual }\end{array}$ \\
\hline & Definition and practices of control group \\
\hline & $\begin{array}{l}\text { Type and details of water quality intervention (filtration, flocculation, chemical disinfection, heat, or } \\
\text { ultraviolet (UV) radiation) }\end{array}$ \\
\hline
\end{tabular}

Other components of intervention (hygiene message, improved supply, improved sanitation, improved storage)

Whether water protected to point of use (ie by pipe, residual disinfection, or safe storage)

Case definition of diarrhoea

Method for diarrhoea assessment (self-reported, observed, or clinically confirmed) 
Where self reported, recall period used

Publication status

Prescribed criteria of methodological quality

Individual characteristics Age group

Type of water source

Level of faecal contamination of control water (low $(<100$ thermotolerant coliforms (TTC)/100 mL), medium (100 to $1000 \mathrm{TTC} / 100 \mathrm{~mL})$, and high $(>1000 \mathrm{TTC} / 100 \mathrm{~mL})$

Causative agents identified (yes or no)

Water collection, storage, and drawing practices

Distance to and other constraints regarding water supply

Sanitation facilities (improved or unimproved)

Hygiene practices

Outcomes

Pre- and post-intervention faecal contamination of drinking water, and method of assessment (including indicator used)

Diarrhoea morbidity and $95 \%$ confidence interval for each age group reported

Manner of measuring diarrhoea morbidity

Mortality attributed to diarrhoea

Rate of utilization of intervention and manner of assessing same

\section{Appendix 3. Primary drinking supply and sanitation facilities (used as control)}

\begin{tabular}{|c|c|c|c|c|c|c|}
\hline Trial & Description & Source $^{a}$ & $\begin{array}{l}\text { Access to source } \\
b\end{array}$ & $\begin{array}{l}\text { Quantity avail- } \\
\text { able }^{c}\end{array}$ & $\begin{array}{l}\text { Ambient } \mathrm{H}_{2} \mathrm{O} \\
\text { quality }\end{array}$ & Sanitation $^{d}$ \\
\hline Alam 1989 & $\begin{array}{l}\text { Shallow, hand- } \\
\text { dug wells; some } \\
\text { hand pumps }\end{array}$ & Unimproved & Unclear & Unclear & Not tested & Unclear \\
\hline
\end{tabular}


(Continued)

\begin{tabular}{|c|c|c|c|c|c|c|}
\hline Austin 1993 & Open wells & Unimproved & Sufficient & Unclear & $\begin{array}{l}\text { Mean } 1871 \mathrm{FC} / \\
100 \mathrm{~mL} \text { in wells; } \\
\text { among stored } \\
\text { water samples, } \\
\text { mean } 3358 \mathrm{FC} / \\
100 \mathrm{~mL} \text { in rainy } \\
\text { season, } 1014 \\
\mathrm{FC} / 100 \mathrm{~mL} \text { in } \\
\text { dry season }\end{array}$ & Unclear \\
\hline Aziz 1990 & $\begin{array}{l}\text { Fewer } \\
\text { hand pumps and } \\
\text { latrines; no hy- } \\
\text { giene instruction }\end{array}$ & Unimproved & Unclear & Unclear & Not tested & Unimproved \\
\hline Chiller 2004 & $\begin{array}{l}\text { Rivers, springs, } \\
\text { taps, and wells }\end{array}$ & Unclear & Unclear & Sufficient & $\begin{array}{l}98 \% \\
\text { of source samples } \\
\text { contained E. coli; } \\
\text { precise level not } \\
\text { reported }\end{array}$ & $\begin{array}{l}\text { Mostly } \\
\text { unimproved }\end{array}$ \\
\hline Clasen 2004b & $\begin{array}{l}80 \% \text { yard } \\
\text { taps supplied by } \\
\text { untreated surface } \\
\text { source, } 20 \% \text { di- } \\
\text { rectly from } \\
\text { untreated surface } \\
\text { sources }\end{array}$ & $\begin{array}{l}80 \% \text { improved, } \\
20 \% \\
\text { unimproved }\end{array}$ & Sufficient & Sufficient & $\begin{array}{l}\text { Base- } \\
\text { line mean ther- } \\
\text { motolerant col- } \\
\text { iform count of } \\
145 / 100 \mathrm{~mL} \text { at } \\
\text { taps and } 52 / 100 \\
\mathrm{~mL} \text { at surface } \\
\text { sources }\end{array}$ & Unimproved \\
\hline Clasen $2004 \mathrm{c}$ & $\begin{array}{l}\text { Irrigation canals } \\
\text { and other surface } \\
\text { sources }\end{array}$ & Unimproved & Sufficient & Sufficient & $\begin{array}{l}\text { Base- } \\
\text { line mean ther- } \\
\text { motolerant col- } \\
\text { iform count of } \\
793 / 100 \mathrm{~mL}\end{array}$ & Unimproved \\
\hline Colford 2002 & $\begin{array}{l}\text { Household } \\
\text { taps supplied by } \\
\text { municipal water } \\
\text { treatment }\end{array}$ & Improved & Sufficient & Sufficient & $\begin{array}{l}\text { Data from water } \\
\text { treatment plant: } \\
\text { met US fed- } \\
\text { eral and Califor- } \\
\text { nia drinking wa- } \\
\text { ter standards }\end{array}$ & Improved \\
\hline Conroy 1996 & $\begin{array}{l}\text { Open } \\
\text { water holes, tank } \\
\text { fed by untreated } \\
\text { piped water sup- } \\
\text { ply; control } \\
\text { households pro- }\end{array}$ & Unimproved & Unclear & Unclear & $\begin{array}{l}\text { All water sources } \\
\text { positive for FC; } \\
\text { some counts > } \\
103 \text { colony- } \\
\text { forming units } \\
(\mathrm{CFU}) / \mathrm{mL}\end{array}$ & Unclear \\
\hline
\end{tabular}

Interventions to improve water quality for preventing diarrhoea (Review)

Copyright () 2009 The Cochrane Collaboration. Published by John Wiley \& Sons, Ltd. 


\begin{tabular}{|c|c|c|c|c|c|c|}
\hline & $\begin{array}{l}\text { vided same bot- } \\
\text { tles, but were in- } \\
\text { structed to keep } \\
\text { them indoors }\end{array}$ & & & & & \\
\hline Conroy 1999 & $\begin{array}{l}\text { Open } \\
\text { water holes, tank } \\
\text { fed by untreated } \\
\text { piped water sup- } \\
\text { ply; control } \\
\text { households pro- } \\
\text { vided same bot- } \\
\text { tles, but were in- } \\
\text { structed to keep } \\
\text { them indoors }\end{array}$ & Unimproved & Unclear & Unclear & Not tested & Unclear \\
\hline Crump 2004 & $\begin{array}{l}50 \% \text { ponds, } \\
49 \% \text { rivers }\end{array}$ & Unimproved & Unclear & Insufficient & $\begin{array}{l}\text { Baseline mean } E \text {. } \\
\text { coli level was } 98 / \\
100 \mathrm{~mL}\end{array}$ & $\begin{array}{l}\text { Unclear; } \\
33 \% \text { defecate on } \\
\text { ground }\end{array}$ \\
\hline Doocy 2004 & $\begin{array}{l}\text { Surface } \\
\text { sources and some } \\
\text { tap stands }\end{array}$ & Unimproved & Unclear & Insufficient & $\begin{array}{l}\text { Qualitative mea- } \\
\text { sure only }\end{array}$ & Improved \\
\hline du Preez 2004 & Protected wells & Improved & Sufficient & Unclear & $\begin{array}{l}\text { Samples with } E \text {. } \\
\text { coli per } 100 \mathrm{~mL} \text { : } \\
31<10 ; 9>10 \\
<100 ; 1>100< \\
1000 ; 3>1000\end{array}$ & Improved \\
\hline Garrett 2004 & Unclear & Unclear & Unclear & Sufficient & Not tested & Unimproved \\
\hline Gasana 2002 & Spring & Unimproved & Unclear & Unclear & $\begin{array}{l}\text { Baseline sample } \\
\text { range from } 4 \text { to } \\
1100 \text { total col- } \\
\text { iforms } / 100 \mathrm{~mL}\end{array}$ & Unimproved \\
\hline Handzel 1998 & $\begin{array}{l}48 \% \\
\text { tap, } 52 \% \text { tube- } \\
\text { well; } 61 \% \text { paid } \\
\text { for drinking wa- } \\
\text { ter }\end{array}$ & Improved & Sufficient & Sufficient & $\begin{array}{l}\text { Baseline geomet- } \\
\text { ric mean FC } \\
\text { counts/100 mL: } \\
\text { tap water }-138 \\
\text { at source, } 280 \\
\text { stored in home; } \\
\text { tubewell water - } \\
6 . \\
7 \text { at source, } 138 \\
\text { stored in home }\end{array}$ & \\
\hline
\end{tabular}


(Continued)

\begin{tabular}{|c|c|c|c|c|c|c|}
\hline Jensen 2003 & $\begin{array}{l}\text { Some slow sand } \\
\text { filters in poor } \\
\text { condition; some } \\
\text { house- } \\
\text { hold taps; major- } \\
\text { ity used ground } \\
\text { water }\end{array}$ & Improved & Unclear & Unclear & $\begin{array}{l}\text { Baseline (pre-in- } \\
\text { tervention) geo- } \\
\text { metric mean in } \\
\text { intervention vil- } \\
\text { lage was } 13.3 \mathrm{E} \text {. } \\
\text { coli CFU/ } \\
100 \mathrm{~mL} \text {; geomet- } \\
\text { ric mean E. coli } \\
\text { count of } 137 / \\
100 \mathrm{~mL} \text { in con- } \\
\text { trol village }\end{array}$ & Unclear \\
\hline Kirchhoff 1985 & $\begin{array}{l}\text { Pond wa- } \\
\text { ter stored in clay } \\
\text { pots after filter- } \\
\text { ing with cloth }\end{array}$ & Unimproved & Unclear & Insufficient & $\begin{array}{l}\text { Mean of } 970 \mathrm{FC} / \\
100 \\
\mathrm{~mL} \text { from pond } \\
\text { sources; } 16,000 \\
\text { in control stored } \\
\text { water }\end{array}$ & Unimproved \\
\hline Luby 2004 & $\begin{array}{l}\text { Tanker trucks, } \\
\text { shared municipal } \\
\text { taps }\end{array}$ & Unimproved & Unclear & Unclear & $\begin{array}{l}\text { At baseline, } 79 \% \\
\text { of participating } \\
\text { stored household } \\
\text { samples were free } \\
\text { of E. coli }\end{array}$ & Improved \\
\hline Luby $2004 a$ & Unclear & $75 \%$ improved & Sufficient & Unclear & Not tested & Improved \\
\hline Lule 2005 & $\begin{array}{l}16 \% \text { surface } \\
\text { or shallow wells, } \\
50 \% \text { protected } \\
\text { springs, } \quad 49 \% \\
\text { boreholes or taps }\end{array}$ & Unimproved & Sufficient & Sufficient & $\begin{array}{l}\text { Baseline mean } E \text {. } \\
\text { coli counts: } 11 \text { at } \\
\text { source, } \\
163 \text { stored water; } \\
54 \% \text { of source } \\
\text { water had some } \\
\text { contamina- } \\
\text { tion, compared } \\
\text { to } 89 \% \text { of stored } \\
\text { water }\end{array}$ & Improved \\
\hline Mahfouz 1995 & Shallow wells & Unimproved & Unclear & Unclear & $\begin{array}{l}92.3 \% \\
\text { positive with } E \text {. } \\
\text { coli; amount not } \\
\text { recorded }\end{array}$ & Improved \\
\hline Messou 1997 & Not reported & Unimproved & Unclear & Unclear & Not tested & Unclear \\
\hline Quick 1999 & $\begin{array}{l}\text { Shallow uncov- } \\
\text { ered wells; } 38 \% \\
\text { treated water }\end{array}$ & Unimproved & Unclear & Unclear & $\begin{array}{l}\text { Baseline median } \\
\text { colony count of } \\
\text { E. coli: } 57050 / \\
100 \mathrm{~mL} \text { for }\end{array}$ & $\begin{array}{l}\text { Unim- } \\
\text { proved (but 47\% } \\
\text { used latrine) }\end{array}$ \\
\hline
\end{tabular}

Interventions to improve water quality for preventing diarrhoea (Review) 


\begin{tabular}{|c|c|c|c|c|c|c|}
\hline & & & & & $\begin{array}{l}\text { source water and } \\
46950 / 100 \mathrm{~mL} \\
\text { for stored water }\end{array}$ & \\
\hline Quick 2002 & $\begin{array}{l}\text { Shallow wells; } \\
\text { some boiling }\end{array}$ & Unimproved & Unclear & Unclear & $\begin{array}{l}\text { Baseline median } \\
\text { colony count of } \\
E \text {. } \\
\text { coli: } 34 / 100 \mathrm{~mL} \\
\text { for source water } \\
\text { and } 44 / 100 \mathrm{~mL} \\
\text { for stored water }\end{array}$ & Unclear \\
\hline Reller 2003 & $\begin{array}{l}\text { Surface wa- } \\
\text { ter from shallow } \\
\text { wells, rivers and } \\
\text { springs }\end{array}$ & Unimproved & Unclear & Unclear & $\begin{array}{l}\text { Baseline median } \\
\text { colony count of } \\
\text { E. coli: } 63 / 100 \\
\mathrm{~mL}\end{array}$ & Unclear \\
\hline Roberts 2001 & $\begin{array}{l}\text { Traditional pots } \\
\text { or standard ra- } \\
\text { tion buckets } \\
\text { filled } \\
\text { at refugee camp } \\
\text { water point }\end{array}$ & Improved & Unclear & Unclear & $\begin{array}{l}\text { At well, } 71 \% \text { of } \\
\text { samples were } 1 \\
\text { FC/ } 100 \mathrm{~mL} \text { or } \\
\text { less; } 100 \%<100 \\
\mathrm{FC} / 100 \mathrm{~mL}\end{array}$ & Unclear \\
\hline Semenza 1998 & $\begin{array}{l}\text { Households } \\
\text { with- } \\
\text { out piped water } \\
\text { (procured from } \\
\text { street tap, neigh- } \\
\text { bour tap, well, } \\
\text { vendor, or river) }\end{array}$ & Unimproved & Unclear & Unclear & $\begin{array}{l}\text { Base- } \\
\text { line mean } 49 \text { fae- } \\
\text { cal coliform } / 100 \\
\mathrm{~mL}\end{array}$ & Unclear \\
\hline Torun 1982 & $\begin{array}{l}\text { Shallow, unpro- } \\
\text { tected, hand-dug } \\
\text { wells }\end{array}$ & Unimproved & Unclear & Unclear & $\begin{array}{l}3 \% \text { of } 698 \text { sam- } \\
\text { ples from control } \\
\text { village had col- } \\
\text { iform bacteria }\end{array}$ & Unimproved \\
\hline URL 1995 & $\begin{array}{l}\text { House- } \\
\text { hold tap }(27 \%) \text {, } \\
\text { public tap }(21 \%) \\
\text {, well }(23 \%)\end{array}$ & Improved & Unclear & Unclear & $\begin{array}{l}\text { Range } 5 \text { to } 260 \\
\text { FC/ } 100 \mathrm{~mL} \text { de- } \\
\text { pending on site }\end{array}$ & Improved \\
\hline Xiao 1997 & Not reported & Unimproved & Unclear & Unclear & Not tested & Unclear \\
\hline
\end{tabular}

E. coli: Escherichia coli; FC: faecal coliform.

a'Improved' includes household connection, public standpipe, borehole, protected dug well, protected spring, rainwater collection; 'unimproved' includes unprotected well, unprotected spring, vendor-provided water, bottled water; and 'unclear' means unclear or not reported; definition based on WHO 2000. 
${ }^{b}$ 'Sufficient' means located within $500 \mathrm{~m}$, queuing no more than 15 minutes, no more than 3 minutes to fill $20 \mathrm{~L}$ container, and maintained so available consistently; 'insufficient' means that it does not meet any of above; and 'unclear' means unclear or not reported; definition based minimum standards established by The Sphere Project 2004.

c'Sufficient' means a minimum of $15 \mathrm{~L} /$ day/person; 'insufficient' means less than $15 \mathrm{~L} /$ day/person; and 'unclear' means unclear or not reported; definition based on minimum standards established by The Sphere Project 2004.

d'Improved' means connection to a public sewer or septic system, pour flush latrine, simple pit latrine, or ventilated improved pit latrine; 'unimproved' means service or bucket latrine, public latrines, open latrines; and 'unclear' means unclear or not reported; definition based on WHO 2000.

\section{Appendix 4. Interventions}

\begin{tabular}{|c|c|c|c|c|}
\hline Trial & Description & Source or household & Compliance measured? & Other components \\
\hline Alam 1989 & Improved water supply & Source & Not reported & Hygiene education \\
\hline Austin 1993-i & $\begin{array}{l}\text { Household chlorination } \\
\text { among children ages } 25 \text { to } \\
60 \text { months }\end{array}$ & Household & $\begin{array}{l}60 \% \text { compliance measured } \\
\text { by residual chlorine }\end{array}$ & None \\
\hline Austin 1993-ii & $\begin{array}{l}\text { Household chlorina- } \\
\text { tion among children ages } 6 \\
\text { to } 24 \text { months }\end{array}$ & Household & $\begin{array}{l}68 \% \text { compliance measured } \\
\text { by residual chlorine }\end{array}$ & None \\
\hline Aziz 1990 & Improved water supply & Source & $\begin{array}{l}\text { Periodic cross-sectional as- } \\
\text { sessments; rate not reported }\end{array}$ & $\begin{array}{l}\text { Improved sanitation, } \\
\text { hygiene education }\end{array}$ \\
\hline Chiller 2004 & $\begin{array}{l}\text { Flocculant-disinfectant sa- } \\
\text { chets used at household } \\
\text { level }\end{array}$ & Household & $\begin{array}{l}85 \% \text { compliance measured } \\
\text { by residual chlorine }\end{array}$ & Hygiene education \\
\hline Clasen 2004b & Household ceramic filters & Household & Not reported & $\begin{array}{l}\text { Filter included improved } \\
\text { storage }\end{array}$ \\
\hline Clasen $2004 \mathrm{c}$ & Household ceramic filters & Household & Not reported & $\begin{array}{l}\text { Filter included improved } \\
\text { storage }\end{array}$ \\
\hline Colford 2002 & $\begin{array}{l}\text { Household reverse osmosis } \\
\text { filters }\end{array}$ & Household & Plumbed-in unit & None \\
\hline Conroy 1996 & $\begin{array}{l}\text { Solar disinfection in plastic } \\
\text { bottles at household level }\end{array}$ & Household & $\begin{array}{l}\text { Random checks by project } \\
\text { workers; rate not reported }\end{array}$ & None \\
\hline Conroy 1999 & $\begin{array}{l}\text { Solar disinfection in plastic } \\
\text { bottles at household level }\end{array}$ & Household & Not reported & None \\
\hline Crump 2004-i & $\begin{array}{l}\text { Sodium hypochlorite used } \\
\text { at household level }\end{array}$ & Household & $\begin{array}{l}85 \% \text { compliance (mea- } \\
\text { sured by residual chlorine) at } \\
\text { scheduled visits; } 61 \% \text { during } \\
\text { unannounced weekly visits }\end{array}$ & Hygiene education \\
\hline
\end{tabular}

Interventions to improve water quality for preventing diarrhoea (Review)

Copyright @ 2009 The Cochrane Collaboration. Published by John Wiley \& Sons, Ltd. 
(Continued)

\begin{tabular}{|c|c|c|c|c|}
\hline Crump 2004-ii & $\begin{array}{l}\text { Flocculent-disinfectant sa- } \\
\text { chets used at household } \\
\text { level }\end{array}$ & Household & $\begin{array}{l}86 \% \text { (measured by residual } \\
\text { chlorine) at scheduled visits; } \\
44 \% \text { during unannounced } \\
\text { weekly visits }\end{array}$ & Hygiene education \\
\hline Doocy 2004 & $\begin{array}{l}\text { Flocculant-disinfectant sa- } \\
\text { chets used at household } \\
\text { level in refugee camp }\end{array}$ & Household & $\begin{array}{l}95 \% \text { compliance based on } \\
\text { residual chlorine sampling }\end{array}$ & $\begin{array}{l}\text { Both controls and interven- } \\
\text { tion group received water } \\
\text { storage vessel }\end{array}$ \\
\hline du Preez 2004 & Household ceramic filter & Household & $100 \%$ based on observation & $\begin{array}{l}\text { Filter included improved } \\
\text { storage }\end{array}$ \\
\hline Garrett 2004 & $\begin{array}{l}\text { Household } \\
\text { chlorination using sodium } \\
\text { hypochlorite }\end{array}$ & Household & $\begin{array}{l}43 \% \text { based on residual chlo- } \\
\text { rine }\end{array}$ & $\begin{array}{l}\text { Sanitation, hygiene educa- } \\
\text { tion, storage, supply }\end{array}$ \\
\hline Gasana 2002 & $\begin{array}{l}\text { Source improvements (wa- } \\
\text { ter pipes, sedimentation } \\
\text { tank, ceramic filter, storage } \\
\text { tank, communal tap) }\end{array}$ & Source & Not reported & None \\
\hline Handzel 1998 & $\begin{array}{l}\text { Household } \\
\text { chlorination using sodium } \\
\text { hypochlorite solution and } \\
\text { special storage vessel }\end{array}$ & Household & $\begin{array}{l}90 \% \text { compliance based on } \\
\text { residual chlorine measure- } \\
\text { ments }\end{array}$ & None \\
\hline Jensen 2003 & $\begin{array}{l}\text { Village level chlorination } \\
\text { of water supply using cal- } \\
\text { cium hypochlorite }\end{array}$ & Source & $\begin{array}{l}\text { Unclear, though chlorinated } \\
\text { water was supplied through } \\
\text { distribution system to all in- } \\
\text { tervention households }\end{array}$ & None \\
\hline Kirchhoff 1985 & $\begin{array}{l}\text { Household level chlorina- } \\
\text { tion with sodium } \\
\text { hypochlorite }\end{array}$ & Household & None reported & None \\
\hline Luby $2004 a-i$ & Bleach + regular vessel & Household & None reported & $\begin{array}{l}\text { Vessel provided improved } \\
\text { storage }\end{array}$ \\
\hline Luby 2004a-ii & Bleach + insulated vessel & Household & As above & As above \\
\hline Luby 2004b-i & Dilute bleach + vessel & Household & Yes, though not yet available & $\begin{array}{l}\text { Vessel provided improved } \\
\text { storage }\end{array}$ \\
\hline Luby $2004 b-i i$ & $\begin{array}{l}\text { Flocculant-disinfectant }+ \\
\text { soap }\end{array}$ & Household & As above & Hygiene instruction \\
\hline Luby 2004b-iii & $\begin{array}{l}\text { Flocculant-disinfectant }+ \\
\text { vessel }\end{array}$ & Household & As above & $\begin{array}{l}\text { Vessel provided improved } \\
\text { storage }\end{array}$ \\
\hline
\end{tabular}

Interventions to improve water quality for preventing diarrhoea (Review)

Copyright () 2009 The Cochrane Collaboration. Published by John Wiley \& Sons, Ltd. 
(Continued)

\begin{tabular}{|c|c|c|c|c|}
\hline Lule 2005 & $\begin{array}{l}\text { Household level } \\
\text { chlorination using sodium } \\
\text { hypochlorite + special ves- } \\
\text { sel }\end{array}$ & Household & Not reported & $\begin{array}{l}\text { Vessel provided improved } \\
\text { storage; hygiene education } \\
\text { was provided to both in- } \\
\text { tervention and comparison } \\
\text { groups }\end{array}$ \\
\hline Mahfouz 1995 & $\begin{array}{l}\text { Household level } \\
\text { chlorination using calcium } \\
\text { hypochlorite }\end{array}$ & Household & $\begin{array}{l}\text { Some residual chlorine in all } \\
\text { intervention samples }\end{array}$ & None \\
\hline Messou 1997 & Improved water supply & Source & $\begin{array}{l}\text { Yes, measured increase in wa- } \\
\text { ter supplied and change in } \\
\text { sanitation and hygiene prac- } \\
\text { tices }\end{array}$ & Sanitation, oral rehydration \\
\hline Quick 1999 & $\begin{array}{l}\text { Household level chlorina- } \\
\text { tion + vessel }\end{array}$ & Household & $\begin{array}{l}70 \% \text { to } 95 \% \text { compliance } \\
\text { based on residual chlorine } \\
\text { (increased during course of } \\
\text { study) }\end{array}$ & $\begin{array}{l}\text { Improved storage, hygiene } \\
\text { education }\end{array}$ \\
\hline Quick 2002 & $\begin{array}{l}\text { Household level chlorina- } \\
\text { tion + vessel }\end{array}$ & Household & $\begin{array}{l}70 \% \text { compliance based on } \\
\text { residual chlorine }\end{array}$ & $\begin{array}{l}\text { Improved storage, hygiene } \\
\text { education }\end{array}$ \\
\hline Reller 2003-i & Flocculant-disinfectant & Household & $\begin{array}{l}\text { Residual chlorine }>0.1 \mathrm{mg} / \mathrm{L} \\
\text { in unannounced visits: } 27 \%\end{array}$ & None \\
\hline Reller 2003-ii & Bleach & As above & $\begin{array}{l}\text { Residual chlorine }>0.1 \mathrm{mg} / \mathrm{L} \\
\text { in unannounced visits: } 36 \%\end{array}$ & None \\
\hline Reller 2003-iii & Bleach + vessel & As above & $\begin{array}{l}\text { Residual chlorine }>0.1 \mathrm{mg} / \mathrm{L} \\
\text { in unannounced visits: } 44 \%\end{array}$ & Improved storage vessel \\
\hline Reller 2003-iv & $\begin{array}{l}\text { Flocculant-disinfectant }+ \\
\text { vessel }\end{array}$ & As above & $\begin{array}{l}\text { Residual chlorine }>0.1 \mathrm{mg} / \mathrm{L} \\
\text { in unannounced visits: } 34 \%\end{array}$ & As above \\
\hline Roberts 2001 & $\begin{array}{l}\text { Improved storage (bucket } \\
\text { with spout and narrow } \\
\text { opening to limit hand en- } \\
\text { try) }\end{array}$ & Household & $\begin{array}{l}\text { Intervention house- } \\
\text { holders received buckets; ac- } \\
\text { tual use was not reported }\end{array}$ & None \\
\hline Semenza 1998 & $\begin{array}{l}\text { Household level chlorina- } \\
\text { tion }\end{array}$ & Household & $\begin{array}{l}73 \% \text { based on residual chlo- } \\
\text { rine levels at time of visit }\end{array}$ & $\begin{array}{l}\text { Improved storage, hygiene } \\
\text { education }\end{array}$ \\
\hline Torun 1982 & $\begin{array}{l}\text { Source protection (spring), } \\
\text { chlorination facilities, "ad- } \\
\text { equate storage", and water } \\
\text { mains with faucets to yards } \\
\text { of intervention village }\end{array}$ & Source & No & Hygiene education \\
\hline
\end{tabular}


(Continued)

\begin{tabular}{lllll}
\hline URL 1995-i & Household ceramic filters & Household & $\begin{array}{l}87 \% \text { to } 93 \% \text { use of filter by } \\
\text { children }\end{array}$ & None \\
\hline URL 1995-ii & Household ceramic filters & As above & As above & Hygiene education \\
\hline Xiao 1997 & Improved water supply & Source & $\begin{array}{l}\text { Community intervention; Sanitation, hygiene educa- } \\
\text { use not otherwise reported }\end{array}$ \\
\hline
\end{tabular}

\section{WHAT'S NEW}

Last assessed as up-to-date: 21 January 2006.

\begin{tabular}{|c|c|c|}
\hline Date & Event & Description \\
\hline 18 August 2008 & Amended & Converted to new review format with minor editing. \\
\hline
\end{tabular}

\section{H I S T O R Y}

Protocol first published: Issue 2, 2004

Review first published: Issue 3, 2006

\section{CONTRIBUTIONS OF AUTHORS}

Conceived review: SC. Co-ordinated review: TC. Designed review: TC, IR, TR, WS. Drafted protocol: TC. Executed search strategy: TC and Cochrane Infectious Diseases Group (CIDG). Screened search results: TC, TR. Retrieved papers: TC. Applied inclusion criteria: TC, TR, SC. Extracted data: TC, TR, WS. Computed estimates of effect: TC, TR, WS. Applied quality criteria: TC, TR, IR. Contacted authors for additional information: TC. Addressed statistical issues: TC, TR, WS, CIDG. Entered data into Review Manager: TC. Drafted review: TC. Commented on review: IR, TR, WS, SC. Prepared tables: TC. Prepared figures: WS, TC. Guarantor of review: TC.

\section{DECLARATIONSOF INTEREST}

Thomas Clasen, Sandy Cairncross, Tamer Rabie, and Wolf-Peter Schmidt participate in research supported by Unilever, Ltd., which manufactures and sells household-based water treatment devices. 


\section{DIFFERENCES BETWEEN PROTOCOLANDREVIEW}

2006, Issue 3 (first version of review): Wolf-Peter Schmidt became a co-author of the review in June 2005.

\section{N DEX TERMS}

Medical Subject Headings (MeSH)

Diarrhea [ ${ }^{*}$ prevention \& control]; Randomized Controlled Trials as Topic; Water Purification [*methods; standards]; Water Supply [*standards]

\section{MeSH check words}

Adult; Child; Humans 